Florida International University FIU Digital Commons

FIU Electronic Theses and Dissertations

University Graduate School

6-2-2016

\title{
Haiti and the Heavens: Utopianism and Technocracy in the Cold War Era
}

Adam M. Silvia

Florida International University, adammsilvia@yahoo.com

DOI: $10.25148 /$ etd.FIDC000766

Follow this and additional works at: https://digitalcommons.fiu.edu/etd

Part of the Cultural History Commons, Diplomatic History Commons, $\underline{\text { History of Science, }}$ Technology, and Medicine Commons, Latin American History Commons, and the United States History Commons

\section{Recommended Citation}

Silvia, Adam M., "Haiti and the Heavens: Utopianism and Technocracy in the Cold War Era" (2016). FIU Electronic Theses and Dissertations. 2544.

https://digitalcommons.fiu.edu/etd/2544

This work is brought to you for free and open access by the University Graduate School at FIU Digital Commons. It has been accepted for inclusion in FIU Electronic Theses and Dissertations by an authorized administrator of FIU Digital Commons. For more information, please contact dcc@fiu.edu. 


\title{
FLORIDA INTERNATIONAL UNIVERSITY
}

\author{
Miami, Florida
}

\section{HAITI AND THE HEAVENS: \\ UTOPIANISM AND TECHNOCRACY IN THE COLD WAR ERA}

\author{
A dissertation to be submitted in partial fulfillment of the \\ requirements for the degree of \\ DOCTOR OF PHILOSOPHY \\ in \\ HISTORY \\ by
}

Adam M. Silvia

2016 
To: Dean John Stack

Green School of International and Public Affairs

This dissertation, written by Adam M. Silvia, and entitled Haiti and the Heavens:

Utopianism and Technocracy in the Cold War Era, having been approved in respect to style and intellectual content, is referred to you for judgment.

We have read this dissertation and recommend that it be approved.

Alexandra Cornelius

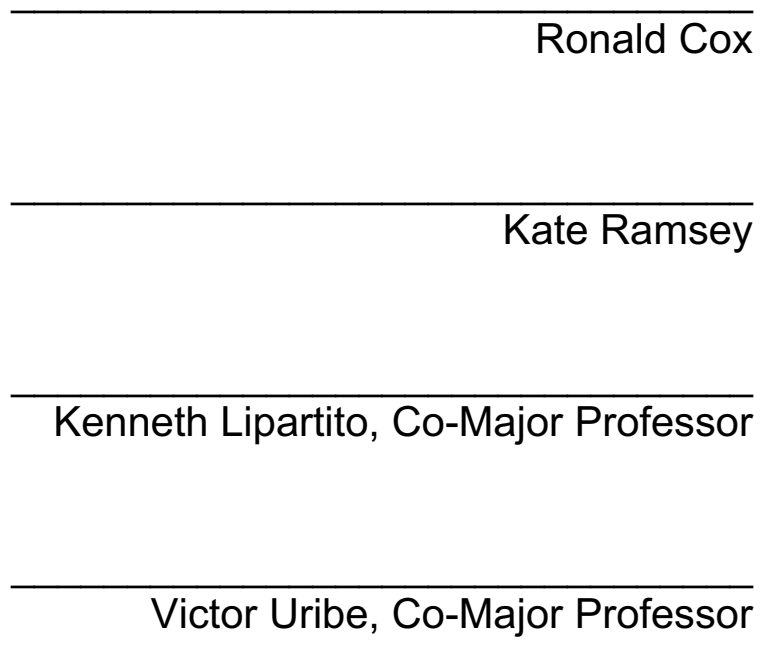

Date of Defense: June 2, 2016

The dissertation of Adam M. Silvia is approved.

Dean John Stack Green School of International and Public Affairs

Andrés G. Gil Vice President for Research and Economic Development and Dean of the University Graduate School

Florida International University, 2016 
(C) Copyright 2016 by Adam M. Silvia

All Rights Reserved

\begin{abstract}
Chapter 3, "Family Planning in Fond Parisien," was previously published as "Modern Mothers for Third World Nations: Population Control, Medical Imperialism, and Cold War Politics in Haiti," Social History of Medicine 27, no. 2 (May 2014): 260-280. Republished with permission by Oxford University Press and the Society for the Social History of Medicine.
\end{abstract}

Figures 2, 3, 9, 17, 21 @ by Bernard Diederich, 10, 11, 12, 13, 14 @ by Andover-Harvard Theological Library, 16 @ by Global Communities, 20 @ by Reason, 22 @ by Caribbean-Central America Action, 24 @ by Bill Bollendorf. Reproduced with permission. 


\section{DEDICATION}

I dedicate this dissertation to my parents. 


\section{ACKNOWLEDGMENTS}

Foremost, I would like to thank my committee. Dr. Kenneth Lipartito and Dr. Victor Uribe were kindly advisors. Dr. Ronald Cox, who previously served on my master's thesis committee, Dr. Kate Ramsey, and Dr. Alexandra Cornelius were also very supportive.

Additionally, I would like to acknowledge the History Department at Florida International University and everyone who provided commentary my research: Victor Bulmer-Thomas, Julio Capo, David Noble Cook, Paula de la CruzFernández, Erika Edwards, Jean-Claude Garcia-Zamor, Hadassah St. Hubert, Sherry Johnson, and Alex Lichtenstein.

I greatly appreciate the support of the University Graduate School, which awarded me both the Evidence Acquisition Fellowship and the Dissertation Writing Fellowship. I was also given the Foreign Language Area Studies Fellowship by the Latin American and Caribbean Center and the Green Family Fellowship for Latin American and Caribbean Studies by the Green Family Foundation.

I am proud to say that my dissertation utilizes the new Bernard Diederich Collection at the Steven and Dorothea Green Library. I would like to thank Bernard Diederich, who let me organize the collection, and Mireille Charles, Annia González, Kimberly Green, Dimmy Herard, Rose Nicholson, and Brooke Wooldridge, who supported the acquisition process.

I would also like to thank Marie Yvette and Faubert St. Hubert, who invited me with stay with them in New York; the Unitarian Universalist Congregation of 
Miami; Fran O'Donnell, who helped me access the Unitarian Universalist Service Committee Records in Cambridge; and Annie Mueller, who welcomed me to Global Communities in Silver Spring. 


\section{ABSTRACT OF THE DISSERTATION \\ HAITI AND THE HEAVENS: \\ UTOPIANISM AND TECHNOCRACY IN THE COLD WAR ERA}

by

Adam M. Silvia

Florida International University, 2016

Miami, Florida

\section{Professor Kenneth Lipartito, Co-Major Professor \\ Professor Victor Uribe, Co-Major Professor}

This study examined technocracy in Haiti in the Cold War era. It showed how Haitian and non-Haitian technicians navigated United States imperialism, Soviet ideology, and postcolonial nationalism to implement bold utopian visions in a country oppressed by poverty and dynastic authoritarianism. Throughout the mid-to-late twentieth century, technicians lavished Haiti with plans to improve the countryside, the city, the workplace, and the home. This study analyzed those plans and investigated the motivations behind them. Based on new evidence discovered in the private correspondence between Haitian, American, and Western European specialists, it questioned the assumption that technocracy was captivated by high-modernist ideology and US hegemony. It exposed how many technicians were inspired by a utopian desire to create a just society—one based not only on technical knowledge but also on humanist principles, such as liberty and equality. Guided by the utopian impulse, technicians occasionally disobeyed policymakers who wished to promote modernization and the capitalist 
world-economy. In many cases, however, they also upset the Haitian people, who believed technocracy was too exclusive. This study concluded that technicians were empowered by expertise but unable to build the utopias they envisioned because they were constantly at odds with both policymakers at the top and the people whose lives they planned. 


\section{TABLE OF CONTENTS}

CHAPTER

PAGE

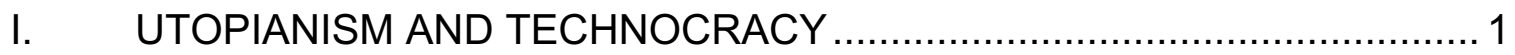

II. REGIONAL PLANNING IN THE ARTIBONITE VALLEY ........................40

III. FAMILY PLANNING IN FOND PARISIEN ............................................ 94

IV. URBAN PLANNING IN AND OUTSIDE PORT-AU-PRINCE.................139

V. CENTRAL PLANNING AND THE NEW RIGHT ................................ 183

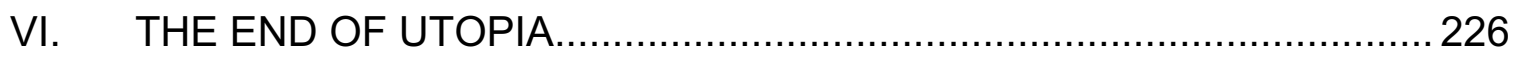

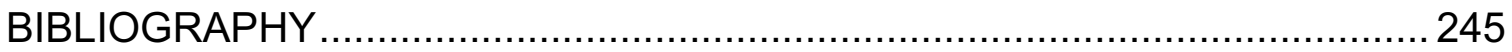

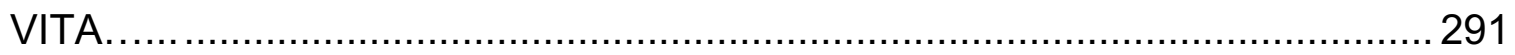




\section{LIST OF FIGURES}

FIGURE PAGE

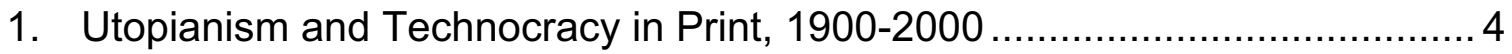

2. Harry Yoe, Director of the United States Operations Mission to Haiti.......... 12

3. Marc Holly, Co-Chairman of the Organisation de Développement

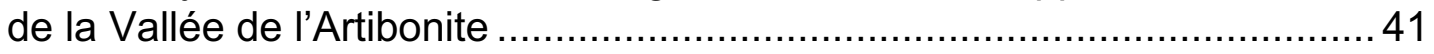

4. The Association of the Valley Plan with the Valley Section .........................49

5. The Institute of Inter-American Affairs in the Artibonite Valley.....................60

6. Norman Ward, USG Technician with Haitian Specialists Outside the

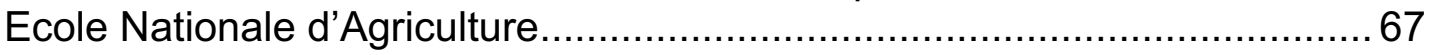

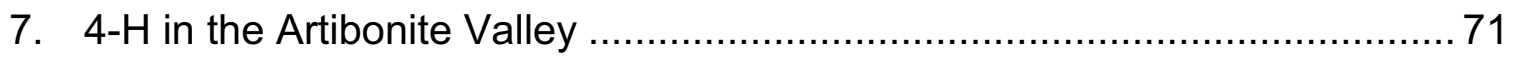

8. Norris, Tennessee and Deschapelle, Haiti................................................ 72

9. Centrale Hydro-Electrique François Duvalier de Péligre, Commemorative Medallion Minted in 1970

10. Alice Sheridan, Spokeswoman of the Unitarian Universalist Service Committee with François Duvalier ............................................... 106

11. The Centre d'Hygiène Familiale in Fond Parisien.................................. 110

12. CHF Wagoneer and Movie Projector ..................................................... 124

13. Children with Quand nous serons grands ........................................... 127

14. Ary Bordes, Haitian Physician .............................................................. 133

15. Blueprint for Washing Machines in Haiti .................................................. 150

16. Wallace Campbell, President of the Foundation for Cooperative Housing International, Inc. with Robert Dodge and Jack Edmondson........ 154

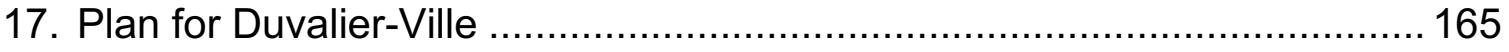

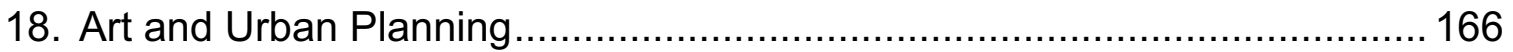

19. Plan for Model Homes in St. Martin ..................................................... 178 
20. Leslie Delatour, Ministre de Finance.

21. André Apaid, Haitian Businessman ……………................................. 194

22. Frederic Brooks, CEO of MacGregor Sporting Goods with Henri Namphy, David Miller of Eden Toys, Indira Jhappan of CaribbeanCentral America Action, and Joel Thebaux of PROMINEX ....................... 214

23. Ronald Reagan, President of the United States with Henri Namphy in the White House on 21 November 1986 215

24. "Bourik Chaje" by Franz Zephirin .... 239 


\section{ABBREVIATIONS AND ACRONYMS}

$\begin{array}{ll}\text { ADIH } & \text { Association des Industries d'Haïti } \\ \text { AFL-CIO } & \begin{array}{l}\text { American Federation of Labor and Congress of Industrial } \\ \text { Organizations }\end{array} \\ \text { CATH } & \text { Centrale Autonome des Travailleurs Haïtiens } \\ \text { CBI } & \text { Caribbean Basin Initiative } \\ \text { C-CAA } & \text { Caribbean-Central American Action } \\ \text { CHBP } & \text { Center for Housing, Building, and Planning } \\ \text { CHF } & \text { Centre d'Hygiène Familiale } \\ \text { CHISS } & \text { Centre Haïtien d'Investigation en Sciences Sociales } \\ \text { CNG } & \text { Conseil National de Gouvernement } \\ \text { CONADEP } & \text { Conseil National de Développement et de Planification } \\ \text { DLF } & \text { Development Loan Fund } \\ \text { ENAOL } & \text { Entreprise Nationale des Oléagineux } \\ \text { FCH } & \text { Foundation for Cooperative Housing } \\ \text { FCHI } & \text { FCH International, Inc. } \\ \text { FRAPH } & \text { Front pour l'Avancement et le Progrès Haïtien } \\ \text { GDP } & \text { Gross Domestic Product } \\ \text { HACOR } & \text { Haitian Agricultural Corporation } \\ \text { HAMCHAM } & \text { Haitian-American Chamber of Commerce } \\ \text { HASCO } & \text { Haytian-American Sugar Company } \\ \text { HHFA } & \text { Housing and Home Finance Agency } \\ \text { HUD } & \text { Department of Housing and Urban Development } \\ \text { ICA } & \text { International Cooperative Administration } \\ \text { IDB } & \text { Inter-American Development Bank } \\ & \\ \text { Hen } & \end{array}$




\begin{tabular}{ll} 
IIAA & Institute of Inter-American Affairs \\
IMF & International Monetary Fund \\
IPPF & International Planned Parenthood Federation \\
KONAKOM & Komité Nasyonal Kongrés Mouvman Demokratik \\
KTA & Knappet-Tippetts-Abbett Engineering Company \\
MIDH & Mouvement pour Instaurer la Démocratie en Haïti \\
MIT & Massachusetts Institute of Technology \\
MNR & Mouvement National de Rénovation \\
NGO & Non-Governmental Organization \\
OACO & Office d'Administration des Cités Ouvrières \\
ODC & Office du Développement Communautaire \\
ODVA & Organisation de Développement de la Vallée de l'Artibonite \\
OEO & Office of Economic Opportunity \\
ONL & Office National du Logement \\
PADCO & Planning and Development Collaborative International \\
PCH & Parti Communiste Haïtien \\
PROMINEX & Center for the Promotion of Investment and Exports \\
RPAA & Regional Planning Association of America \\
SCIPA & Service Coopératif Inter-Américain de Production Agricole \\
SFHD & Société Financière Haïtienne de Développement \\
SHADA & Société Haïtiano-Américaine Développement \\
TVA & Tennessee Valley Authority \\
UN & United Nations \\
UNDP & United Nations Development Programme \\
\hline
\end{tabular}




$\begin{array}{ll}\text { USAID } & \text { United States Agency for International Development } \\ \text { USG } & \text { United States Government } \\ \text { USOM } & \text { United States Operations Mission to Haiti } \\ \text { UUA } & \text { Unitarian Universalist Association } \\ \text { UUSC } & \text { Unitarian Universalist Service Committee } \\ \text { VSN } & \text { Milice Volontaires de la Sécurité Nationale }\end{array}$




\section{UTOPIANISM AND TECHNOCRACY}

In 1959, Harry Yoe, the Director of the United States Operations Mission to Haiti (USOM), wrote a speech to motivate his colleagues. "Who are we?" he began. "We [are] technicians... specialists in agriculture, education, public health, and public works. We [are] agronomists, engineers, teachers, teacher-trainers, nurses, [and] irrigation experts." USOM employed both US government (USG) technicians and Haitian specialists. It was "the local office of the International Cooperation Administration (ICA)," Yoe explained, "an agency of the United States government [and] an integral part of the Department of State." Yoe, an expert on marine biology, hoped to solve Haiti's oppressive poverty. "[We] are trying to give away ideas, knowledge, and technical skills, because these are the things that will enable [the Haitian] people to help themselves," he proclaimed. "If a man knows how to farm better, or to protect his health or to read, he's obviously in a better position to cope with his own problems than if he doesn't know these things."

Yoe advocated technocracy: a society designed and managed by educated elites. He believed that an expertly-crafted plan could put Haiti on the

1. Harry Yoe, Address (1959), United States Operations Mission to Haiti, Classified Subject Files, 1952-1962 (OMCF), box 1: "Director's Files, 1959," 3680009. Records of the Foreign Assistance Agencies, 1948-1961, Record Group 469, Entry No. 260, National Archives at College Park, Maryland (NACP). 
path to happiness-and he was not alone. In the mid-to-late twentieth century, technicians like Yoe lavished Haiti with plans to improve the countryside, the city, the workplace, and the home. My dissertation will survey those plans and investigate what truly motivated the technicians behind them. The "teknisyen," as they were called, included Haitian and Western European specialists, as well as USG personnel. Employed not only by USOM but also by the Haitian government and various private organizations, they were not particularly well organized. Empowered by technical expertise, however, they had an extraordinary impact on the people whose lives they planned. Technocracy is thus important to both the history of Haiti and the history of international diplomacy.

The term "technocracy" emerged in the early twentieth century, when highly-skilled managers were hired to supervise businesses throughout the US. ${ }^{2}$ William Henry Smyth, a self-styled "inventor of many machines and mechanical devices," popularized the term in the journal, Industrial Management, in 1919. ${ }^{3}$ Enamored with the War Industries Board established by the US government in 1917, Smyth envisioned "nationwide industry managed by technologists." While

2. As explained by Alfred Chandler, Jr. in The Visible Hand: The Managerial Revolution in American Business (Cambridge: Belknap Press, 1977), 315, "the visible hand of management [gradually] replaced the invisible hand of market forces" between 1840 and 1910, "coordinating the flow [of goods] from the suppliers of raw materials to the ultimate consumer."

3. W.H.G. Armytage, The Rise of the Technocrats: A Social History (New York: Routledge, 2006), 239.

4. William Henry Smyth, Technocracy (Berkeley: N.p., 1921), 34. 
the War Industries Board coordinated the munitions industry, Smyth wanted "technologists" to build a whole new society of "free and socially equal workers, scientifically organized for mutual benefit and unified purpose."

In 1919, likeminded Americans led by Thorstein Veblen, Howard Scott, and Stuart Chase organized a "Technical Alliance." Inspired by Edward Bellamy, whose novel, Looking Backward: 2000-1887 (1888), depicted a socialist utopia, the Alliance insisted that specially-trained experts govern the nation. ${ }^{6}$ As explained by Chase, the Alliance embraced technocracy as both "a prophecy and a challenge [that] hinted at a blueprint of a possible new society where economic activity is controlled by the technician." Although the Alliance dissolved in 1921, Scott organized a new "Committee on Technocracy" at Columbia University in 1932, and the Alliance's philosophy was partially incorporated into the New Deal

5. William E. Akin analyzes the Technical Alliance in Technocracy and the American Dream: The Technocrat Movement, 1900-1941 (Berkeley: University of California Press, 1977), 1-45. Also see Machine-Age Ideology: Social Engineering and American Liberalism, 1891-1939 (Chapel Hill: University of North Carolina Press, 1994) by John M. Jordon, who emphasizes the Alliance's "bedrock commitment to the power of reason."

6. Edward Bellamy, Looking Backward: 2000-1887 (New York: Oxford University Press, 2009, originally published in 1888), 166. "No sooner had the nation become the sole capitalist and employer," Bellamy wrote, "than "humanity's ancient dream of liberty, equality, fraternity, mocked by so many ages, at last was realized."

7. Stuart Chase, Technocracy: An Interpretation (New York: John Day, 1933), 11. 


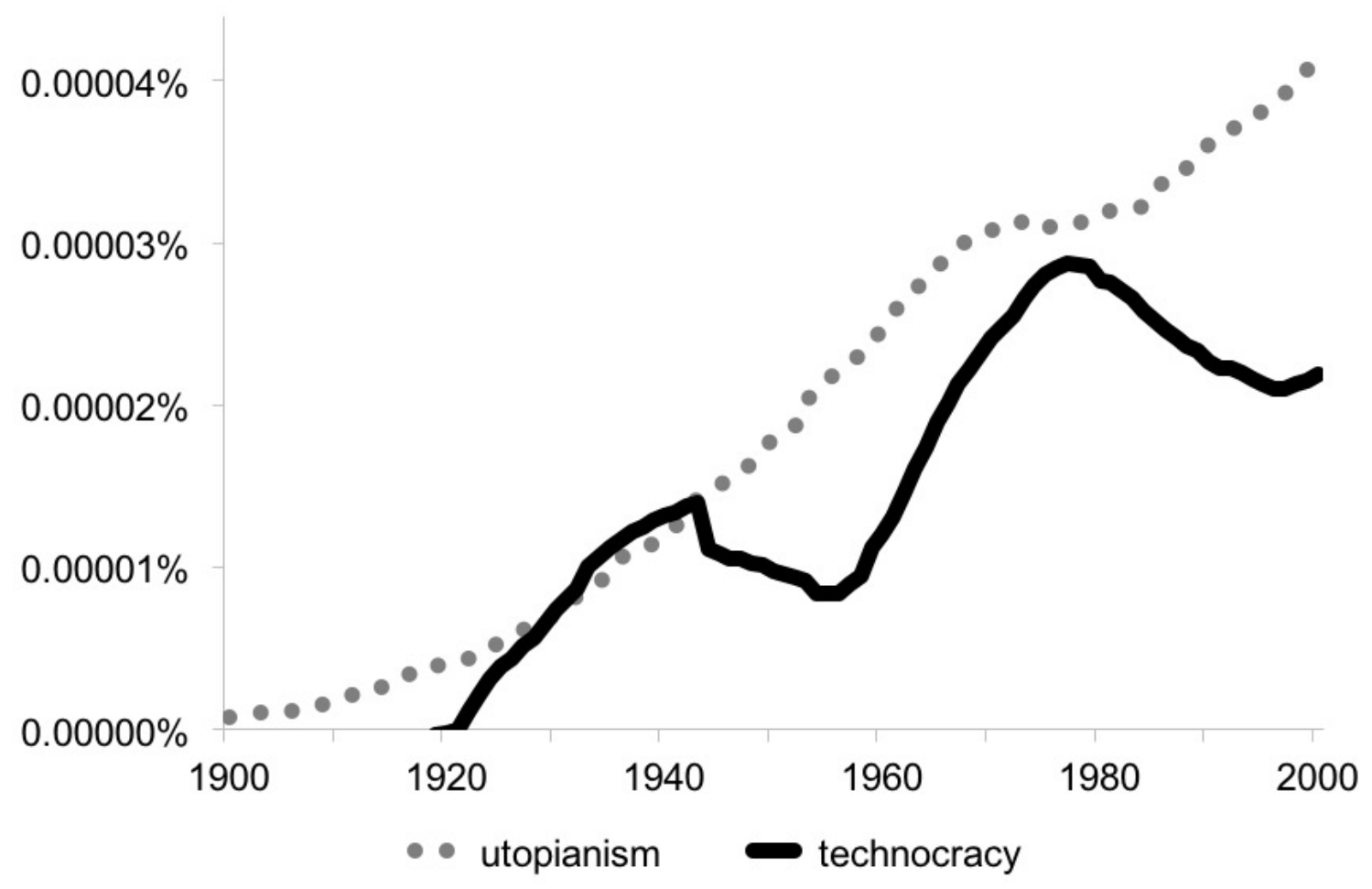

Fig. 1 Utopianism and Technocracy in Print, 1900-2000. Generated by the Google Books Ngram Viewer, http://books.google.com/ngrams, this graph displays how often the words "utopianism" and "technocracy" appeared in books published in English relative to other terms.

by President Franklin Roosevelt, who assembled a well educated "Brains Trust" to address the Great Depression. ${ }^{8}$

Technocracy declined in popularity by the mid twentieth century (Fig. 1).

Witness to World War II, which claimed between 60 and 80 million lives, many people came to see modern technology as potentially dangerous. In the book, Dialectic of Enlightenment (1944), Max Horkheimer and Theodor W. Adorno

8. As economist Rexford G. Tugwell attests in The Brains Trust (New York: Viking, 1968), Roosevelt's advisors included not only him but also Adolf Berle, Raymond Moley, Basil O'Connor, and Samuel Rosenman. 
noted how technical knowledge became an instrument to tyrannize the European continent. "Enlightenment, understood in the widest sense as the advance of thought, has always aimed at liberating human beings from fear and installing them as masters," they bewailed, "yet the wholly enlightened earth is radiant with triumphant calamity!" ${ }^{9}$ Friederich Hayek echoed these sentiments in The Road to Serfdom (1944), which blamed Nazism on the technocrats' vain attempt to manipulate the economy as they would a machine. ${ }^{10}$

When Harry Yoe arrived in Haiti in 1959, however, technocracy was making a comeback. Weakened by WWII, the European powers were unable to suppress colonial independence movements, which yielded new nations and new political bureaucracies throughout Africa, Asia, the Middle East, and the West Indies. Meanwhile, the Union of Soviet Socialist Republics (USSR) had implemented central planning and diverted its money to state-owned industries. ${ }^{11}$ The Soviet Union's metamorphosis into a mighty superpower captivated the world's imagination, threatening US hegemony. In response, the US sponsored

9. Max Horkheimer and Theodore W. Adorno, Dialectic of Enlightenment, trans. Edmund Jephcott (Stanford: Stanford University Press, 2002, originally published in 1944), 1-2.

10. Friedrich A. Hayek, The Road to Serfdom (Chicago: University of Chicago Press, 2007, originally published in 1944), 41-42.

11. Don K. Rowney analyzes Soviet technocracy in his book, Transition to Technocracy: The Structural Origins of the Soviet Administrative State (Ithaca: Cornell University Press, 1989). 
governments that opposed the USSR and employed its own technicians to compete with Soviet ideology around the world. ${ }^{12}$

Technicians like Harry Yoe were thus pulled into a "Global Cold War" that evolved at the intersection between postcolonial nationalism, US imperialism, and Soviet expansionism. ${ }^{13}$ "We're on the spot!" Yoe exclaimed. Nations like Haiti "want to develop," but only "we [the technicians] have the key." ${ }^{14}$ Yoe warned that Haiti would ally with the USSR unless USOM solved the country's problems. Haiti "won't go without help" he stated. "The communists are aware of these things." Surely, they would "try to do something about it!"

The political leadership in Washington wanted technicians to "develop" countries like Haiti. As a blueprint, President John F. Kennedy embraced The Stages of Economic Growth: A Non-Communist Manifesto (1960) by Walt W. Rostow, a professor at the Massachusetts Institute of Technology. Rostow promoted "modernization theory:" the idea that nations "mature" into wealthy

12. As explained by David C. Engerman in Modernization from the Other Shore: American Intellectuals and the Romance of Russian Development (Cambridge: Harvard University Press, 2004), the Soviet Union's success inspired many intellectuals in the US to advocate technocracy in the Global South.

13. Odd Arne Westad outlines this struggle in The Global Cold War: Third World Interventions and the Making of Our Times (New York: Cambridge University Press, 2005). Also see Robert J. McMahon, The Cold War in the Third World (New York: Oxford University Press, 2013); Michael E. Latham, "The Cold War in the Third World, 1963-1975," in The Cambridge History of the Cold War, eds. Melvyn P. Leffler and Odd Arne Westad, vol. 2 (New York: Cambridge University Press, 2010), 258-80.

14. Yoe, Address (1959). 
democracies like the US. ${ }^{15} \mathrm{~A}$ "traditional society, based on pre-Newtonian science and technology," he argued, would "take off" once the "insights of modern science began to be translated into new production functions in both agriculture and industry." ${ }^{16}$ In theory, the US could accelerate "development" by supplying technology.

Rostow believed that all of humanity shares a common destiny—a golden age of "high mass-consumption." Modernization, he declared, would "open up [the] expansion of consumption levels beyond basic food, shelter, and clothing." ${ }^{17}$ Like in the mythical Land of Cockayne, everyone would have access to an irresistible emporium of modern goods and services. ${ }^{18}$ As explained by Susan Buck-Morss, modernization theory presented its constituency with a "dreamworld," in which "the industrial reshaping of the world [was] capable of

15. In his book, Mandarins of the Future: Modernization Theory in Cold War America (Baltimore: Johns Hopkins University Press, 2003), 13, Nils Gilman explains how modernization theory articulated a "high-concept version of Americanism: materialism without class conflict, secularism without irreverence, democracy without disobedience."

16. Walt W. Rostow, The Stages of Economic Growth: A Non-Communist Manifesto (New York: Cambridge University Press, 1968, originally published in 1960), 4-6.

17. Ibid., 73.

18. Victoria De Grazia's book, Irresistible Empire: America's Advance Through Twentieth-Century Europe (Cambridge: Belknap Press, 2005), 4, exposes how "the United States turned its power as the premier consumer society into [a] dominion that came from being universally recognized as the fountainhead of modern consumer practices." Also see A Consumer's Republic: The Politics of Mass Consumption in Postwar America (New York: Vintage, 2008) by Lizabeth Cohen, who analyzes the culture of "high mass-consumption." 
bringing about the good society by providing material happiness for the masses." 19

Many scholars think that modernization theory captivated the technician. In his book, Modernization as Ideology (2000), Michael Latham describes it as the "perceptual framework through which much broader, widespread understandings of America's national identity, mission, and world role were apprehended. ${ }^{20}$ Hardwired into the technician's psyche, says Latham, was the link between technology and prosperity touted by Rostow. Modernization as Ideology echoes the widely-read Seeing Like a State (1998) by James C. Scott. ${ }^{21}$ According to Scott, technicians were "uncritical, unskeptical" zealots. As the

19. Susan Buck-Morss, Dreamworld and Catastrophe: The Passing of Mass Utopia in East and West (Cambridge: MIT Press, 2000), ix.

20. Michael E. Latham, Modernization as Ideology: American Social Science and "Nation-Building" in the Kennedy Era (Chapel Hill: University of North Carolina Press, 2000), 13. Also see Dominance by Design: Technological Imperatives and America's Civilizing Mission (Cambridge: Belknap Press, 2006) by Michael Adas, who examines how "technological proficiency and material accomplishments" in the US "shape[d] prejudices that affected everyday social interaction and informed American ideologies of dominance."

21. Latham's work also builds upon Ideology and US Foreign Policy (New Haven: Yale University Press, 1987) by Michael Hunt, Liberal America and the Third World: Political Development Ideas in Foreign Aid and Social Science (Princeton: Princeton University Press, 1973) by Robert A. Packenham, and Spreading the American Dream: American Economic and Cultural Expansion, 1890-1945 (New York: Hill \& Wang, 1982) by Emily S. Rosenberg. Also see Encountering Development: The Making and Unmaking of the Third World (Princeton: Princeton University Press, 1995) by Arturo Escobar, who approaches modernization as a "discourse." Escobar cites Michel Foucault, whose book, Power/Knowledge (New York: Pantheon, 1980), explains how "the exercise of power... creates and causes to emerge new objects of knowledge" and, "controversly, [this] knowledge," known as discourse, "constantly induces effects of power." 
"carriers of high-modernist ideology," they promoted "scientific and technical progress, the expansion of production, the growing satisfaction of human needs, the mastery of nature, including human nature," and "the rational design of social order commensurate with the scientific understanding of natural laws."22

Scott associates technocracy with tyranny. Technicians thought in "remarkably aesthetic terms" that made "geometrical sense," he claims, but they "excluded the necessary role of local knowledge."23 Much like the Ancient Greeks, Scott distinguishes between technical knowledge that is applicable anywhere, what Plato and Aristotle described as "techne," and the unique wisdom that evolves in a given locality, "mētis." ${ }^{24}$ Technocracy, which derived from the Greek word, "techne," is potentially "imperialist," Scott argues, because it seeks to impose a universal vision on society. "The destruction of mētis and its replacement by standardized formulas legible only from the center is virtually inscribed in the activities of both the state and large-scale bureaucratic capitalism," even though mētis "is the mode of reasoning most appropriate to complex material and social tasks." ${ }^{25}$ Like novelist Forest Horton, Jr., Scott

22. James C. Scott, Seeing Like a State: How Certain Schemes to Improve the Human Condition Have Failed (New Haven: Yale University Press, 1998), 4.

23. Ibid., 4-6.

24. Marcel Detienne and Jean-Pierre Vernaut analyze "techne" and "mētis" in Cunning Intelligence in Greek Culture and Society, trans. Janet Lloyd (Atlantic Highlands: Humanities Press, 1978, originally published in 1974). Also see Jacques Brunschwig and Geoffrey E.R. Lloyd, Greek Thought: A Guide to Classical Knowledge (Cambridge: Belknap Press, 2000).

25. Scott, Seeing Like a State, 363, 370. 
emphasizes how plans based on technical knowledge have occasionally yielded dystopias. ${ }^{26}$

William Easterly makes the same point in The Tyranny of Experts (2013), which delineates a symbiotic relationship between technicians and authoritarian governments. "Experts may actually welcome an autocrat," Easterly asserts, especially when autocracy suppresses opposition to technocracy. "An autocrat," meanwhile, "can use the expert promotion of development as part of his rationale for autocratic rule." ${ }^{27}$ Easterly points to Chiang Kai-shek in China, Kwame Nkrumah in Ghana, and Laureano Gómez in Colombia as examples. Technicians who worked beside despots like Gómez had a "terrible naïveté about power," says Easterly. Misled by the "technocratic illusion [that] poverty results from a shortage of expertise," they excused tyranny and were complicit in "covering up the rights of the poor." 28

Easterly's opinion is very common, especially in the historiography on Latin America. In his book, Modernization and Bureaucratic-Authoritarianism (1973), Guillermo O'Donnell underlines how import-substitution industrialization in nations like Argentina and Brazil was centrally managed by despotic

26. In The Technocrats (1980) by Forest Horton, Jr., the US government obsesses with technology. It uses an advanced "electronic device" to make decisions, unaware that the Soviet Union had secretly programmed the tool to make illogical computations.

27. William Easterly, The Tyranny of Experts: Economists, Dictators, and the Forgotten Rights of the Poor (New York: Basic Books, 2013), 31.

28. Ibid., 6-7. 
governments with large bureaucracies. "The term "bureaucratic," he states, "suggests the crucial features that are specific to authoritarian systems of high modernization: the growth of organizational strength of many social sectors, the governmental attempts at control, the career patterns and power-bases of most incumbents of technocratic roles, and the pivotal role played by large bureaucracies.. ${ }^{29}$ Empowered by technical knowledge, the técnicos imposed various plans on Latin American populations without any consultation. "Coercion was widespread," explains O'Donnell. It provoked "popular unrest, terrorism, and manifold indications of growing general disaffections." 30

While scholars like Scott and Easterly portray technicians as maniacal modernizers who colluded with dictators to promote an unsuitable ideology, the people who advocated technocracy in Haiti seem hardly diabolical. "[We are] people, just good ordinary people," Harry Yoe attested. "[We] live in this community" and "go to church on Sundays" (Fig. 2). ${ }^{31}$ Yoe was Episcopalian. He

29. Guillermo A. O'Donnell, Modernization and Bureaucratic-Authoritarianism: Studies in South American Politics (Berkeley: University of California, Institute of International Studies, 1973), 95. Also see Albert O. Hirschman, "Explaining the Emergence of Bureaucratic-Authoritarianism" and Robert R. Kaufman, "Industrial Change and Authoritarian Rule in Latin America," in The New Authoritarianism in Latin America, ed. David Collier (Princeton: Princeton University Press, 1979); Silvio Duncan Baretta and Helen E. Douglass, "Authoritarianism and Corporatism in Latin America: A Review Essay," in Authoritarianism and Corporatism in Latin America, ed. James Malloy (Pittsburgh: University of Pittsburgh Press, 1976), 513-26. Eduardo Dargent provides a contrastingly nuanced analysis in Technocracy and Democracy in Latin America: The Experts Running Government (New York: Cambridge University Press, 2015).

30. O'Donnell, 97.

31. Yoe, Address (1959). 


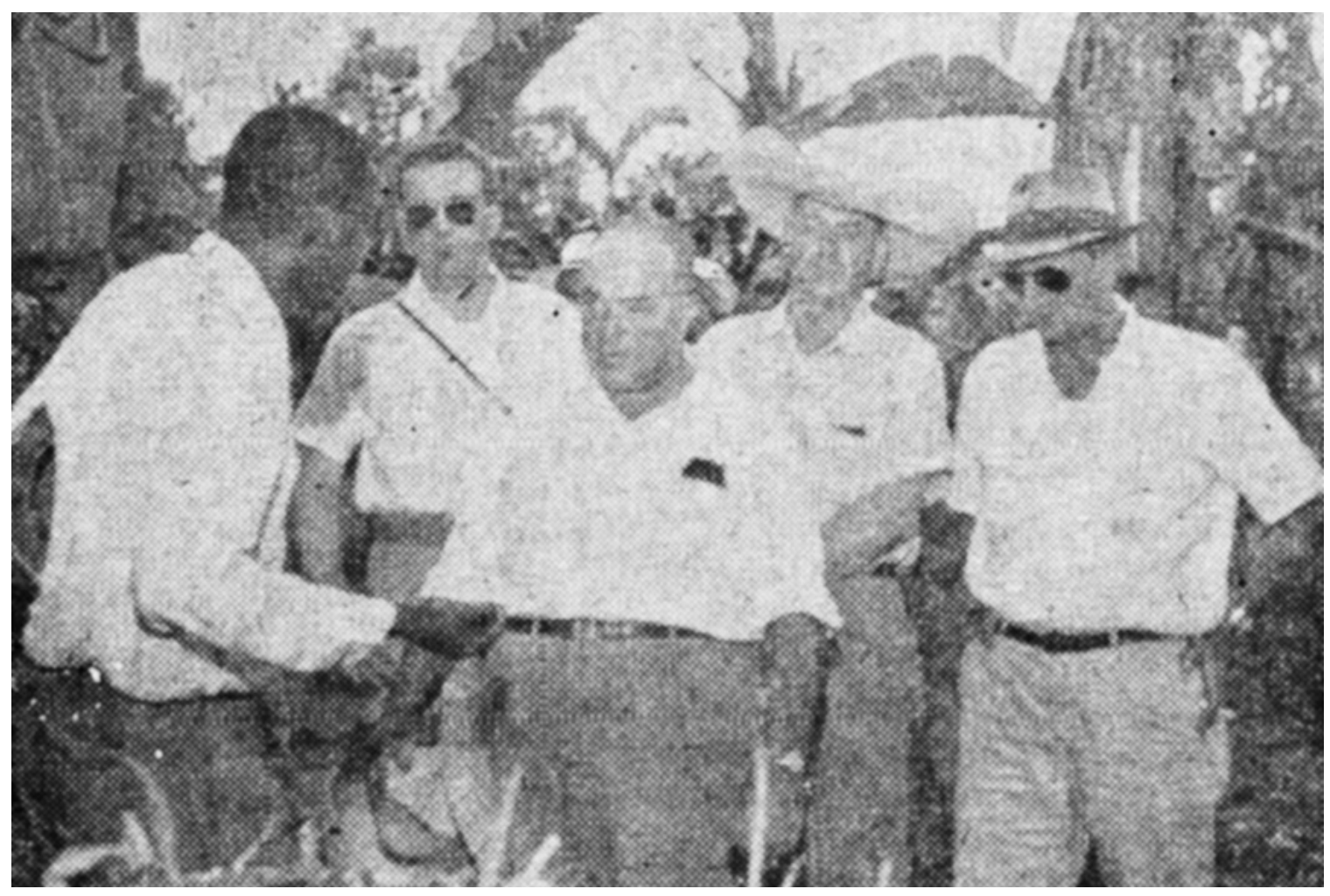

Fig. 2 Harry Yoe (far right), Director of the United States Operations Mission to Haiti. Photo by Bernard Diederich. From: Haiti Sun (8 November 1959): 1. Reproduced with permission.

was born in West Virginia and went to West Virginia University. He previously served in the Navy and was a consultant to General Douglas MacArthur in occupied Japan. Like Walt W. Rostow, he believed technology was important, but he was not a zealot. "[Many] have got it in their heads that the resources of a modern industrialized society are such that it is possible to at last solve the ageold anxieties of man," he noted. "Maybe they are right," but then again, "maybe they are wrong." ${ }^{32}$ He debated how to proceed in Haiti. "I am not all that sure that

32. Ibid. 
I nor any of [us] technicians really know how to modernize a people," he admitted. "We are trying, by experiment, to find [a] way. Personally, I am confident that we shall succeed!"

Given the obvious disparity between how technicians perceived themselves and how they are portrayed in the historiography, my dissertation will analyze what they hoped to accomplish and assess the plans they implemented. I would like to know-what inspired technocracy? Was it captivated by modernization theory? Did technicians like Yoe obey policymakers who discounted local knowledge? Did they embrace autocracy as stated by Easterly? Were they themselves tyrants as insinuated by Scott? Finally, how should we conceptualize technocracy in the Cold War era?

\section{A Utopian Intervention}

I will address these questions by analyzing technocracy in Haiti, a Caribbean nation that has experienced many hardships throughout history. Haiti occupies western Hispaniola, an island that was conquered in 1503 by the Spanish. In 1697, Spain abandoned the territory to France, which named it SaintDomingue. As chronicled by Laurent Dubois, the French imported and enslaved Africans to work on large plantations-that was until 1791, when a slave revolt sparked the Haitian Revolution, a 13-year struggle that culminated in national 
independence. ${ }^{33}$ Once independent, however, Haiti was immediately ostracized by slave-owning countries, including the US. ${ }^{34}$ The plantation economy largely dissolved into a peasantry, and the state had to use what little money it possessed to pay reparations to the French.

Meanwhile, Haiti had to cope with its colonial legacy, which begot inequality between the black population and a milat (mixed-blood) minority that was disproportionately wealthy and politically assertive. ${ }^{35}$ In the mid twentieth century, a black, middle-class physician named François Duvalier promised to promote the black population vis-à-vis the milat minority. When he became president in 1957, however, he plundered the economy. As documented by journalists Bernard Diederich and Al Burt, he also instituted a militia, the Milice Volontaires de la Sécurité Nationale (VSN), also known as the Tonton Macoutes,

33. Laurent Dubois, Avengers of the New World: The Story of the Haitian Revolution (Cambridge: Belknap Press, 2004).

34. As shown by Elizabeth Maddock Dillon and Michael J. Drexler in The Haitian Revolution and the Early United States (Philadelphia: University of Pennsylvania Press, 2016), 8-9, "southern Republicans were ultimately willing to forego the profits of a thriving trade between the United States and [the Haitian people] out of fear that an antislavery revolt might spread from Haiti to the southern United States." Also see Matthew J. Clavin, Toussaint Louverture and the American Civil War: The Promise and Peril of a Second Haitian Revolution (Philadelphia: University of Pennsylvania Press, 2012); James Alexander Dun, Dangerous Neighbors: Making the Haitian Revolution in Early America (Philadelphia: University of Pennsylvania Press, 2016).

35. In his book, Red and Black in Haiti: Radicalism, Conflict, and Political Change, 1934-1957 (Chapel Hill: University of North Carolina Press, 2009), 198, Matthew J. Smith explains, "there is a strong correlation between color, class, and culture in Haiti." The term, "mulatto," in Haiti, "acknowledges phenotype but does not necessarily refer to social status." Like Smith, I instead use the word, "milat," which "contains reference to class and not just color." 
which he used to suppress his political opponents. ${ }^{36}$ In 1971 , he was succeeded by his son, Jean-Claude, who governed by decree until $1986 .^{37}$

It was in this context that a small army of technicians operated. Led by Harry Yoe, USOM intervened throughout the country. "We have to tackle a lot," Yoe explained, namely "agricultural improvement, public health improvement, educational improvement," and "the construction and repair of irrigation systems and country roads." ${ }^{38}$ As Yoe noted, however, "[USOM] doesn't pretend to do all of the job or even the greatest part of it." The Haitian government had its own Conseil National de Développement et de Planification (CONADEP), which employed local technicians. Meanwhile, Haitian physicians and US missionaries opened independent clinics in the countryside; Haitian economists consorted with multinational corporations; and Haitian architects worked with the United Nations (UN) and private contractors to renovate the Haitian capital, Port-au-Prince.

As one would expect, technocracy in Haiti was based primarily on technical knowledge. Nevertheless, it was surprisingly complex. Contrary to Scott's argument in Seeing Like a State, many technicians wished to supplement techne with mētis. They commonly advocated decentralization and sometimes

36. Bernard Diederich and Al Burt, Papa Doc: The Truth About Haiti Today (New York: McGraw-Hill, 1969). Also see Diederich's new books, The Price of Blood and The Murderers Among Us (Princeton: Markus Wiener Publishers, 2011).

37. Elizabeth Abbott examines Jean-Claude Duvalier's presidency in Haiti: The Duvaliers and Their Legacy (New York: McGraw-Hill, 1988).

38. Yoe, Address (1959). 
experimented with communitarianism and conservationism. While some planners looked down upon the peasantry, many genuinely praised it. "The Haitian peasant is a good fellow," Harry Yoe attested. "He works hard and [is] intelligent." ${ }^{39}$ Technicians like Yoe believed technocracy should capitalize on the peasant's cooperative practices, especially the "kombit," a tradition in which the community unites to accomplish a common task. Hence, they promoted credit unions, community centers, and youth clubs.

Technicians, I argue, were utopian. They imagined Haiti as a heavenly paradise built upon "more perfect principles.." ${ }^{40}$ The utopia they envisioned, however, had little in common with the "high mass-consumption" dreamworld promoted by Walt W. Rostow. No doubt, technicians wished prosperity upon the Haitian people, but they also desired a just society—a nation based not only on technical knowledge but also on humanist principles, such as liberty and equality. As elites, they sometimes interpreted those principles in conservative ways, but they were not devious tyrants. USG technicians like Harry Yoe believed it was "clumsy" and "objectionable" to implement plans without Haitian input. "Haiti is

39. Ibid.

40. In the oft-cited book, Defined by a Hollow: Essays on Utopia, Science Fiction and Political Epistemology (New York: Peter Lang, 2010), 30, Darko Suvin describes utopia as a "verbally constructed... community where sociopolitical institutions, norms and individual relationships are organized according to a more perfect principle than in the author's community, this construction being based on estrangement arising out of an alternative historical hypothesis." 


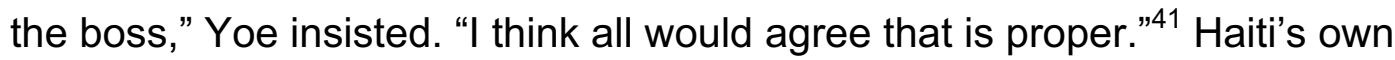
technicians, meanwhile, were devout nationalists. They hoped to empower the Haitian people and protect Haiti's national sovereignty.

As explained by Ruth Levitas in The Concept of Utopia (1990), "utopia is the expression of desire for a better way of being." It "involves the imagining of a state of being in which the problems which actually confront us are removed or resolved." ${ }^{\prime 2}$ Historically, many utopias were literary creations. Early modern novellas, such as Utopia (1516) by Thomas More, New Atlantis (1627) by Francis Bacon, and The Isle of Pines (1668) by Henry Neville, introduced imaginary new worlds. ${ }^{43}$ Utopian texts were also common in Latin America, evidenced by the Memorias o el dilatado cautiverio (1825) by Juan Batista Túpac Amaru and La raza cósmica (1925) by José Vasconcelos. ${ }^{44}$ In Greek, the word "utopia" means "nowhere" (оu тómos) ${ }^{45}$ The prospect that someone can apply what they know to

41. Yoe, Address (1959).

42. Ruth Levitas, The Concept of Utopia (New York: Peter Lang, 2010, originally published in 1990), 9, 221.

43. Susan Bruce, ed. Three Early Modern Utopias: Utopia, New Atlantis, and the Island of Pines (New York: Oxford University Press, 2009).

44. Kim Beauchesne and Alessandra Santos, The Utopian Impulse in Latin America (New York: Palgrave Macmillan, 2011), 8-9. Also see Beatriz Pastor Bodmer, El jardín y el peregrino: el pensamiento utópico en América Latina, 1492-1695 (Ciudad Universitaria: Universidad Nacional Autónoma de México, 1999).

45. Lucian Hölscher, “Utopie," Utopian Studies 7, no. 2 (1996): 1-2. 
invent a just society, however, has inspired experimental communities like New Harmony, Indiana and Oneida, New York. ${ }^{46}$

In much the same way, technicians in Haiti were motivated by what Ernst Bloch describes as the "utopian impulse." In his multivolume work, The Principle of Hope (1959), Bloch observes how humanity is "always searching to fill a hollow" and "eagerly looks forward to an imagined idea in which [its] desire [is] pictured." This "drive," he explains, sparks "imaginative ideas" that "extend, in an anticipating way, existing material into the future," exploring the "possibilities of being different and better." ${ }^{47}$ The utopian impulse, I argue, was ubiquitous in Haiti, where poverty and oppression galvanized those who desired a just society. Technicians visualized how Haiti should look then incorporated that vision into physical blueprints which they implemented to improve the country in every way imaginable.

Guided by the utopian impulse, technicians commonly transcended highmodernist ideology. In some instances, they even disobeyed policymakers who insisted they promote science and technology. As explained by Karl Mannheim in

46. Mark Holloway examines New Harmony and Oneida in Heavens on Earth: Utopian Communities in America, 1690-1880 (New York: Dover Publications, 1966), 101-97.

47. Ernst Bloch, The Principle of Hope (originally published in 1959), trans. Neville Plaice, Stephen Plaice, and Paul Knight, vol. 1 (Cambridge: MIT Press, 1986), 46, 144. Also see Ernst Bloch: utopie et espérance (Paris: Editions du Cerf, 1974) by Laënnec Hurbon, who discusses Bloch's opposition to structuralism in psychoanalysis, especially The Interpretation of Dreams (1900) by Sigmund Freud. 
Ideology and Utopia (1936), utopian thinking typically "shatters, either partially or wholly, the order of things prevailing at the time.." ${ }^{48}$ Contrary to Michael Latham's claim in Modernization as Ideology, technicians were not captivated by modernization theory. "The belief that the significance of individual creative power is to be denied is one of the most widespread misunderstandings of the findings of sociology," Mannheim bewails. "From what should [the] new be expected to originate if not from the novel and uniquely personal mind of the individual who breaks beyond the bounds of the existing order?"49

As Mannheim warns, however, "existing orders" rarely welcome new ideas. Such was the case in Haiti, where the Duvaliers pressured technicians to support the government's agenda. Educated in public health by the University of Michigan, François Duvalier generally embraced technical knowledge. When he became president, he promoted science and technology as means to legitimize dynastic authoritarianism. Technicians who proposed alternatives to "modernization" were thus a threat to his authority. The Duvaliers wished to control the country's imagination, explains Laënnec Hurbon. They discredited independent thinkers as "imperialists" and "communists" and threatened them with violence. ${ }^{50}$

48. Karl Mannheim, Ideology and Utopia (originally published in 1936), in Collected Works, eds. Louis Wirth and Bryan S. Turner, vol. 1 (New York: Routledge, 2003), 173.

49. Ibid., 186.

50. Laënnec Hurbon, Culture et dictature en Haïti: l'imaginaire sous contrôle (Port-au-Prince: Henri Deschamps, 1987), 86. 
Inconsistent with William Easterly's assumption that "experts may actually welcome autocrats," many technicians, in actuality, loathed the Duvaliers. They especially disliked the Duvaliers' cronyism. As noted by Harry Yoe, "[government employees who] consider themselves [to be] strong Duvalier supporters did not feel that it was necessary to work hard." In many cases, they "openly refused to make any real [effort]." ${ }^{51}$ Haiti's best technicians, meanwhile, "did not believe the government would support [them]." Yoe questioned the Duvaliers' sincerity and lamented how some planners chose not to think creatively because they were "afraid of political reprisals." Unsurprisingly, many technicians supported the military coup that ousted Jean-Claude Duvalier in 1986.

The Duvaliers, however, were not the only ones annoyed by the technicians' utopian impulse. Both policymakers and private contractors in the US had a vested interest in modernization theory and beseeched technicians to promote modern technology and the capitalist world-economy ${ }^{52}$ In his book, Utopistics (1998), Immanuel Wallerstein explains how "most revolutionaries intend to be revolutionaries" but eventually learn "they are constrained by the structures of the world-system" and those who support it. They must "behave in

51. Memo by Harry Yoe (10 October 1959), OMCF, box 2: "Application Approval, 1959," 3680026.

52. Mark Solovey exposes the economic interests behind modernization theory in Shaky Foundations: The Politics-Patronage-Social Science Nexus in Cold War America (New Brunswick: Rutgers University Press, 2013). Also see Radical History Review 21, no. 63 (Fall 1995), a special issue on "The Cold War and Expert Knowledge," coedited by Michael A. Bernstein and Allen Hunter. 
certain ways and within certain parameters or else they lose all capacity to be important actors. ${ }^{\text {} 53}$ This was certainly true in Haiti. Nevertheless, many Haitian technicians opposed private contractors who violated Haitian sovereignty and burdened the country with unnecessary debt.

My dissertation analyzes how technicians navigated political, economic, and cultural structures to implement bold utopian plans. It highlights the ways in which they transcended high-modernist ideology, US imperialism, and Duvalierism to promote a just society, but it also acknowledges the countless obstacles they encountered along the way. By combining structural and poststructural analysis, my study answers the plea by historian Gilbert M. Joseph to "supplement historical attention to the blending of social theory and power with poststructuralism's abiding concern with questions of contingency, representation, and difference. ${ }^{54}$

While I emphasize the tension between planners and policymakers, we should not overlook that between technocracy and the Haitian people. Technicians should possess "the kind of personal sensitiveness that enables them to work with people whose whole background, tradition, and outlook are much different from [their] own," explained Harry Yoe, but this was not always the

53. Immanuel Wallerstein, Utopistics: Historical Choices of the Twenty-First Century (New York: The Free Press, 1998), 12.

54. Gilbert M. Joseph, "Close Encounters: Toward a New Cultural History of US-Latin America Relations," in Close Encounters of Empire: Writing the Cultural History of US-Latin America Relations, eds. Joseph, Catherine C. Legrand, and Ricardo D. Salvatore (Durham: Duke University Press, 1998), 14-15. 
case ${ }^{55} \mathrm{~A}$ disreputable minority perpetuated stereotypes about non-white populations and belittled the Haitian religion, Vodou. Most technicians, I argue, were sincerely interested in the Haitian people. Much to the people's dismay, however, they lacked a bottom-up perspective. As a result, they commonly misinterpreted mêtis and sometimes implemented plans that worsened the problems they wished to solve. ${ }^{56}$ Technicians were empowered by expertise but unable to build the utopias they envisioned because they were constantly at odds with both policymakers at the top and the people whose lives they planned.

\section{Technocracy in Haiti}

My dissertation calls into question the notion that technicians are, by nature, unprincipled tyrants. This assumption is common in the historiography on Haiti and understandably so. While the word "technocracy" may not have evolved until the early twentieth century, the philosophy behind it was alive and well in colonial times, when technical knowledge was wrongly used to oppress the Haitian people. As explained by Trevor Burnard and John D. Garrigus in The

55. Yoe, Address (1959).

56. As noted by Frederic Engels in Socialism: Utopian and Scientific (originally published in 1883), in The Collected Works of Karl Marx and Frederic Engels, vol. 24 (London: Lawrence and Wishart, 1997), 31, utopias are typically subjective. "Each [person's] special kind of absolute truth, reason, and justice [is] conditioned by his subjective understanding, his conditions of existence, the measure of his knowledge and his intellectual training." 
Plantation Machine (2016), plantation slavery in Saint-Domingue was essentially a technocracy. "Managers grouped field workers according to their physical stamina," which "allowed them to enforce the rigid cultivation schedules that mills and boiling houses required." Those who possessed a "mastery of the details of raw materials, manufacturing constraints, and labor management produced more salable sugar. ${ }^{257}$

The utopian impulse originally evolved in opposition to plantation slavery, as both the enslaved population and the gens de couleurs (free people of color) envisioned a just society. In the eighteenth century, Saint-Domingue was home to nearly 30,000 gens de couleurs, many milat. Having obtained liberty through manumission, they demanded equality and persuaded the French National Assembly to extend the "Rights of Citizenship" to freeborn blacks. ${ }^{58}$ Meanwhile, many Africans tried to escape bondage on the plantation. Those who succeeded quickly vanished into the mountains, where they built independent communities. ${ }^{59}$ Finally, the enslaved population took up arms in 1791 . Joined by the gens de couleurs and the maroons, they overthrew the colonizers, created an

57. Trevor Burnard and John D. Garrigus, The Plantation Machine: Atlantic Capitalism in French Saint-Domingue and British Jamaica (Philadelphia: University of Pennsylvania Press, 2016), 5-6.

58. John D. Garrigus, Before Haiti: Race and Citizenship in French SaintDomingue (New York: Palgrave Macmillan, 2006), 195-226.

59. As shown by Carolyn Fick in The Making of Haiti: The Saint Domingue Revolution from Below (Knoxville: University of Tennessee Press, 1990), 9, one group "organized themselves in the hills outside of plantation society, elected themselves a king, and called the territory they occupied the Kingdom of Platons." 
independent nation, and supported political revolutions elsewhere in the Americas. ${ }^{60}$

In his book, Universal Emancipation (2008), Nick Nesbitt observes how "the Haitian Revolution created entirely new subjects of modernity" who "possessed often radically different visions of how the process of universal emancipation was to be implemented." ${ }^{61}$ What they envisioned, however, was not easy to achieve. Threatened with invasion by the European powers, the Haitian government had to maintain an army, which required money. It also had to pay an indemnity to French property owners. ${ }^{62}$ Burdened with debt, the government tried to expand the plantation economy. The people, however, wanted liberty, so they escaped into the countryside and lived as peasants. In addition to growing vegetables, they harvested coffee, which "became the basic means of exchange of the Haitian Republic," says Gusti-Klara Gaillard. "Twothirds was exported to French ports, enabling the young state to pay its external debt and trade with France.".63

60. Jean Fouchard, "Quand Haïti exportait la liberté," Revue de la Société Haïtienne d'Histoire et de Géographie, no. 143 (1984): 42-45.

61. Nick Nesbitt, Universal Emancipation: The Haitian Revolution and the Radical Enlightenment (Charlottesville: University of Virginia Press, 2008), 5-6.

62. Benoît Joaquim, Les racines de sous développement en Haïti (Port-auPrince: Henri Deschamps, 1979). Also see "Le néo-colonialisme à l'essai: la France et l'indépendance d'Haïti," an essay by Joaquim in La Pensée, no. 156 (1971): 35-51.

63. Gusti-Klara Gaillard, L'expérience haïtienne de la dette extérieure ou une production caféière pillée, 1875-1915 (Port-au-Prince: Henri Deschamps, 1990), 93. Pierre Benoît analyzes Haitian commerce in Cent cinquante ans de commerce extérieur d'Haïti, 1804-1954 (Port-au-Prince: Henri Deschamps, 
Although the peasantry escaped the plantation, they were unable to evade what Immanuel Wallerstein describes as the "modern world-system." The capitalist world-economy, Wallerstein expounds, systematically perpetuated "an axial division of labor" and "continuous exchanges of essential goods that are low-profit and highly competitive (i.e. peripheral) with high-profit and quasimonopolized (i.e. core-like) products." ${ }^{64}$ Like most nations in Latin America, Haiti was trapped in the "periphery." ${ }^{65}$ It lacked the necessary capital to industrialize and became increasingly dependent on trade with Western Europe ${ }^{66}$ As

1954). Also see Christian Girault, Le commerce du café en Haïti (Paris: Centre National de la Recherche Scientifique, 1981); Paul Moral, L'économie haïtienne (Port-au-Prince: Imp. de l'Etat, 1959).

64. Immanuel Wallerstein, The Modern World-System, vol. 3, The Second Era of Great Expansion of the Capitalist World-Economy, 1730s-1840s (Berkeley: University of California Press, 2011, originally published 1989), xiv.

65. André Gunder Frank, Capitalism and Underdevelopment in Latin America: Historical Studies of Chile and Brazil (New York: Monthly Review Press, 1969). Also see Dependency and Development in Latin America, trans. Marjory Mattingly Urquidi (Berkeley: University of California Press, 1979), in which Fernando Henrique Cardoso and Enzo Faletto look at various "situations of dependency" throughout Latin America.

66. The historiography on Haitian dependency includes Dumas Benjamin, Les conditions du développement économique d'Haïti (Port-au-Prince: Presses Nationales d'Haïti, 1977); Fred Doura, Economie d'Haïti: dépendence, crises et développement, 3 vols. (Montréal: Editions DAMI, 2003); Franz Douyon and Daniel Holly, Haïti de l'indépendence à la dépendence (Paris: L'Harmattan, 2004); Edouard Francisque, Perspectives du développement économique en Haïti (Port-au-Prince: Henri Deschamps, 1968); Charles Manigat, Claude Moïse, and Emile Olivier, Haiti: quel développement? (Montréal: Collectif Paroles, 1975). 
calculated by Victor Bulmer-Thomas, the Haitian government obtain nearly all its money, 99 percent, by taxing this exchange. ${ }^{67}$

Those who apply Marxist theory to Haiti emphasize how the modern world-system twisted the Haitian government into an oppressive apparatus that quashed the people's utopian dreams. In his book, Haiti: State Against Nation (1990), Michel-Rolph Trouillot explains how Haiti's "socioeconomic organization divided the nation sharply into two distinct groups," the "agricultural producers" and the "urbanites." ${ }^{\text {" }}$ The "urbanites," he states, included politicians, intellectuals, and merchants. They "persistently siphoned off the meager resources of the peasantry," which "came to finance the state while having no control over it." Scholars like Jean Jacques Honorat portray the "urbanites" as "compradors" (accomplices) who betrayed the nation to Western Europe simply to enrich themselves. ${ }^{69}$

In the mid-to-late nineteenth century, many urbanites envisioned a nation built upon technical knowledge; hence, Marxists associate technocracy with the modern world-system. An inconvenient truth, however, is that many urbanites

67. Victor Bulmer-Thomas, The Economic History of the Caribbean since the Napoleonic Wars (New York: Cambridge University Press, 2014), 163-68.

68. Michel-Rolph Trouillot, Haiti: State Against Nation. The Origins and Legacy of Duvalierism (New York: Monthly Review Press, 1990), 59, 80. Also see Gérard Pierre-Charles, L'économie haïtienne et sa voie de développement (Paris: G.P. Maisonneuve et Larose, 1967); Yves Montas (pseudonym Jean Luc), Structures économiques et lutte nationale populaire en Haïti (Montréal: Nouvelle Optique, 1974).

69. Jean Jacques Honorat, Enquête sur le développement (Port-au-Prince: Imp. Centrale, 1974). 
advocated autarky. Edmond Paul, who popularized the phrase, "power to the educated," insisted on Haiti's economic independence. ${ }^{70}$ Educated by the Collège Rollin in Paris (now named the Collège-Lycée Jacques-Decour), Paul wished to apply science and technology to create new businesses that would produce locally what Haiti normally imported..$^{71}$ Unlike the country's merchants, who wanted to increase trade with Western Europe, he enthusiastically supported an "industry creation" bill that banned various imports to protect the Haitian economy. ${ }^{72}$

In his book, From Dessalines to Duvalier: Race, Colour and National Independence in Haiti (1979), David Nicholls acknowledges the link between technocracy and autarky but implicates Edmond Paul in a milat conspiracy to dominate Haiti's black majority. Paul's conviction that "government must be entrusted to experts and technocrats" insinuated that "the masses [were] incapable of participating constructively in politics," says Nicholls. "This paternalistic Saint-Simonism" was an "enduring feature of the mulatto ideology

70. Edmond Paul, Les causes de nos malheurs (Port-au-Prince: Editions Fardin, 1976, originally published in 1882), 67.

71. Paul outlined his vision in Questions politico-économiques, vol. 2, Formation de la richesse nationale (Paris: Chez Meyrueis, 1863).

72. The "Ioi prescrivant des mesures pour la création des diverses industries" was published in the CEuvres posthumes d'Edmond Paul, vol. 1 (Paris: Chez Dunod \& P. Vicq, 1896), 310-22. 
through the nineteenth century into the twentieth." ${ }^{73}$ Because the milat minority was disproportionally well educated, Nicholls assumes that technocracy was merely a pretext to marginalize blacks. His theory, however, has one obvious weakness: Paul was black, not milat.

Nicholls' statement on "mulatto ideology" was not unprecedented. In a classic study, La vocation de l'élite (1917), the top authority on ethnography in Haiti, Jean Price-Mars, lamented how the milat minority disavowed the country's African inheritances and associated themselves with Western Europe.$^{74}$ They dressed in French clothes; spoke in French; and embraced French philosophy. ${ }^{75}$ Price-Mars described the phenomenon as "bovarism," i.e. "cultural alienation."76 The elite, he explained, internalized the stereotype that non-white populations are ignorant; hence, they went to universities in Western Europe, like the Collège

73. David Nicholls, From Dessalines to Duvalier: Race, Colour and National Independence in Haiti (New Brunswick: Rutgers University Press, 1996, originally published in 1979), 102-107.

74. Jean Price-Mars, La vocation de l'élite (Port-au-Prince: Presses Nationales d'Haïti, 2001, originally published in 1919), iii-iv.

75. Patrick Bellegarde-Smith examines the elite's interest in France in "Haitian Social Thought in the Nineteenth Century: Class Formation and Westernization," Phylon 42, no. 3 (Fall 1981): 233-44.

76. In his book, The Imagined Island: History, Identity, and Utopia in Hispaniola, trans. Jane Ramírez (Chapel Hill: University of North Carolina Press, 2005), 69, Pedro L. San Miguel explains how "Price-Mars coined the term 'collective bovarism' to describe the propensity of the lettered and dominant sectors in Haiti for identifying themselves culturally with Europe while denying or ignoring their African legacy." 
Rollin. ${ }^{77}$ Upon return, they advocated "power to the educated," but they hardly knew the people they wished to lead. ${ }^{78}$

As noted by Price-Mars, the tension between the Haitian government and the people led to political instability, US intervention, and oppression. In the early twentieth century, the US invested heavily in the Haitian economy. ${ }^{79}$ Hence, when President Vilbrun Guillaume Sam was slain by an angry crowd in 1915, the US invaded the country to protect its property. Between 1915 and 1934, the Marines Corps tyrannized the Haitian people. It commandeered the government; organized a gendarmerie; and suppressed a provincial insurgency, killing between 3,000 and 11,500 people.$^{80}$ It imposed a corvée on the peasantry to build a highway system that would enable the new gendarmerie to police the countryside. It also pressured the Haitian government to amend the constitution

77. Laënnec Hurbon analyzes this stereotype in La barbare imaginaire (Portau-Prince: Henri Deschamps, 1987), 12-14.

78. Price-Mars, La vocation de l'élite, 73-74.

79. Alain Turnier examines US investment in Les États-Unis et le marché haïtien (Montréal: Imp. Saint-Joseph, 1955), 233-304. Also see Roger Gaillard, La république exterminatrice, 7 vols. (Port-au-Prince: Imp. Natal, 1998); Leslie Manigat, "La substitution de la prépondérance américaine à la prépondérance française en Haïti au début du XXe siècle," Revue d'histoire moderne et contemporaine 14, no. 4 (Oct.-Dec. 1967): 321-55.

80. Roger Gaillard documents these events in Le blanques débarquent, 7 vols. (Port-au-Prince: Imp. Natal, 1973-1981). Also see Mary A. Renda, Taking Haiti: Military Occupation and the Culture of US Imperialism, 1915-1940 (Chapel Hill: University of North Carolina Press, 2001); Hans Schmidt, The United States Occupation of Haiti, 1915-1934 (New Brunswick: Rutgers University Press, 1995). 
so that non-Haitians could buy land without a concession. As a result, Haiti was pulled further into the capitalist world-economy. ${ }^{81}$

Many people associate technocracy with the Marine occupation because the US actively trained Haitian technicians. As explained by Léon D. Pamphile, the US instituted a "Service Technique," which included 19 vocational schools and the "Ecole Centrale," a college in Damien, six miles outside Port-au-Prince. ${ }^{82}$ Led by a Texan named George Freeman, the Service was a lot like vocational establishments in the southern US, where African Americans were socialized to "work with the hands." Many graduates, however, were invited to Ivy League universities, where they studied public administration. They usually returned to Haiti with a grand vision to improve the country, says Charles Pierre-Jacques, but they were seen as compradors. ${ }^{83}$ Opponents called them "les maîtres," i.e. "the masters," to mock their academic degrees and implicate them in a conspiracy to enslave the Haitian people.

In summation, the historiography on Haiti generally portrays technocracy as the antithesis of a just society. It emphasizes how those with technical knowledge became entangled in world-systems, class structures, ideological

81. Suzy Castor, L'occupation américaine d'Haïti (Port-au-Prince: Henri Deschamps, 1987).

82. Léon D. Pamphile, L'éducation en Haïti sous l'occupation américaine, 19151934 (Port-au-Prince: Imp. des Antilles, 1988).

83. In his book, D'Haïti à l'Afrique: itinéraire de Maurice Dartigue, un éducatteur visionnaire (Montréal: Editions Images, 2002), Charles Pierre-Jacques looks at Maurice Dartigue, a student who enrolled at the Ecole Centrale in 1924 then went to Columbia University in New York. 
superstructures, and imperialism. No doubt, it exposes many unsavory truths about technocracy. Nevertheless, its preoccupation with structuralism is problematic. As noted by Gilbert Joseph, "the comprador bourgeoisie," which included Haitian technicians, is believed to have "lacked a true consciousness," since "[its] interests and tastes were essentially those of metropolitan capital [and] not [its] own." ${ }^{84}$ Meanwhile, the "peasants and urban masses [have been] viewed as displaced subjects, less a part of history than its victims." They simply "waited on the sidelines for the transformative social project that would initiate them into the adventure of development."

\section{Technocracy in the Cold War Era}

The historiography on the Global Cold War portrays technocracy in much the same way as that on Haiti. Technicians are normally presented as zealots who colluded with brutal despots to maintain the modern world-system. As proclaimed by William Appleman Williams in The Tragedy of American Diplomacy (1959), "what we are accustomed to call[ing] the Cold War [was] in reality only the most recent phase of a more general conflict between the established system of Western capitalism and its internal and external

84. Joseph, "Close Encounters," 12-13. 
opponents." ${ }^{85}$ According to Williams, policymakers in Washington sponsored oppressive governments to contain Soviet ideology then dispatched technicians to build the "high mass-consumption" utopia envisioned by Walt W. Rostow.

Historians who support Williams' hypothesis in The Tragedy of American Diplomacy usually emphasize how Washington embraced autocracy in Latin America. In his book, Inevitable Revolutions (1983), Walter LaFeber explains how the "military-oligarchy complex" was "its best bet to maintain the system" and "protect North American assets," especially in Central America, where Marxist insurgency threatened US hegemony. ${ }^{86}$ Hence, the US backed conservative governments and turned a blind eye when they violently quashed anyone who opposed the capitalist world-economy. ${ }^{87}$ "The killings were brutal beyond imagination," says Greg Grandin. "Soldiers murdered children by beating

85. William Appleman Williams, The Tragedy of American Diplomacy (New York: W.W. Norton \& Company, 1962, originally published in 1959), 10.

86. Walter LaFeber, Inevitable Revolutions: The United States in Central America (New York: W.W. Norton \& Company, 1983), 112. Also see Lloyd C. Gardner, Imperial America: American Foreign Policy since 1898 (New York: Harcourt Brace, 1976); Gabriel Kolko, Confronting the Third World: United States Foreign Policy, 1945-1980 (New York: Pantheon, 1988).

87. As noted by Leslie Bethell and lan Roxborough in "The Impact of the Cold War on Latin America," in Origins of the Cold War: An International History, eds. Melvyn P. Leffler and David Painter (New York: Routledge, 1994), 311, "the United States approved of, where it was not actively involved in, [a] general shift to the right... in Brazil as early as 1945, Bolivia, Chile, and Ecuador in 1946-7, Cuba in 1947-8," and "Venezuela and Peru in 1948." 
them on rocks." They "extracted organs and fetuses, amputated genitalia and limbs, committed mass and multiple rapes, and burned some victims alive." ${ }^{\text {} 8}$ While the historiography on Haiti generally upholds Williams' hypothesis, some alternations were necessary to explain the Duvaliers' origin. According to Michel-Rolph Trouillot, "the Duvaliers emerged as the result of a long-term process that was marked by an increasing disjuncture between political and civil society" brought about by the capitalist world-economy. ${ }^{89}$ François Duvalier manipulated the tension between the country's black majority and the predominantly milat oligarchy to seize both the presidency and the military complex built by the US occupation in the early twentieth century. ${ }^{90} \mathrm{He}$ then outlawed communism and persecuted the Parti Unifié des Communistes Haïtiens (PUCH) to win US support. In 1959, the US dispatched a Naval Mission led by Lieutenant Robert Heinl to strengthen the Haitian military. In his book, Written in

88. Greg Grandin, The Last Colonial Massacre: Latin America in the Cold War (Chicago: University of Chicago Press, 2004), 3. Also see Hal Brands, Latin America's Cold War (Cambridge: Harvard University Press, 2010); Stephen G. Rabe, The Killing Zone: The United States Wages Cold War in Latin America (New York: Cambridge University Press, 2011).

89. Trouillot, Haiti: State Against Nation, 15. In his book, The Roots of Haitian Despotism (Boulder: Lynne Rienner, 2007), Robert Fatton, Jr. explains how this "disjuncture" cultivated an "authoritarianism habitus" that culminated in Duvalierism. Also see Patrick Bellegarde-Smith, "Class Struggle in Contemporary Haitian Politics: An Interpretive Study of the Campaign of 1957," Journal of Caribbean Studies 2, no. 1 (Spring 1981): 109-27; Alex Dupuy, "Conceptualizing the Duvalier Dictatorship," Latin American Perspectives 15, no. 4 (Fall 1988): 105-14.

90. David Nicholls, "Haiti: The Rise and Fall of Duvalierism," Third World Quarterly 8, no. 4 (Oct. 1986): 1239-52. 
Blood (1978), Heinl explains how François Duvalier "divert[ed] what few arms and ammunition the US military mission had actually furnished the army into his milice," which used them to terrorize the Haitian people. ${ }^{91}$

While the US sponsored violent dystopias throughout Latin America, it also promoted "modernization" and "high mass-consumption" to win back hearts and minds. Policymakers developed what Frank A. Ninkovich describes as "cultural relations." They incorporated Hollywood movies, Coca-Cola, and kitchen appliances into propaganda that would "reorient individuals through the noncoercive, rational implantation of ideas. ${ }^{\prime 92}$ As documented by Christian Alcindor, President Kennedy wished to implant both "modernization" and "high mass-consumption" in Haiti to prevent a second Cuban Revolution. He also intended to use "modernization" in Haiti as propaganda to convince nations in Africa that the US government supports non-white populations, despite evidence to the contrary exposed by the African-American Civil Rights Movement. ${ }^{93}$

91. Robert Debs Heinl and Nancy Gordon Heinl, Written in Blood: The Story of the Haitian People, 1492-1971 (Lanham: University Press of America, 2005, originally published in 1978), 568.

92. Frank A. Ninkovich, The Diplomacy of Ideas: US Foreign Policy and Cultural Relations, 1938-1950 (New York: Cambridge University Press, 1981), 181. Exemplary works on propaganda in the Cold War era include Laura A. Belmonte, Selling the American Way: US Propaganda and the Cold War (Philadelphia: University of Pennsylvania Press, 2008); Walter L. Hixon, Parting the Curtain: Propaganda, Culture, and the Cold War, 1945-1961 (New York: St. Martin's Press, 1997); Reinhold Wagnleitner, Coca-Colonization and the Cold War: The Cultural Mission of the United States in Austria After the Second World War (Chapel Hill: University of North Carolina Press, 1994).

93. Christian Alcindor, "United States-Haiti Relations from 1957 to 1963: Anticommunism, Nation-Building, and Racial Diplomacy in the Age of National 
Troubled by the Tonton Macoutes, however, Kennedy did not invite Haiti to participate in the "Alliance for Progress," his grand initiative to "modernize" Latin America. ${ }^{94}$

Nevertheless, many scholars believe that Haiti was bewitched by highmodernist ideology. In his book, Penser le développement (1979), Rony Durand bemoans how the country's best technicians went to universities in the US, where they "trained as parrots" to apply "Western ideology" to Haiti. ${ }^{95}$ According to Durand, they were made to think that Haiti was "undeveloped" because it lacked technical knowledge, when in reality, "underdevelopment was caused by the capitalist world-economy." ${ }^{96}$ Achille Aristide makes the same point in Culture, civilisation et développement (1978). "Western ideology," Aristide avers, "penetrated the doctrines, theories, and practices of development" in Haiti. Like a new "bovarism," modernization theory "became integral to the mentality,

Liberation (Ph.D. Dissertation: Rutgers University, 2002). Thomas Borstelmann analyzes how the Civil Rights Movement shaped US diplomacy in The Cold War and the Color Line: American Race Relations in the Global Arena (Cambridge: Harvard University Press, 2001). Also see Mary L. Dudziak, Cold War Civil Rights: Race and the Image of American Democracy (Princeton: Princeton University Press, 2000); Penny Von Eschen, Satchmo Blows Up the World: Jazz Ambassadors Play the Cold War (Cambridge: Harvard University Press, 2006).

94. Wien Weibert Arthus, "The Alliance for Progress: A Case Study of Failure of International Commitments to Haiti," in The Idea of Haiti: Rethinking Crisis and Development, ed. Millery Polyné (Minneapolis: University of Minnesota Press, 2013).

95. Rony Durand, Penser le développement (Port-au-Prince: Editions Fardin, 1979), 30-31.

96. Ibid., 39. 
personality, and professional consciousness of experts, technical advisors, and agents of development." ${ }^{\prime 97}$

As a whole, the historiography on the Cold War era emphasizes how technicians were tangled up in political, economic, and ideological structures that suppressed the utopian impulse. It exposes numerous obstacles to a just society in Latin America but denies technicians the ability to think independently. In a landmark study, In From the Cold: Latin America's New Encounter with the Cold War (2008), Gilbert Joseph and Daniela Spencer bewail "the manner in which foreign relations historians have assessed the [Cold War] in terms of national interest, state policy, and broad imperatives of the international economy." This approach, they explain, "has often marginalized human subjects," such as technicians, "ignoring a serious examination of their social and cultural identities and political agency." ${ }^{98}$

Max Paul Friedman, meanwhile, questions the assumption that Latin American elites were mindless marionettes. "We must strike a balance [between structure and agency]," Friedman argues, "by acknowledging the enormous

97. Achille Aristide, Culture, civilisation et développement (Port-au-Prince: Henri Deschamps, 1978), 147. Also see Emerson Douyon, ed., Culture et développement en Haïti (Ottawa: Editions Leméac, Inc., 1972); J. B. Roumain, ed., La stratégie du développement national et dimension culturelle (Port-auPrince: Imp. M. Rodriguez, 1982); Yves Saint-Gérard, Haïti: l'enfer au paradis. Mal développement et troubles de l'identité culturelle (Toulouse: Editions Eché, 1984).

98. Gilbert M. Joseph and Daniela Spencer, eds., In From the Cold: Latin America's New Encounter with the Cold War (Durham: Duke University Press, 2008), 17. 
impact of the Western Hemisphere's only superpower without ignoring the role of Latin American [leaders] in shaping their own history." ${ }^{" 99}$ Inspired by Friedman, many historians now support the "pericentric" approach to the Cold War outlined by Tony Smith in Diplomatic History. Smith accentuates how "junior members in the periphery" commonly "manipulated" the US and the USSR, "giv[ing] the Cold War the character it came to have." Latin American elites, he explains, were less puppets than "determined nationalists, hardened realists, principled idealists, high-rolling risk takers, committed ideologs, brazen manipulators, and opportunists able to use the world crisis for their own ends." 100

This was certainly the case in Haiti, where both policymakers and planners navigated US diplomacy to pursue what they desired. As shown by Wien Weibert Arthus in Duvalier à l'ombre de la guerre froid (2014), Haiti's top policymaker, François Duvalier, exploited the Cuban Revolution to obtain US assistance and consolidate his authority. "Duvalier's foreign policy," Arthus notes, "changed according to the administration in place and the needs of the

99. Max Paul Friedman, "Retiring the Puppets, Bringing Latin America Back In," Diplomatic History 27, no. 5 (Nov. 2003): 621-36.

100. Tony Smith, "New Bottles for New Wine: A Pericentric Framework for the Study of the Cold War," Diplomatic History 24, no. 4 (Oct. 2000): 568-70, my own emphasis. Pericentrist historiography includes Zachary Karabell, Architects of Intervention: The United States, the Third World, and the Cold War, 1945-1962 (Baton Rouge: Louisiana State University Press, 1999); Jadwiga E. Pieper Mooney and Fabio Lanza, eds., De-Centering Cold War History: Local and Global Change (New York: Routledge, 2012); Kathryn C. Statler and Andrew L. Johns, eds., The Eisenhower Administration, the Third World, and the Globalization of the Cold War (Lanham: Rowman \& Littlefield, 2006). 
moment." ${ }^{101}$ Arthus documents Duvalier's ingenuity. Paradoxically, however, he denies this agency to everyone else. "To study Haiti in the time of Duvalier," he claims, "is to study Duvalier lui-même," because "the chief executive is an allpowerful personality." ${ }^{102}$ While no one questions the Duvaliers' place in Haitian history, Arthus underestimates Haitian technicians, who envisioned a just society based on liberty and equality.

My dissertation moves beyond presidential politics to analyze the plans implemented by technicians. It delves into the private correspondence between Haitian and non-Haitian specialists to expose the utopian impulse. First, I survey regional planning in the Artibonite Valley. I investigate how Haitian and USG technicians hoped to balance science and technology with community organization and conservation to create a pastoral paradise. Second, I inspect family planning in Fond Parisien, a tiny settlement in the countryside. I analyze how Haitian physicians and US missionaries promoted Western medicine and contraception to pioneer a "third way" to prosperity. Third, I look at urban planning and explain how Haitian technicians and UN specialists intended to build garden cities outside Port-au-Prince. Fourth, I assess central planning and evaluate the alternative vision proposed by Haitian technicians, local businessmen, and multinational corporations.

101. Wien Weibert Arthus, Duvalier à l'ombre de la guerre froide: les dessous de la politique étrangère d'Haïti, 1957-1963 (Port-au-Prince: Imp. S.A., 2014), 29. 102. Ibid., 33-34. 
Throughout my dissertation, I expose the tension between policymakers, technicians, and the Haitian people that undermined technocracy. Finally, in the conclusion, I explain how the technicians' inability to solve Haiti's problems led to widespread disillusionment. 


\section{REGIONAL PLANNING IN THE ARTIBONITE VALLEY}

"The Haitian peasant has handled our agriculture... as best... he could," stated Marc Holly in 1953. "At present," however, "the pressure on the land is relatively great and is increasing," due to soil erosion and population growth. As a local technician, Holly was deeply concerned. "There [is] never [any] patriotic enthusiasm... to do anything serious for the welfare of the peasants," he complained. Upset by his country's "lack of vision," he proposed regional

planning. " "With adequate engineering," he explained, "[the nation's rivers] could be made to irrigate the plains and valleys." The Haitian "countryside could be... beautiful!" Valley development was no easy task. It "even seems utopian!" Holly laughed. Nevertheless, "it must be faced squarely!"

Holly was prepared to lead the way. Born in Cap-Haïtien in 1912, he learned agronomy at the Ecole Centrale in Damien (Fig. 3). He then went to Hampton Institute, a historically black college in Virginia, where he specialized in agricultural education. In both Haiti and the US, he was trained to "work with the

1. Marc Holly, Agriculture in Haiti (New York: Vantage, 1955), 35-6, 217-19.

2. As explained by Robert Fishman in The American Planning Tradition: Culture and Policy (Baltimore: Johns Hopkins University Press, 2000), 12-14, regional planning divides the nation into regions based on geography. It then builds upon each region's local culture and natural resources. 


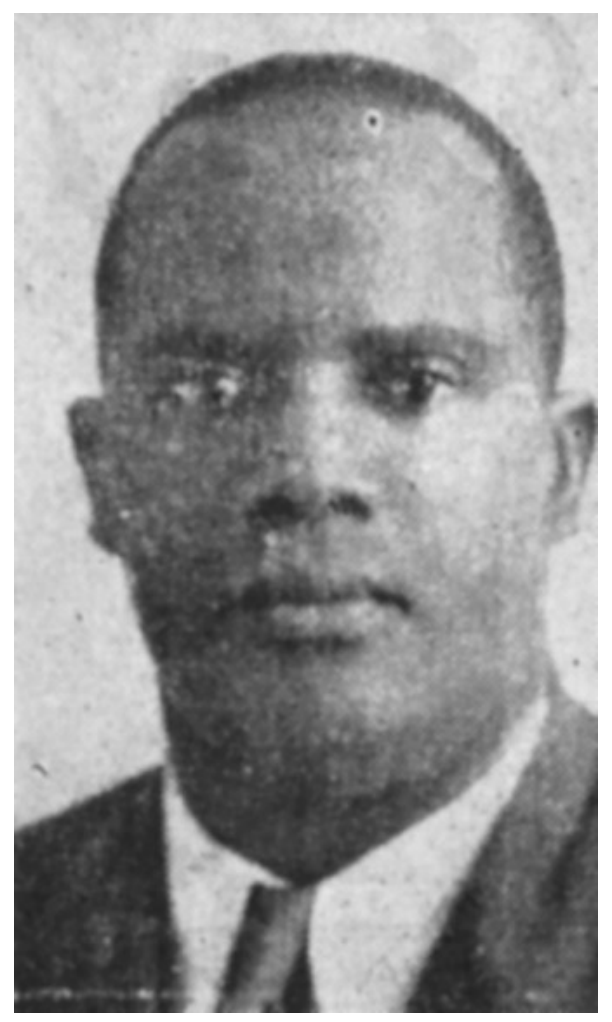

Fig. 3 Marc Holly, Co-Chairman of the Organisation de Développement de la Vallée de l'Artibonite. From: Haiti Sun (2 October 1955): 10. Reproduced with permission.

hands," but he would not have it any other way. ${ }^{3} \mathrm{He}$ agreed with Hampton's renowned alumnus, Booker T. Washington, that "no race can prosper till it learns that there is as much dignity in tilling a field as in writing a poem." ${ }^{4}$

3. In his book, The Education of Blacks in the South, 1860-1935 (Chapel Hill: University of North Carolina Press, 1988), 33-40, James D. Anderson describes how Hampton Institute socialized newly-emancipated African Americans to dedicate themselves to manual labor.

4. Booker T. Washington, "Atlanta Exposition Address" (18 September 1985), in The Booker T. Washington Papers, ed. Louis R. Harlan, vol. 3 (Urbana: University of Illinois Press, 1974), 584-87. Also see "On American Occupation," vol. 13, 396-99, in which Washington advocated vocational education in Haiti. 
Eager to apply what he had learned, Holly seized the opportunity to lead the new Organisation de Développement de la Vallée de l'Artibonite (ODVA) in 1949. Sponsored by the Export-Import Bank of the United States, the ODVA was a corporation, wholly owned by the Haitian government. Its task was to carry out regional planning in the Artibonite Valley, a $300 \mathrm{mi}^{2}$ territory that surrounds the Artibonite River in both the Central and Artibonite provinces. Aided by USG technicians, Holly and his co-chairman, Alcide Duviella, hauled in bulldozers and harvesters, plows and planters, threshers and tractors. They excavated irrigation canals and installed pumps on the valley's waterways.

Although the ODVA invested heavily in technology, it was not simply an extension upon high-modernist ideology. Holly and his associates were independent thinkers who tried to balance technical knowledge with community organization and conservation. As Holly explained, "technical methods" were "indispensable," but they were only "a partial and very incomplete solution." Regional planning, he argued, would have to develop the peasantry's timehonored practices, especially "benevolent cooperation," hard work, and "self help." Inspired by populism in the US, communitarianism in Western Europe, and Indigenismo in Latin America, Holly and Duviella envisioned what Leo Marx describes as the "middle landscape," an alternative modernity in which science and industry accommodate the "pastoral ideal."

5. Holly, Agriculture in Haiti, 165.

6. Leo Marx, The Machine in the Garden: Technology and the Pastoral Ideal in America (New York: Oxford University Press, 2000, originally published in 1964). 
Unable to proceed on his own, Holly turned to the Institute of InterAmerican Affairs (IIAA), a US government agency that preceded the ICA and USOM. He noted how IIAA technicians had been in the Artibonite Valley since 1946. They had already organized a "Food Supply Mission" and a "Cooperative Service" to support the local peasantry. Much to Holly's delight, the IIAA welcomed the ODVA, which it envisioned as the next Tennessee Valley Authority (TVA). Founded in 1933, the TVA was a "government corporation" that introduced "modern technology beside the immemorial culture of the indigenous." ${ }^{\prime 7}$ It built 20 hydroelectric dams in the Tennessee Valley, a $458 \mathrm{mi}^{2}$ plain that stretches across Alabama, Kentucky, Georgia, North Carolina, Tennessee, and Virginia. It also promoted "grassroots democracy" and environmental conservation.

Technology has been a common theme in both literary and physical utopias since early modern times, and it was undoubtedly a key component of the ODVA. ${ }^{8}$ The technicians' insistence upon a "middle landscape," however,

Howard P. Segal analyzes the "middle landscape" in both Technological Utopianism in American Culture (Chicago: University of Chicago Press, 1985), 94-97, and "Leo Marx's 'Middle Landscape:' A Critique, a Revision, and an Appreciation," Reviews in American History 5, no. 1 (Mar. 1977): 137-50.

7. William Jordy, "Symbolic Essence" and Other Writings on Modern Architecture and American Culture (New Haven: Yale University Press, 2005), 106-107.

8. Ernst Bloch examines various "technological utopias" in The Principle of Hope, vol. 2, 625-98. Also see René Jules Dubos, The Dreams of Reason: Science and Utopias (New York: Columbia University Press, 1961); Nell Eurich, Science in Utopia: A Mighty Design (Cambridge: Harvard University Press, 
belies the assumption that technocracy was captivated by high-modernist ideology. In the book, Modernization as Ideology (2000), Michael Latham says that USG technicians were motivated by modernization theory to spread science and technology throughout the world. ${ }^{9}$ David Ekbladh makes the same point in The Great American Mission (2011). Ekbladh associates the TVA and its progeny with "modernization" and discounts the technicians' emphasis on grassroots democracy as empty "rhetoric." 10 The ODVA, however, exposes the centrality of community organization to the technicians' utopian vision. As stated by Daniel Immerwahr in Thinking Small: The United States and the Lure of Community Development (2015), "we must allow ourselves to see that our past contains not just the urge to modernize but the quest for community as well." ${ }^{11}$

The ODVA's sympathy toward the peasantry also contradicts the historiography on Haiti. Most scholars emphasize how elites looked down upon

1967); Mulford Q. Sibley, Technology and Utopia Thought (Minneapolis: Burgess, 1971).

9. Latham, Modernization as Ideology, 5-6.

10. David Ekbladh, The Great American Mission: Modernization and the Construction of an American World Order (Princeton: Princeton University Press, 2011), 11-13. Also see James C. Scott, "High Modernist Social Engineering: The Case of the TVA," in Experiencing the State, eds. Lloyd I. Rudolph and John Kurt Jacobson (Delhi: Oxford University Press, 2007).

11. Daniel Immerwahr, Thinking Small: The United States and the Lure of Community Development (Cambridge: Harvard University Press, 2015), 13. Also see When the Hands Are Many: Community Organization and Social Change in Rural Haiti (Chapel Hill: University of North Carolina Press, 2001), 4, in which Jennie M. Smith analyzes how "community organization" was important to America's "vision of a good society" in Haiti. 
the peasants. ${ }^{12}$ Those who apply dependency theory and world-systems theory to Haiti also bemoan how technicians previously colluded with the US to exploit them. ${ }^{13}$ In his book, Haiti in the World Economy (1986), Alex Dupuy notes how the Standard Fruit and Steamship Company monopolized the banana industry in the Artibonite Valley between 1934 and $1946 .{ }^{14}$ He also mentions the Société Haïtiano-Américaine Développement Agricole (SHADA), a government corporation instituted by President Elie Lescot in 1941. Funded by the ExportImport Bank, SHADA seized the peasants' land and bulldozed nearly $80 \mathrm{mi}^{2}$ to grow cryptostegia. As explained by Marcel B. Auguste, cryptostegia yields latex, a commodity that was needed by the US military during WWII. ${ }^{15}$

Unlike SHADA, the ODVA wished to protect the peasantry and create a pastoral utopia. In the end, however, Holly and his associates were unable to subjugate the political and economic interests behind modernization theory. Threatened by Soviet expansion, the Department of State and the US military

12. Price-Mars, La vocation de l'élite. Also see Gérard Barthélemy, L'univers rural haïtien: le pays en dehors (Paris: L'Harmattan, 1990); Jean Jacques Honorat, Le manifete du dernier monde (Port-au-Prince: Henri Deschamps, 1980); Paul Moral, Le paysan haïtien: étude sur la vie rurale en Haïti (Paris: G.P. Maisonneuve et Larose, 1961).

13. Gérald Brisson and Gérard Pierre-Charles, Les relations agraires dans l'Haïti contemporaine (Port-au-Prince: N.p., 1968).

14. Alex Dupuy, Haiti in the World Economy: Class, Race, and Underdevelopment since 1700 (Boulder: Westview Press, 1989), 144.

15. Marcel B. Auguste, La république d'Haïti et la deuxième guerre mondiale (Québec: AGMV Marquis, 1988). 
invested a vast sum in private contractors who specialized in "modernization."16

As a result, corporations like Knappen-Tippetts-Abbett (KTA) had a privileged say in Washington. KTA was able to persuade both the Export-Import Bank and the Haitian government to sanction a special "Planning Group," whose authority trumped the ODVA. Uninterested in the "middle landscape," the Planning Group insisted that Haiti abandon Holly's vision and build the massive Péligre Dam in the mountains above the valley. ${ }^{17}$

Weakened by the Planning Group, the ODVA crumbled when François Duvalier seized the presidency in 1957. Duvalier harassed independent-minded technicians. He dismissed Holly's pastoral vision and invested everything in a new Centrale Hydro-Electrique beside the Péligre Dam. It was Duvalier's conviction that technology would spark "modernization" and legitimize

16. In the book, Armed with Expertise: The Militarization of American Social Research during the Cold War (Ithaca: Cornell University Press, 2013), Joy Rodhe outlines a "military-academic-industrial complex" that promoted "modernization." Also see "From Expert Democracy to Beltway Banditry: How the Antiwar Movement Expanded the Military-Academic-Industrial Complex," an essay by Rodhe in Cold War Social Science: Knowledge Production, Liberal Democracy, and Human Nature, eds. Mark Solovey and Hamilton Cravens (New York: Palgrave Macmillan, 2012), 137-54.

17. Leslie J.R. Péan describes the Péligre Dam as "the climax of corruption" in Haïti: économie politique de la corruption, vol. 3, Le saccage, 1915-1956 (Paris: G.P. Maisonneuve et Larose, 2006), 483. Rony Durand makes the same point in Regards sur la croissance économique d'Haïti (Port-au-Prince: Imp. des Antilles, 1965), 117. Also see Ernst A. Bernardin, L'espace rural haïtien: bilan de 40 ans d'exécution des programmes nationaux et internationaux de développement, 1950-1990 (Paris: L'Harmattan, 1993), 100-103; Wolf Donner, Ayiti: potansyèl natirèl e Dèvlopman (Fribourg: Komité EdiKréyòl, 1982), 329. 
authoritarianism. In reality, however, it betrayed the utopian impulse that originally inspired the ODVA and hastened the peasantry's economic decline.

\section{The Valley Plan}

The ODVA, like the TVA, evolved within a transnational movement that linked American populism to communitarianism in Western Europe and Indigenismo in Latin America. This movement dates back to the late nineteenth century, when the Second Industrial Revolution provoked animosity in the southern and midwestern United States. Between 1877 and 1889, the National Farmers' Alliance, the National Farmers' Alliance and Industrial Union, and the Colored Farmers' National Alliance and Cooperative Union mobilized the countryside to protect the region's agricultural economy. ${ }^{18}$ Throughout the Midwest, communities also organized youth clubs, such as "4-H," to promote pastoral values. 4-H provided a preliminary vocational education to children who pledged head, heart, hands, and health to the club, the community, and the country. ${ }^{19}$

18. Charles Postel, The Populist Vision (New York: Oxford University Press, 2007), 103-33.

19. As explained by Amrys O. Williams in "Cultivating Modern America: 4-H Clubs and Rural Development in the Twentieth Century" (Ph.D. Dissertation: University of Wisconsin, Madison, 2012), 4-H was incorporated into the US government by the Department of Agriculture in 1914. 
As populism swept across the US, communitarianism spread in Western Europe. In 1895, various cooperatives convened in London, where they united to create the International Co-operative Alliance. The Alliance embraced the "utopian socialism" pioneered by Welsh communitarian Robert Owen in the early nineteenth century. ${ }^{20}$ It even adopted the principles introduced by the Society of Equitable Pioneers in Rochdale, England. Inspired by Owen, the Equitable Pioneers produced basic commodities, like candles and clothing, which they themselves consumed. Much like the Pioneers, the Alliance had open membership and insisted on democracy and equality. ${ }^{21}$

Meanwhile, credit unions had taken Europe by storm. Marc Holly observed how they "are spread by hundreds of thousands in various countries, such as Switzerland, Belgium, [and] Holland."22 When Holly visited Europe in 1946, he was especially impressed by the Raiffeisen cooperatives. "The Raiffeisen Credit Co-operative was initiated in Germany in 1849 by Friedrich Wilhelm Raiffeisen, German burgomaster of a group of villages around Neuwald," Holly explained. "The first important principle of the movement was that improvement must start at the bottom, from the people themselves; the second [was] that morality is

20. Daniel T. Rodgers, Atlantic Crossings: Social Politics in a Progressive Age (Cambridge: Belknap Press, 2000), 318-42.

21. John F. Wilson, Anthony Webster, and Rachael Vorberg-Rugh analyze the Rochdale principles in Building Co-operation: A Business History of the CoOperative Group, 1863-2013 (New York: Oxford University Press, 2013), 34-41.

22. Holly, Agriculture in Haiti, 238-41. 


\section{THEASBOCIATIOM OFTHEVALLEY.PLANWITH THEYALLEY SECTION}

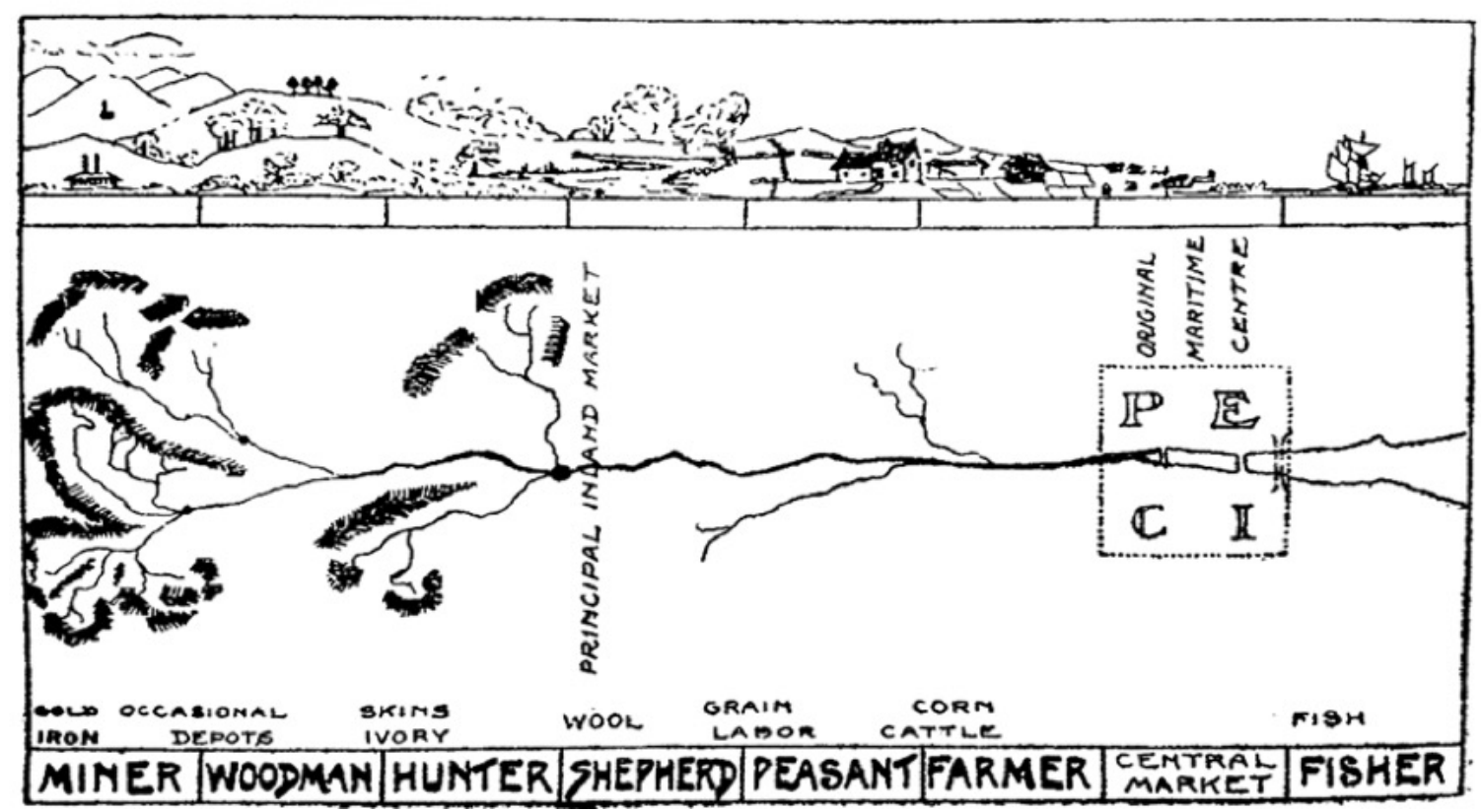

Fig. 4 The Association of the Valley Plan with the Valley Section. From: The Coming Polity (London: Williams \& Norgate, 1919) by Patrick Geddes and Victor Branford.

essential." Holly took detailed notes. "It appears that the 'Raiffeisen' type of cooperation... would be the ideal system for us [Haitians]," he wrote.

Europe was home to not only a vibrant cooperative movement but also the "valley plan." Introduced by the Scottish evolutionist, Patrick Geddes, the plan took a hypothetical valley and divided the inhabitants into occupations based on the region's natural resources (Fig. 4). ${ }^{23}$ Geddes wanted specialists to survey the

23. "Patrick Geddes," in Utopias and Utopians: A Historical Dictionary, ed. Richard C.S. Trahair (Westport: Greenwood Press), 153-54. Also see W.H.G. Armytage, Heavens Below: Utopian Experiments in England, 1560-1960 (New York: Routledge, 2006, originally published in 1961); Helen Meller, Patrick Geddes: Social Evolutionist and City Planner (New York: Routledge, 1990). 
valley and make decisions accordingly. Inspired by anarchists Peter Kropotkin and Eliseé Réclus, however, he then wanted the specialists to step away, so the community could govern the region independently, as a cooperative. TVA chairman Gordon Clapp noted how the "valley region" has "common resources, common problems, and common aims.... From similarities a sense of cultural neighborhood emerges" with "unity... in a common cause for work and action."24

The valley plan crossed the Atlantic in 1923, when town planners and conservationists organized the Regional Planning Association of America (RPAA). Led by Geddes' disciple, Lewis Mumford, the RPAA embraced the valley plan as a "bridge by which the specialist... and the active worker... may come into contact." From this contact, Mumford proclaimed, "our plans and our utopias may be founded on... a permanent foundation," since "the sciences themselves will be cultivated with some regard for human values and standards, as embodied in the needs and ideals of the local community." ${ }^{25}$ The RPAA promoted the valley plan as a means to subordinate technology to the environment and its human inhabitants. ${ }^{26}$ Aptly stated by RPAA conservationist

24. Gordon R. Clapp, "The Tennessee Valley Authority," in Regionalism in America, ed. Merrill Jensen (Madison: University of Wisconsin Press, 1951), 32627.

25. Lewis Mumford, The Story of Utopias (New York: Boni \& Liveright, 1922), 281.

26. Edward K. Spann, Designing Modern America: The Regional Planning Association of America and Its Members (Columbus: Ohio State University Press, 1996). Also see Robert Dorman, Revolt in the Provinces: The Regionalist Movement in America, 1920-1945 (Chapel Hill: University of North Carolina 
Benton MacKaye, "nature had molded the country in a certain way," and each planner's task was to "uncover nature's plan." ${ }^{27}$

In Haiti, meanwhile, the Ecole Centrale proposed its own valley plan. In 1926, it surveyed the Artibonite Valley. Upon analyzing various soil samples, it discovered that the land was exceptionally fertile but dry. ${ }^{28}$ Marc Holly studied the survey. "The plain," he explained, was "semiarid, not because of lack of rainfall, but because of many other climate factors, chiefly the bad distribution of rainfall... low humidity... the intensity of the sun's rays, and the velocity of the winds," which exacerbated water evaporation. ${ }^{29}$ Back in the early 1700 s, the French had built a canal system to irrigate the valley, but it was destroyed by a massive flood in $1761 .^{30}$ The Ecole Centrale outlined a new system that would cost an estimated 2.3 million US dollars. The Haitian government, however, was short on money, so the plan was shelved.

This is not to say that Haitians gave up on the countryside. To the contrary, many intellectuals insisted that technicians protect the peasantry. In

Press, 1993); Mark Luccarelli, Lewis Mumford and the Ecological Region: The Politics of Planning (New York: Guilford Press, 1995).

27. Benton MacKaye, The New Exploration: A Philosophy of Regional Planning (Urbana: University of Illinois Press, 1962, originally published in 1928), 146-47.

28. "Rapport sur le relevé du sol de la plaine de l'Artibonite," Bulletin du Service Technique de l'Agriculture et de l'Enseignement Professionnel, no. 5 (1926).

29. Marc Holly, Agriculture in Haiti, 27.

30. Moreau de St. Méry, Description topographique, physique, civile, politique et historique de la parte française de l'isle Saint-Dominque, vol. 2 (Paris: Chez Dupont, 1798), 116-27. 
1933, the nation's top expert on ethnography, Jean Price-Mars, visited the Ecole Centrale to promote the country's pastoral culture. "In an age when a crisis of barbarity pervades civilization in the modern world," he declared, "the Haitian spirit, in the peasantry, has conserved the purest primitive mettle" that would serve the nation well. ${ }^{31}$ In response to the Marine occupation, he implored the Ecole's students to embrace the peasant's "tales, legends, riddles, songs, [and] proverbs." Folklore, he argued, was "superb human material." 32 It would "mold" society's "collective mind" and promote "spiritual unity."

Marc Holly took this message plea to heart. Peasants "[are] extremely conservative," he lamented. Nevertheless, "they are neither as dull and stupid nor so intractable as we seem to believe."33 He thought about "the Russian peasants [who were once] held in similar contempt." They now sustained the great Soviet Union. Holly laughed. "History has shown that this view was fallacious!"34

31. Jean Price-Mars, "Géographie humaine et education technique: discours aux étudiants de Damien" (19 April 1922), Révue de la Société Haïtienne d'Histoire, de Géographie et de Géologie 9, no. 30 (Jul. 1938): 1-10. Price-Mars supported Melville Herskovits' claim in Life in a Haitian Valley (New York: Knopf, 1937), that Haiti's peasantry had preserved valuable knowledge inherited via the transatlantic slave trade.

32. Jean Price-Mars, So Spoke the Uncle (originally published in 1928), trans. Magdaline W. Shannon (Washington, D.C.: Three Continents Press, 1983), 17374. Also see Shannon's book, Jean Price-Mars, the Haitian Elite and the American Occupation, 1915-1935 (New York: St. Martin's Press, 1996).

33. Holly, Agriculture in Haiti, 52.

34. Ibid., 173. 
Price-Mars inspired a "Mouvement Indigèniste," in which painters and poets portrayed the countryside as a pastoral paradise. Artists such as Pétion Savain painted the peasant's everyday activities. They even invented a "primitive" style to celebrate what they perceived as provincial "simplicity." Meanwhile, poets like Emile Roumer, Phillipe Thoby-Marcelin, and Carl Brouard expressed what J. Michael Dash describes as a "utopian impulse."36 They envisioned the country as an open savannah with lush mango trees. ${ }^{37}$ In the monthly Revue Indigène, however, Brouard warned that "modernization" and "high mass-consumption" would destroy Haiti's serenity. "Paradise is lost like a wilting rose," he wrote. "It was a hut lurking deep in the mango grove, a flowering hibiscus and jasmine beside a flowing stream." 38

Brouard's companions-a lawyer named Lorimer Denis, and a young medical student named François Duvalier—took Indigènisme to new extremes. Denis and Duvalier wanted cultural "authenticity" in governance. They called themselves "griots." In Africa, Brouard explained, "the griots... are poets...

35. Eugenio Fernández Méndez, Le primitivisme haïtien (Port-au-Prince: Galerie G.S. Nader, 1972), 42-53. Also see Vodou Nation: Haitian Art Music and Cultural Nationalism (Chicago: University Press of Chicago, 2006), in which Michael Largey explains how Haitian composers incorporated what they interpreted as peasant culture into nationalist "art music."

36. J. Michael Dash, Literature and Ideology in Haiti, 1915-1961 (Totowa: Barnes and Noble Books, 1981), 66.

37. Ibid., 65-97.

38. Carl Brouard, "Paradis perdu," La Revue Indigène 1, no. 5 (Jan. 1928): 202. 
sorcerers," and Vodou priests, "ougans," who "speak to spirits through dreams."39 Like the Nazis, whom they initially admired, Denis and Duvalier believed psychology was genetic. Haiti's unique "ethnic mentality," they argued, necessitated "African" leadership. ${ }^{40}$ They blamed the country's poverty on "inauthentic" milat presidents and demanded black empowerment.

By contrast, the Parti Communiste Haïtien (PCH), led by the Indigèniste novelist, Jacques Roumain, wished to unite the peasantry and the urban working class. In his novel, Gouverneurs de la rosée (1944), Roumain introduced his own valley plan, "a dream" in which "water [was] running through... canals like a network of veins transporting life to the depths of [Haiti's] soil. ${ }^{41}$ Imagine, he wrote, "banana trees swaying under the silky caress of the wind, ears beaded with corn, plots of sweet potatoes strewn over the fields, all this burnt earth changed into verdant colors." Roumain believed that communism would make his

39. Carl Brouard, "Les Griots," Les Griots 1, no. 1 (Jul.-Sep. 1938): 17.

40. Lorimer Denis and François Duvalier, "Psychology ethnique et historique," Les Griots 1, no. 4 (Apr.-Jun. 1939): 473-502. Also see Smith, Red and Black in Haiti, 24-25; David Nicholls, "Biology and Politics in Haiti," Race 13, no. 2 (1971): 203-14.

41. Jacques Roumain, Masters of the Dew (originally published in 1944), trans. Langston Hughes and Mercer Cook (Oxford: Heinemann, 1978), 53, 75. Also see A Knot in the Thread: The Life and Work of Jacques Roumain (Washington, D.C.: Howard University Press, 1980), 118, in which Carolyn Fowler explains how Roumain's novels give "the impression that we are descending into the landscape, narrowing down our field of vision as we approach the ordinary people." 
vision a reality. ${ }^{42}$ "We'll rise up!" he shouted. "We'll call... a great big kombit [cooperative] of farmers, and we'll clear out poverty and plant a new life!"

While Roumain envisioned a pastoral utopia in Haiti, Benton MacKaye and the RPAA insisted that President Franklin Roosevelt tend to America's own "indigenous world:" the Tennessee Valley. ${ }^{43}$ The region was originally home to the Cherokee, the Creek, and the Shawnee, whom the US government removed in 1838. In the mid-to-late nineteenth century, Scottish, German, and Irish immigrants settled in the vacated territory. By 1930, the valley was home to 2.8 million people, including 300,000 African Americans, whose ancestors were enslaved to grow cotton in eastern Tennessee. ${ }^{44}$ The valley encapsulated America's complex history. "It was where Daniel Boone began," MacKaye noted. It was also "where the first march 'Westward Ho!' began—right there through the Watauga River, one of the upper branches of the Tennessee." ${ }^{\text {45 }}$ Outraged by industrialist Henry Ford's bid to industrialize Muscle Shoals in northern Alabama,

42. Hérold Toussaint, L'utopie révolutionnaire en Haïti: autour de Jacques Roumain (Port-au-Prince: Presses Nationales d'Haïti, 2012).

43. MacKaye, The New Exploration, 56-74.

44. North Callahan analyzes the Tennessee Valley's demographic history in TVA: Bridge Over Troubled Waters (New York: A.S. Barnes and Co., 1980), 1930.

45. Benton MacKaye, "Tennessee-Seed of a National Plan," Survey Graphic 22, no. 5 (May 1933): 251-54. 
MacKaye beseeched Roosevelt to implement a "regional plan" that would protect the valley and its unique heritage.$^{46}$

In 1933, Roosevelt entrusted the Tennessee Valley to a new authority: the TVA. Led by the Ohio conservationist, Arthur E. Morgan, the TVA's task was to implement "Regional Plan 1," a prototype that Roosevelt hoped to duplicate throughout the US in response to the Great Depression. ${ }^{47}$ It would build modern dams and excavate a canal system to irrigate the valley. At the same time, it would promote grassroots democracy and environmental conservation to negotiate a "middle landscape" between "modernization" and "the pastoral."

Toward this end, Roosevelt asked Morgan to live in the valley beside the people whose lives he would plan. Morgan would not have it any other way. He wholeheartedly believed that community organization was the "lifeblood of civilization" and the key to heaven on Earth. ${ }^{48}$ Mesmerized by Thomas More's Utopia (1516), Morgan insisted that it was based on Inca society and its "folkway of democratically-organized tribal communities," known as the "ayllu." ${ }^{, 49}$ Had the

46. Preston Hubbard describes Ford's proposal in Origins of the TVA: The Muscle Shoals Controversy, 1920-1932 (New York: W.W. Norton \& Company, 1961).

47. Franklin Roosevelt, Address to Congress (10 April 1933), in The Public Papers and Addresses of Franklin D. Roosevelt, ed. Samuel I. Rosenman, vol. 2 (New York: Random House, 1938), 122-29.

48. Arthur Morgan, The Small Community: Foundations of Community Life (New York: Harper \& Bros., 1942), 3.

49. Arthur E. Morgan, Nowhere was Somewhere: How History Makes Utopias and How Utopias Make History (Chapel Hill: University of North Carolina Press, 1946), 21, 149. In El jardín y el peregrino, 21-70, Beatriz Pastor Bodmer explains how the Conquest shaped many literary utopias in early modern times. As noted 
ayllu "been incorporated into the process of nation-building in Europe," he asked, "might not the history of the great continent have been finer and happier?"

As the TVA's chairman, Morgan took every opportunity to promote "democratically-organized" communities like those in Utopia. He sponsored cooperatives that shared tools and purchased electricity. He endorsed youth clubs, such as $4-\mathrm{H}$. He also built a model community named "Norris Village" in eastern Tennessee. Designed by Tracy Augur of the RPAA, the town had streets that were deliberately crooked and homes that resembled the valley's wooden cabins. ${ }^{50}$ "We also built a school house" and a "community church," Morgan boasted. $^{51}$

America's accomplishments impressed the young Marc Holly, who embraced Roosevelt's vision as his own. Holly liked to quote the president's speeches, especially that of 20 January 1937 . "We have set our feet upon the road of enduring progress," Roosevelt proclaimed, yet "I see one third of a nation

by George Logan in The Meaning of More's Utopia (Princeton: Princeton University Press, 1983), however, the book, Utopia, was probably based on late medieval humanism in Western Europe.

50. Tracy B. Augur, "The Planning of the Town of Norris" (Washington, D.C.: TVA, 1936). Also see Walter L. Creese, TVA's Public Planning: The Vision, the Reality (Knoxville: University of Tennessee Press, 1990), 245-57; Tim Culvahouse, The Tennessee Valley Authority: Design and Persuasion (Princeton: Princeton Architectural Press, 2007); Daniel Schaffer, "Garden Cities: The Tennessee Transplant," Town and Country Planning, no. 53 (1984): 316-18.

51. Arthur E. Morgan, The Making of the TVA (Buffalo: Prometheus, 1974), 89. 
ill-housed, ill-clad, ill-nourished!"52 Should "we pause now" and "call this the promised land?" he asked. "Have we found our happy valley?" Not yet. "We will carry on!"

The Arcadians Embark

Ironically, the journey to utopia commenced with SHADA, the government corporation instituted by President Lescot to grow cryptostegia. "The story of... SHADA," Holly explained, "is actually one of the saddest episodes in our agricultural history." Supervised by Holly's colleague, Maurice Dartigue, and a USG agronomist, Thomas A. Fennell, SHADA "inhumanely destroyed the peasants' food plantations and many of our fruit trees in order to devote excellent soils to... rustic plants." ${ }^{53}$ Holly was angry. SHADA, he exclaimed, was "stupid and insane," a "terrible mistake!" Thwarted by drought, Dartigue eventually came to the same conclusion. ${ }^{54}$ In 1944 , he beseeched the Institute of Inter-American

52. Franklin Roosevelt, Address (20 January 1937), in The Public Papers and Addresses of Franklin D. Roosevelt, vol. 6, 1-5.

53. Holly, Agriculture in Haiti, 181. Also see William Krehm's commentary on SHADA in Democracies and Tyrannies of the Caribbean in the 1940s (Toronto: Lugus Libros, 1999), 203-8.

54. As stated by Matthew Smith in Red and Black in Haiti, 45, "Dartigue... was alarmed at the measures taken [by SHADA], particularly in Jérémie, where nearly a million fruit-bearing trees had been cut down and the houses of peasants either invaded or razed." 
Affairs to invest 1 million US dollars in a "Food Supply Mission" that would help undo SHADA's mistakes. ${ }^{55}$

Inspired by Roosevelt's "Good Neighbor Policy," the IIAA leaped into action. ${ }^{56}$ Led by a USG technician, Marion N. Walker, the Institute distributed tools, seeds, and baby mango trees. It installed metal bins throughout the Artibonite Valley to preserve food (Fig. 5). It also built a new storage facility in the village of Coupon. ${ }^{57}$ Walker believed that Haiti would overcome the SHADA debacle. "That the problem is difficult is beside the point," he explained, "and the attitude of many.... that the situation is hopeless is equally so.. ${ }^{58}$ Hope springs eternal. "If the problem is difficult, it requires a better planned and executed attack on it. If the situation is hopeless it merely is so in relation to the methods used and the effort expended."

55. Accord signed by Maurice Dartigue and Hubert R. Bailey (1 October 1944), United States Operations Mission to Haiti, Unclassified Central Subject Files, 1948-1962 (OMUF), box 1: "Agreements: SCIPA, Administrative Services, 19441956," 4480782. Records of the United States Foreign Assistance Agencies, 1942-1963, Record Group 469, Entry No. 262, NACP.

56. As noted by Bryce Wood in The Making of the Good Neighbor Policy (New York: Columbia University Press, 1961), 7, the Good Neighbor Policy was based on "reciprocity." Roosevelt thought that "if the United States did certain things desired by Latin American states" then "these states would respond by doing other things desired by Washington."

57. IIAA, Food Supply Division, "A Summary Report: 1942-1947" (1947), 25, the United States Agency for International Development (USAID), Document Clearing House, Washington, D.C.

58. Ibid., 36. 


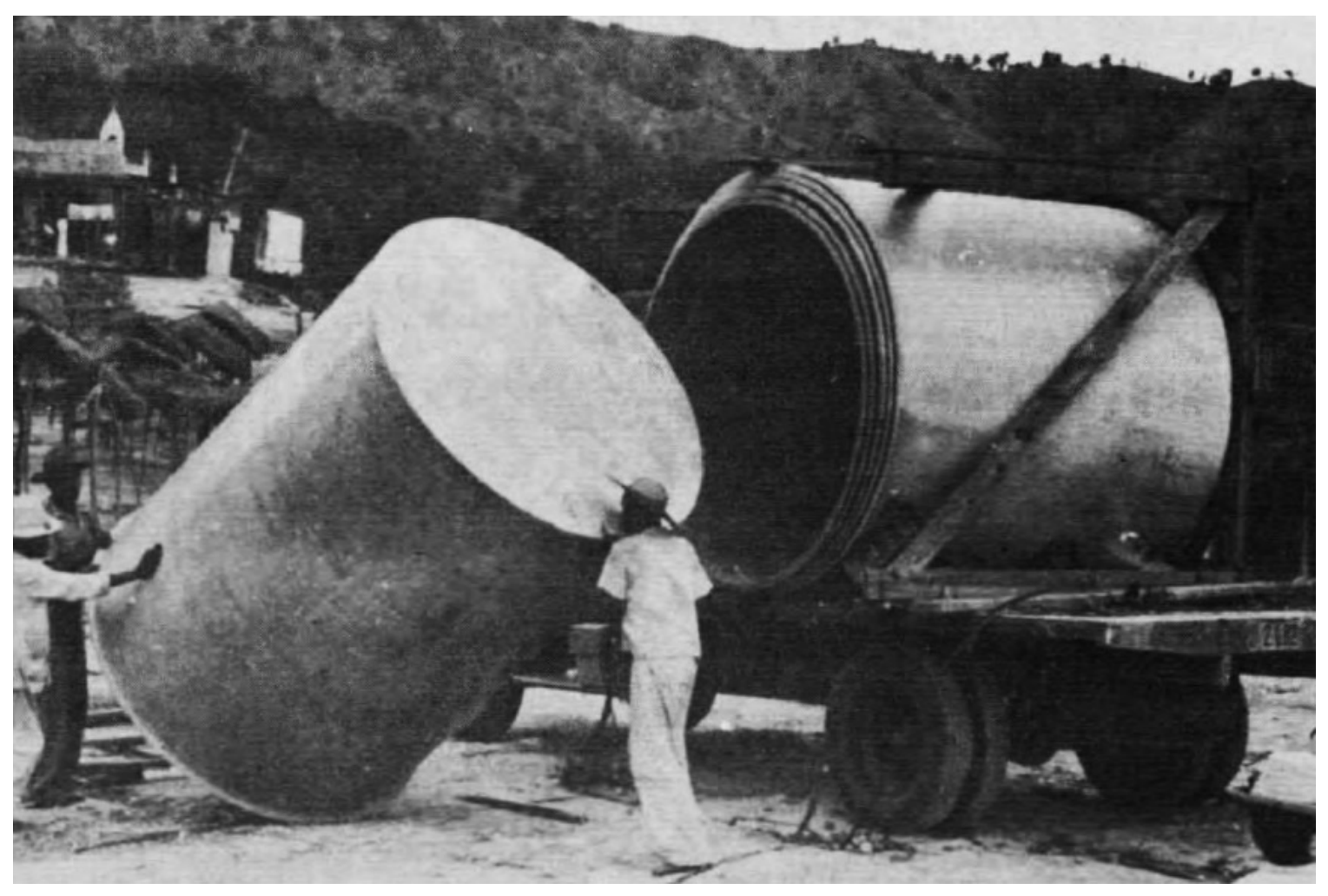

Fig. 5 The Institute of Inter-American Affairs in the Artibonite Valley. From: "Summary Report: 1942-1947" (1947) by the IIAA Food Supply Mission. Reproduced with permission.

As conditions in the valley improved, USG technicians began to survey land that was not yet cultivated. In early 1946, a specialist named Cecil Gingrass stumbled upon an "excellent" plot outside the town of L'Estère. Upon "talking to many peasants," he learned "that the soil was good, but... a crop [could] be realized" only "once in five years... because of insufficient moisture." 59 Apparently, the territory "had been under irrigation during the colonial days but had [since] been abandoned." Gingrass reported his discovery to Walker, and

59. Cecil Gingrass to George H. Hargreaves (1 March 1955), OMCF, box 8: "Individual Personnel Files," 3680145. 
they returned to the spot with a bulldozer and a pump, which they installed on a nearby tributary. They planted pit mil and soon had "an excellent crop."

President Lescot's successor, Dumarsais Estimé, was so impressed by the Food Supply Mission that he asked Walker to rehabilitate Bois Dehors in the northern Artibonite Valley. According to the IIAA, Bois Dehors was "a large area of barren wasteland." It was owned by the government, but it was "covered with mesquite and cactus. ${ }^{\text {"60 }}$ A USG technician named Bill Stowe mounted a pump beside the Estère waterway and excavated a canal system. "The ditch loss was terrific," he admitted. "Police had to be stationed along the canal to prevent the peasants from using all the water before it [arrived]." ${ }^{n 1}$ Once the land was irrigated, however, the IIAA divided it among the peasants, who planted rice and gave a third of the harvest to the Institute as payment. ${ }^{62}$

Camaraderie quickly developed between USG technicians and the peasantry. As a "machinery specialist" trained by the Indian Service in New Mexico, Stowe liked to show people how to use the Food Supply Mission's equipment. One day in Bois Dehors, he spotted a young man named Augustin Nathan, who was "trying to hold [a pony pull] in position to cut a drain in a very

60. SCIPA, "Eleven Years of Work in Haiti" (1955), 3-4, OMCF, box 9: "SCIPA Report, 1955," 3680154.

61. Bill Stowe, "Training Machine Operators" (April 1953), OMCF, box 11: "Part 4-14-B: Reports on Haiti, 1953," 3680201.

62. Vance Rodgers, "Agricultural Development Project No. 6" (1950), OMUF, box 1: "Agreements: SCIPA, Administrative Services, 1944-1956," 4480782. 
tight gumbo type of soil." ${ }^{63}$ Stowe asked Nathan to let him try. "By taking a light cut," he explained, "the little blade did a nice job." Nathan thanked him then pointed to the carryalls. Within a month, Nathan had acquired so many skills that he was able to negotiate a job with the IIAA. He made 90 US dollars a month, which he saved to buy a house.

By late 1947, Bois Dehors had metamorphosed into a tiny garden utopia. Gone was the mesquite and in its place were vegetables, such as peas and corn. The newly excavated canals also enabled the peasants to plant rice. Haitians praised the Food Supply Mission. "Anyone who has not seen the work being done... at Bois Dehors in the Artibonite cannot appreciate the importance of this program," one journalist reported. ${ }^{64}$ "It is amazing! ... Is it not gratifying to see corn and millet growing as mushrooms do in the trunk of a dead tree?"

Emboldened by the Food Supply Mission's accomplishments in Bois Dehors, Walker wanted to help the valley as whole. He uncovered the original study in which the Ecole Centrale proposed a canal system. "The main elements of these plans are sound today," he thought. ${ }^{65}$ "Modern pumping equipment... can be made to supply water so efficiently and economically that I do not believe

63. Stowe, "Training Machine Operators," 1-2.

64. "Ce que nous pensons à la Division 'Food Supply," Le Continental (8 October 1947): 1-2.

65. Marion Walker to Dumarsais Estimé (3 September 1947), United States Embassy in Port-au-Prince, Classified General Records, 1920-1964 (ECGR), box 23: "C8-11-861," 1719625. Records of the Foreign Service Posts of the Department of State, 1788-1991, Record Group 84, Entry No. UD2669, NACP. 
the need for a [large] dam... will ever develop." Walker presented his case to President Estimé. The Artibonite Valley, he explained, was "the greatest potential agricultural resource in the country." ${ }^{66} \mathrm{He}$ took out a map that divided the region into projects like the one in Bois Dehors. "The most likely prospect for attacking the problem is to organize the work into integrated units," he argued. ${ }^{67}$

Walker persuaded Estimé and the IIAA to institute a joint "Cooperative Service" that would expand the Food Supply Mission eastward, into a territory known as Villard. ${ }^{68}$ Led by a USG agronomist, Vance Rogers, the Service Coopératif Inter-Américain de Production Agricole (SCIPA) employed 30 Haitian specialists trained by the Ecole Centrale, now known as the Ecole Nationale d'Agriculture. ${ }^{69}$ In 1948, it summoned the community in Villard to come up with a plan. Subsequently, it installed a pump on the nearest tributary and mobilized the peasantry to excavate irrigation canals across $7.8 \mathrm{mi}^{2}$. Since most peasants were illiterate, Rogers placed "special emphasis on practical field

66. Ibid.

67. Map enclosed in Walker to Estimé (3 September 1947).

68. As explained by the IIAA in "The IIAA at Work" (1954), 2, "Servicio' is the [standard] name of the administrative devices, financed by contributions of the United States and the Latin American government, through which the Institute works with the other American republics in the execution of technical assistance for basic economic development programs." By 1952, the Institute had established Cooperative Services in 18 Latin American nations, three (Cuba, the Dominican Republic, and Haiti) in the Caribbean.

69. SCIPA, "Eleven Years of Work in Haiti," 1-12. Also see Ernst Bernardin's commentary on the Cooperative Service in L'espace rural haïtien, 177-79. 
demonstrations. ${ }^{70}$ Aided by SCIPA, the locals planted rice, and the harvest was impressive. "The future [potential of the Artibonite Valley]," Rogers reported, "may be gleaned from the Villard project."71

No one understood the potential of the "valley plan" better than Arthur Morgan's successor, David Lilienthal. As the Chairman of the TVA, Lilienthal implored President Harry Truman to endow valley plans modeled on his own Authority. The TVA, he explained, "speaks in a tongue that is universal" and "close to the lives of people: soil fertility, forests, electricity, phosphate, factories, minerals, [and] rivers. ${ }^{72}$ He envisioned a thousand TVAs and proudly supported the new Water Resources Authority in Puerto Rico, the Damodar Valley Corporation in India, and the Volta River Authority in the Gold Coast.

Naturally, Lilienthal praised Truman's plan to increase technical assistance to nations like Haiti. On 20 January 1949, Truman announced "Point IV," a "bold new program" to help "undeveloped areas" that might otherwise turn

70. Vance Rogers to Howard Travers (10 November 1951), OMCF, box 15 : "Part 4-9-A: General Personnel Files, 1951," 3680275.

71. Quoted in "Projet d'irrigation de Villard réalisé par le gouvernement," Le Nouvelliste (22 August 1949): 1, 4.

72. David E. Lilienthal, TVA: Democracy on the March (New York: Harper \& Row, 1953, originally published in 1944), 198. Also see "One Valley and a Thousand:" Dams, Nationalism, and Development (New York: Oxford University Press, 2007), in which Daniel Klingensmith documents Lilienthal's desire to create "1,000" new authorities. 
to the "false philosophy" of communism. ${ }^{73}$ In Latin America and the Caribbean, Point IV was administered by the IIAA, which was now able to expand its operation in the Artibonite Valley.

Following Truman's proclamation, USG technician Alan Laflin proposed a TVA in the Haitian countryside. The Artibonite Valley, he argued, would make an excellent laboratory to develop "a pilot for future Point IV operations in other parts of the world." ${ }^{\prime 74}$ According to Bill Stowe, Laflin met with President Estimé and "recommended... a TVA law" like the one passed in $1933 .{ }^{75}$

Estimé embraced the idea. ${ }^{76}$ In July 1949, he approached the ExportImport Bank to obtain a loan worth 4 million US dollars. ${ }^{77}$ Finally, on 5 September 1949, he approved a law that instituted the Organisation de Développement de la Vallée de l'Artibonite. The ODVA, like the TVA, would have an independent

73. Harry Truman, Address (20 January 1949), in The Public Papers of the Presidents of the United States: Harry S. Truman, vol. 5 (Washington, D.C.: Government Printing Office, 1961), 57.

74. Alan Laflin to William Brister (3 March 1950), OMCF, box 16: "Food Mission, 1950," 3680290.

75. Bill Stowe to Raymond C. Smith (29 November 1952), OMCF, box 12: "Artibonite Development, 1952," 3680215.

76. Anthony Georges-Pierre, Dumarsais Estimé: l'homme, l'œuvre et les idées (Port-au-Prince: Imp. S.A., 2012), 130-39. Also see Dumarsais Estimé: dialogue avec mes souvenirs (Port-au-Prince: Editions Mémoire, 2001), in which Lucienne $\mathrm{H}$. Estimé describes Dumarsais Estimé as a visionary president.

77. "Haïti aura 4.000.000 pour l'irrigation de l'Artibonite," Le Nouvelliste (7 July 1949): 1. 
"planning board" with "complete technical, administrative, and financial authority [to govern] all work... in the valley.."78

Tragically, Estimé did not get to see the organization that he signed into law. When his 4-year term expired in 1950, he was ousted by General Frank Lavaud and Colonel Paul Magloire. Nevertheless, the ODVA survived, and Magloire asked Marc Holly to head the planning board with Major Alcide Duviella. Holly was overjoyed. "We are now on the eve of the sesquicentennial of our independence," he declared. ${ }^{79}$ "I feel that the brilliant prospects opened up by the work of our illustrious heroes" in 1804 "will be achieved and completed!" Utopia was possible. "Haiti," he promised, "can look forward to a prosperous agriculture and a glorious future!"80

Without hesitation, the IIAA and SCIPA vowed to support Holly and Duviella. The IIAA immediately dispatched a burly technician named Norman Ward to the Ecole Nationale d'Agriculture in Damien, where he trained 50 Haitian specialists to lead the ODVA. He introduced them to modern machinery and taught them how to apply fertilizer (Fig. 6) ${ }^{81}$ Ward's mother, a "home

78. Law (5 September 1949), in Le bulletin des lois et actes: 1er Janvier à 31 décembre 1949, ed. Départment de la Justice (Port-au-Prince: Imp. de l'Etat, 1949), 524-28.

79. Holly, Agriculture in Haiti, 8.

80. Ibid., 309.

81. SCIPA, "The Damien Farm (1950), OMUF, box 2: "Agreements: SCIPA, Agricultural Demonstration, 1947-1953," 4480787. Also see Point IV, "Country Book: Haiti” (1950), 49-51, OMCF, box 16: "Point IV Program, 1950," 3680293. 


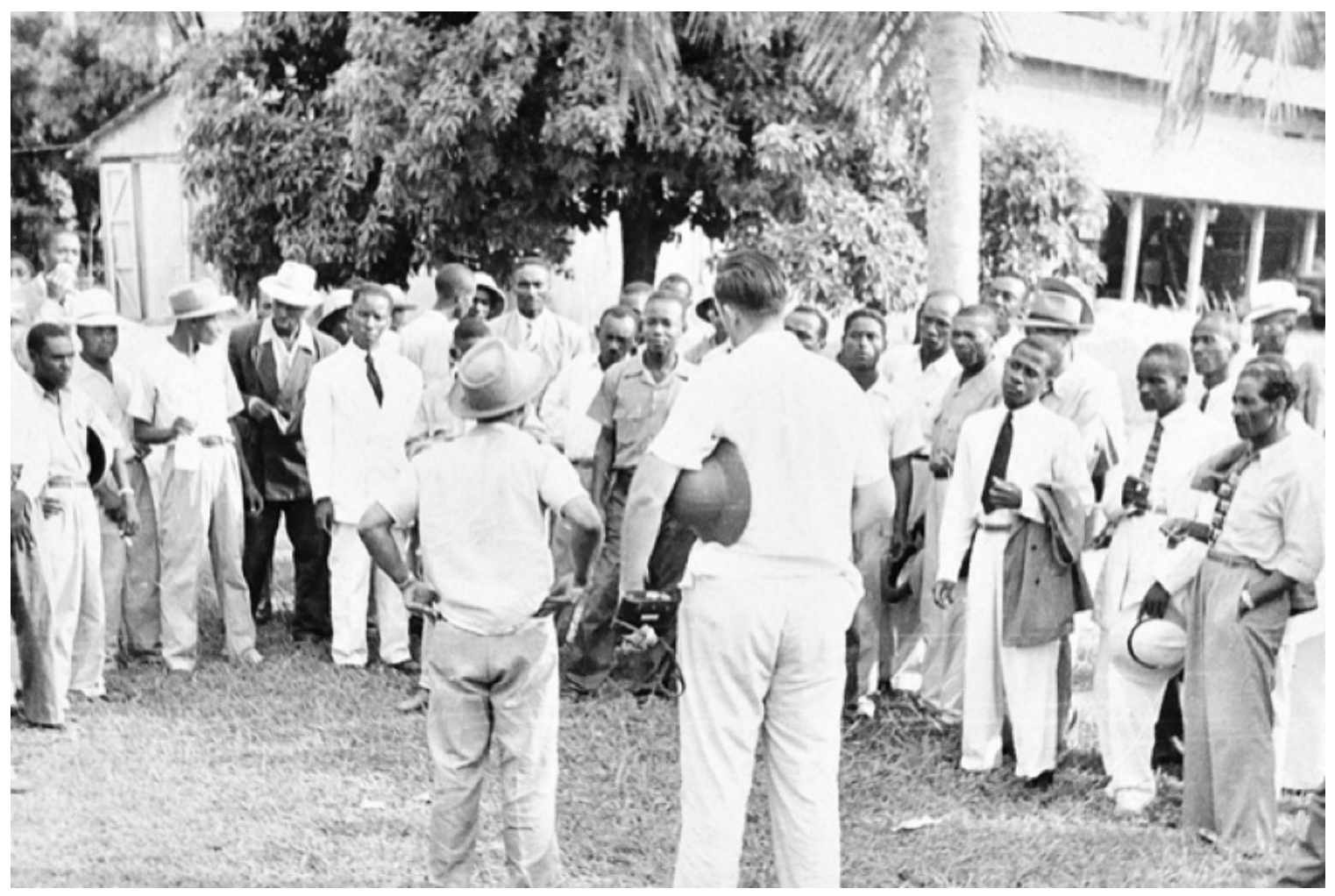

Fig. 6 Norman Ward (back to the camera, right), USG Technician with Haitian Specialists Outside the Ecole Nationale d'Agriculture. From: United States Operations Mission to Haiti, Unclassified Central Subject Files, 1948-1962, box 2: "Agreements: SCIPA, Agricultural Demonstration, 1947-1953," 4480787. Records of the United States Foreign Assistance Agencies, 1942-1963, Record Group 469, Entry No. 262, National Archives in College Park, Maryland.

demonstration" agent in Oklahoma, encouraged them to imagine Haiti's potential. "The dream of a [technician]," she told them, "passes beyond indifference and inertia. It includes green pastures, plentiful harvests, and flocks of sheep." ${ }^{82}$ The technician, she proclaimed, must "work tirelessly to make his dream a reality!"

82. Elizabeth Ward, "Rêves d'un traivailleur de l'extension," SCIPA: bulletin de nouvelles 1, no. 5 (Dec. 1949): 5, OMCF, box 16: "Food Mission, 1950," 3680290. 
Like most valley plans, the ODVA's began with a survey. "The complete view is important," Holly explained, because "without reliable statistics" technicians are "in the dark" and "[un]able to intelligently plan for the future." The Haitian government thus instituted the Bureau Cadastral de la Plaine de l'Artibonite and hired the Knappen-Tippetts-Abbett Engineering Company (KTA) to help conduct a survey. ${ }^{84}$ Founded in 1942 by Theodore T. Knappen, a West Point graduate and expert on hydrology, KTA handled surveys throughout the Americas and was widely respected. Paid 118,379 US dollars by Magloire, the company would take aerial photographs of the Artibonite Valley and use them to produce a 1:2,000 map.

In the meantime, Holly promoted community organization. Fortunately, the peasantry already practiced mutual aid. When "a peasant contemplates a strenuous [task]," Holly observed, "a kombit is organized," and "neighbors gather on his land to help." ${ }^{85} \mathrm{He}$ believed "this benevolent cooperation has behind it the force of pragmatic tradition" and "could provide the foundation for a larger association." To build upon this practice, the ODVA created a Service des Activités Sociales, which sponsored cooperatives, credit unions, and

83. Holly, Agriculture in Haiti, 167.

84. Contract (29 June 1950), in Le Moniteur (10 July 1950): 511-13.

85. Holly, Agriculture in Haiti, 176. Harold Courlander analyzes the kombit in The Drum and the Hoe: Life and Lore of the Haitian People (Berkeley: University of California Press, 1960). Also see James G. Leyburn, The Haitian People (New Haven: Yale University Press, 1941), 199-200; Alfred Métraux, "Cooperative Labor Groups in Haiti," in Peoples and Cultures of the Caribbean, ed. Michael M. Horowitz (Garden City: Natural History Press, 1971). 
conservation brigades throughout the Artibonite Valley ${ }^{86}$ Charles Antoine, the Chef des Organisations Sociales in Deseaux, a village 2.5 miles west of Dessalines, noted how the Service summoned the peasants to "have a vibrant discussion about the community's problems." ${ }^{\text {"87 }}$ According to Antoine, "everyone wanted to speak at the same time!" The assembly yielded a new Comité Local that mobilized the community to vanquish pesky rodents. ${ }^{88}$

The Haitian government supported Holly's emphasis on mutual aid. It introduced a new Conseil National de Coopération and an Institut Haïtien de Crédit Agricole et Industriel to provide money and expertise to peasant organizations ${ }^{89}$ The Ministère de l'Agriculture, meanwhile, adopted Europe's communitarian philosophy. Petitioned by Camille Lamothe, a Haitian attorney who advocated Owenism, the Ministère translated the "Rochdale Principles" into French and published them in its monthly bulletin. ${ }^{90}$ On 4 July, "International

86. By 1962, nearly one thousand peasants in the Artibonite Valley were participants in a cooperative. As stated by Marie-Thérèse Vallès in Les ideologies coopérativistes et leur applicabilité en Haïti (Paris: G.P. Maisonneuve et Larose, 1967), 30-31, "The ODVA.... contributed greatly to the formation of cooperatives [in Haiti]."

87. Charles Antoine, Quelques considerations sur le milieu rural: à deseaux, une experience de développement communautaire dans la Vallée de l'Artibonite (Port-au-Prince: Imp. N.A. Théodore, 1959), 41-43.

88. "L'invasion de l'Artibonite par les rats," La Phalange (4 February 1958): 1.

89. Mats Lundahl, "Some Reflections on the Cooperative Movement in Haiti," in Politics or Markets? Essays on Haitian Underdevelopment (New York: Routledge, 2002), 370-83.

90. "Les principes de Rochdale," Bulletin à l'usage des cercles d'études cooperatives 3, no. 1 (Jan. 1953): 1, OMCF, box 7: "SCIPA, 1951-1956, File 3," 4491646. Camille Lamothe published multiple volumes on communitarianism, 
Cooperation Day," the Ministère dispatched technicians to teach the peasantry about the Equitable Society. "Les coopérateurs haïtien," it proclaimed, "are happy to promote [the pioneers'] extraordinary principles!"91

While the Ministère publicized the Rochdale Principles, the ODVA organized youth clubs. Holly invited a West Indian agronomist, Wilfred Purdy, to introduce Haitian peasants to $4-\mathrm{H} .{ }^{92}$ Having led the $4-\mathrm{H}$ establishment in Jamaica, Purdy quickly organized a "mobile unit that traveled between villages. The unit, he explained, would try to "get boys and girls over the idea that menial work is below their dignity. ${ }^{93}$ It taught them about the environment and showed them movies about agriculture. Aided by schools throughout the valley, 4-H organized 60 youth clubs with 1,500 members (Fig. 7) ${ }^{94}$ Each club worked collectively on a common task, such as planting trees. According to one

such as Le mouvement coopératif et la question sociale (Port-au-Prince: Imp. de l'Etat, 1954), Cinq rapports sur le mouvement coopératif français et suisse (Portau-Prince: Imp. de l'Etat, 1954), and Contribution à la vulgarisation de la pensée coopérative (Port-au-Prince: Imp. de l'Etat, 1958). Also see Champagne Métellus, La doctrine coopérative (Port-au-Prince: N.p., 1948).

91. Ministère de l'Agriculture, Section des Coopératives, "Le manifeste des Pioneers de Rochdale" (4 July 1953), OMCF, box 7: "SCIPA, 1951-1956, File 3," 4491646.

92. Memo by John Burns (10 July 1951), OMCF, box 15: "Part 4-9-A: General Personnel Files, 1951," 3680275.

93. Paraphrased by Leland Allbaugh in his "Daily Report" on the Artibonite Valley (1 March 1952), OMCF, box 12: "Part 4-11-D-1: Planning Group Diary, $1952, " 3680217$.

94. Lee Winters to Harry Yoe (30 July 1958), OMUF, box 11: "Friends of Haiti, Inc.," 2843148. 


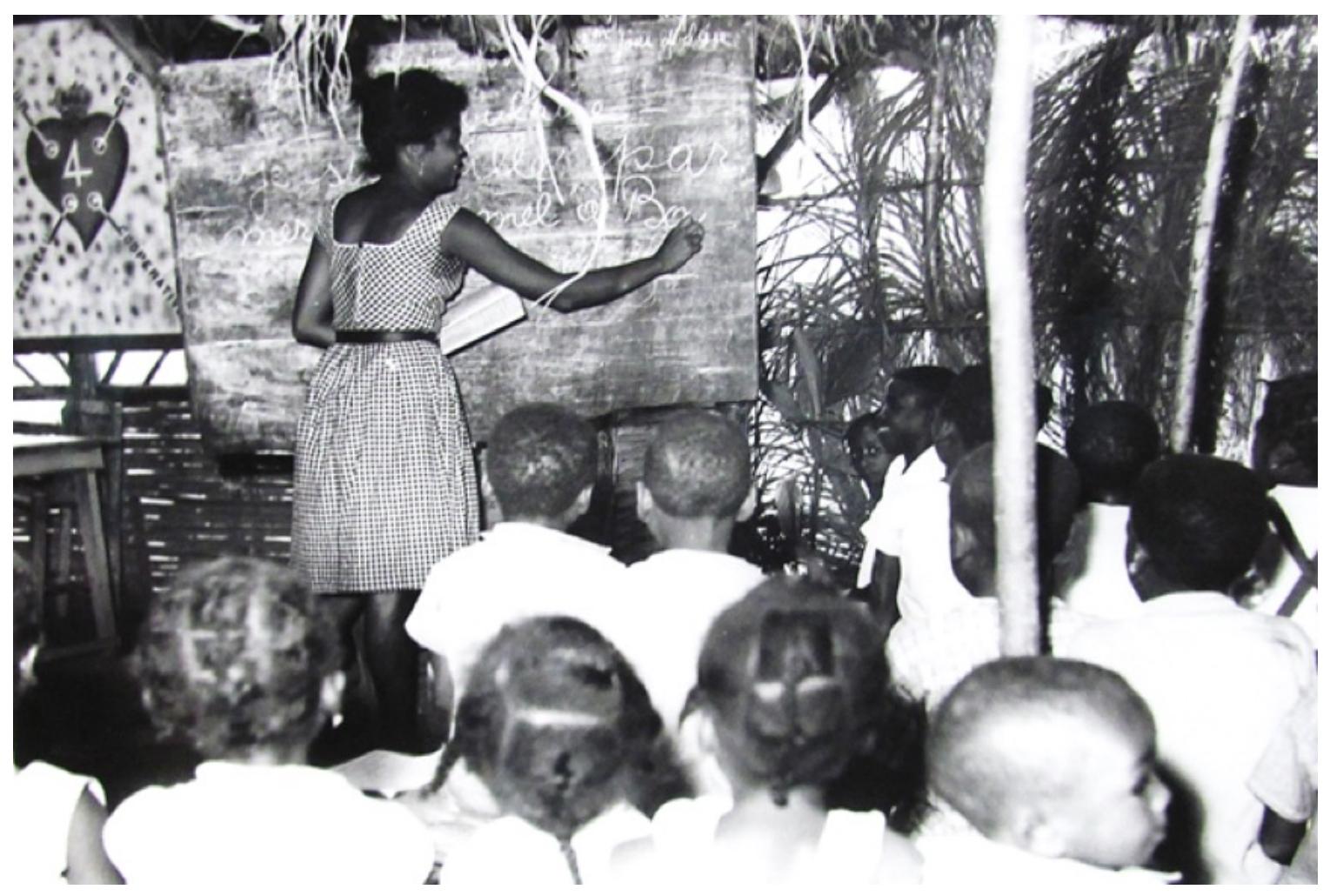

Fig. 7 4-H in the Artibonite Valley. From: Agency for International Development Mission to Haiti, Subject Files, 1957-1963, box 15: "SOC-1: Community Development," 5957725. Records of the Agency for International Development, 1948-2003, Record Group 286, Entry No. P-357, National Archives at College Park, Maryland.

eyewitness, 4-H cultivated "sharp minds, strong arms, healthy bodies, and honest hearts." 95

The IIAA insisted that USG technicians possess those same qualities.

Representative Raymond Smith recruited only "family men" to work in the Artibonite Valley. "I don't want an organization of college kids and old bachelors!"

95. Gérard Philippeaux, "Le SCIPA dans l'Artibonite," Le Nouvelliste (18 November 1950): 1, 4. 

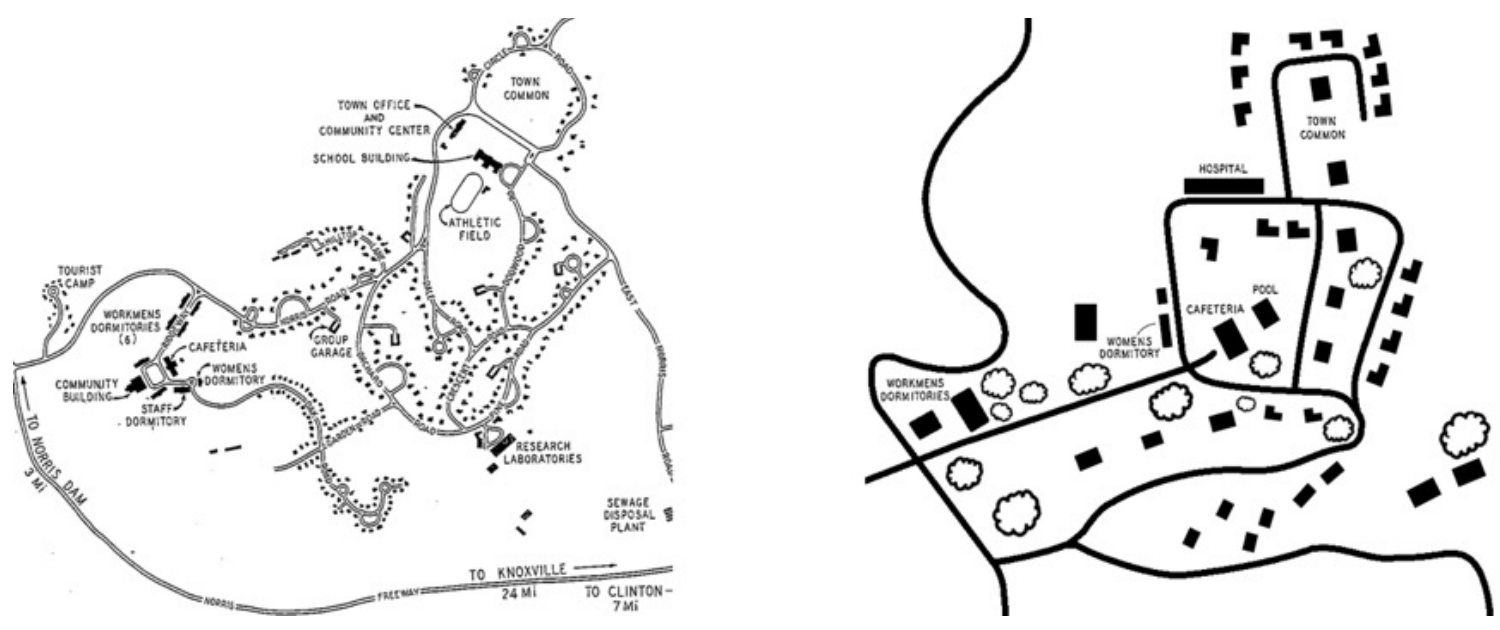

Fig. 8 Norris, Tennessee (left) and Deschapelle, Haiti (right). From: "The Norris Project" (1940) by the TVA and the United States Operations Mission to Haiti, Unclassified Central Subject Files, 1948-1962, box 20: "ODVA, 1959," 4481074. Records of the United States Foreign Assistance Agencies, 1942-1963, Record Group 469, Entry No. 262, National Archives in College Park, Maryland. The original map of Deschapelle is severely deteriorated. The one above was drawn by Adam M. Silvia.

he exclaimed. ${ }^{96}$ Technicians must "recognize that the real units... in development work are not acres or bushels of rice... but [Haitian] families."

Smith also believed that "technicians who are to work with the ODVA should live in the Artibonite Valley," so that "they can have a much better feel [for] the situation." Upon his request, the ODVA procured 16 homes in Deschapelle. Much like Norris Village in the Tennessee Valley, the ODVA's settlement included a mess hall, a community pool, a town common, and a women's dormitory that sheltered the wives and daughters of male technicians (Fig. 8). ${ }^{97}$

96. Raymond Smith to Rey Hill (11 December 1952), OMCF, box 12: "Artibonite Valley Agreements, 1952," 3680214.

97. Ray Lyman to Harry Yoe (17 July 1959), OMUF, box 20: "ODVA, 1959," 4481074. 
Haitians praised the ODVA's emphasis on community and conservation. Even the outspoken nationalist, Catts Pressoir, lauded its accomplishments. "More than a million fruit trees and other trees for reforestation have been planted!" he declared. "More than 100,000 agave plants [and] 603,000 pounds of improved seed have been distributed!"98 According to Pressoir, this would not have been possible had the ODVA not embraced "discussion" and "cooperation." Many people in the Artibonite Valley supported the ODVA. "By developing the land," a local priest explained, "not only [has the organization] increase[d] production," it has also encouraged those who "abandon[ed] their land" to "return" home ${ }^{99} \mathrm{He}$ implored the US to "sen[d] more engineers and agronom[ists....] You will not regret it!" he promised.

\section{Paradise Lost}

While the ODVA promoted community and conservation, private contractors like Knappen-Tippetts-Abbett (KTA) wanted the Haitian government to invest in science and technology. In late February 1950, KTA executive Theodore Knappen and his consultant, Raymond Hill, visited the Artibonite

98. Catts Pressoir, "Aspects psychologiques de l'application du Point Quatre," Révue de la Société Haïtienne d'Histoire, de Géographie et de Géologie 22, no. 82 (Jul. 1951): 44-67.

99. F. Solages to Raymond Smith (24 March 1953), OMCF, box 11: "Part 4-14B: Reports on Haiti, 1953," 3680201. 
Valley, where they met USG technician Alan Laflin. "I [previously] worked under Mr. Hill's supervision [in New Mexico]," Laflin explained, so "[l] was very glad to see him come!"100 They surveyed the valley by plane and had several lengthy conversations about the ODVA. "One session," Laflin claimed, "lasted until 11:30 at night!" Knappen and Hill insisted that a large dam was necessary to hold back the Artibonite River during the rainy season. Originally, the Food Supply Mission specialist, Marion Walker, told the Haitian government that such an investment was unwarranted, but Knappen thought heavy precipitation would overwhelm the new canal system.

Knappen circumvented the ODVA planning board and presented his case directly to Franck Lavaud and Paul Magloire. On 13 July 1950, he wrote them to say that "irrigation of the Artibonite Plain should not be initiated on an extensive scale without the installation of a dam and reservoir at [the] Péligre [canyon]."101 A dam, he conceded, would increase the total cost of the valley plan to 20 million US dollars, but "the Artibonite... will be protected against... inundations, and the value of annual agricultural production... will be increased by more than 3 million [US dollars]." Haiti could also use the dam to produce hydroelectricity. Knappen explained how "the income from the power system is estimated... at 350,000 [US

100. Alan Laflin to William Brister (25 February 1950), OMCF, box 16: "Food Mission, 1950," 3680290.

101. Theodore Knappen to Franck Lavaud, Antoine Levelt, and Paul Magloire (13 July 1950), OMCF, box 14: "Part 4-11-D: Artibonite Development, 1951," 3680253. 
dollars] per year and [would] increase in less than 20 years to about 2 million [US dollars] per year." This money, he believed, "will result... in a considerable increase in the standard of living."

Knappen's proposal exhilarated Magloire and Lavaud, who hoped to use the money generated by hydroelectrcity to improve education and public health. ${ }^{102}$ On 28 July 1950, they approved the plan and beseeched the ExportImport Bank to supply Haiti with an additional 12 million US dollars. They conceded that "the recommended project has increased greatly in size." Nevertheless, "a dam at [the] Péligre [canyon...] would make possible an important hydroelectric development." It was thus a "sound" investment. ${ }^{103}$ Worried that the Bank might reject the proposal, the military junta vowed "to demonstrate that... it can meet the requirements" to pay back the loan.

The Export-Import Bank was indeed hesitant to lend Haiti the extra money. It insisted that a new "Planning Group" survey the Artibonite Valley to assess the plan's viability. Led by the TVA economist, Edward Torbert, the Planning Group included nearly a dozen specialists with expertise in science and technology.$^{104}$ The Bank suspected that the ODVA chairman, Marc Holly, would oppose the new group because it violated his authority. The ODVA and the IIAA

102. "Le programme d'investissements de cinq ans," Le Nouvelliste (29 August 1951): 1 .

103. Gustave Laraque to Herbert Gaston (23 August 1950), OMCF, box 14: "Part 4-11-D: Artibonite Development, 1951," 3680253.

104. Planning Group, Personnel List (18 February 1952), OMCF, box 12: "Part 4-11-D-1: Planning Group Diary, 1952," 3680217. 
were thus invited to accompany Torbert on his journey. The IIAA was "a little frightened by the number of foreign technicians" in the Planning Group. ${ }^{105}$ Nevertheless, it appointed Norman Ward to the mission. The ODVA, however, deemed the "second authority" unnecessary. Torbert warned the Bank that the Planning Group's "inability to obtain ODVA-appointed Haitian counterparts” to help create what technically "would be an ODVA-Haitian plan... makes this [survey] extremely dubious." ${ }^{106}$

While Torbert and his companions knew a lot about technology, they were mostly ignorant about the peasantry. The Planning Group's record-keeper, TVA sociologist Leland Allbaugh, only knew what he had read in The White King of La Gonave (1931), a sensationalist tome by a Marine who participated in the US occupation. ${ }^{107}$ Curious about the peasants, Allbaugh spied on them as they went about daily life. "While enjoying some of the natives washing," he reported, "a group of three women... passed [by]." One woman "was... speaking rather loudly and unfriendly... warn[ing] us to get the hell out and not come back." ${ }^{108}$ Allbaugh could not understand Kreyòl, but he thought she said that "snakes would bite [us]

105. Vance Rogers to Rey M. Hill (21 November 1951), OMCF, box 14: "Part 411-D: Artibonite Development, 1951," 3680253.

106. Planning Group, Report (8 April 1952), 1, OMCF, box 12: "Part 4-11-D-1: Planning Group Diary, 1952," 3680217.

107. Planning Group, "Publications and Reports Brought to Haiti" (1952), OMCF, box 12: "Part 4-11-D-1: Planning Group Diary, 1952," 3680217.

108. Leland Allbaugh, "Daily Report on the Artibonite Valley" (9 March 1952), same location as the previous citation. 
and the negroes would beat the devil out of us!" He told his colleagues what happened, but they were still "not certain that [they would] need an anthropologist to help [them] out." 109

There was also tension between the Planning Group and Marc Holly. "All we wanted to know was how [Holly and Duviella] operated," Allbaugh claimed, but Holly "expressed [concern...] that the [Export-Import] Bank and [the] Americans might be trying to pry into Haitian affairs." ${ }^{110}$ Duviella begrudgingly presented Allbaugh with Holly's overall plan, whereupon Allbaugh "refused to read [it]." Allbaugh "wanted to [tell him that] 'we were not interested in mere day dreaming'” but held his tongue. "My wife's words... 'be careful of what you say,' came to mind." When the IIAA intervened to explain that Holly "would like to be in direct operational charge," Allbaugh laughed. ${ }^{111}$ Haitians "desire... complete freedom from any supervision by whites!" he exclaimed. ${ }^{112}$

Allbaugh portrayed Holly as grossly incompetent in his report to the Export-Import Bank. "Things are really... a mess!" he bellowed. "Last Friday... I was about to leave Bois Dehors [when I learned] that while [Holly] was in Portau-Prince last week... his [youth club] boys had [caught] another boy [stealing]

109. Vance Rogers to Rey M. Hill (13 March 1952), OMCF, box 12: "Part 4-11E: Artibonite Personnel, 1952," 3680216.

110. Allbaugh, "Daily Report on the Artibonite Valley" (8 March 1952).

111. Vance Rogers to John Burns (8 September 1951), OMCF, box 12: "Part 411-E: Artibonite Personnel, 1952," 3680216.

112. Allbaugh, "Daily Report on the Artibonite Valley" (7 April 1952). 
four or five onions." ${ }^{113}$ The club "took the [boy] out into the onion field and beat [him] up," and now "the loan shark in town has been able to get the boy to open suit against the [others] in court!" Allbaugh shook his head. "Onion stealing has become a whole community affair... with Marc Holly... taking out police to make arrests!" Allbaugh complained that Holly had "start[ed] too many things." As a result, the ODVA's youth clubs and cooperatives lacked supervision.

On 5 April 1952, the Planning Group went to IIAA's 10-year anniversary party at the American Club in Pétionville, where they debated Knappen's proposal to build the Péligre Dam. According to Allbaugh, the "ODVA board... came," but "Marc Holly... stayed in the background" while the Planning Group spoke to "the KTA people."114 Allbaugh noted how "the idea of "not needing a dam' ... came up." One technician thought the Péligre Dam was unnecessary, but his case provoked a "vigorous denial by KTA." Allbaugh could not "help but wonder whether... building ... a dam in a semi-barren, eroded... area ... is a wise investment." On the other hand, he "pointed out that certainly there would be... political pressure to go ahead with [the] construction [so that Magloire could] get [his] name on [it]."

Although some individuals in the Planning Group questioned the Péligre Dam's viability, the Group, as a whole, chose to support Knappen's proposal. In his report, Torbert told the Export-Import Bank that "the Artibonite Valley project,"

113. Allbaugh, "Daily Report on the Artibonite Valley" (2-3 April 1952).

114. Allbaugh, "Daily Report on the Artibonite Valley" (5-9 April 1952). 
as conceptualized by KTA, "will provid[e] a dependable supply of irrigation water" and prevent the "wild flooding of the Artibonite River." 115 As a result, "increased production... will provide increases in crop exports as well as... food for the republic." Most importantly, Torbert predicted that "project revenues... will exceed... operation costs during the latter part of the 10 -year development period in the aggregate amount of 575,000 [US dollars]."116 If the Péligre Dam stayed in operation for 50 years, "the total net revenue would be 12,696,000 [US dollars]."

Given Allbaugh's report, however, the Export-Import Bank would not trust Marc Holly with an additional 12 million US dollars. It capriciously slashed the proposal to 10 million and suggested that Magloire give up on hydroelectricity. It also insisted that a US "technical director" supervise Holly and Duviella until the Ioan was paid. ${ }^{117}$ Naturally, Holly was upset. On 17 November 1952, he met with IIAA technician Raymond Smith to talk about the ODVA bureaucracy. "Holly... drew a pen-and-ink organization chart," Smith attested. "In the top box," above

115. Edward Torbert et al., "Plan and Program for the Development of the Artibonite Valley" (1952), I-13, Ralph J. Bunche Federal Depository Library, Washington, D.C.

116. Ibid., 12.

117. Leland Allbaugh, Memo that summarizes a conversation at the ExportImport Bank (3 February 1952), OMCF, box 12: "Part 4-11-D-1: Planning Group Diary, 1952," 3680217. 
everything else, "he wrote 'ODVA representative." ${ }^{118}$ Holly eventually gave in to the Bank's demands, however, when it let the IIAA pick the technical director. ${ }^{119}$ Meanwhile, Knappen convinced the Export-Import Bank that KTA should design the Péligre Dam. A shrewd businessman, Knappen met with US diplomats to express "interest in the Point IV program and state that [he] hoped [KTA] would be able to fit into the plans of the US government" in the Artibonite Valley. ${ }^{120}$ Encouraged by the Bank to bid on the new contract, KTA submitted a low quote and won. In 1953, it employed Robert Burns, a graduate of the Massachusetts Institute of Technology (MIT), to design the dam.

Accompanied by the US Army Corps of Engineers, Burns journeyed to the Péligre canyon, where he analyzed rock samples to determine the best location for the structure. ${ }^{121} \mathrm{He}$ then produced a series of blueprints and asked the Civil and Sanitary Engineering Department at MIT to double check his calculations. ${ }^{122}$

118. Raymond Smith to Rey M. Hill (11 December 1952), OMCF, box 12: "Artibonite Valley Agreements, 1952," 3680214.

119. Memo by Rey M. Hill (23 December 1952), same location as the previous citation.

120. Paraphrased in a Memo (18 May 1950), OMCF, box 14: "Part 4-11-D: Artibonite Development, 1951," 3680253.

121. Memo (19 February 1952), OMCF, box 12: "Artibonite Development, $1952, " 3680215$.

122. KTA, "General Plan for the Péligre Dam" (31 July 1953), Leonard A. Lovell Papers (LALP), American Heritage Center, University of Wyoming, Laramie, Wyoming. Also see Rafael Antonio Morales, "Design of a Buttress Dam Section at the Péligre Canyon" (B.S. Thesis: MIT, 1955); Ralph M. Parsons Laboratory for Water Resources, "Hydraulic Model Performance of Spillway and Outlet 
Upon review, the ODVA warned KTA that its design threatened to destroy the nearby village of Petit-Fond. The company, however, wanted the inhabitants to pick up and move. One community, it thought, was a small price to pay to "modernize" the country. ${ }^{123}$

Unlike the TVA, which built its own dams, the Haitian government had to rely on a private contractor, Brown \& Root, which had built the Mansfield Dam outside Austin, Texas in the late 1930s. Represented by six US engineers, Brown \& Root hired a dozen Haitian specialists and nearly 100 laborers, who established a camp in the Péligre canyon. ${ }^{124}$ Unconcerned with the ODVA's conservation policy, it used bulldozers and cranes to excavate 500,000 cubic meters of rock and earth. ${ }^{125}$ It then mixed 600,000 tons of concrete and unloaded nearly 1,500 tons of steel.

Marc Holly loathed Brown \& Root. He was especially angry when the company exceeded its budget by 10 million US dollars and demanded 2.6 million

Works of the Péligre Dam" (1955), MIT, Institute Archives, Cambridge, Massachusetts.

123. Army Corps technician Richard L. Meehan portrayed the Haitian countryside as primitive in Getting Sued and Other Tales of the Engineering Life (Cambridge: MIT Press, 1981), 195.

124. Brown \& Root, "L'usine pour la construction du barrage de Péligre" (1955), OMCF, box 9: "Artibonite Development, 1954," 3680158.

125. KTA, "Expenditure Report" (30 September 1954), table 3, "Estimates by Brown \& Root," same location as the previous citation. 
to complete the Péligre Dam. ${ }^{126}$ "Brown \& Root has no right to meddle in the financial affairs of [the] ODVA!" Holly exclaimed. "[Haiti] does not possess inexhaustible caverns [of wealth] permitting [it] to draw at any time any quantity of money!" ${ }^{127}$ Pummeled by Hurricane Hazel in October 1954, the country was already in dire straits without Brown \& Root's exorbitant request. ${ }^{128}$ In 1955, the Export-Import Bank lent Haiti an extra 6.8 million US dollars to pay Brown \& Root, but Holly thought the company should have been held responsible. ${ }^{129}$ As a symbolic gesture, he declared two USG technicians, Alan Laflin and Cecil Gingrass, "persona non grata."130

Even though Holly had no say in the construction of the Péligre Dam, he would have to deal with the consequences. Completed in 1956, the structure created a reservoir that swallowed nearly 500 homes. Holly evacuated the inhabitants in advance but also wanted to compensate them with land. A cash settlement was inadequate, he argued, because "the money would soon be

126. I.N. Towne to Alcide Duviella (24 November 1954), OMCF, box 9: "Artibonite Development, 1954," 3680158.

127. Alcide Duviella, Marc Holly, and Antoine Soray to KTA (21 June 1954), same location as the previous citation.

128. Frank Kimball et al., Memo on the Haitian economy (18 February 1954), OMCF, box 9: "Artibonite Development, 1954," 3680158.

129. Roy Davis, Memo (25 March 1955), OMCF, box 7: "Artibonite Development, 1955," 3680129.

130. William Dolan to Robert Couse (12 January 1955), OMCF, box 8: "Individual Personnel Files," 3680145. Also see George Hargreaves to Raymond Smith (2 March 1955), same collection, box 9: "Various Memos, 103.9," 3680155. 
spent," and "these people would [still] be without homes." ${ }^{131}$ Magloire agreed. He promised them state-owned land, but there was not enough to go around. ${ }^{132}$ As a result, the displaced villagers settled haphazardly beside the reservoir. The government took nearly two years to institute a commission to compensate the dispossessed, and only those with a title were eligible. ${ }^{133}$

Magloire, having broken one too many promises, abruptly resigned on 12 December 1956, throwing the ODVA into disarray. Preoccupied in Port-auPrince, the interim president, Frank Sylvain, gave little thought to the Artibonite Valley. As a result, "project operations are at a virtual standstill," one witness bewailed. ${ }^{134}$ Even though the organization's canal system was only 40 percent complete, the Export-Import Bank would not lend Haiti any additional money, so both KTA and Brown \& Root picked up and went home. ${ }^{135}$

131. Paraphrased in the Memo by Frank Kimball et al. (18 February 1954).

132. Law (3 November 1954), in Le Moniteur (15 November 1954): 823-24. Also see Milton Barall, Memo (21 December 1954), OMCF, box 9: "Artibonite Development, 1954," 3680158.

133. "Rapport de la commission d'enquête sur les dépossessions des paysans de la Vallée de l'Artibonite" (Port-au-Prince: Imp. de l'Etat, 1958), New York Public Library, Stephen A. Schwarzman Library, Rare Book Division, New York, New York.

134. Anonymous Airgram (9 October 1957), OMCF, box 6: "Reprogramming Consideration, October 1957," 3680098.

135. Robert Middlemas to Rollin Atwood (26 October 1956), OMCF, box 6 : "Artibonite Valley Inspection," 3680107. Also see Robert Peterson to John Hoover (10 June 1957), same collection, box 5: "Agriculture and Natural Resources, 1957," 3680080. 
In desperation, Holly and Duviella turned to the US, but it was unresponsive. President Truman's successor, Dwight Eisenhower, had already replaced the IIAA with the International Cooperation Administration (ICA), whose representative, John Hoover, believed the Artibonite Valley was "poorly planned." Hoover insisted that "not one dollar of [ICA/USOM] funds... be contributed to the ODVA... until the present, slipshod, unrealistic operations and management are replaced." ${ }^{136}$ Like "darkest Africa," Haiti "is not really... civilized," he sneered. It "is not [even] capable of managing its own affairs." ${ }^{137}$ Disheartened, Holly and Duviella quit the ODVA in early 1957.

\section{Duvalier's Dystopia}

A ship without a captain, the ODVA survived on its own momentum until 22 September 1957, when François Duvalier seized the presidency with the military's support. Everyone hoped Duvalier would put the country back on track, and initially it seemed he would. First, he instituted a "Grand Conseil Technique" to create an economic recovery plan. ${ }^{138} \mathrm{He}$ then appointed three individuals to

136. John Hoover to Grover C. Kincaid (21 March 1957), OMCF, box 4: "ODVA, 1958," 3680056.

137. John Hoover, Memo (30 October 1956), OMCF, box 4: "Programs and Submissions, 1958," 3680061. Also see Memo (25 January 1957), same collection, box 5: “Embassy, 1957," 3680085.

138. "Le plan de deux ans du Grand Conseil Technique," Le Nouvelliste (7 January 1959): 1 . 
lead the ODVA: a major named Oswald Hyppolite, a bureaucrat named Gérard Philippeaux, and Garvey Laurent, a local technician who had studied agronomy at the University of California, Berkeley. President Eisenhower was greatly impressed. He recalled the mingy John Hoover and appointed a young West Virginian, Harry Yoe, as the new director of the ICA and USOM in Haiti. ${ }^{139}$

Determined to save the ODVA, Yoe immediately touched base with Laurent. "Please accept my congratulations on your new position!" he exclaimed. ${ }^{140}$ "Be assured that all of your many friends in [the ICA are] stand[ing] by ready to help you in any way possible!" Yoe persuaded the ICA's new Development Loan Fund (DLF) to lend Haiti an additional 4.3 million US dollars to complete the ODVA ${ }^{141} \mathrm{He}$ also dispatched his best technician, Norman Ward, to the Artibonite Valley. "I know how you have devoted yourself to this cause and to... true... cooperation between the Haitian and... American people," Hyppolite wrote Yoe. "For my own part... I shall be forever grateful!"142

139. Caspar D. Green to Henry J. Randal (1 July 1958) and (13 August 1958), Agency for International Development Mission to Haiti, Subject Files, 1957-1963 (AMSF), box 2: "Correspondence, Harlan A. Harrison, 1958-1960," 5957726. Records of the Agency for International Development, 1948-2003, Record Group 286, Entry No. P-357, NACP.

140. Harry Yoe to Garvey Laurent (17 November 1958), OMCF, box 1: "Director's Files," 3680013.

141. Harry Yoe, Memo (18 June 1959), OMCF, box 1: "Development Loan Funds, 1959," 3680015.

142. Oswald Hyppolite to Harry Yoe (no date), OMCF, box 1: "Director's Files," 3680013. 
Hyppolite's optimism quickly dissolved in July 1958, however, when three exiled Army men and five US mercenaries (two Miami Dade-County sheriffs) invaded Haiti to overthrow the new government. Although the intruders were killed, Duvalier became increasingly paranoid and tyrannical. He implored the Assemblée Nationale to lend him "emergency powers." He then purged the Haitian military and created his own militia, the Tonton Macoutes. Led by the vicious Clément Barbot, the Macoutes included nearly 25,000 men and women. $^{143}$

Unbeknown to Yoe, Duvalier mistrusted the US and told Laurent to subordinate the ICA and USOM. In late March 1959, Yoe "heard that the Director of the ODVA," Laurent, "was very dissatisfied with the conditions of the [DLF loan]." Apparently, he "interpreted [it] as placing him and the Haitian government in the position of minor infants who might be given money but... must be carefully supervised." ${ }^{144}$ When they met in person, Laurent "who is normally extremely friendly" conveyed "this attitude with [such] frankness" that Yoe was in shock. "He exhibited a deep suspicion of the... ICA" and "stubbornly insisted on points [that] were patently absurd!" Yoe exclaimed. ${ }^{145}$

Overcome with remorse, Laurent eventually confessed that Duvalier wanted him to bully the ICA. He then informed Norman Ward of the president's

143. Diederich and Burt, Papa Doc, 123-47.

144. Harry Yoe, Memo (18 April 1959), OMCF, box 2: "Application Approval, $1959, " 3680026$.

145. Harry Yoe, Memo (14 July 1959), OMCF, box 2: “ODVA, 1959," 3680025. 
plan to promote a mutiny in the Artibonite Valley. According to Laurent, Gérard Philippeaux was Duvalier's "political whip" and planned to "systematic[ally] raid... key positions within the ODVA." ${ }^{146}$ Ward "checked and cross checked" Laurent's testimony with Haitians loyal to the ICA and USOM. "I believe [it] to be true," he told Yoe. "The president [will soon] make a formal request to Garvey Laurent for the removal of the executive officer, [the] chief accountant, [the] chief of [personnel, the] chief agriculturalist, and the research agriculturist in order to place... in these positions... loyal supporters of the Duvalier regime."

A showdown was imminent. On 30 September 1959, Ward summoned his trusted ally, the Chef Macoute, Clément Barbot, who was once a technician, employed by the IIAA. Escorted by Barbot, Ward took Laurent back into the valley, where they fired everyone involved in the conspiracy. ${ }^{147}$ Philippeaux protested to Yoe that "Ward had exceeded his authority" and was "trying to take over full management of the project." ${ }^{\text {148 }}$ When Yoe threatened to suspend the DLF loan, Philippeaux was indignant. Haitians "need the help of the DLF," he lamented, "but we do not intend to relinquish sovereignty over our government!" According to Ward, Philippeaux shouted that "people in valley were going to rise

146. Norman Ward to Harry Hoe (29 December 1959), same location as the previous citation.

147. Harry Yoe, Memo (10 October 1959), OMCF, box 2: "Application Approval, 1959," 3680026.

148. Quoted by Nolle Smith in a Memo (3 March 1960), OMCF, box 1: "Artibonite, Confidential," 3680006. 
up" and "cut Laurent's body up into pieces and deliver it to Port-au-Prince" unless the ICA backed down. ${ }^{149}$

Philippeaux continued to threaten the ICA with violence. On 3 March 1960, he "arrived in [the Artibonite Valley] with... five carloads of men," said Ward. "[They were] well armed with carbines, pistols, [and] tommy guns." 150 Philippeaux insisted that Duvalier had the authority to appoint new personnel to the ODVA, but Ward stated that it was "not in the best interest of the project." When Ward declared that "[ICA] certification of DLF funds would not be made," Philippeaux and his posse went away. That night, however, "four [gun]shots were fired... over Laurent's house." The next morning, Yoe took away the DLF money and gave up on the Artibonite Valley. ${ }^{151}$

While the ICA's withdrawal bankrupted the ODVA, it enabled Duvalier to seize the Péligre Dam and use it to legitimize his own tyranny. His vision was to build a Centrale Hydro-Electrique and "modernize" the country. In March 1961, he turned to the former chairmen of the TVA, David Lilienthal and Gordon Clapp, who now operated a private consultancy named the Development \& Resources Corporation. When Clapp arrived in Port-au-Prince, Duvalier's aide, Clovis Désinor, presented him with a memo that explained how "every program [and]

149. Norman Ward to Harry Yoe (15 March 1960), same location as the previous citation.

150. Ibid.

151. "Artibonite Dismissal Strife: Cessation of Funds to ODVA," Haiti Sun (20 March 1960): 1, 16. Also see Bernard Diederich's testimony in Island of Fear: Hispaniola, 1960 (Port-au-Prince: Henri Deschamps, 2010), 91-99. 
development plan [was] based on energy." ${ }^{152}$ Hydroelectricity was the "sine qua non of industrialization." It would "increase the country's revenues and employ excess [population]." ${ }^{153}$

Clapp sympathized with the Haitian people. He thus traveled to the Péligre Dam to evaluate its potential. On his way through the Artibonite Valley, he saw "villages" and "small farms." ${ }^{154}$ He noted how "very, very hard" the peasants had "to scratch" to buy "the cottons and colorful garb they wear." Finally, he reached the Péligre canyon and witnessed Brown \& Root's creation. The Péligre Dam, he proclaimed, without question, "constitute[s] the largest single low-cost power source available in [Haiti]" ${ }^{155}$ Surprised to see it "already there but idle," he believed it "represents an almost irrevocable turning point in the economic development of the country." Clapp promised the Haitian government that he would design the Centrale Hydro-Electrique and submit the blueprints to the Inter-American Development Bank (IDB).

Duvalier had one last obstacle: the Compagnie d'Eclairage Electrique. Owned by Philips, the company possessed an exclusive concession to produce electricity in Haiti until 1971. Determined to build his own Centrale Hydro-

152. Memo on "le rôle de la cie d'eclairage électrique" (30 March 1961), Development \& Resources Corporation Records (DRCR), box 188: "Haiti, 19591965." Mudd Manuscript Library, Princeton University, Princeton, New Jersey.

153. Memo on "une politique nationale de l'électrification" (29 March 1961), same location as the previous citation.

154. Gordon Clapp, Journal (30 August 1960), DRCR, box 188: "Haiti, 1959."

155. Ibid. 
Electrique, however, Duvalier pressured the firm to give it up. He refused to pay the government's electric bill and let people tap into the electrical grid to steal nearly 1 million kilowatts per month. ${ }^{156}$ The company's manager, Everett Shrewsbury, wanted to intervene but thought his workers "would be [... physically] beaten by the Tonton Macoutes. ${ }^{157}$ Finally, in 1961, when the Haitian government encouraged Shrewsbury's employees to go on strike, the company surrendered its concession and abandoned the country. ${ }^{158}$

The IDB noted how Duvalier had become increasingly authoritarian. On 14 July 1960, the Garde Présidentielle imprisoned Clément Barbot, whose loyalty was suspect. Duvalier then dismantled the Assemblée Nationale and converted Fort Dimanche into a political prison. ${ }^{159}$ In early 1962, the Bank warned David Lilienthal that Duvalier was "pretty awful" and "not someone to be trusted." ${ }^{\text {"160 }}$ The

156. Memos on the Compagnie d'Eclairage Electrique (2 December 1959, 6 January 1960), ECGR, box 46: "350: Memo of Conversation, Jul. to Dec. 1959," 1719625. Also see Ernest Bonhomme to François Duvalier (10 March 1960), Duvalier Correspondence Collection (DCCO), box 1: "Bonhomme to Duvalier." New York Public Library, Schomburg Center for Research in Black Culture, Manuscripts, Archives, and Rare Books Division, New York, New York.

157. Robert Newbegin and Everett Shrewsbury, Memo (16 February 1961), ECGR, box 47: “350: Memo of Conversation, Jan. to Jun. 1961,” 1719625.

158. Philip P. Williams and Everett Shrewsbury, Memo (5 October 1960), ECGR, box 46: "350: Memo of Conversation, Jul. to Dec. 1960," 1719625.

159. As explained by Bernard Diederich in Fort Dimanche (Port-au-Prince: N.p., 2014), the prison claimed nearly 3,000 lives between 1957 and 1985. Also see Patrick Lemoine, Fort-Dimanche, Fort la Mort (Montreal: CIDIHCA, 1996); Gérard Pierre, The Last Captured (New York: Vantage, 2000).

160. Entry (18 June 1962), in The Journals of David E. Lilienthal, vol. 5 (New York: Harper \& Row, 1971), 310. 
last straw came on 26 April 1963, when a gunman loyal to Barbot tried to kidnap Duvalier's children, Jean-Claude and Simone, outside the Nouveau Collège Bird in Port-au-Prince. Macoutes chased the man into the Dominican embassy and nearly provoked a joint invasion by the United States and the Dominican Republic. ${ }^{161}$ In response, the IDB gave up on the Centrale Hydro-Electrique. Coincidentally, Duvalier's last ally, Gordon Clapp, died of a heart attack later that month.

Abandoned by the ICA and the IDB, Duvalier resorted to extraordinary measures to build the Centrale Hydro-Electrique. He introduced an "economic liberation" lottery to raise money and insisted that businesses buy "economic liberation" bonds. ${ }^{162} \mathrm{He}$ then organized a special commission to persuade an Italian company, Gruppo Industrie Electro Mechaniche Per Impianti All' Estero, to implement the plan by Gordon Clapp. ${ }^{163}$ Between 1968 and 1970, the company installed three vertical turbines beside the Péligre Dam. It also set up a 34-mile transmission line, connecting the new Centrale Hydro-Electrique to Port-auPrince. ${ }^{164}$

161. Carlo A. Désinor, Il était un fois: Duvalier, Bosch et Kennedy, 1963 (Portau-Prince: Imp. II, 1989), 129-60.

162. Memo (6 October 1962), ECGR, box 50: "501: Economic Aid to Haiti," 1719625. Also see "Certificat de libération économique" (no date), DCCO, box 1: "Money Notes."

163. Robert Newbegin, Memo (14 July 1963), ECGR, box 50: "501: Economic Aid to Haiti," 1719625.

164. CONADEP, "Aspects techniques de l'amenagement de la Centrale HydroElectrique François Duvalier," Avancement des Travaux, no. 33 (Mar. 1969): 6-8, 
On 21 April 1971, Duvalier died of heart disease. His dystopian vision, however, lived on through the Centrale Hydro-Electrique François Duvalier de Péligre. The Centrale symbolized Duvalier's unbreakable will to "modernize" the nation and helped legitimize his son's claim to the presidency. On 22 July 1971 , the young Président à Vie, Jean-Claude Duvalier, traveled to the Péligre canyon to celebrate the plant's completion. "As I touch the button that will send electricity to the capital," he proclaimed, "I feel my father's hand on mine.... He lives eternally!"165 A poet, Max Piquion, then delivered his "Dialogue de Péligre," which hailed the advent of "modernity." ${ }^{166}$ Clovis Désinor, meanwhile, distributed commemorative medallions that showed François Duvalier's face on the front and bolts of electricity on the back (Fig. 9).

The Duvaliers had triumphed, but Haiti, as a nation, had ultimately lost. The Centrale Hydro-Electrique betrayed the utopian impulse that originally inspired the ODVA. It also cost 17 million US dollars that should have been invested in the organization's canal system. As a result, Marc Holly's achievements in the Artibonite Valley crumbled. According to one eyewitness, "many responsible Haitian technicians... fled to escape persecution by zealous

Elmer Holmes Bobst Library, Special Collections and Archives, New York University, New York, New York.

165. Jean-Claude Duvalier, Address (22 July 1971), in 90 jours de gouvernement: de la prestation de serment à l'apotheose de Péligre (Port-auPrince: Presses Nationales d'Haïti, 1971), 77.

166. Max Piquion, "Le dialogue de Péligre," in Pérennité: pour inaugurer à Centrale Hydro-Electrique François Duvalier de Péligre (Port-au-Prince: N.p., 1971), 35-39. 

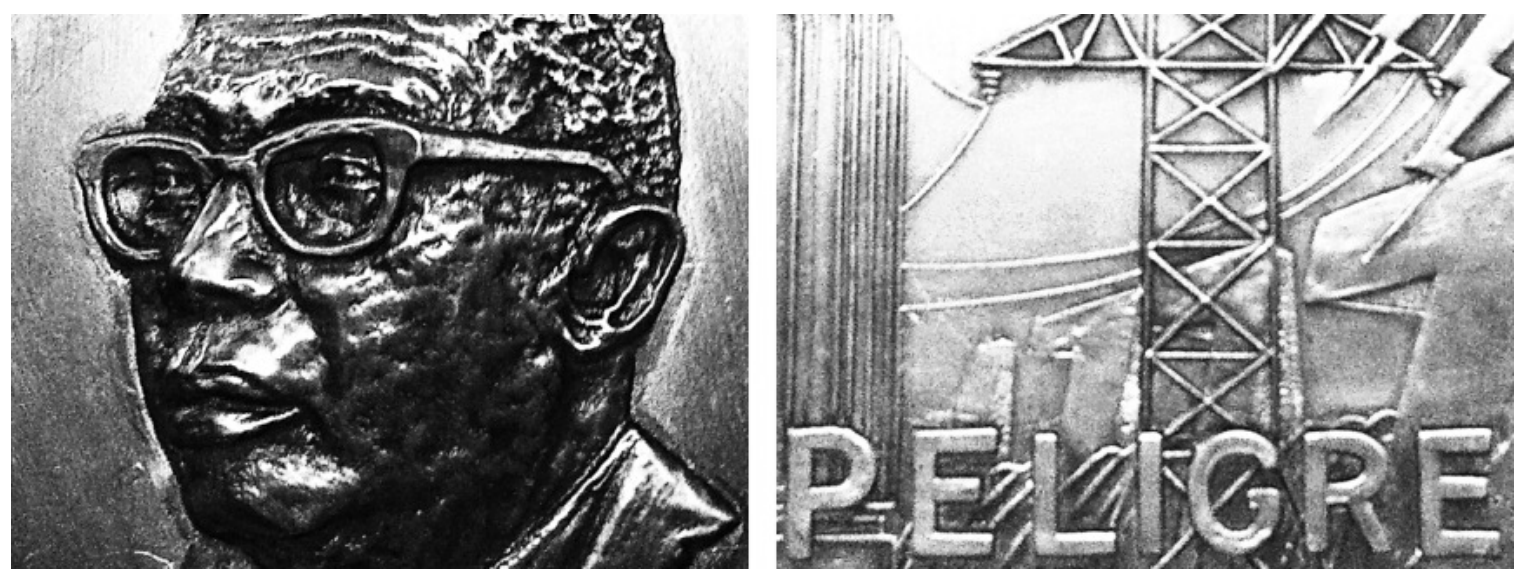

Fig. 9 Centrale Hydro-Electrique François Duvalier de Péligre, Commemorative Medallion Minted in 1970. From: Bernard Diederich, Private Collection. Reproduced with permission.

government agents," who "systematically hunted experts who were less devoted to the consolidation of dictatorial power." ${ }^{167}$ A second witness observed how the government "abandoned [the peasants] to themselves." Those "who had no direct involvement in the [ODVA] and no instruction" shoveled dirt back into the canals "to reclaim the land." ${ }^{\text {"68 }}$ Sadly, Holly's vision was dead and buried in the soil from which it came.

167. Sebastien Hilaire, Le prix d'une agriculture minière (Port-au-Prince: Imp. Natal, 1995), 244-45.

168. Robert Israël Bury, "Organisation de Développement de la Vallée de l'Artibonite," in Développement rural en Haïti et dans la Caraïbe, ed. J.B. Roumain (Port-au-Prince: Imp. Rodriguez, 1980), 80-86. 


\section{FAMILY PLANNING IN FOND PARISIEN}

In the early 1960s, nearly every day, a nurse would march into the maternity ward at the Hôpital Général in Port-au-Prince to distribute a small note to the patients. "Maman," it read, "compliments pour votre bébé."1 The note, however, was less congratulatory than depreciative. Children are expensive, it warned. "You must feed them, clothe them, and send them to school." Hardly subtle, the message was not to have any more children. Mothers were advised to visit the family planning clinic inside the hospital, where they would meet a Haitian physician named Ary Bordes.

Like many technicians, Bordes was alarmed by population growth.

Between 1950 and 1960, Haiti's population had increased 20 percent. Bordes believed that Haiti would become an overpopulated dystopia unless someone intervened to stem the "human tide." ${ }^{2}$ He thus instituted the Centre d'Hygiène Familiale (CHF) in 1965. Backed by neo-Malthusian missionaries from the United

1. Note (no date), Unitarian Universalist Service Committee Records (USCR), serial no. 16026, box 13: "Haiti, Monthly Reports." Andover-Harvard Theological Library, Harvard University, Cambridge, Massachusetts.

2. Many literary dystopias, such as Make Room! Make Room! (New York: Orb, 2008 , originally published in 1966) by Harry Harrison, portray overpopulation. As explained by William B. Schwartz in Life without Disease: The Pursuit of Medical Utopia (Berkeley: University of California Press, 1998), 153-54, they normally "depict a macabre program of mass extermination as a way to deal with the overpopulation caused by medical progress." 
States, the CHF included a dispensary in Port-au-Prince and a clinic in the backwater town of Fond Parisien. The clinic was a prototype, a "laboratory" in which Bordes and his supporters developed new methods to contain population growth.

Motivated by neo-Malthusian anxiety, the CHF was nonetheless utopian. Bordes envisioned Fond Parisien as a heavenly paradise, governed by his own technical knowledge. His plan was to "liberate" and "empower" local mothers with contraception and Western medicine. He would help them prevail as "nation bearers," so they could take on new tasks outside the home as "nation builders." The missionaries were equally utopian. As Unitarian Universalists, they were religiously opposed to political and economic imperialism. They wanted Bordes to "unburden" Haitian women, so they could pioneer a "third way" to prosperityindependent of US imperialism and Soviet ideology.

The utopian impulse shared by Bordes and the missionaries complicates how we normally talk about population control in the mid-to-late twentieth century. In his book, Fatal Misconception: The Struggle to Control World Population (2008), Matthew Connelly explains how "the onset of the Cold War" and "the communist victory in China" made "defusing... population [growth an] overriding priority," as China's "human wave" strategy in the Korean War "revived visions of a racial apocalypse." ${ }^{3}$ The Population Council in New York, the

3. Matthew Connelly, Fatal Misconception: The Struggle to Control World Population (Cambridge: Belknap Press, 2008), 161. Also see "The Cold War in the Longue Durée: Global Migration, Public Health, and Population Control," in The Cambridge History of the Cold War, vol. 3, 467, in which Connelly 
Population Crisis Committee in Washington, D.C., and the United States Agency for International Development (USAID), which succeeded the ICA in 1961, promoted contraception to lighten the load on the capitalist world-economy. They believed that population control would increase wealth per-capita; end poverty; contain communist revolutions; and maintain US hegemony. ${ }^{4}$ The Unitarian Universalists, however, criticized the end goal. Hence, they empowered a Haitian technician, Ary Bordes, and voluntarily served as his intermediaries with contraceptive suppliers.

The missionaries' interest in a "third way" contradicts the historiography on ideology and religion in the Cold War era. In his book, Religion and American Foreign Policy, 1945-1960: The Soul of Containment (2010), William Inboden portrays religion as an anticommunist ideology. Throughout the US, he argues,

conceptualizes the Cold War as "a struggle to control populations, and not just territory, with the two superpowers adopting contrasting but comparable approaches to policing their biopolitical boundaries."

4. Peter J. Donaldson, Nature Against Us: The United States and the World Population Crisis, 1965-1980 (Chapel Hill: University of North Carolina Press, 1990). The historiography on population in the Cold War era also includes Nick Cullather, The Hungry World: America's Cold War Battle Against Poverty in Asia (Cambridge: Harvard University Press, 2013); Ronald Walter Greene, Malthusian Worlds: US Leadership and the Governing of the Population Crisis (Boulder: Westview Press, 1999); John H. Perkins, Geopolitics and the Green Revolution: Wheat, Genes, and the Cold War (New York: Oxford University Press, 1997); Phyllis Tilson Piotrow, World Population Crisis: The United States Response (New York: Praeger, 1973); James Reed, "Public Policy on Human Reproduction and the Historian," Journal of Social History 18, no. 3 (Spring 1985): 383-98;

Simon Szreter, "The Idea of Demographic Transition and the Study of Fertility: A Critical Intellectual History," Population and Development Review 19, no. 4 (Dec. 1993): 659-701. 
people "believed that their nation had a divine calling to oppose the Soviet Union" and "reshape the world according to the divine design." Likewise, Jonathan P. Herzog says that "theologians who studied communism... began to conclude that it stood for... the destruction of organized religion," because "communism held that people could perfect themselves through an inevitable historical process." The missionaries in Fond Parisien, however, were ambivalent toward the Soviet Union. Inspired by Unitarian Universalism's emphasis on liberty, they openly chastised the US when it violated Haiti's national sovereignty.

Ary Bordes and the Unitarian Universalists were independent thinkers. Disturbed by the Vietnam War and the assassination of Martin Luther King, Jr., they questioned the US government's moral authority. They disavowed US hegemony and exhibited humanist values that we normally associate with the Peace Corps. ${ }^{7}$ As noted by Steve Stern, "the Vietnam experience, a

5. William Inboden, Religion and American Foreign Policy, 1945-1960: The Soul of Containment (New York: Cambridge University Press, 2010), 4.

6. Jonathan P. Herzog, The Spiritual-Industrial Complex: America's Religious Battle Against Communism in the Early Cold War (New York: Oxford University Press, 2011), 5-6. Also see Ira Chernus, Nuclear Madness: Religion and the Psychology of the Nuclear Age (Albany: State University of New York Press, 1991); Donald Crosby, God, Church, and Flag: Senator Joseph R. McCarthy and the Catholic Church, 1950-1957 (Chapel Hill: University of North Carolina Press, 1978); T. Jeremy Gunn, Spiritual Weapons: The Cold War and the Forging of an American National Religion (Westport: Praeger, 2009); Dianne Kirby, Religion and the Cold War (New York: Palgrave Macmillan, 2013); Philip Muehlenbeck, Religion and the Cold War: A Global Perspective (Nashville: Vanderbilt University Press, 2012).

7. As noted by Elizabeth Cobbs Hoffman in All You Need Is Love: The Peace Corps and the Spirit of the 1960s (Cambridge: Harvard University Press, 2000), 8-9, "the Peace Corps [was] perhaps the quintessential social reform institution of 
demonstration of amazing technical capacity to project power abroad... in conjunction with complex domestic social dynamics, including those associated with the Civil Rights Movement... ended up fracturing the political values and certainty of will that emanated from the [US]." It unlocked "a political space for... skepticism that defended the unfettering of political processes and revolutions in the Third World." 8

The CHF, however, was not wholly transcendent. It upheld a neoMalthusian perspective on population that was "inherently misanthropic." As explained by Ernst Bloch, the economist, "[Thomas] Malthus, decided in his Essay on the Principle of Population (1798) that the reason for misery lies in the 'natural' contradiction between man's boundless striving for propagation and the limited increase in means of nourishment." ${ }^{\text {9 }} \mathrm{He}$ believed "it is proletarian lechery,

[the 1960s]." It "incorporate[d] volunteering into [US] foreign policy in an attempt to demonstrate [an] alternative to power politics."

8. Steve Stern, "The Decentered Center and the Expansionist Periphery: The Paradoxes of the Foreign-Local Encounter," in Close Encounters of Empire, 60. The historiography on skepticism in the Cold War era includes Michael Bess, Realism, Utopia, and the Mushroom Cloud (Chicago: University of Chicago Press, 1993); Jamie Cohen-Cole, The Open Mind: Cold War Politics and the Sciences of Human Nature (Chicago: University of Chicago Press, 2014); Tobin Siebers, Cold War Criticism and the Politics of Skepticism (New York: Oxford University Press, 1993); Alan Brinkley, "The Illusion of Unity in Cold War Culture," in Rethinking Cold War Culture, eds. Peter Kuznick and James Gilbert (Washington, D.C.: Smithsonian, 2010), 61-73.

9. Bloch, The Principle of Hope, vol. 2, 465-69. Bloch's take on Malthus is based heavily on Outline of a Critique of Political Economy (1844) and The Condition of the Working Class in England in 1844 (1845), in The Collected Works of Karl Marx and Frederic Engels, vols. 3 and 4. 
not capital[ism], which produces social misery." He thus overlooked how the modern world-system trapped people in poverty.

Bordes and the missionaries condemned the world-system. Like Malthus, however, they approached poverty and population growth as "cultural problems" that could be solved by Western medicine. ${ }^{10}$ Trained by Johns Hopkins University, Bordes possessed technical knowledge about the human body and maintained that it was indisputable truth. ${ }^{11} \mathrm{He}$ wished to promote national independence yet exhibited what Johanne Tremblay describes as "l'ethique néocoloniale." ${ }^{12}$ Unlike the technicians in the Artibonite Valley, who mixed techne with mētis, Bordes belittled the peasantry's African and Creole practices; butted heads with community leaders; and tried to indoctrinate children into neoMalthusianism. ${ }^{13}$

10. As noted by W.F. Bynum in The Western Medical Tradition: $1800-2000$ (New York: Cambridge University Press, 2006), 3, what constitutes "Western medicine" has constantly evolved. In the past 200 years, however, "there has been a constant stream of investigators who have, by examining the smallest structures possible, tried to find out how living things work and how disturbances of their normal function come about."

11. In both The Birth of the Clinic: An Archaeology of Medical Perception (originally published in 1963), trans. A.M. Sheridan Smith (New York: Vintage, 1994), and The History of Sexuality, 3 vols. (originally published between 1976 and 1984), trans. Robert Hurley (New York: Vintage, 2012), Michel Foucault analyzes how technical knowledge about the body originally emerged.

12. Johanne Tremblay, Mères, pouvoir et santé en Haïti (Paris: Karthala, 1995), 181-210.

13. Ironically, Bordes participated in the same medical imperialism described by Laura Briggs in Reproducing Empire: Race, Sex, Science, and US Imperialism in Puerto Rico (Berkeley: University of California Press, 2002) and 
Bordes also told mothers how to cook and clean. He wanted to empower them but instead validated the assumption that work in the home was "travay fanm," i.e. "women's work," not men's. He thrust back upon women's shoulders every responsibility in the home, upholding the "repressive apparatus" that "controls and silences" Haitian women. ${ }^{14}$ In addition, Bordes planned to burden mothers with new tasks outside the home, when they already toiled in the marketplace as merchants and tended livestock when men were absent. As explained by Mireille Neptune Anglade, absenteeism was common, because some husbands had more than one spouse and many crossed into the Dominican Republic to seek employment. ${ }^{15}$ Bordes hoped to liberate mothers but only worsened the unequal division of labor between men and women that pervades both Haitian history and Latin American history as a whole. ${ }^{16}$

Marcos Cueto in Cold War, Deadly Fevers: Malaria Eradication in Mexico, 19551975 (Baltimore: Johns Hopkins University Press, 2007).

14. M. Catherine Maternowska outlines this apparatus in Reproducing Inequalities: Poverty and the Politics of Population in Haiti (New Brunswick: Rutgers University Press, 2006), 131.

15. Mireille Neptune Anglade analyzes the division of labor in L'autre moitié du développement à propos du travail des femmes en Haïti (Montreal: CIDIHCA, 1986), 55-126. Also see Marlène Thélusma Rémy, Contribution de la femme haïtienne à la construction et à la survie de son pays (Paris: L'Harmattan, 2008); Grace Louise Sanders, "La Voix des Femmes: Haitian Women's Rights, National Politics, and Black Activism in Port-au-Prince and Montréal, 1934-1986" (Ph.D. Dissertation: University of Michigan, Ann Arbor, 2013).

16. Elizabeth Dore and Maxine Molyneux document this inequality in Hidden Histories of Gender and the State in Latin America (Durham: Duke University Press, 2000). Also see Susan K. Besse, Restructuring Patriarchy: The Modernization of Gender Inequality in Brazil, 1914-1940 (Chapel Hill: University of North Carolina Press, 1996); Eileen J. Suárez Findlay, Imposing Decency: The 
The Human Tide

In 1947, Haiti was visited by Margaret Sanger, a top advocate of contraception in the US. Sanger taught First Lady Lucienne Estimé about the virtues of birth control, but Estimé was only mildly interested. ${ }^{17}$ Sanger thus moved on to India, where she helped coordinate the Third International Conference on Planned Parenthood in $1952 .{ }^{18}$ The summit yielded a new organization, the International Planned Parenthood Federation (IPPF), which opened a lonely clinic in Haiti. ${ }^{19}$

Contraception was not a priority until the late 1950s and early 1960s, when eugenicists and ecologists noted a sharp spike in human population. ${ }^{20}$

Politics of Sexuality and Race in Puerto Rico, 1870-1920 (Durham: Duke University Press, 1999); K. Lynn Stoner, From the House to the Streets: The Cuban Woman's Movement for Legal Reform, 1898-1940 (Durham: Duke University Press, 1991).

17. "Dancing with a Voodoo Priest: Sanger, Art, and Birth Control in Haiti," The Margaret Sanger Papers Project Newsletter 18, no. 50 (Winter 2008).

18. In his book, A History of the Birth Control Movement in America (Santa Barbara: Praeger, 2011), Peter C. Engelman describes Sanger's role in organizing the first birth-control clinic in the US in 1916, the American Birth Control League in 1921, the Planned Parenthood Federation of America in 1942, and the International Planned Parenthood Federation in 1952.

19. Matthew Connelly examines IPPF in "Seeing Beyond the State: The Population Control Movement and the Problem of Sovereignty," Past \& Present 195 (Nov. 2006): 197-233.

20. Pierre Desrochers and Christine Hoffbauer, "The Post War Intellectual Roots of the Population Bomb," Electronic Journal of Sustainable Development 1, no. 3 (Summer 2009): 37-61. Also see Matthew Connelly, "To Inherit the 
Widespread panic culminated in The Population Bomb, a sensationalist tome by Stanford University professor Paul Ehrlich and his wife, Anne. The book insisted that population control was the only way to prevent an apocalyptic war over the planet's natural resources. "People in positions of power have either ignored the problem or have recommended solutions that are inadequate," the Ehrlichs bewailed. ${ }^{21}$ "Some Latin American politicians have accused the United States of attempting to pressure them into population control programs. If only it were true!"22

Unbeknown to the Ehrlichs, social scientists in Latin America were equally disturbed by population growth. In Haiti, the government's Bureau de Recensement, led by demographer Jacques Vilgrain, predicted that the country's population would double to 6.8 million by $1995 .{ }^{23}$ At the UN Centro Latinoamericano de Demografía in Chili, meanwhile, a second Haitian expert,

Earth: Imagining World Population, from the Yellow Peril to the Population Bomb," Journal of Global History 1, no. 3 (Nov. 2006): 299-319.

21. Paul Ehrlich and Anne Ehrlich, The Population Bomb (New York: Ballantine Books, 1968), 78, 90.

22. In the book, Medicine and Public Health in Latin America (New York: Cambridge University Press, 2014), 193-94, Marcos Cueto and Steven Palmer explain how "Latin American public health and political leaders responded slowly to these attacks and eventually joined the population control programs" advocated by the US.

23. Bureau de Recensement, Recensement général de la République d'Haïti: population, habitation, agriculture en 1950 (Port-au-Prince: Imp. de l'Etat, 1950). 
Jacques Saint Surin, warned that Vilgrain's calculations were too low. Surin believed Haiti's population would double by $1979 .^{24}$

In retrospect, Vilgrain's estimates were too low and Surin's too high.

Nevertheless, they made many people nervous. "Jacques St. Surin... estimates that our population will increase to $7,341,033$ by 1980 ," the physician, Ary Bordes, exclaimed. ${ }^{25}$ Likewise, the Unitarian Universalist Service Committee, a philanthropic organization created by members of the Unitarian Universalist Church, expressed shock when it visited Haiti in 1965. "This country is crowded!" it bemoaned. "It is the old story-too many people for the land to feed." 26

Bordes sounded the alarm. He commissioned a Haitian artist, Préfète Duffaut, to illustrate overpopulation for the Haitian people. ${ }^{27}$ Duffaut painted an imaginary landscape in which Haitians occupied every square inch and excess population spilled off the sides of cliffs. ${ }^{28}$ Entitled "La marée humaine," i.e. "The Human Tide," the painting was so morbid that the UN protested when Bordes

24. Jacques Saint Surin, Indices démographiques et perspectives de la population d'Haïti de 1950 à 1980 (Port-au-Prince: Imp. de l'Etat, 1962), 21.

25. Ary Bordes, Presentation in Chemin des Dalles (1968), 2, USCR, serial no. 16026, box 15: "Haiti, Centre d'Hygiène Familiale."

26. UUSC, "Hold That Line" (no date), USCR, serial no. 16026, box 15: "Haiti."

27. Ary Bordes to John McAward (6 February 1974), USCR, serial no. 16093, box 1: "Bordes, Correspondence, 1974-1976."

28. "La marée humaine," lithograph, USCR, serial no. 16093, box 3: "Haitian Painting," 
requested that it display the canvas at the upcoming World Population Conference in Romania.

Worried that a "human tide" would outstrip the capitalist world-economy, social scientists and philanthropists mobilized the US to control population growth.$^{29}$ In 1952, the zealous Cold Warrior, John D. Rockefeller III, created the Population Council, a private organization headquartered in New York. Led by Frank Notestein, an expert on demography at Princeton University, the Council worked tirelessly to change the widely-held opinion that contraception was immoral. ${ }^{30}$ Tycoon Hugh Moore and Army General William Draper, however, thought Notestein was too timid. In 1965, they co-founded the Population Crisis Committee, which lobbied Congress to promote contraception overseas. ${ }^{31}$

Pressed by the Population Council and the Crisis Committee, the US government joined the population control movement in 1965 with bellicose determination. In his State of the Union address, President Lyndon B. Johnson promised to "seek new ways to use our knowledge to help deal with the

29. John Sharpless, "Population Science, Private Foundations, and Development Aid: The Transformation of Demographic Knowledge in the United States, 1945-1965," in International Development and the Social Sciences, eds. Frederick Cooper and Randall Packard (Berkeley: University of California Press, 1997), 176-202. Also see Susan Greenhalgh, "The Social Construction of Population Science: An Intellectual, Institutional and Political History of Twentieth-Century Demography," Comparative Studies in Society and History 38, no. 1 (Jan. 1966): 22-66; Paul Demeny, "Social Science and Population Policy," Population and Development Review 14, no. 3 (Sep. 1988): 451-79.

30. Connelly, Fatal Misconception, 159-60.

31. Ibid., 231. 
explosion in world population." ${ }^{32}$ In response, Congress allocated 2.1 million US dollars to USAID, which instituted a new Office of Population, led by Reimert Ravenholt. A proponent of modernization theory, Ravenholt embraced medical technology, especially birth control. Encouraged by the eugenicist Association for Voluntary Sterilization, he invested heavily in IPPF and advocated surgical contraception as a way to protect "US commercial interests around the world."33

Mothers to the Nation

While USAID bombarded the world with contraceptives, the Haitian physician, Ary Bordes, came up with his own plan to contain population growth and took it to the Unitarian Universalist Service Committee. In 1965, the Committee's spokeswoman, Alice Sheridan, visited Haiti to participate in a symposium on nutrition. There she met François Duvalier, Jacques Vilgrain, and the Director of the Bureau de Nutrition, William Fougère (Fig. 10). The only

32. Lyndon B. Johnson, Address (4 January 1965), in the Public Papers of the President of the United States, vol. 2 (Washington, D.C.: Government Printing Office, 1966), 4.

33. Quoted by Donaldson in Nature Against Us, 89. Also see Randall Hansen and Desmond King, Sterilized by the State: Eugenics, Race, and the Population Scare in Twentieth-Century North America (New York: Cambridge University Press, 2013); Ian R. Dowbiggin, The Sterilization Movement and Global Fertility in the Twentieth Century (New York: Oxford University Press, 2008). 


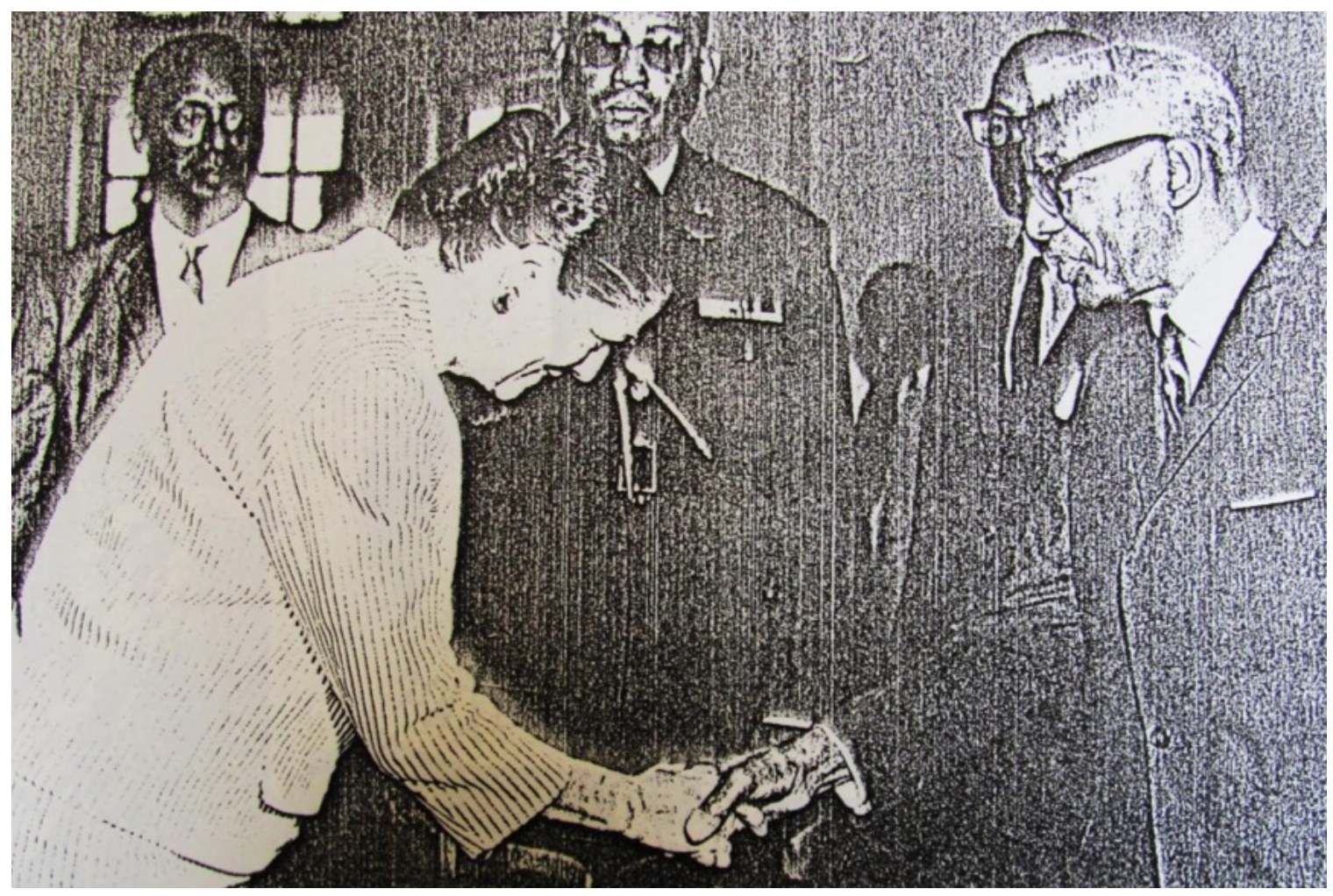

Fig. 10 Alice Sheridan, Spokeswoman of the Unitarian Universalist Service Committee with François Duvalier. From: Unitarian Universalist Service Committee Records, serial no. 16134, box 4: "Haiti Book." Andover-Harvard Theological Library, Harvard University, Cambridge, Massachusetts. Reproduced with permission.

person who expressed interest in collaboration, however, was Ary Bordes. ${ }^{34}$ That evening, Bordes visited Sheridan at the hotel where she was staying. "With fire in his eyes," he presented his vision to combine Western medicine, contraception, and education. ${ }^{35}$ Sheridan thought it was a viable way to prevent overpopulation

34. Memo on "UUSC-IIN Nutrition Seminars" (4 June 1965), USCR, serial no. 16134, box 4: "Haiti Book."

35. Ary Bordes, Un médecin raconte: une vie, une carrière (Port-au-Prince: Henri Deschamps, 1989), 118. 
without an imperialist intervention by the US government. She promised Bordes that the Service Committee would help in any way possible.

Unlike the Population Council and the Population Crisis Committee, which only cared about contraception, Bordes wished to revolutionize motherhood as a whole. He perceived peasant women as "primitive" and "negligent." The way they cooked and cleaned was supposedly hazardous to children, and when a child became ill and passed away, they wanted more, in hope that one would survive. "The more our mothers make children, the more they bury them," Bordes told Richard Steckel of the Service Committee. "What they [really] need [is] work, medical care, adequate housing, nutrition, [and] education with family planning." ${ }^{36}$

The proclivity to blame poverty on "unrestrained" black women was very common, especially in the US, where Cold War anxieties evoked social conservatism. ${ }^{37}$ In his widely-read report, "The Negro Family," Lyndon Johnson's Assistant Secretary of Labor, Daniel Patrick Moynihan, hypothesized that many African-American communities were stuck in poverty because women

36. Ary Bordes to Richard Steckel (2 September 1969), USCR, serial no. 16026, box 8: "Haiti, 1969, No. 2." Bordes' own emphasis.

37. Elaine Tyler May analyzes this phenomenon in Homeward Bound: American Families in the Cold War Era (New York: Basic Books, 1988). Also see David K. Johnson, The Lavender Scare: The Cold War Persecution of Gays and Lesbians in the Federal Government (Chicago: University of Chicago Press, 2006); Carolyn Herbst Lewis, Prescription for Heterosexuality: Sexual Citizenship in the Cold War Era (Chapel Hill: University of North Carolina Press, 2013). 
"emasculated" the men. ${ }^{38}$ Faced with discrimination in the workplace, AfricanAmerican men were unreliable breadwinners and prone to divorce, said Moynihan. Single mothers, he claimed, were overly "dominant" and "embittered" toward young men, who became weak and submissive. ${ }^{39}$

Many social scientists applied Moynihan's theory to Haiti. A professor at MIT, Robert Rotberg, insisted that Haitian mothers had raised a petulant, immature nation. Acquainted with Erik Erikson's work on psychosocial development, Rotberg psychoanalyzed Haiti's children, whom he described as "highly indulged." 40 Showered by their mothers' undivided attention, they "learn to expect immediate and intense physical gratification," he stated. As a result, "the Haitian boy is unready for justice, stunted in his appreciation of the meaning of moral responsibility and, during what [Sigmund] Freud called the latency period, he despairs of his own potency as an autonomous individual."

Scientists blamed Haitian population growth on women, who supposedly "lacked restraint." As explained by Paul Farmer, Americans commonly associated sex in Haiti with Vodou, blackness, poverty, and disease.$^{41}$ They

38. Daniel Patrick Moynihan, "The Negro Family: The Case for National Action" (Washington, D.C.: Department of Labor, Office of Policy Planning and Research, 1965).

39. Susan D. Greenbaum, Blaming the Poor: The Long Shadow of the Moynihan Report (New Brunswick: Rutgers University Press, 2015).

40. Robert I. Rotberg with Christopher K. Clague, Haiti: The Politics of Squalor (Boston: Houghton Mifflin, 1971), 19-20.

41. Paul Farmer, AIDS and Accusation: Haiti and the Geography of Blame (Berkeley: University of California Press, 1992). 
perceived it as immoderate, which made it potentially subversive. In a presentation sponsored by the Population Council, one sociologist, J. Mayone Stycos, declared that Haitians had "no cultural idea concerning the appropriate number of children." ${ }^{42}$ Stycos interviewed peasants in the countryside and reported that Haiti had 'a culture which we have scored 'zero' on each of the... necessary conditions for family limitation." Without an intervention, there was supposedly little hope that Haiti would limit procreation to "modern levels."

The intervention prescribed by Stycos came in 1965, when the Unitarian Universalist Service Committee teamed up with the Williams-Waterman Fund and the Foundation for International Child Health to provide 16,000 US dollars to Ary Bordes, who opened the Centre d'Hygiène Familiale in Port-au-Prince. "How did you arrive at the name?" Steckel inquired. "It sounds like a brilliant, if not somewhat undercover, euphemism for family planning" or a "Japanese family bath house." ${ }^{43}$ The euphemism, "family hygiene," Bordes explained, was less provocative than "population control."44

Initially, the CHF tried to collaborate with the Hôpital Général to distribute birth control, but the local pediatricians were not interested. Bordes thus went to

42. J. Mayone Stycos, "Experiments in Social Change: The Caribbean Fertility Studies," in Research in Family Planning, ed. Clyde V. Kiser (Princeton: Princeton University Press, 1962), 314-16.

43. Richard Steckel to Ary Bordes (4 April 1969), USCR, serial no. 16026, box 8: "Haiti, 1969, No. 1."

44. Ary Bordes to Richard Steckel (25 April 1969), same location as the previous citation. 


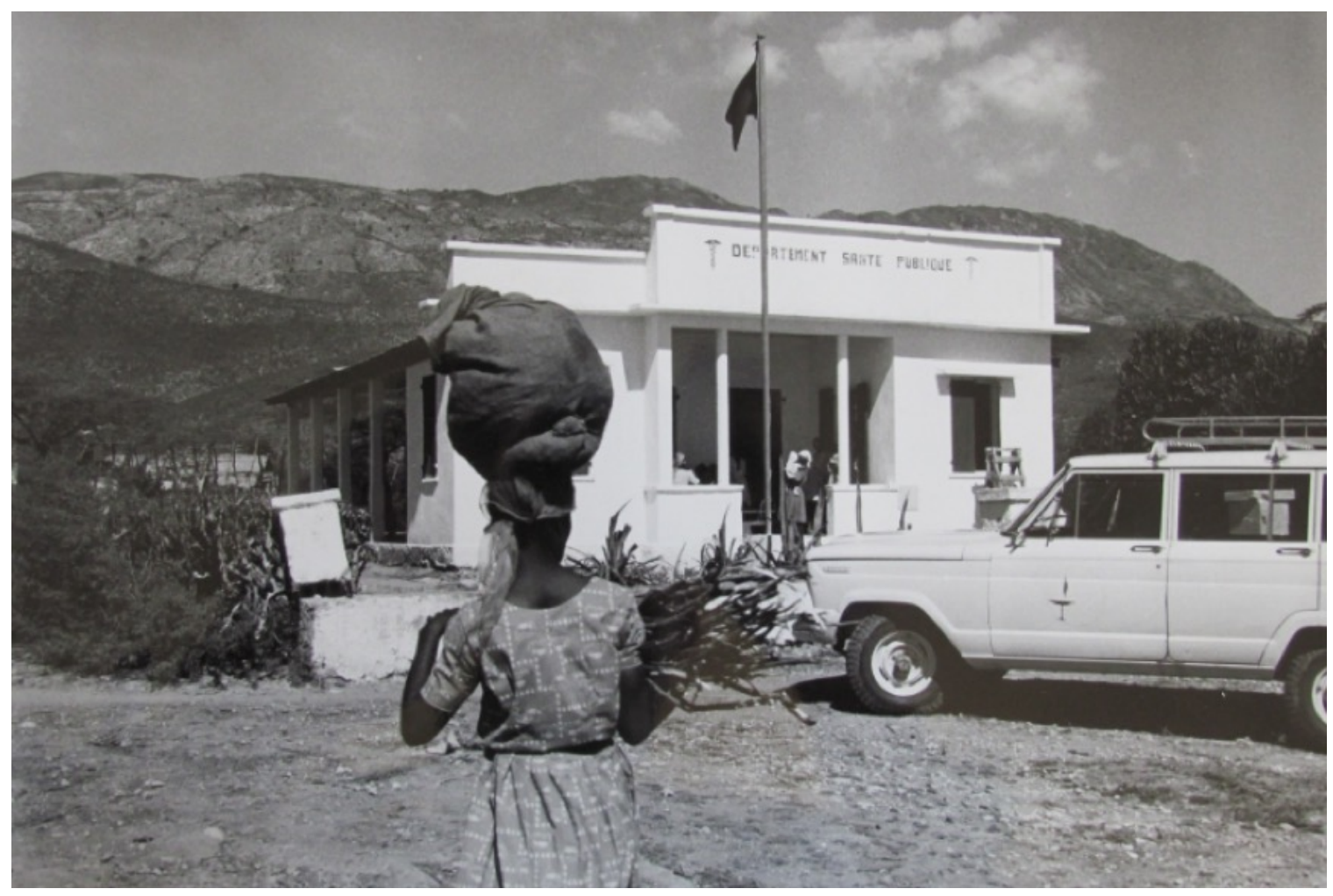

Fig. 11 The Centre d'Hygiène Familiale in Fond Parisien. From: Unitarian Universalist Service Committee Records, serial no. 16057, box 3: "Haiti, 19691974." Andover-Harvard Theological Library, Harvard University, Cambridge, Massachusetts. Reproduced with permission.

Fond Parisien, where the Bureau de Nutrition had built a small facility to promote a good dietary regimen. ${ }^{45}$ The Director of the Bureau, William Fougère, let Bordes use the space once a week to administer tetanus vaccinations. Impressed by Bordes' dedication, he insisted the physician transform the facility into a clinic and expand the CHF into Fond Parisien (Fig. 11).

45. Ary Bordes and Andrea Couture, For the People, For a Change (Boston: Beacon Press, 1978), 68. 
Bordes saw in Fond Parisien a suitable "laboratory" in which he and the Unitarian Universalists could develop new ways to educate peasants about Western medicine and contraception. The town had 4,000 residents who lived in mud brick huts, and 15,000 people inhabited the nearby hills. The men worked the land, but Hurricane Hazel (1957), Flora (1963), and Inès (1966) had destroyed the local irrigation system. ${ }^{46}$ The region was largely deforested. In the early twentieth century, the trees were cut down to create railroad tracks and electrical poles in Port-au-Prince. Ironically, the peasants had no electricity, so the women harvested wood and produced charcoal, which they used to cook and sold to make money. In summation, Fond Parisien was home to poverty and misery, which Bordes and the missionaries planned to address.

\section{Missionary Anti-Imperialists}

The Unitarian Universalist Service Committee supported Ary Bordes in Fond Parisien because it wanted to empower Haitian technicians. Richard Steckel's supervisor, John McAward, insisted that every nation should have the opportunity to choose its own destiny. "Development," he explained, must take place "on terms established by the developing nations." ${ }^{\text {"47 }}$ McAward's interest in

46. Bordes, Un médecin raconte, 149-50.

47. John McAward to Ary Bordes (9 May 1975), USCR, serial no. 16093, box 2: "Haiti, General, 1974-1977." 
national sovereignty evolved within the Unitarian Universalist Association (UUA), a spiritual community that tolerates most theological doctrines. Founded in 1961 when the Universalist Church of America and the American Unitarian Association merged, the UUA was relatively new, although Unitarianism and Universalism, as separate religions, were several hundred years old. Many members were converts who found Catholicism and Protestantism too overbearing. Others were castaways, excluded by mainstream religions. They saw in Haiti a history like their own: a people who escaped oppression to pursue a just society.

The Unitarian Universalists were staunchly opposed to political and economic imperialism—and they were not alone. Anti-imperialism had swept across the US during the Vietnam War, as Americans read subversive literature, like The Ugly American (1958) by Eugene Burdick and William Lederer. Some activists, McAward included, even joined the Peace Corps. Like Father Finian, a protagonist in The Ugly American, they traveled to Africa, Asia, and Latin America to live among the oppressed.

Richard Steckel was deeply involved in this movement. He wanted to do good in a time when the US had descended into moral ambiguity. In his correspondence with Bordes, Steckel condemned the "May 4" massacre at Kent State University, where the Ohio National Guard killed four students who protested the invasion of Cambodia. ${ }^{48} \mathrm{He}$ criticized pilots who bombed innocent

48. Richard Steckel to Ary Bordes (15 December 1970), USCR, serial no. 16026, box 12: "Haiti, 1970, No. 1." 
civilians and complained when police arrested a woman simply because she wore a US flag over her backside. The US ceased to make any sense; hence, there was a "revolution," Steckel proclaimed. "This revolution acts on the assumption that nothing is sacred in today's society. Institutions, values, mores, etc., should and must be questioned as to their relevancy in today's world. ${ }^{39}$

Steckel was not as extreme as some Unitarian Universalists.

Nevertheless, he tried to convey to Bordes the extent to which the insurrection had spread. "American... capitalism [and...] imperialism [are...] the patient being dissected," he declared. They are "generally viewed as a sick entity." people think that "the system has broken down or at least is so protective, insulated, and well defended that to work within it is choking." Steckel did not know where the revolution was headed, but "I certainly am not depressed by events," he told Bordes. "Exhilarated, yes; pained at times, yes; frightened at times, yes, but depressed, no!" Steckel promised Bordes that he would explain everything as soon as they were together, "sitting under a mango tree, sipping Haiti's lip-smacking tropical drinks, or in the quiet of a home with our shoes off."

Steckel and Bordes had many such discussions. They built a close partnership based on mutual trust and anti-imperialism. Haiti aside, no topic

49. Ibid.

50. Ibid.

51. Richard Steckel to Ary Bordes (4 June 1969), USCR, serial no. 16026, box 8: "Haiti, 1979, No. 1." 
inspired solidarity more than the Nigerian Civil War, which erupted in 1967. While Britain and the Soviet Union armed the Nigerian government and the US remained neutral, Steckel and Bordes supported the Biafran separatists, who were slowly starved into submission. "We share the immense sense of tragedy which has befallen the hundreds of thousands who innocently suffer in any conflict," Steckel wrote Bordes. ${ }^{52}$ Naturally, Biafra's story—a black independence movement against multiple imperial powers—resonated with the Haitian people. Bordes was happy to inform Steckel when President François Duvalier sided with the Biafrans. ${ }^{53}$ In 1969 , Steckel travelled to Biafra to see the war with his own eyes. He then reported to Bordes, describing "the horror and hope" in "that tortured country." 54

Convinced that the US had lost its way, Steckel sought redemption by serving as Bordes' loyal intermediary with contraceptive suppliers. Bordes needed birth control pills, so Steckel went to the Pathfinder Fund, where he retrieved Ovulen Fe 28. He then visited the Upjohn Company to request Depoprovera and the Schering Company to acquire Gynovlar. ${ }^{55} \mathrm{He}$ approached

52. Richard Steckel to Ary Bordes (30 April 1969), Bordes to Steckel (27 March 1969, 14 May 1969), same location as the previous citation.

53. Ary Bordes to Richard Steckel (25 April 1969), USCR, serial no. 16026, box 8: "Haiti, 1969, No. 1."

54. Richard Steckel to Ary Bordes (6 March 1969), same location as the previous citation.

55. Ary Bordes, "Family Planning in Haiti: The UUSC Approach" (1970), 42, USCR, serial no. 16093, box 2: "Haiti, Family Planning, No. 1." 
the Population Council to obtain intrauterine devices and asked the Church World Service to supply Bordes with contraceptive cream and a film about birth control by Walt Disney. ${ }^{56}$

Requests and supplies went back and forth. Bordes compared the exchange to a match of table tennis. Except the table was "three sided!" Steckel laughed. ${ }^{57}$ Occasionally, Steckel had to chivvy the suppliers. "Pathfinder has not written [us] yet about the pills," he told Bordes. "We will push them a bit.... The word is 'goose them'... if you want to be fully Americanized!"

Steckel also kept an eye on anyone who might have threatened Bordes' autonomy. He noted how the director of Pathfinder had "wryly smiled" and said, '“you have a very good project under Dr. Bordes' supervision.' What he really meant," Steckel joked, was “I wish Pathfinder could be its father!' Oh well, I guess we have to live in a green-for-envy world. ${ }^{\text {"59 }}$ Steckel knew that the CHF would eventually have to stand on its own. For the time being, however, he hoped to cultivate a respectful relationship with external organizations. ${ }^{60}$

56. 16mm film, "Family Planning" (no date), Population Council Library, Audiovisual Collection, New York, New York.

57. Richard Steckel to Ary Bordes (17 November 1970), USCR, serial no. 16026, box 12: "Haiti, 1970, No. 1."

58. Ibid.

59. Richard Steckel to Ary Bordes (21 April 1970), USCR, serial no. 16026, box 12: "Haiti, 1970, No. 2."

60. Richard Steckel to Ary Bordes (9 May 1969), USCR, serial no. 16026, box 8: "Haiti, 1969, No. 1." 
The Unitarian Universalists worried that William Draper of the Population Crisis Committee would learn about the clinic in Fond Parisien and try to seize control. Unfortunately, Draper discovered "La marée humaine" by Préfète Duffaut when McAward asked his associate in New York to make copies. Draper immediately insisted that the CHF join IPPF. The associate telephoned McAward to notify him about a possible "power play" by Draper. He testified that "[Draper] pushes IPPF all the time and is not very sensitive to host country sensibilities." McAward immediately contacted Bordes. "We wanted to warn you [that] Draper is not known for his sensitivity to non-Americans, nor is he tuned in to the general development philosophy that goes hand in hand with family planning [in Haiti]." McAward promised that the Service Committee "fully support[s] your independence and will gladly tell Draper anything you direct us to say in support of your decision." ${ }^{n 2}$

Steckel and McAward protected Bordes' autonomy because they trusted him to develop a viable prototype that the Service Committee could promote elsewhere in the world. Founded in 1939 to help the victims displaced by World War II, the Service Committee was active throughout Africa, Asia, and Latin America, where it provided medicine, shelter, and education to impoverished

61. John McAward, "Phone Call with Hal Crow" (5 June 1974), USCR, serial no. 16093, box 2: "Haiti, General, 1974-1977."

62. John McAward to Ary Bordes (4 June 1974), same location as the previous citation. 
communities. Steckel and McAward believed population control would compliment the Committee's endeavors. ${ }^{63}$

They were especially impressed by Bordes' emphasis on women's "empowerment." McAward insisted that "there must be an alternative role for women other than wife and mother-even in Haiti. ${ }^{164}$ Bordes promised him that contraception would enable them to "replace periods of unwanted pregnancy with paid work." ${ }^{\prime 5}$ Toward this end, the CHF lent 400 US dollars to women in Fond Parisien who wanted to produce tomato paste. ${ }^{66}$ It also sponsored local cooperatives and invited women to participate.

Convinced that Bordes had discovered the elusive "third way," the Service Committee invited the top experts on public heath in the Caribbean to Fond Parisien in 1976. McAward showed them the CHF, hoping they would copy it. ${ }^{67}$ While the Trinidadians dismissed Fond Parisien as "pathetic," the Surinamese

63. UUSC, "Thoughts on Beginning of Program to Replicate the Haiti Project" (no date), USCR, serial no. 16093, box 2: "Haiti, General, 1974-1977."

64. John McAward, "Evaluation of the UUSC Program in Haiti" (1974), 5, General Service Foundation Records (GSFR), box 14: "UUSC, Family Planning Program, Haiti, 1973-1976," 653. Minnesota Historical Society, Saint Paul, Minnesota.

65. CHF, Laboratoire interdisciplinaire de médecine communautaire et de planification familiale (1973), 155, USCR, serial no. 16093, box 1: "Haiti, Family Planning, No. 2."

66. Bordes and Couture, 227.

67. UUSC, "Workshop in Haiti for English-Speaking Family Planning and Health Professionals from the Caribbean Area" (1976), 7, USCR, serial no. 16093, box 4: "Haiti, Workshop, Family Planning." 
expressed interest. ${ }^{68}$ Bordes quickly reached out to them. "I would appreciate to spend my time in sharing with you [my] experience in public health," he told one Surinamese physician. He vowed to visit Suriname to "discuss the possibility of a proposal to [the Service Committee]."

The Unitarian Universalists noted how Bordes' "strateg[y] for [the] integration of maternal and child healthcare, family planning, and community development [made him] a most capable person to advise other Third World nations.. ${ }^{70}$ Hence, they hired him as a consultant in Benin, where USAID had broken its promise to build a hospital. Bordes helped the local community open a clinic. Like the CHF in Fond Parisien, it provided healthcare, birth control, and education to mothers. ${ }^{71}$ The Unitarian Universalists were very pleased. They believed Bordes would show nations like Benin the way to utopia.

68. UUSC, "Workshop in Haiti for Family Planning" (1976), 11, same location as the previous citation.

69. Ary Bordes to B.F.J. Oostburg (8 November 1977), USCR, serial no. 16093, box 4: "Haiti, Workshop, Correspondence."

70. Elizabeth Coit to John McAward (no date), USCR, serial no. 16093, box 2: "Haiti, Family Planning, No. 2."

71. Elizabeth Coit, "Health from Haiti to West Africa," (no date), 6, USCR, serial no. 16125, box 4: "Haiti, Heath Centers." 


\section{Medical Impositions}

Although the Unitarian Universalists desired a just society, they enabled Ary Bordes to impose his own ideas about medicine and contraception on the peasants in Fond Parisien. Bordes was no ordinary Haitian. To the contrary, he was trained to promote Western medicine by the Ecole Nationale de Médicine. Built in the early nineteenth century, the Ecole Nationale preserved the medical knowledge introduced by the French colonizers. ${ }^{72}$ The US renovated the school in the 1920s, when Marines occupied the country, and the Rockefeller Foundation provided scholarships to Bordes' teachers so they could study medicine in the US. ${ }^{73}$ Upon graduation, Bordes went to Johns Hopkins, where he obtained a master's degree in public health. His goal was to work in the Ministère de la Santé Publique, which was built upon the Service National d'Hygiène created by the US in 1917.

Guided by the utopian impulse, Bordes wished to transcend the political and economic structures that kept Haiti in poverty, but he largely operated within

72. In his book, History of Haitian Medicine (New York: Paul B. Hoeber, 1930), 66-67, Robert P. Parsons observes how "in 1820 a commission was appointed to control medical education." Finally, "in 1838 the [training] school at [the hospital in] Port-au-Prince was reorganized and given the name, 'Ecole Nationale de Médicine." Also see Ary Bordes, Evolution des sciences de la santé et de I'hygiène publique en Haïti (Port-au-Prince: CHF, 1979); Catts Pressoir, Le médecine en Haïti (Port-au-Prince: Imp. Modèle, 1927); Rulx Léon, Pratique médicale à St.-Domingue (Paris: Presses Modernes, 1928).

73. Ary Bordes, Haïti: médecine et santé publique sous l'occupation américaine, 1915-1934 (Port-au-Prince: Henri Deschamps, 1992), 115-18. 
the institutional and ideological structures of Western medicine. He was hostile toward the peasantry's Afro-Caribbean healthcare system. As explained by Karol Weaver, the French built hospitals in colonial Saint-Domingue. These institutions, however, primarily served the colonizers. The enslaved population turned to enslaved healers: midwives, mesmerists, herbalists, and women hospitalières, who maintained the plantation clinic. ${ }^{74}$ Enslaved healers mixed African and Creole rituals and remedies with the colonizers' medicine to create the system inherited by Haiti's fanm saj (wise women), ougans (Vodou priests), and docteurs-feuilles (leaf doctors). ${ }^{75}$ While the average peasant interpreted this system and Western medicine as complimentary, Bordes believed they were mutually exclusive.

Bordes disliked how Catholicism and Vodou attributed illnesses to immorality and malice when science had proven that they were caused by malnutrition, bacteria, and viruses. As noted by anthropologist Paul Brodwin, many peasants perceived a sickness with no known remedy as unnatural or

74. Karol K. Weaver, Medical Revolutionaries: The Enslaved Healers of Eighteenth-Century Saint Domingue (Urbana: University of Illinois Press, 2006).

75. Jean-Claude Delbeau analyzes extra-sensory, ethno-spiritual, and cosmic knowledge about the body in Société, culture et médecine populaire traditionnelle (Port-au-Prince: Henri Deschamps, 1990). Also see Alfred Métraux, "Médecine et Vaudou en Haïti," Acta Tropica 10, no. 1 (1953): 28-68; Odette M. Rigaud, "Les effets pratiques de la magie vaudou comme médecine rituelle," in La tradition voudoo et le voudoo haïtien: son temple, ses mystères, sa magie, ed. Milo Rigaud (Paris: Niclaus, 1953). 
supernatural. ${ }^{76}$ They interpreted a fever as a curse invoked by a rival or a Iwa (spirit). Hence, they turned to an expert on the supernatural: a Catholic priest or an ougan. Bordes complained when peasants blamed illnesses on envy, malevolence, and "dark and invisible forces." Those ideas "endlessly complicate life in the countryside," he lamented. They "prevent any penetration by modern scientific ideas." 77

Bordes noted how the peasantry's Afro-Caribbean healthcare system was unable to contain tetanus, a deadly disease caused by a bacterial infection. Tetanus killed one in ten newborns in Fond Parisien and was a principle reason why parents wanted to have so many children. ${ }^{78}$ The only way to limit population growth, Bordes explained, was to eliminate the disease. Aided by the Unitarian Universalists, the CHF hired local women and trained them as midwives. Each "matron," as they were called, took an 18-week course at the clinic, where they learned how to administer vaccines and use antiseptics to sterilize tools. ${ }^{79}$ Thanks to the matrons, tetanus in Fond Parisien was quickly eradicated.

76. Paul Brodwin, Medicine and Morality in Haiti (New York: Cambridge University Press, 1996), 14. Also see Paul Farmer, "Sending Sickness: Sorcery, Politics, and Changing Concepts of AIDS in Rural Haiti," Medical Anthropology Quarterly 4, no. 1 (Mar. 1990): 6-27; Gerald F. Murray, "Women in Perdition: Ritual Fertility Control in Haiti," in Culture, Natality, and Family Planning, eds. John F. Marshall and Steven Polgar. (Chapel Hill: Carolina Population Center, 1976).

77. Bordes, Un médecin raconte, 35-39.

78. Bordes and Couture, 99.

79. CHF, "Entrainement des matrones" in Laboratoire interdisciplinaire, 141-44. 
Emboldened by its victory over tetanus, the CHF became increasingly intrusive in Fond Parisien. Its next opponent was the fanm saj. Bordes observed how the "wise woman" prayed to the Iwa Marassa, the divine twins of Vodou, when she delivered a child. ${ }^{80}$ Bewildered by such practices, he tried to distinguish between "useful" mētis that he would "encourage," inconsequential or "neutral" beliefs that he would "tolerate," and "harmful" ones that he would try to "uproot." He advised the women in Fond Parisien to avoid fanm saj who were not certified by the clinic. ${ }^{81}$ "Ignorant matrons," he explained, "will be replaced more and more by women who have received instruction and eventually by medical auxiliaries, nurses, or [reformed] midwives. Soon no woman will be able to work as a matron unless she has been trained.."82

Meanwhile, the $\mathrm{CHF}$ tried to convince mothers that contraception was virtuous and healthy. Toward this end, Bordes hired several nurses to counsel women at the clinic. Each nurse received a massive guidebook that told them how to talk to mothers about birth control. "At the prenatal consultation," it stated, "make sure that the mother-to-be knows where to find the family planning clinic," and "insist that the [she] avoid another pregnancy for two or three years." ${ }^{83}$ If a

80. Bordes and Couture, 15-16. The movie, "Madam Tizo" (2004), by David Belle, provides a close look at the fanm saj. Also see Marilise Rouzier, La médecine traditionnelle familiale en Haïti (Port-au-Prince: Editions de l'Université d'Etat d'Haïti, 2008).

81. Bordes and Couture, 111-12, 145.

82. CHF, "Entrainement des matrones," in Laboratoire interdisciplinaire, 145.

83. CHF, "La planification familiale," in Laboratoire interdisciplinaire, 75-76. 
woman already had three children, the nurse would emphasize how they are costly and explain how pregnancy "hinders" work. The nurse would then recommend birth control and help the patient choose a contraceptive.

To convey Bordes' message as clearly as possible, the CHF produced educational "syllabaires." Bordes even hired an artist, Edith Hollant, to illustrate them. Convinced that peasants would best understand contraception through symbolism, Hollant sketched a hollow calabash to represent a woman's womb. In the booklet, "I Want to Be Sterile," she portrayed a woman happily relaxing with the empty calabash. ${ }^{84}$ Additional syllabaires, such as "I Take the Pill," showed how to use birth control. Bordes delivered the booklets to Steckel, who asked the Pathfinder Fund to make as many copies as possible. "Next to the Gideon Bibles found in hotel rooms will most certainly be the syllabaires," Steckel jested. "I don't mean to be irreverent, but [l] wonder which has [the] most practical application at those "critical times."'85

The CHF soon expanded into nearby communities. Bordes was greatly amused by one operative who traveled to neighboring Croix des Bouquets and shouted the names of women who should visit the clinic in Fond Parisien ${ }^{86}$ To

84. "Je préfère le stérilet" (no date), USCR, serial no. 16026, box 15: "Haiti, Centre d'Hygiène Familiale."

85. Richard Steckel to Ary Bordes (3 March 1970), USCR, serial no. 16026, box 12: "Haiti, 1970, No. 2."

86. Ary Bordes, "General HCH and Family Planning Activities" (no date), 3 , GSFR, box 14: "UUSC, Family Planning Program, Haiti, 1973-1976," 653. 


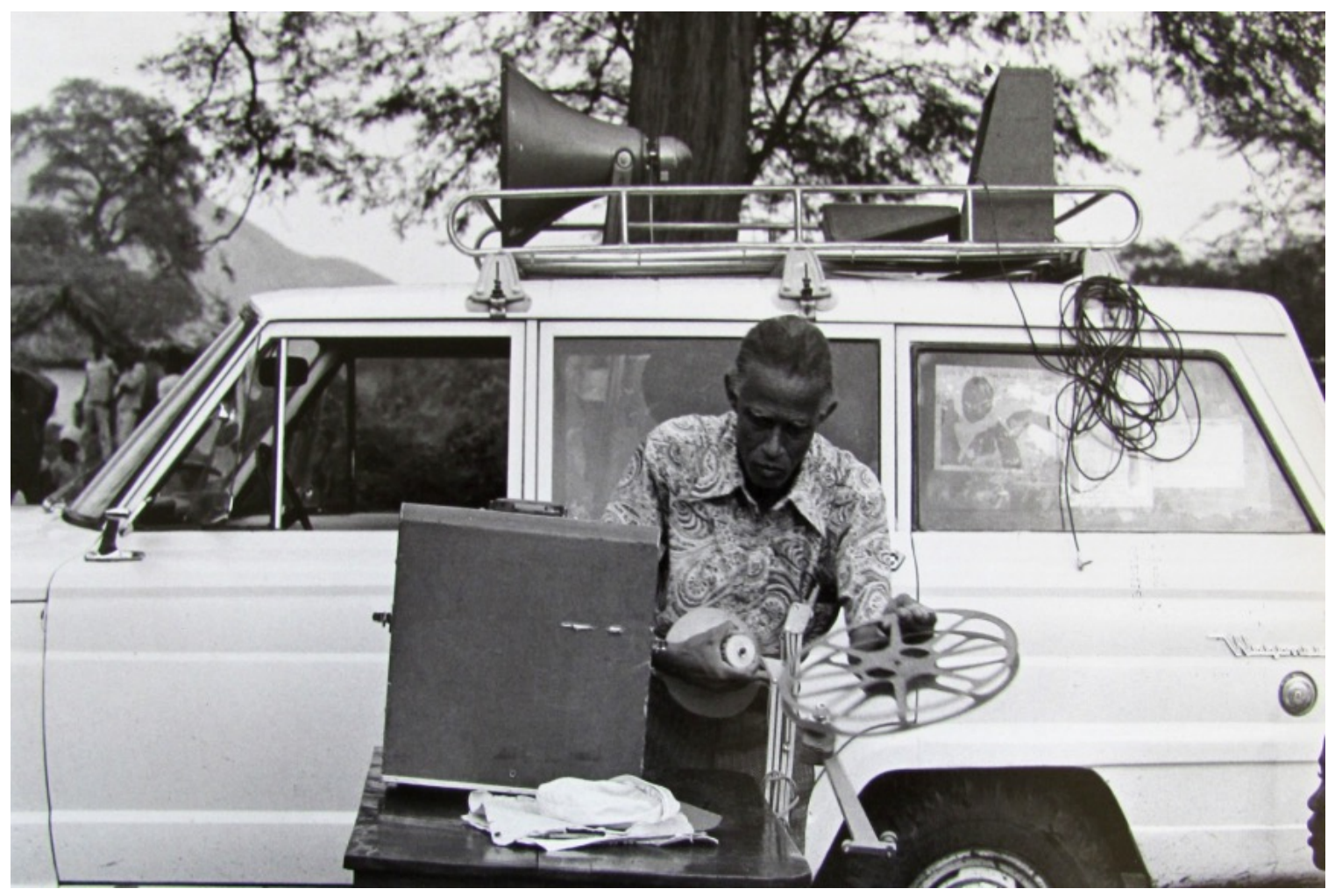

Fig. 12 CHF Wagoneer and Movie Projector. From: Unitarian Universalist Service Committee Records, serial no. 16057, box 3: "Haiti, 1969-1974." Andover-Harvard Theological Library, Harvard University, Cambridge, Massachusetts. Reproduced with permission.

lend a hand, the Unitarian Universalists purchased a 1967 Wagoneer and mounted a loudspeaker on the roof (Fig. 12). Meanwhile, the clinic employed "community agents," who went house to house, "persuading" women to "avoid pregnancy." ${ }^{87}$

As the CHF quickly discovered, however, women were not easily swayed. Bordes' own statistics reveal that only one in 18 visits by a community agent persuaded a woman to accept birth control. 715 women took contraception in

87. CHF, "La planification familiale," in Laboratoire interdisciplinaire, 76. 
Fond Parisien between 1966 and 1975, but as many as 25 to 50 percent quit within several months. ${ }^{88}$ Bordes assumed that women declined birth control because they "lacked education." He noted, however, that many believed contraception would permanently "wreck their nature." ${ }^{89}$ As explained by Timothy Schwartz, peasants generally wanted children. In the countryside, children were valuable assets, because they worked in and outside the home. ${ }^{90}$ Young children could become a burden, as Bordes warned. In desperate times, however, parents could always send a child to live and work in a relative's home as a "restavek," which is to say, a child servant.

Bordes was nonetheless determined to implement population control. He hired musicians and actors to incorporate contraception into a theatrical performance that would appeal to the locals. Dressed as peasants with Panama hats, the troupe went on stage. They beat drums and sang, "Y’apé bann gnou éducation," "we are educated," "qu'apé mété nou tout en fôme," "and will use all we know," "pou nou évolué, nan communoté, plus civilisé," "to improve our community."

88. Bordes and Couture, 143-45, 289.

89. Ibid., 82, 109.

90. Timothy T. Schwartz, Fewer Men, More Babies: Sex, Family, and Fertility in Haiti (Latham: Lexington Books, 2009) and "'Children are the Wealth of the Poor:' High Fertility and the Organization of Labor in the Rural Economy of Jean Rabel, Haiti" (Ph.D. Dissertation: University of Florida, 2000).

91. Edith Hollant, "Musical," in "Media folklorique dans l'éducation pour la santé," USCR, serial no. 16093, box 3: "Project Reports, No. 2." 
The clinic also tried to instill neo-Malthusianism into the children of Fond Parisien. It gave them a booklet, "D'ici l'an 2000," that showed one happy individual to represent the country's 500,000 residents in 1804 and 14 wretched paupers to signify the estimated 7 million people who would inhabit the country by 1980 . Hopefully, by the year 2000 , the booklet stated, Haiti would have newly paved streets, busy factories, and universal education, but population control was necessary to make this dream a reality. ${ }^{92}$

The clinic distributed a second booklet, "Quand nous serons grands," that conveyed the same point. It included children who sang, "when we grow up, we will have only two children, two children, two children!" In the end, they indeed had only two children, and "the village became the most prosperous in the nation, with beautiful green fields and happy, healthy children, who continued to sing the song of deux enfants." ${ }^{93}$ When Steckel visited Haiti, the CHF summoned the children of Fond Parisien to chant the lyrics in the booklet (Fig. 13). Inspired by the display, Steckel exclaimed, "may the song's spirit—and message—be heard widely and practiced. Two children, two children... the way for the future!"94

92. "D'ici l'an 2000" (no date), USCR, serial no. 16026, box 15: "Haiti, Centre d'Hygiène Familiale."

93. "Quand nous serons grands" (no date), same location as the previous citation.

94. Richard Steckel to Bonne Etoile Moline (14 July 1970), USCR, serial no. 16026, box 12: "Haiti, 1970, No. 2." 


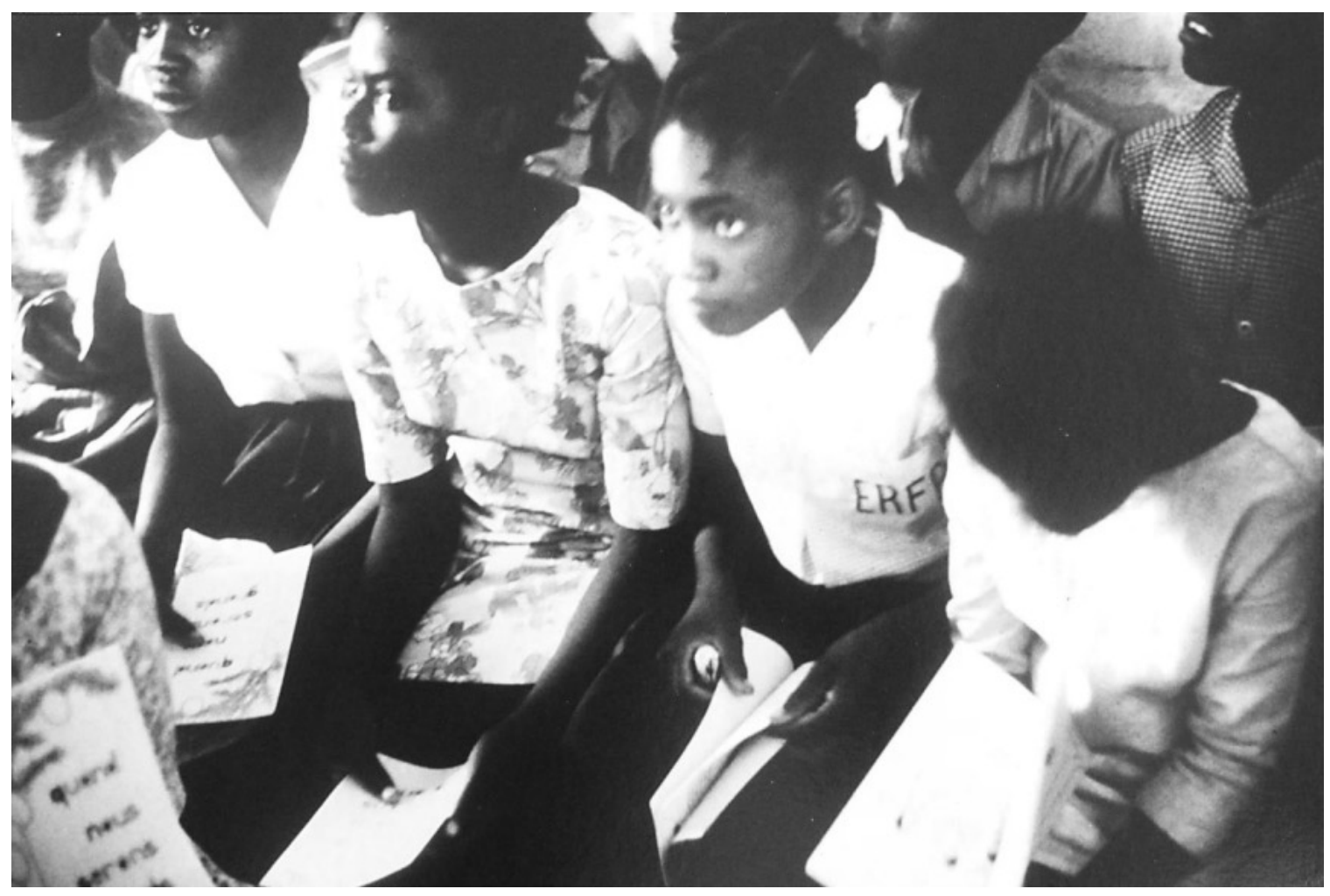

Fig. 13 Children with "Quand nous serons grands." From: Unitarian Universalist Service Committee Records, serial no. 16057, box 3: "Haiti, 1969-1974." Andover-Harvard Theological Library, Harvard University, Cambridge, Massachusetts. Reproduced with permission.

Bordes' insistence on birth control inevitably led to a confrontation with the Catholic Church. Much like the Vatican, the Church hierarchy in Haiti condemned contraception as an attack on God's creation. When the bishops learned about the $\mathrm{CHF}$, they notified local priests, expressing concern. ${ }^{95}$ Bordes wanted the Church to step aside but told his employees not to provoke it. In his guidebook,

95. Bordes mentioned this in the clinic's Tri-Monthly Report (January-March 1974), USCR, serial no. 16093, box 1: "Bordes, Correspondence, 1974-1976." Also see L'enfant, la famille, la société haïtienne (Port-au-Prince: Imp. de La Phalange, 1980) by the Archbishop of Port-au-Prince, François-Wolff Ligonde, who summarized the Church's position on social issues. 
he emphasized that peace with the community was "indispensable." Catholic priests, Vodou priests, even Tonton Macoutes were allowed to protest outside the clinic in hope that they would listen to Bordes' message. ${ }^{96}$

In 1974, a Catholic priest in a nearby town denounced the CHF, so Bordes invited him to participate in a public debate. Allowed to speak his mind, the priest confessed that he was not entirely opposed to population control. Nevertheless, he believed women should avoid contraceptives and instead use a thermometer to determine when not to have sex. ${ }^{97}$ Bordes was unable to convince him otherwise, but Steckel was nonetheless pleased. "With this kind of discussion," he was certain that "it won't be long before [the] Catholic Church will remove obstacles standing in the way of progress for the Haitian people." 98

Steckel was well aware that many people interpreted population control as imperialist. In his correspondence with Bordes, he lamented how contraception was perceived as a means to do away with impoverished populations, especially non-whites. Steckel insisted they were mistaken. In response, he compiled an extensive list of moral authorities who supported birth control and was sure to include the leaders of non-white nations, such as Ghana and Nigeria. ${ }^{99} \mathrm{He}$ also

96. CHF, "Aspects social," in Laboratoire interdisciplinaire, 21-22.

97. CHF, Tri-Monthly Report (January-March 1974), 4.

98. Richard Steckel to Ary Bordes (29 April 1974), USCR, serial no. 16093, box 1: "Bordes, Correspondence, 1974-1976."

99. UUSC, "International Quotes on Family Planning" (no date), USCR, serial no. 16026, box 3: "Haiti, 1966-1968." 
transcribed the statement by Martin Luther King, Jr., that family planning was "possible, practical, and necessary." ${ }^{100}$ With Africa and the African-American Civil Rights Movement on his side, Steckel was ready to proceed as planned.

\section{A Lesson in Motherhood}

Ary Bordes believed that Western medicine and contraception would "liberate" and "empower" Haitian mothers. To convey this message, he introduced Bernadette, a make-believe woman whose many tribulations were "the consequence of [having] too many children." ${ }^{\text {"101 }}$ Bernadette was penniless and had already lost a son to malnutrition. Once again, she was pregnant, Bordes explained, but she was already exhausted. "She lost weight" and "had no strength." As a result, "Bernadette neglected her home," which was "dirty" and "sad." 102 Bordes presented his audience with a series of illustrations that showed Bernadette, dismayed and overwhelmed, resting on a chair. A broom was lying on the unswept floor, and rats were scurrying through a hole in the wall. The moral of the story was hardly subtle: women who reproduced "excessively" were unable to fulfill their responsibilities. Fortunately, when Bernadette's next child

100. Ibid.

101. CHF, "Introducing Bernadette and Henri of Haiti" (1974), same location as the previous two citations.

102. CHF, "Henri and Bernadette" (no date), USCR, serial no. 16093, box 1: "Haiti, 1966-1969." 
was born, she discovered the CHF, which supplied her with birth control and taught her how to cook and clean.

Determined to help women like Bernadette, Bordes assembled a curriculum on "mother-craft" that began with a lesson on child rearing. In Fond Parisien, child malnutrition or "kwashiorkor," as the peasants called it, was widespread, so Bordes showed mothers how to breastfeed healthy children. He presented them with educational films made in the US. McAward noted how one movie portrayed the work of an African-American midwife in Georgia. ${ }^{103}$ Another, by La Leche League, featured white, middle class women breastfeeding. The message, McAward explained, was that "if the Americans with their sophisticated health systems are returning to [breast feeding] then it must be the best method." ${ }^{104}$

Bordes also told mothers how to cook. He insisted they make acamil, the dietary staple recommended by the Bureau de Nutrition. As the Bureau explained in its recipe book, acamil is a mixture of two parts rice or corn and one part peas or beans. "It is true that the proteins in milk or eggs are better than those in corn or rice, or beans," the Bureau admitted, "but that does not mean that the protein in these cereals is worthless." To the contrary, it contains "amino acids that are

103. John McAward, "Evaluation of the UUSC Program in Haiti" (1974), 5 , GSFR, box 14: "UUSC, Family Planning Program, Haiti, 1973-1976," 653.

104. John McAward to the New Internationalist Stage House (25 March 1975), USCR, serial no. 16093, box 2: "Haiti, General, 1974-1977." 
very important." ${ }^{\text {105 }}$ Bordes endorsed the Bureau's recommendations and included acamil in his guidebook, which described in detail what mothers should cook. ${ }^{106}$ At the clinic in Fond Parisien, employees demonstrated how to make the mixture.

In addition to malnutrition, stomach viruses killed numerous children in Haiti and were a reason why parents wanted more kids. The only way to stop these viruses, Bordes reckoned, was to "educate mothers about sanitation."107 Hence, the CHF instructed mothers to wash their homes with bleach and keep chickens, goats, and pigs outside. ${ }^{108}$ It also provided advice on sanitation in its monthly bulletin, which included explanatory illustrations. Distributed throughout Fond Parisien by Bordes' community agents, the bulletin pleaded, "help protect us against pests!" It stressed: "do not let flies invade your home" because "they rest on trash," and "their feces will contaminate our food and make us sick." 109

To improve public heath and hygiene, Bordes asked his employees to set up a "sanitation booth" in the nearby marketplace, where they would "educate"

105. Bureau de Nutrition, Acamil A-K-1.000 (1978), 2-3, Boston Women's Health Book Collective Records (HBCR), box 93: "International: Haiti," 8. Radcliffe Institute, Arthur and Elizabeth Schlesinger Library on the History of Women in America, Harvard University, Cambridge, Massachusetts.

106. CHF, Laboratoire interdisciplinaire, 56-58.

107. Ibid., 66 .

108. CHF, Syllabaire de la femme enceinte et de la nouvelle accouchée" (no date), 7, USCR, serial no. 16093, box 3: "Haitian Painting."

109. CHF, Nouvelles de Fond-Parisien 1, no. 3 (May 1970): 4, USCR, serial no. 16026, box 15: "Haiti, Centre d'Hygiène Familiale." 
the women merchants. ${ }^{110} \mathrm{He}$ also recruited two radio personalities, Fanny and $\mathrm{Ti}$ Djo, who spoke to audiences about "mother-craft."111 Worried that no one would listen to the broadcasts, Bordes had CHF technicians visit every house in Fond Parisien to make sure the residents owned a radio. ${ }^{112}$

Explicit in the term "mother-craft" was the assumption that work in the home was exclusively women's responsibility. The clinic thus perpetuated the idea that housework was "travay fanm," i.e. "women's work." In every booklet and syllabaire, it portrayed women in the home. Mothers were the ones who took care of the children, cooked, swept, emptied chamber pots, cleaned dishes, did laundry, and sewed clothes. ${ }^{113}$ Meanwhile, in the Syllabaire du père, the handbook given to men, the husband apparently had no responsibilities in the home except to take his wife to the clinic and make sure they used contraception. ${ }^{114}$

Raised in a nation where women normally worked with pots and pans while men wielded a hoe and machete, Bordes and his male colleagues would

110. CHF, Laboratoire interdisciplinaire, 113.

111. Edith Hollant, "Description of Radio Docteur, Health Education Radio Program of the Centre d'Hygiène Familiale" (1977), 2, Development Communications Archive (DCOA), box 95: "Radio Docteur," 201. Dolph Briscoe Center for American History, University of Texas, Austin, Texas.

112. Ary Bordes, "A Fruitful Year" (1973), 6, GSFR, box 14: "UUSC, Family Planning Program, Haiti, 1973-1976," 653.

113. CHF, Syllabaire de la femme enceinte et de la nouvelle accouchée.

114. CHF, Syllabaire du père (no date), USCR, serial no. 16026, box 15: "Haiti, Centre d'Hygiène Familiale." 


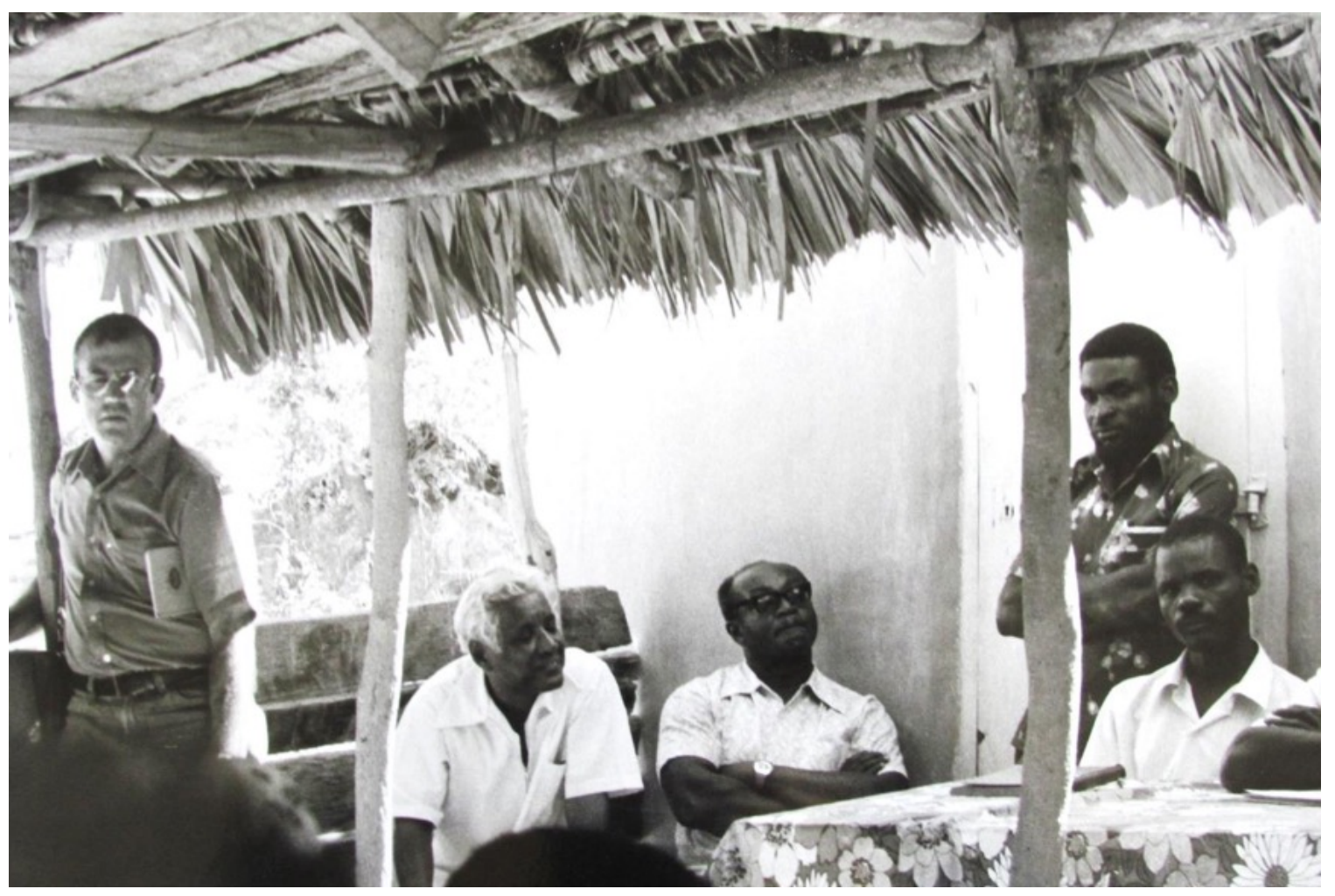

Fig. 14 Ary Bordes (white hair), Haitian Physician. From: Unitarian Universalist Service Committee Records, serial no. 16057, box 3: "Haiti, 1969-1974." Andover-Harvard Theological Library, Harvard University, Cambridge, Massachusetts. Reproduced with permission.

not contemplate any alternative division of labor (Fig. 14). As explained by anthropologist Ira Lowenthal, Haitian men rarely cooked or cleaned: "gason pa fèt pou fè yo." When a man did "travay fanm," everyone said he was a "makòme," a handmaiden or homosexual. Lowenthal notes how men sometimes liked to claim that they helped with the children, but in reality, they usually left this responsibility to women. ${ }^{115}$

115. Ira P. Lowenthal, "Marriage is 20, Children are 21: The Cultural Construction of Conjugality and the Family in Rural Haiti" (Ph.D. Dissertation: Johns Hopkins University, 1987), 54-60. 
Given the clinic's emphasis on women's empowerment, the Unitarian Universalists thought it should provide daycare and a nanny service to mothers. Bordes, however, was dismissive. Daycare was "too complicated and expensive," he said, and a nanny would raise "questions of responsibility." ${ }^{116}$ The missionaries trusted Bordes' intuition but expressed disappointment when the women in Fond Parisien were too busy in the home to participate in $\mathrm{CHF}$ cooperatives. "One woman told us 'm'esklav [I am a slave],"' they lamented, "because she spends so much time taking care of her home and children that she has no time to even come to preliminary meetings." 117

\section{Divisions}

In 1971, Bordes was given an opportunity to promote his vision on a national scale. In late April, President François Duvalier passed away and his son, Jean-Claude, appointed Bordes' former classmate, Alix Théard, as Ministre de la Santé. Théard summoned Bordes to Port-au-Prince and insisted he lead a new Division d'Hygiène Familiale modeled on the CHF. ${ }^{118}$ The Division would implement a national family planning program in clinics throughout the country.

116. UUSC, Untitled Report (no date), 18-19, USCR, serial no. 16122, box 2: "Haiti, UUSC Project."

117. Ibid.

118. UUSC, "Proposal for a Two-Week Workshop" (no date), 3, GSFR, box 16: "UUSC, Workshop on Family Planning, Haiti, 1975-1977," 717. 
Bordes was ecstatic. He immediately printed new stationary that proudly stated, "Centre d'Hygiène Familiale, recognized by the government for its public utility." ${ }^{119}$ Steckel was happy, too. The clinic in Fond Parisien was now the national model, he exclaimed, so everyone else's "must be 'adjusted' to match ours!"120

As the Director of the Division d'Hygiène Familiale, Bordes hoped to impart yet another virtue to Haitian women: "civic responsibility." He wanted them to take pride in nation-building. Most peasants, he bewailed, were "unaware of any life beyond the village boundaries" and did not think about the nation as a whole. ${ }^{121}$ Bordes implored the Unitarian Universalists to help the Division promote "civic action." The missionaries doubted that civics was relevant in a nation governed by a dynastic dictatorship. "My sense is Ary is very political," one missionary warned McAward, "but he may be non-partisan and unalarmed by Jean-Claude." ${ }^{122}$ Regardless, the Service Committee promised to lend a hand.

119. Law (7 April 1972), in Le Moniteur (15 April 1972). Also see "Le message du Président," Le Nouvelliste (4 January 1972): 1.

120. Richard Steckel to Ary Bordes (12 January 1970), USCR, series no. 16026, box 12: "Haiti, 1970, No. 2." Also see Steckel to Bordes (14 September 1971), same collection, series no. 16026, box 13: "Haiti, 1970-1971, No. 2."

121. Ary Bordes and UUSC, "Promoting Family Health Care through Civic Action" (1980), USCR, serial no. 16093, box 2: "Haiti, Family Planning, No. 1" and "Haiti, Family Planning, No. 2."

122. Elizabeth Coit to John McAward (3 December 1980), USCR, serial no. 16093, box 4: "Haiti, Refugees, Supplementary Material." 
The Division, however, would need additional resources, so it partnered with USAID. The Agency helped Bordes open 20 clinics like the one in Fond Parisien, complete with contraceptives, vehicles, and employees. ${ }^{123}$

Nevertheless, the new establishments lacked credibility because USAID was hesitant to spend any money on healthcare. ${ }^{124}$ According to the Service Committee, the Agency complained "that dollars invested in the Division d'Hygiène Familiale weren't paying sufficiently back in terms of increased family planning acceptance and reduced crude birth rates." ${ }^{125}$ USAID wanted sterilizations. "There is no valid reason why more physicians... cannot be trained to perform sterilization procedures," it declared. ${ }^{126}$ The operation, however, had already killed two Haitian patients.

Frustrated by USAID, Bordes launched into a tirade about policymakers in Washington who "obsessed over the population explosion." ${ }^{127}$ He was dumbstruck by the Agency's conviction that contraceptives would help women

123. Division d'Hygiène Familiale, "Activites de protection materno-infantile et de planification familiale" (1978), 22, USCR, serial no. 16093, box 1: "Haiti, Family Planning, No. 1."

124. Sam Wishik and Norine Jewell, "Evaluation of the Haitian Family Planning Project" (1978), 22, same location as the previous citation.

125. Elizabeth Coit to John McAward (no date), USCR, serial no. 16093, box 2: "Haiti, Family Planning, No. 2."

126. John Kennedy et al., "Evaluation of the Division of Family Hygiene's MCH/FP Program" (1979), 4-5, 82, 92, USCR, serial no. 16093, box 4: "Haiti, Refugees, Miscellaneous."

127. Bordes, Un médecin raconte, 227-29. 
who lacked basic healthcare. McAward had explicitly warned Bordes that USAID would try to impose its own ideas on Haiti. ${ }^{128}$ Bordes' vision, however, had outgrown the Service Committee. The Division needed the Agency's support. "[Dependency] was the Haitian government's philosophy for action," Bordes despaired. Everyone believed that "without the United States, no program was possible because the nation had no money." Every day, "the government sank deeper into this mess," and now "its hands were tied." 129

The Division d'Hygiène Familiale was unable to build the just society that Bordes desired. Nevertheless, the utopian impulse was not inconsequential. The CHF had introduced a vaccine that nearly eradicated tetanus in Fond Parisien, and more than 700 women took birth control, which likely contributed to the decline in the town's population growth rate from 2.4 percent in 1966 to 1.4 percent by $1975 .{ }^{130}$ Needless to say, however, the prototype did not present the world with a "third way" to prosperity. Fond Parisien is still impoverished, and Benin, where Bordes helped the Unitarian Universalists open a clinic, has yet to become a wealthy nation.

The story of the CHF is nonetheless important. It demonstrates how a Haitian technician navigated the Global Cold War to propose his own vision and

128. John McAward to Ary Bordes (20 September 1974), USCR, serial no. 16093, box 2: "Haiti, General, 1974-1977."

129. Bordes, Un médecin raconte, 245.

130. Bordes and Couture, 286-91. 
implement a plan that had a concrete impact on people's everyday lives. At the same time, it exposes how local technicians struggled to overcome the political, economic, and ideological structures that oppress the Haitian people. Ary Bordes and the Unitarian Universalists combined Western medicine and contraception to liberate the nation and its mothers. In the end, however, they perpetuated an unequal division of labor between men and women and were unable to solve Haiti's dependency on the US. 
URBAN PLANNING IN AND OUTSIDE PORT-AU-PRINCE

Earth, left silent by the wind of night, seems shrunken neath the gray unmeasured height.

- William Morris, The Earthly Paradise (1870)

In April 1961, a representative of the United States Operations Mission, Earl Finnie, welcomed a USG technician named Robert Dodge to Haiti. Employed by the Housing and Home Finance Agency (HHFA) in Washington, D.C., Dodge was an expert on urban planning and was asked to assess the slums in Port-au-Prince. The capital, it seemed, was overwhelmed by impoverished migrants, who built wretched shacks throughout the city. Formerly peasants, the migrants might have stayed in the countryside had the Organisation de Développement de la Vallée de l'Artibonite achieved its objectives. As we have seen, however, the Organisation was a lost cause. In response to Finnie's request, Dodge toured the Haitian capital, which was in worse shape than he imagined. "A short drive around the city," he explained, "provides convincing evidence that the housing problem... is critical."1 Even the "low-middle and middle income dwellings are deplorable. Decay and

1. J. Robert Dodge to Earl Finnie (20 April 1961), OMUF, box 28: "Housing," 2843148. 
disrepair are evident everywhere!" He shook his head. "If the present trend is allowed to continue," he warned, "the chances are good that the city proper will become one vast slum in the very near future." Dodge advised Point IV to act quickly. "Such areas," he claimed, "are usually breeders of disease," political unrest, and communism. ${ }^{2}$ This was "an excellent opportunity to provide some type of assistance in the housing and related fields that would touch the lives of these people and demonstrate in a concrete way that... the United States [is] interested in their welfare."

While USOM contemplated an intervention, the United Nations and the Haitian government sponsored a "Master Plan" to address the problems noted by Dodge. Both UN administrators and the Duvaliers envisioned an urban modernity in which everyone would enjoy a minimum standard of living. They admired the "Great Society," President Lyndon B. Johnson's initiative to wipe out poverty in the US. ${ }^{3}$ Like Johnson, the UN insisted that a minimum standard of living was a "human right," and while the Duvaliers generally ignored human rights, they believed it was the government's responsibility to promote material happiness. The Duvaliers employed a paternalistic discourse to legitimize dynastic

2. Ibid.

3. As explained by Gareth Davies in From Opportunity to Entitlement: The Transformation and Decline of Great Society Liberalism (Lawrence: University of Kansas Press, 1996), the Great Society treated the standard of living as both a "civil right" and an "entitlement." Also see John A. Andrew III, Lyndon Johnson and the Great Society (Chicago: Ivan R. Dee, 1999); Sidney M. Milkis, The Great Society and the High Tide of Liberalism (Amherst: University of Massachusetts Press, 2005). 
authoritarianism. Hence, there was an expectation, made explicit by a system of patronage, that the president would try to solve Haiti's worst problems.

In 1972, the UN and the Haitian government employed European specialists, local city planners, and US contractors to devise and implement the Master Plan. The technicians, however, were independent thinkers, who envisioned an alternative modernity. They debated the standard of living, contested modern aesthetics, and dabbled in conservation. While the Duvaliers wanted to improve living conditions in Port-au-Prince, the technicians wished to develop the provinces so they could accommodate the capital's "excess" population. Without anyone's permission, they came up with a new plan that would transform provincial settlements into garden cities, governed by local cooperatives.

The technicians proposed situationally transcendent ideas. Nevertheless, they had to work within a reality governed by political structures. The Duvaliers already had a utopian vision, and they loathed the concept of political decentralization. Likewise, the UN believed the technicians were too ambitious. Administrators insisted they concentrate on the shantytowns in Port-au-Prince, where the standard of living was abysmal. Funded by the UN and the Haitian government, the technicians had to comply with the policymakers' demands. However, they discovered ways to incorporate alternative ideas about modernity into their Master Plan. Guided by the utopian impulse, they organized cooperatives, promoted conservation, and had a relatively positive impact on the community. 
In his multivolume work, The Principle of Hope, Ernst Bloch surveys how the utopian impulse has inspired urban planning throughout history. Ancient and Medieval civilizations, he explains, tried to imitate the "cosmic orders" in nearly everything they built. "The crystal symmetry of the Egyptian pyramid or conversely the hierarchically ordered vitality of the Gothic cathedral" were "architectural metaphors" that established harmony between humanity and the heavens. ${ }^{4}$ What constituted the cité céleste, however, was constantly contested by architects and urban planners. According to Peter Hall, the debate was a "tangled skein." Nevertheless, Hall outlines a modern, "authoritarian" tradition, in which planners tried to systematize, standardize, and control the city. He also delineates an alternative, "anarchist" approach that advocated a "society based on voluntary cooperation among men and women, working and living in small self-governing commonwealths."

The historiography on technocracy maintains that urban planning became increasingly authoritarian in the Cold War era. Historians like Samuel Zipp emphasize how the US and the USSR competed to build the most orderly city. In

4. Bloch, The Principle of Hope, vol. 2, 716.

5. Peter Hall, Cities of Tomorrow: An Intellectual History of Urban Planning and Design in the Twentieth Century (Oxford: Blackwell, 2002, originally published in 1988), 3-4. Robert Fishman examines both authoritarianism and anarchism in Urban Utopias in the Twentieth Century: Ebenezer Howard, Frank Lloyd Wright, and Le Corbusier (New York: Basic Books, 1977). Also see Malcolm Miles, Urban Utopias: The Built and Social Architectures of Alternative Settlements (New York: Routledge, 2008); Amir Ganjavie, "The Role of Utopian Projects in Urban Design," Utopian Studies 25, no. 1 (2014): 125-49. 
the US, Zipp explains, "modern building projects" became "a symbol of American power," as technicians designed "world class cities" that became "the capital of international modernity." Those same technicians evicted impoverished communities and bulldozed low-income housing to create new urban landscapes. ${ }^{7}$ The "Urban Renewal Movement," as it was called, developed a "clean" and "simple" aesthetic that was promoted throughout the world. As noted by Greg Barnhisel in Cold War Modernists (2015), "modernism was a weapon" used in "the struggle for cultural prestige and influence between the communist Soviet Union [and] the United States."

In Haiti, however, many technicians questioned the philosophy behind the Urban Renewal Movement. Nearly every specialist opposed "slum clearing," a strategy commonly applied by modernists. Tasked with the worst slum in Port-au-

6. Samuel Zipp, Manhattan Projects: The Rise and Fall of Urban Renewal in Cold War New York (New York: Oxford University Press, 2010), 5.

7. Christopher Klemek analyzes the Urban Renewal Movement in The Transatlantic Collapse of Urban Renewal: Postwar Urbanism from New York to Berlin (Chicago: University of Chicago Press, 2011). Also see Francesca Russello Ammon, Bulldozer: Demolition and Clearance of Postwar Landscape (New Haven: Yale University Press, 2016); Edward G. Goetz, New Deal Ruins: Race, Economic Justice, and Public Housing Policy (Ithaca: Cornell University Press, 2013).

8. Greg Barnhisel, Cold War Modernism: Art, Literature, and American Cultural Diplomacy (New York: Columbia University Press, 2015), 2-3. Also see Kate Brown, Plutopia: Nuclear Families, Atomic Cities, and the Great Soviet and American Plutonium Disasters (New York: Oxford University Press, 2015); Michael L. Krenn, Fall-Out Shelters for the Human Spirit: American Art and the Cold War (Chapel Hill: University of North Carolina Press, 2005); Roland Vegso, The Naked Communist: Cold War Modernism and the Politics of Popular Culture (New York: Fordham University Press, 2012). 
Prince, they wished to avoid unnecessary destruction, so they renovated what the community had already built. They organized a cooperative and made modest improvements that had a measurable impact on people's everyday lives.

Meanwhile, the technicians' vision to build garden cities in the countryside complicates the common assumption that planners only cared about Port-auPrince. ${ }^{9}$ It also exposes an "anarchist" approach to urban planning that has been overlooked in the historiography on Haiti. Georges Corvington and Georges Eddy Lucien analyze how technicians designed impressive monuments, wide boulevards, and elaborate plazas to demonstrate Haitian modernity. ${ }^{10} \mathrm{Few}$ scholars, however, investigate how they disobeyed the government to promote alternatives to "modernization." Hence, we shall proceed.

\section{Great Societies}

The Master Plan for Port-au-Prince was originally inspired by a consensus between governments that a minimum standard of living was a humanitarian and

9. Historians usually emphasize what Uli Locher describes as "urban bias." In his essay, "Urban Bias in Haiti," Journal of Haitian Studies 2, no. 1 (Spring 1996): 88, Locher explains how "urban bias in Haiti largely overlaps with capital city bias," which extends well beyond urban planning. "All large employers [in Haiti] are urban," and "most operate in Port-au-Prince." The capital is home to most "banks, hospitals, institutions of higher education, and so on."

10. Georges Corvington, Port-au-Prince au cours des ans, 7 vols. (Port-auPrince: Henri Deschamps, 1972-1991); Georges Eddy Lucien, Une modernisation manquée: Port-au-Prince, 1915-1956, 2 vols. (Port-au-Prince: Editions de l'Université d'Etat d'Haïti, 2013). 
political necessity. The "standard of living" entered international discourse in 1941, when Franklin Roosevelt and Winston Churchill signed the Atlantic Charter. As explained by Elizabeth Borgwardt in A New Deal for the World (2005), the charter outlined a new world in which "all the men in all the lands may live out their lives in freedom from fear and want."11

The UN incorporated this idea into its Declaration of Human Rights, which Haiti voted to approve in 1948. Produced by a commission that included the US, the USSR, Britain, France, Yugoslavia, and several Latin American and newly independent nations, the declaration implored everyone to respect "the dignity and worth of the human person" and promote "social progress and better standards of life." ${ }^{12}$ It combined values that we normally associate with the American Revolution, the French Revolution, the Russian Revolution, and the Haitian Revolution, which partially inspired Article 4, that "no one shall be held in slavery." ${ }^{13}$

11. Elizabeth Borgwardt, $A$ New Deal for the World: America's Vision for Human Rights (Cambridge: Belknap Press, 2005), 3-5.

12. "The Universal Declaration of Human Rights," in The Oxford Handbook on the United Nations, eds. Thomas G. Weiss and Sam Daws (New York: Oxford University Press, 2007), 767-71.

13. Samuel Moyn, The Last Utopia: Human Rights in History (Cambridge: Belknap Press, 2010). Also see Charles R. Beitz, The Idea of Human Rights (New York: Oxford University Press, 2009); Lynn Hunt, Inventing Human Rights: A History (New York: W.W. Norton \& Company, 2007); Paul Gordon Lauren, The Evolution of International Human Rights: Visions Seen (Philadelphia: University of Pennsylvania Press, 1998). 
Article 25 of the Declaration of Human Rights states that "everyone has the right to a standard of living" that includes "housing" that is "adequate," but this was hardly the case in Port-au-Prince. In 1947, 197 Haitian technicians founded an independent organization, the Association des Ingenieurs et Architectes Haïtiens, which bemoaned the capital's poverty and uncontrolled expansion. ${ }^{14}$ In its semi-annual periodical, the group explained how the city had "monopolized the majority of commercial activity," in part thanks to "a regime of excessive centralization" instituted by the US occupation. ${ }^{15}$ Provincials migrated to the capital, where "the increase in construction had not kept up with the increase in population." Very noticeable, even back then, were "les taudis," the slums. There were at least 5,000 hovels, the group noted, "with a population between 30,000 and 60,000 living in the most revolting promiscuity."

Despite substandard living conditions in cities like Port-au-Prince, the UN was slow to invoke Article 25, partially due to Washington's ambivalence. The possibility that an international body would intervene in a US city to address issues like racial segregation made Roosevelt's successors uneasy. ${ }^{16}$

14. "Charte de l'Association des Ingenieurs et Architectes Haïtiens" (1947), New York Public Library, Stephen A. Schwarzman Library, Art and Architecture Collection, New York, New York.

15. Jacques Pereira and Jules Blanchet, "Le problème du logement à Port-auPrince," Revue de l'Association des Ingenieurs et Architectes Haïtiens 1, no. 2 (Aug. 1947): 39-44, Avery Architectural and Fine Arts Library, Rare Book Collection, Columbia University, New York, New York.

16. Carol Anderson makes this point in Eyes Off the Prize: The United Nations and the African American Struggle for Human Rights, 1944-1955 (New York: Cambridge University Press, 2003). 
Washington was thus content to overlook Article 25 until new nations, hamstrung by industrialization and urban expansion, demanded that the UN take action. ${ }^{17}$ In 1951, the UN Bureau of Social Affairs instituted a new branch on "Housing, Building, and Planning," but it employed only nine technicians and had no presence in Haiti. ${ }^{18}$

As conditions in Port-au-Prince worsened, many residents thought the government had abandoned them. In his novel, Compère Général Soleil (1955), Jacques Stephan Alexis, a middle class intellectual, portrayed the city as a vile "Port-aux-Crimes" that had devolved into lechery and deprivation. It was a "beautiful whore," he declared, laden with "tempting bits of fool's gold, like a girl sleeping with her legs spread." ${ }^{\text {"19 }}$ A devout Marxist, Alexis blamed the city's demise on the Haitian elite. Because of them, the only obtainable home in his novel was a sorry shack. "Crooked, stinking, and as full of holes as an old basket," the hovel "looked like a wire-covered cage of a chicken house."

François Duvalier promised to improve the standard of living. He envisioned "education, economic, and moral reforms" that would "bridge the gap

17. As explained by Mark Mazower in No Enchanted Palace: The End of Empire and the Ideological Origins of the United Nations (Princeton: Princeton University Press, 2009), the US government wanted the UN to protect nationstates, not individual people.

18. Charles Abrams, Man's Struggle for Shelter in an Urbanizing World (Cambridge: MIT Press, 1964), 91-92.

19. Jacques Stephan Alexis, General Sun, My Brother (originally published in 1955), trans. Carrol F. Coates (Charlottesville: University Press of Virginia, 1999), 5-9. 
between the elite and the masses." ${ }^{20}$ Toward this end, he beseeched the "working classes" and sympathetic "elites of the middle class," such as Alexis, to mobilize behind a black president, who would implement "totalitarian humanism" and build a "social republic." ${ }^{21}$ As Président à Vie, Duvalier pledged to take "all the social classes into his care."22 When Alexis questioned the president's sincerity, however, he was chased into exile. Upon return in 1961, he was arrested and presumably killed.

As the Duvaliers vowed to improve the standard of living, Cold Warriors, like Charles Abrams, entreated policymakers in Europe and the US to lend a hand. A renowned urbanist, Abrams warned that Soviet technicians were already "supplying building materials, construction machinery, and engineering equipment to a number of countries. ${ }^{" 23} \mathrm{He}$ urged the West to educate loyal

20. Lorimer Denis and François Duvalier, Problème des classes à travers l'histoire d'Haïti (Port-au-Prince: Imp. de l'Etat, 1958, originally published in 1948), 88-89.

21. In his essay, "Pour un humanisme totalitaire," Les Griots: la revue scientifique et littéraire d'Haïti 4, no. 1 (Apr.-Sept. 1939), François Duvalier proclaimed that "humanism positively states the dignity of the human person." It includes the "endeavors of man's conscience" to "raise [humanity] to the universal." By contrast, "totalitarian humanism" assumes "the fundamental unity of human nature," while acknowledging "peculiarities" that may necessitate an alternative to democracy.

22. This was inscribed in the Constitution de la République d'Haïti (Port-auPrince: Imp. de l'Etat, 1964), section 14, articles 196 and 197.

23. Charles Abrams, Housing in the Modern World (London: Faber \& Faber, 1964), 242-50, 287. 
technicians in nonaligned nations to counterbalance Soviet aid. ${ }^{24}$ In 1954, Abrams helped the UN create Middle East Technical University in Turkey ${ }^{25}$ Meanwhile, colleges in Western Europe invited Turkish students to come study urban planning. One student, Tarik Carim, would go on to serve the UN in Haiti.

By 1959, the US government, like Abrams, believed that the best way to contain communism was to improve the standard of living. In July of that year, Vice President Richard Nixon and Soviet First Secretary Nikita Khrushchev toured the American National Exhibition in Moscow, where they observed America's newest household appliances and debated how to maximize consumption. ${ }^{26}$ Nixon hoped that washing machines and electric stoves would exert "soft power" and convince nonaligned nations to ally with the US. ${ }^{27}$

The so-called "Kitchen Debate" between Nixon and Khrushchev quickly made its way to Haiti, where USOM introduced a "modern" washing machine in 1959. Since electricity was unavailable in the countryside, the machine was

24. A. Scott Henderson, "The Cold War, the United Nations, and Technical Assistance," in Housing and the Democratic ldeal: The Life and Thought of Charles Abrams (New York: Columbia University Press, 2000).

25. Burak Erdim, "Middle East Technical University and Revolution: Development Planning and Architectural Education During the Cold War, 19501962" (Ph.D. Dissertation: University of Virginia, 2012).

26. Jack Masey and Conway Lloyd Morgan analyze the "Kitchen Debate" in Cold War Confrontations: US Exhibitions and Their Role in the Cultural Cold War (Baden: Lars Müller Publishers, 2008). Also see Ruth Oldenziel and Karin Zachmann, Cold War Kitchen: Americanization, Technology, and European Users (Cambridge: MIT Press, 2009).

27. Greg Castillo, Cold War on the Home Front: The Soft Power of Midcentury Design (Minneapolis: University of Minnesota Press, 2010), 3-4. 


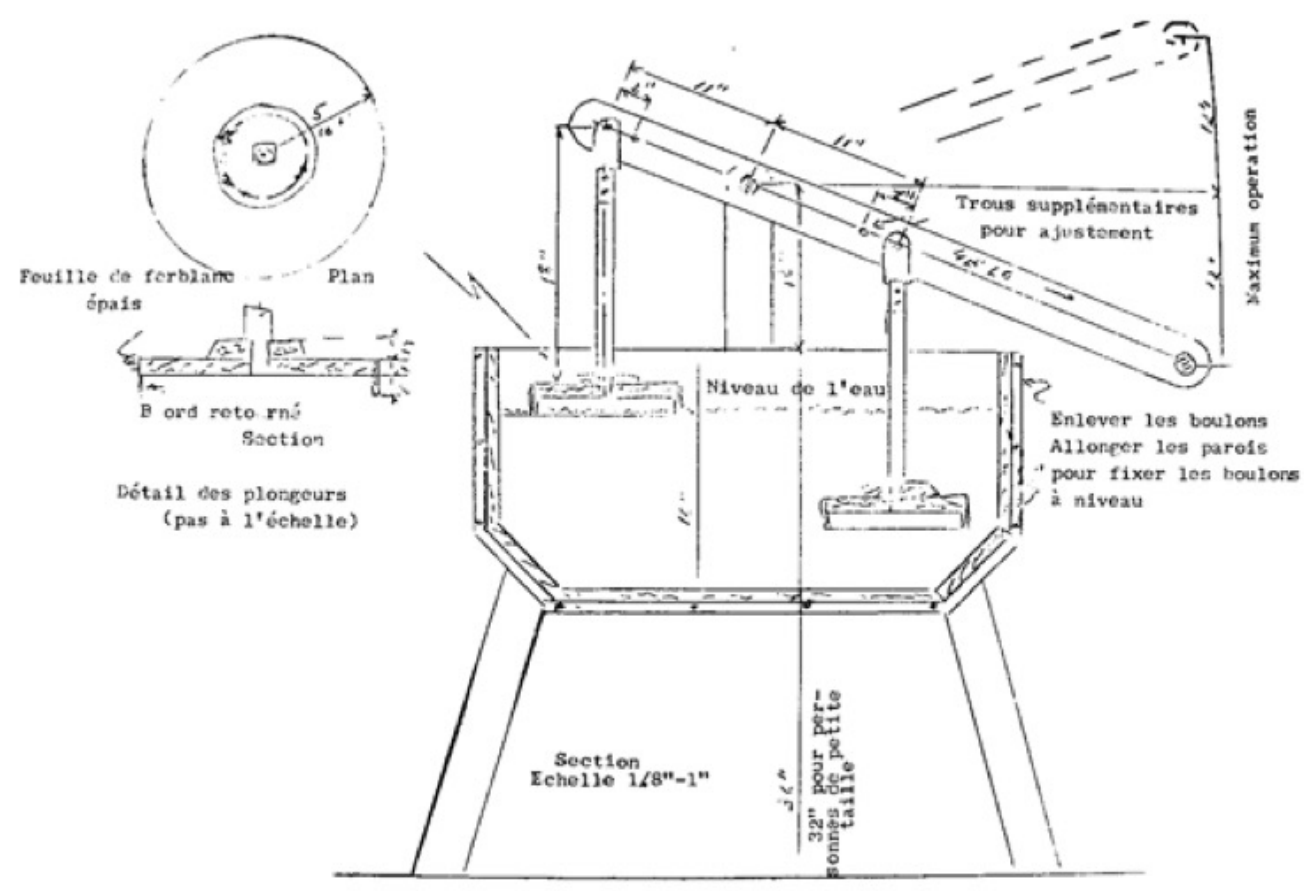

Fig. 15 Blueprint for Washing Machines in Haiti. From: Service Coopératif Haïtiano-Americain d'Education Rurale, "La lessive chez soi" (1959), United States Operations Mission to Haiti, Unclassified Central Subject Files, 19481962, box 15: "Commodities: Washing Machines," 4480972. Records of the United States Foreign Assistance Agencies, 1942-1963, Record Group 469, Entry No. 262, National Archives in College Park, Maryland.

specially designed to use a hand crank (Fig. 15). USG technician Harry Yoe happily reported that "the hand-made, hand-operated wooden machine aroused so much interest among people both urban and rural that it is being copied in each department of the country." 28 USOM even dispatched specialists to "demonstrate the machine at any time and place."

While Nixon touted the wonders of the capitalist world-economy, social scientists, like Oscar Lewis, argued that government intervention was necessary

28. Harry Yoe to Robert Burns (26 February 1959), OMUF, box 15 :

"Commodities: Washing Machines," 4480972. 
to improve the standard of living. An anthropologist at the University of Illinois, Lewis studied the vecindades, slum-like settlements in Mexico City. He believed they had "distinctive social and psychological [qualities]" that imprisoned them in a "culture of poverty." According to sociologist Michael Harrington, "only the larger society, with its [collective] resources," can help them "break out."30

Like a prophet, Harrington heralded a "massive assault upon the entire culture of poverty in American society." In 1964, President Lyndon Johnson instituted the Office of Economic Opportunity (OEO) to carry out a "War on Poverty" and create a "Great Society." "We will have to build [new] homes," he proclaimed. "We must rebuild the entire urban United States!" ${ }^{22}$ Toward this end, Congress passed the Housing Act of 1965, which promoted a holistic approach

29. Oscar Lewis, Five Families: Mexican Case Studies in the Culture of Poverty (New York: Basic Books, 1975, originally published in 1959), 2. Lewis revived a missionary ideology that dated back to the early twentieth century, when settlement houses tried to uproot prostitution and alcoholism in minority communities. Paul Boyer analyzes this ideology in Urban Masses and Moral Order in America, 1820-1920 (Cambridge: Harvard University Press, 1978). Also see Roy Lubove, The Professional Altruist: The Emergence of Social Work as a Career, 1880-1910 (Cambridge: Harvard University Press, 1965) and The Progressives and the Slums (Pittsburgh: University of Pittsburgh Press, 1962).

30. Michael Harrington, The Other America: Poverty in the United States (New York: Touchstone, 1997, originally published in 1962), 15.

31. James T. Patterson, America's Struggle Against Poverty in the Twentieth Century (Cambridge: Harvard University Press, 2005, originally published in 1994), 122-49.

32. Lyndon B. Johnson, "Remarks at the University of Michigan" (22 May 1964), in The Public Papers of the Presidents of the United States: Lyndon B. Johnson, 1963-64, vol. 1 (Washington, D.C.: Government Printing Office, 1964), 704-7. 
to urban rehabilitation—what was, in essence, "master planning." ${ }^{33}$ Congress also transformed the HHFA into the Department of Housing and Urban Development (HUD), which introduced a new initiative to build "Model Cities" throughout the US.

The UN, meanwhile, organized a new Center for Housing, Building, and Planning (CHBP) and recruited Johnson's lieutenants, the so-called "Poverty Warriors," to execute its objectives. One such recruit, Anthony Radspieler, was dispatched to Haiti. The UN noted Radspieler's involvement with the Regional Economic Development Commissions created by the Public Works Act of 1965 and thought he was the best candidate to help the inhabitants of Port-auPrince..$^{34}$ "One of the rewarding and satisfying aspects of your mission," it told him, "is that which derives from fruitful contact with the people of the host country." 35

While the CHBP enlisted his "Poverty Warriors," Johnson turned to private contractors, like the Foundation for Cooperative Housing $(\mathrm{FCH})$, to continue the War on Poverty. Founded in 1952 by the architect, Clarence Stein, and his

33. Roger Biles, The Fate of Cities: Urban America and the Federal Government, 1945-2000 (Lawrence: University Press of Kansas, 2011), 112-59.

34. Anthony Radspieler, Resume, enclosed in a Memo (22 March 1973), United Nations Archives (UNAR), New York, New York. Registry No. TE 322/1, S-01750550-05: "Technical Assistance Mission in Haiti: Physical, Regional, and Urban Planning, 240-1, Part 3."

35. Abdulrahim A. Farah to Anthony Radspieler (24 August 1973), UNAR, Registry No. TE 322/1, S-0175-0550-05: "Technical Assistance Mission in Haiti: Physical, Regional, and Urban Planning, 240-1, Part 3." 
protégé, Roger Willcox, FCH was a non-profit corporation that organized housing cooperatives in middle-to-low income communities. The company ballooned in size when it embraced the HUD's mission to accommodate low income, elderly, and African-American populations. ${ }^{36}$

FCH would also carry the War on Poverty overseas. ${ }^{37}$ In March 1965, the same month that Lyndon Johnson delivered a special address on urban development, FCH instituted a wholly owned subsidiary, FCH International, Inc. $(\mathrm{FCHI})$, to help USAID promote "Great Societies" throughout Latin America. ${ }^{38}$ FCHI employed former CHBP, USAID, and HHFA technicians, including Robert Dodge, who had visited Haiti back in 1961 (Fig. 16). It also participated in international workshops co-hosted by USAID and the HUD. ${ }^{39}$

36. "FCH Company Regional Offices Now Serve Most Parts of the USA," FCH News Briefs 3, no. 3 (Mar. 1966): 1-2. Also see FCH, "Housing Is for People" (1982), 12-20, Foundation for Cooperative Housing Records (FCHR), Global Communities, Silver Spring, Maryland.

37. Impressed by the National Cooperative Business Association and the National Credit Union Administration's work outside the US, Minnesota Senator Hubert Humphrey proposed a new amendment to the 1961 Foreign Assistance Act that would promote cooperatives. "Community action," Humphrey argued, was the best way to "increase the standard of living" and cultivate "democra[cy]." USAID, "Implementation of the Humphrey Amendment," presentation to the US Senate, 87th Congress, 2nd session (Washington, D.C.: Government Printing Office, 1962), 3 .

38. "FCH Sets Up International Subsidiary," FCH News Briefs 2, no. 3 (Mar. 1965): 3.

39. "Two Housing Workshops Planned by HUD International Division" FCH News Briefs 3, no. 6 (Jun. 1966): 6. 


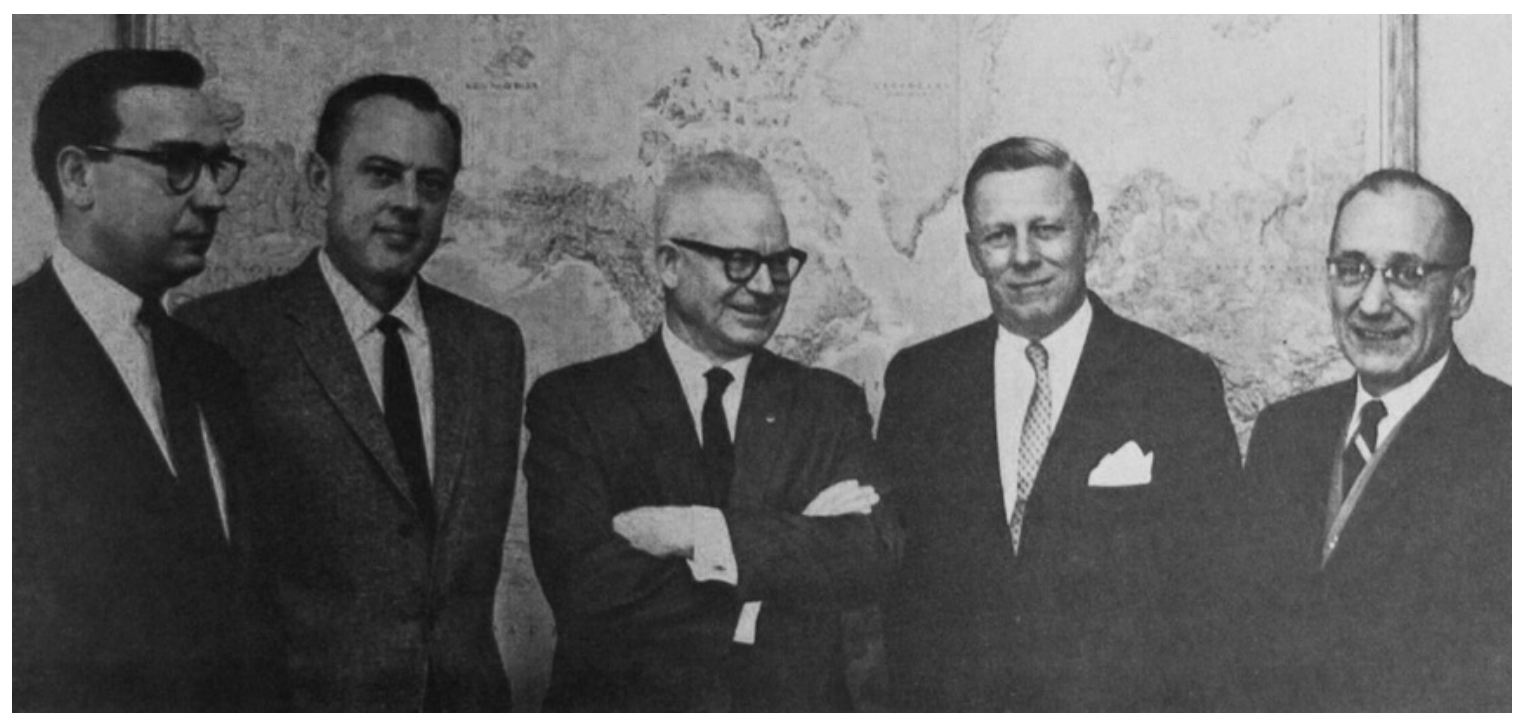

Fig. 16 Wallace Campbell (middle), President of the Foundation for Cooperative Housing International, Inc. with Robert Dodge (second from the right) and Jack Edmondson (far left). From: FCH News Briefs 3, no. 2 (Feb. 1966): 1. Foundation for Cooperative Housing Records, Global Communities, Silver Spring, Maryland. Reproduced with permission.

Planning and Development Collaborative International (PADCO) was another company built mostly upon USAID money. Founded in 1965 by sociologist Alfred Van Huyck, PADCO was headquartered outside Washington and employed both US and European technicians. Between 1965 and 1980, PADCO received 45 USAID contracts: 15 in Asia, 13 in Latin America, 11 in Africa, and 6 in the Middle East. ${ }^{40}$ PADCO helped the Agency assess surveys in Chile, and it supported post-earthquake reconstruction in Guatemala. The company had only 8 UN contracts when it was summoned to Haiti in 1973. While PADCO and FCHI were mostly apolitical, USAID was overtly anticommunist. It employed the two companies to improve the standard of living

40. PADCO, Report entitled, "PADCO" (June 1988), 7-13. 
in nations threatened by communist revolution. Between 1961 and 1967, USAID administered the "Alliance for Progress" in Latin America. It distributed 20 billion US dollars to "build a hemisphere where all men can hope for a suitable standard of living and all can live out their lives in dignity and in freedom." ${ }^{41}$ This money, however, also served to immunize the region against communism. ${ }^{42}$ Dispatched by USAID to nine Latin American nations, FCHI noted how "the Alliance for Progress is working in the field of cooperative housing is because [it] considers its program for peace will be helped if more people in Latin America had a strong economic stake in their country." According to $\mathrm{FCHI}$, "the Alliance thought that people with a strong economic stake would fight to defend democracy and resist communism."43

USAID was not the only one waging a war on poverty in Latin America. In 1970, James W. Trowbridge, a philanthropist employed by the Ford Foundation, visited the Université d'Etat d'Haïti to meet the Professor of Sociology, Hubert de

41. John F. Kennedy, Address (13 March 1961), in The Department of State Bulletin 44, no. 1136 (3 April 1961): 471-74.

42. Kennedy created USAID by executive order to implement the Foreign Assistance Act passed by Congress in 1961. In part two, section 501, the act explicitly stated that it was "the intention of the Congress" to apply aid money to improve "the ability of friendly countries and international organizations to deter or, if necessary, defeat communist or communist-supported aggression."

43. FCHI and USAID, Cooperative Housing Training Institute, "Legal Aspects of Cooperative Housing," (Washington, D.C.: FCHI, 1963), 14, Avery Architectural and Fine Arts Library, Rare Books Division, my own emphasis. Also see "FCH President Notes Encouraging Co-op Housing Programs in Latin America," FCH News Briefs 2, no. 12 (Dec. 1965): 1-3. 
Ronceray. ${ }^{44} \mathrm{~A}$ "structural functionist," Ronceray analyzed "psycho-sociological" problems in Port-au-Prince. ${ }^{45}$ Aided by Trowbridge, he produced a study on ruralurban migration, claiming that migrants had abandoned the peasantry to join "modernity." ${ }^{46}$ Roughly 48 percent of migrants, however, were illiterate, and 38 percent were unemployed. As a result, they were trapped in "marginality," between "modernity" and "tradition," said Ronceray. ${ }^{47}$

Ronceray believed the situation in Port-au-Prince was deteriorating. Nevertheless, Jean-Claude Duvalier continued to bellow the government's paternalistic rhetoric when he succeeded his father as president. On 22 April 1972, he pledged to "provide in each home... a minimum state of well being compatible with the human condition of the late twentieth century." ${ }^{48}$ He vowed to

44. As explained by Inderjeet Parmar in Foundations of the American Century: The Ford, Carnegie, and Rockefeller Foundations and the Rise of American Power (New York: Columbia University Press, 2012), the Ford Foundation was created in 1936 by the President of the Ford Motor Company, Edsel Ford, to promote "human welfare" around the world.

45. Hubert de Ronceray, "Enquête sur le processus d'urbanisation à Port-auPrince" and "La création du CHISS," Les cahiers du CHISS: revue haitienne de sciences sociales 8, no. 11 (Oct. 1974): 3-12, 28. Like the renowned sociologist, Talcott Parsons, Ronceray interpreted society as a system, governed by traditions, values, and expectations.

46. Centre Haïtien d'Investigation en Sciences Sociales (CHISS), "Les valeurs culturelles du migrant," in "Le processus d'urbanisation à Port-au-Prince" (1974), 122-23. Also see Hubert de Ronceray, Sociologie du fait haïtien (Québec: Presses de l'Université de Québec, 1979); "Savoir pour prévoir, prévoir pour agir," Le Nouvelliste (30 January 1970): 1.

47. CHISS, "Le processus d'urbanisation à Port-au-Prince," 119-25.

48. Jean-Claude Duvalier, Address (22 April 1972), in Discours et messages, vol. 1 (Port-au-Prince: Henri Deschamps, 1978), 209-24. 
address the "severe housing crisis" in Port-au-Prince and "rebuild the city, to make it beautiful and prosperous." Consequently, his name evoked anticipation. ${ }^{49}$ "Jean-Claudisme" was "the struggle against les taudis, hunger, and misery." 50

Ronceray warned Jean-Claude not to make empty promises. "The Duvalierist Revolution," he explained, "was now permanently associated with the socio-economic promotion of the masses." 51 There were "growing expectations," but the government was "poorly equipped" to meet them. "The need for housing exceeded the economy's capabilities," Ronceray bewailed. ${ }^{52}$ As a result, people lived in "a permanent state of dissatisfaction."

Unable to rebuild Port-au-Prince on his own, Jean-Claude beseeched the UN to assist his government. In response, the UN dispatched a German technician named Paul-Walter Bouda to create a "Master Plan."

When Bouda arrived in 1972, he was shocked by the standard of living in Port-au-Prince..$^{53}$ It was especially bad in the shantytown of St. Martin, where 17,814 people lived in 2,165 homes that were packed into a mere $.05 \mathrm{mi}^{2}$. Nearly

49. Pierre Buteau and Lyonel Trouillot analyze Jean-Claude's rhetoric in Le prix du Jean-Claudisme: arbitraire, parodie, désocializacion (Port-au-Prince: C3 Editions, 2013).

50. "Qu'est-ce que le Jean-Claudisme?" L'Assaut: organe du Jean-Claudisme 1, no. 9 (Sept. 1978): 19-20.

51. "Sociographie d'Haïti," Les cahiers du CHISS 7 no. 10 (Oct. 1973): 55-56.

52. CHISS, "Le processus d'urbanisation à Port-au-Prince," 77-78.

53. Paul-Walter Bouda with Henry-Robert Dubois, "Des chiffres qui font peur," Le Matin (12 March 1974): 1-2. 
65 percent of the population worked in the nearby market—a twelve minute walk to the southwest. ${ }^{54}$ They sold charcoal, clothes, and tobacco, and made between 10 and 40 US dollars a month. ${ }^{55}$ They paid about 8 dollars a month to live in small $10 \mathrm{~m}^{2}$ shacks that had recycled, wooden walls, iron roofs, and dirt floors. "Almost all the [home] owners [in St. Martin] were Macoutes, or if not Macoutes, then affiliated with [Duvalier] in some fashion," explained one technician. ${ }^{56}$ They governed the slum like ward bosses, demanding payment in exchange for "protection."

Distressed by the population density in Port-au-Prince, the UN consulted the Institut Haïti de Statistique, which had conducted a survey on population and housing between 1970 and 1971. The Institut noted how Haiti's urban population had spiked 132.2 percent to 879,708 since $1950 .{ }^{57}$ While the nation's total population had increased by 39 percent (to $4,314,628$ ), the survey revealed how

54. Institut Haïtien de Statistique, "Les logements et les manages" (1981), tables 10 and 11, UNAR, Registry No. TE 322/1, S-0175-1291-02: "Demographic Analysis and Research Unit in Haiti, 260-1, Part 4," enclosed in an envelope.

55. CONADEP and the United Nations Development Programme (UNDP), "Avant projet pour la rehabilitation du quartier St. Martin" (1977), 14-19, UNAR, Registry No. TE 322/1, S-0175-0555-03: "Technical Assistance Mission in Haiti: Institutional Strengthening in Physical and Urban Planning, 240-3, Part 1."

56. Simon M. Fass, Political Economy in Haiti: The Drama of Survival (New Brunswick: Transaction Publishers, 1988), 213.

57. Institut Haïtien de Statistique, "Résultats préliminaires du recensement général la population, du logement et de l'agriculture" (1973), Latin American Documents, film 2351, reel 637, item 7, tables 1-1-1, 1-2-1, 1-3-2, 1-4-1, Robert Manning Strozier Library, Micromaterials Collection, Florida State University, Tallahassee, Florida. 
the peasantry, crippled by soil erosion, had collapsed into Port-au-Prince. Home to only 151,918 people in 1950 , the capital had more than tripled in size to 506,525 . Nowhere was this more visible than downtown. The downtown market "was the most important marketplace in the country," the UN explained. It was extremely crowded, and there was "no responsible management."

The President of the Association des Ingenieurs et Architectes Haïtiens, Harry Tippenhauer, wanted to know what the UN planned to do about it, so he invited Bouda to address the public on "World Urbanism Day," 8 November $1973 .{ }^{59}$ Joined by his two Haitian counterparts, Louis Jadotte and Albert Mangonès—both employed by the Conseil National de Développement de la Planification (CONADEP)—Bouda explained how they intended to compile an "inventory" with "all the problems that have a direct impact on the lives of citizens in the city." ${ }^{60}$ Aided by a Turkish specialist, Tarik Carim, a former "Poverty Warrior," Anthony Radspieler, and two private contractors, FCHI and PADCO,

58. CONADEP and UNDP, "Plan de développement de Port-au-Prince et de sa region métropolitaine, projet d'action immédiates: renovation du centre de la capitale" (no date), UNAR, Registry No. TE 322/1, S-0175-0552-02: "Technical Assistance Mission in Haiti: Physical, Regional, and Urban Planning, 240-1, Part 7, , enclosed in an envelope.

59. Harry Tippenhauer to Paul-Walter Bouda, Louis Jadotte, and Albert Mangonès (26 October 1973), UNAR, Registry No. TE 322/1, S-0175-0550-05: "Technical Assistance Mission in Haiti: Physical, Regional, and Urban Planning, 240-1, Part 3." Also see J.B. Roumain to Paul-Walter Bouda (4 October 1973) and Bouda to Roumain (9 October 1973), same location.

60. "8 Novembre: Jour Mondial de l'Urbanisme," Le Nouveau Monde (8 November 1973): 1 . 
they would try to create "une ville plus humaine." ${ }^{\text {11 }}$ They were assembled to vanquish the "culture of poverty" and uphold a minimum standard of living. Each technician, however, came to the table with a unique vision.

Intellectual Anarchy

In 1973, Paul-Walter Bouda and Tarik Carim met with the Ministre des Travaux Publics, Pierre Petit. Anxious to improve the standard of living, Petit insisted they do away with the bidonvilles in Port-au-Prince. Carim, however, deemed it unnecessary and inhumane. The best way to abolish the slums, he reasoned, was to invest in a secondary city, which could then accommodate migrants who would otherwise settle in the capital. ${ }^{62}$ Petit was reluctant to support a new plan without Duvalier's approval, but he lent Bouda and Carim his best architect, the Directeur de l'Urbanisme, Gérard Hippolyte.

Carim was not the only one who questioned the practice of "slum clearing." As explained by PADCO technician Alfred Van Huyck, "many experts in the housing field in the developing countries, such as John Turner of [MIT] and Charles Abrams of Columbia University, have recognized the futility of

61. Ibid., 8.

62. Tarik Carim, "Mission en Haïti du Conseiler Technique" (10-24 January 1974), 9, UNAR, Registry No. TE 322/1, S-0175-0551-01: "Technical Assistance Mission in Haiti: Physical, Regional, and Urban Planning, 240-1, Part 4." 
conventional housing solutions in developing countries." ${ }^{13}$ In Haiti, meanwhile, the anthropologist, Sidney Mintz, encouraged technicians to reassess the bidonvilles. According to Van Huyck's colleague, Simon Fass, "Mintz presented the image of a highly complex network of relationships and flows that functioned efficiently." ${ }^{14} \mathrm{He}$ "guided us away from early ideas about clearing streets of traders" and "[taught us that] traders were real and normal [people]."

Van Huyck noted a fundamental disagreement between policymakers and technicians. Policy at the top, he explained, was based on the idea that "basic standards in housing" were necessary to combat the "culture of poverty" and promote a "desirable sociological and physical environment necessary for the healthy growth of the individuals in the community." ${ }^{65}$ Most technicians, however, interpreted the "culture of poverty" as a "generalization." Aptly stated by Charles Abrams, they believed it contained "some truth, some half-truth, and some non-

63. Alfred Van Huyck, "The Housing Threshold for Lowest-Income Groups: The Case of India," in Urban Planning in the Developing Countries, eds. John D. Herbert and Alfred Van Huyck (New York: Praeger, 1968), 66. John Turner was previously employed by the CHBP in the Peruvian barriadas. In his report, "Uncontrolled Urban Settlement: Problems and Policies," in The City in Newly Developing Countries, ed. Gerald Breese (Englewood Cliffs: Prentice-Hall, 1969), 508-12, he noted how even the worst slum shacks were "forward-moving vehicles of social and economic change."

64. Fass, Political Economy in Haiti, 102-4. Fass cited Sidney Mintz, "The Employment of Capital by Market Women in Haiti," in Capital Saving and Credit in Peasant Societies, eds. Raymond Firth and Basil S. Yamey (Chicago: Aldine Publishing, 1964).

65. Van Huyck, 65-67. 
truth." ${ }^{66}$ Van Huyck was sympathetic toward both sides but confessed that the "standard of living" was a little ambiguous. Policymakers claim that "these standards cannot be lowered" and "must be adhered to at all costs," he expounded, but they should take into account "the total environment," as well as the circumstances "in which the individual lives." As Turner once proclaimed, "a materially poor house may be better than a materially good one in a given situation." ${ }^{n 7}$

This idea was antithetical to modernism in Haiti. Commonly associated with the City Beautiful Movement, modernism peaked in 1948, when President Dumarsais Estimé built a model city in Belladère ${ }^{68}$ Estimé also employed Albert Mangonès and a Romanian architect, Albert Schmidigen, to design a Cité Exposition that would commemorate the bicentennial anniversary of Port-auPrince. Complete with palm-tree colonnades and statues of Greek nymphs, the Cité, like Washington, D.C., and Soviet Moscow, symbolized national modernity. ${ }^{69}$ It eschewed the ornate complexity that characterizes Haiti's vernacular "gingerbread" houses and upheld a simple, uncluttered, "engineer's

66. Charles Abrams, The City is the Frontier (New York: Harper \& Row, 1965), 26.

67. Turner, 510-11.

68. "Les travaux de Belladère," Revue de l'Association des Ingenieurs et Architectes Haïtiens 1, no. 1 (Jul. 1947): 26-28.

69. Georges Corvington, Port-au-Prince au cours des ans, vol. 7, La ville contemporaine, 1934-1950. Also see Hadassah St. Hubert, "Visions of a Modern Nation: Haiti at the World's Fairs, 1931-1967" (Ph.D. Dissertation: University of Miami, forthcoming). 
aesthetic." ${ }^{70}$ The new Musée des Beaux Arts was so "modern" that Schmidigen drew its likeness in a triangle to emphasize its elegant proportions. ${ }^{71}$ Inside the Musée were paintings by Pablo Picasso, reproduced by the Museum of Modern Art in New York. $^{72}$

For Mangonès, modernism was a means to look beyond the sensory world and explore Haiti's invisible, psychological architecture. ${ }^{73}$ His "Self Portrait" (1945) bares a striking resemblance to the tortured bull in Picasso's "Guernica" (1937). By the mid 1950s, however, his opinion of modernism had changed. The

70. As noted by Le Corbusier in Towards a New Architecture (New York: Dover, 1986, originally published in 1931), "the engineer, inspired by the law of economy and governed by mathematical calculation, puts us in accord with universal law." They "employ geometrical forms, satisfying our eyes by their geometry and our understanding by their mathematics." They "provoke in us architectural emotions and thus make the work of man ring in unison and universal order." By contrast, Michel R. Doret analyzes Haiti's vernacular architecture in Le style gingerbread (Ornex-Maconnex: Editions Amon Râ, 1991). Also see Edward E. Crain, Historic Architecture in the Caribbean Islands (Gainesville: University Press of Florida, 1994); Andrew Gravette, Architectural Heritage of the Caribbean (Princeton: Markus Wiener, 2000).

71. "Musée des Beaux Arts," in Exposition internationale, 1949-1950 (New York: A.F. Schmiedigen Associates, 1949), 19.

72. Georges Henri Rivière, "Rapport sur la reorganisation des musées haïtiens" (1949), Office of the Commissioner to the International Exposition for Founding of Port-au-Prince, Program Records, 1959-1951 (IEPR), box 3: "58-D12: Museum," 3680848. Records of International Conferences, Commissions, and Expositions, 1825-1970, Record Group 43, Entry No. p170, NACP. Haitians embraced the "Demoiselles d'Avignon" (1907), in which Picasso portrayed an African mask, giving people of African descent a new claim to Western modernity.

73. As explained by Pericles Lewis in The Cambridge Introduction to Modernism (New York: Cambridge University Press, 2007), modernism was a movement that experimented with alternative ways to address both new human experiences and new revelations about the mind and the cosmos. 
problem with modernism, he noticed, was that it overlooked the most visible, everyday problems that troubled the Haitian people. ${ }^{74}$ Like the journalist, Jane Jacobs, who challenged the Urban Renewal Movement in New York, Mangonès criticized how modernism had become increasingly "anti-democratic" and "authoritarian." 75

Case in point was Duvalier-Ville, a model city, built by the Haitian government in 1961. Like the Cité Exposition, Duvalier-Ville emphasized symmetry and beauty (Fig. 17). Created to commemorate the presidency of François Duvalier, the city instead became an embarrassment when the British novelist, Graham Greene, exposed how the government had trampled upon the local population. Duvalier, he sneered, must have been "planning for a better class of people. ${ }^{76}$

Similarly, the Directeur de l'Urbanisme, Gérard Hippolyte, questioned the importance of symmetry. While a student at the Institution St. Louis de Gonzague in Port-au-Prince, he discovered a painting with perpendicular lines and primary

74. Albert Mangonès, "Dans la chair et dans le sang" and "Dans la cité vacarme," Reflets d'Haïti 1, nos. 5 and 11 (29 October 1955, 10 December 1955).

75. Albert Mangonès, "La ville que l'on mérite," Reflets d'Haïti 1, no. 4 (22 October 1955). Mangonès eventually became a preservationist. He even socialized with Jacobs' allies in New York, including James Marston Fitch, who gave him advice on how to preserve Citadelle Laferriere. See the correspondence between Mangonès and Fitch (1977-1978), James Marston Fitch Papers (JMFP), box 1: "Haiti," 35. Avery Architectural and Fine Arts Library, Drawings and Archives.

76. Graham Greene, The Comedians (London: Bodley Head, 1966), 342. 


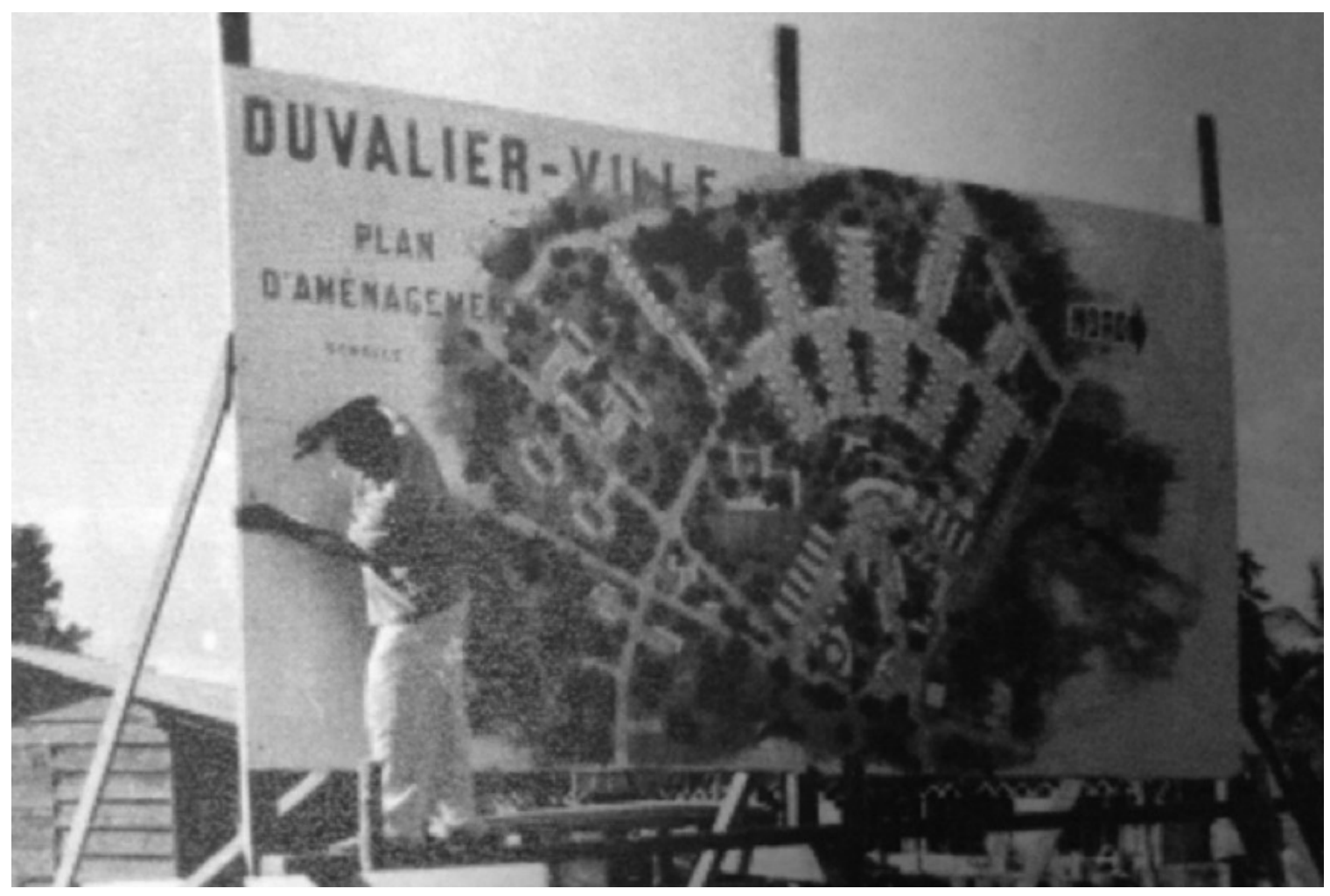

Fig. 17 Plan for Duvalier-Ville (no date). Photo by Bernard Diederich. From: Bernard Diederich Collection, box 15: 3045001. Steven and Dorothea Green Library, Florida International University, Miami, Florida. Reproduced with permission.

colors. "The Frères [de l'instruction] were very rooted in traditional art," he explained, so no one knew what to make of it. "When I found the painting years later," however, "[l learned that] it was [created by the renowned Dutch modernist, Piet] Mondrian.. ${ }^{77}$ Hippolyte admired Mondrian's work but felt imprisoned by its perfectly straight lines. Unlike Mondrian, he liked to paint wildly.

77. Quoted by Gérald Alexis in Hippolyte: Module 30 (Port-au-Prince: Imp. II, 1993), 6. 


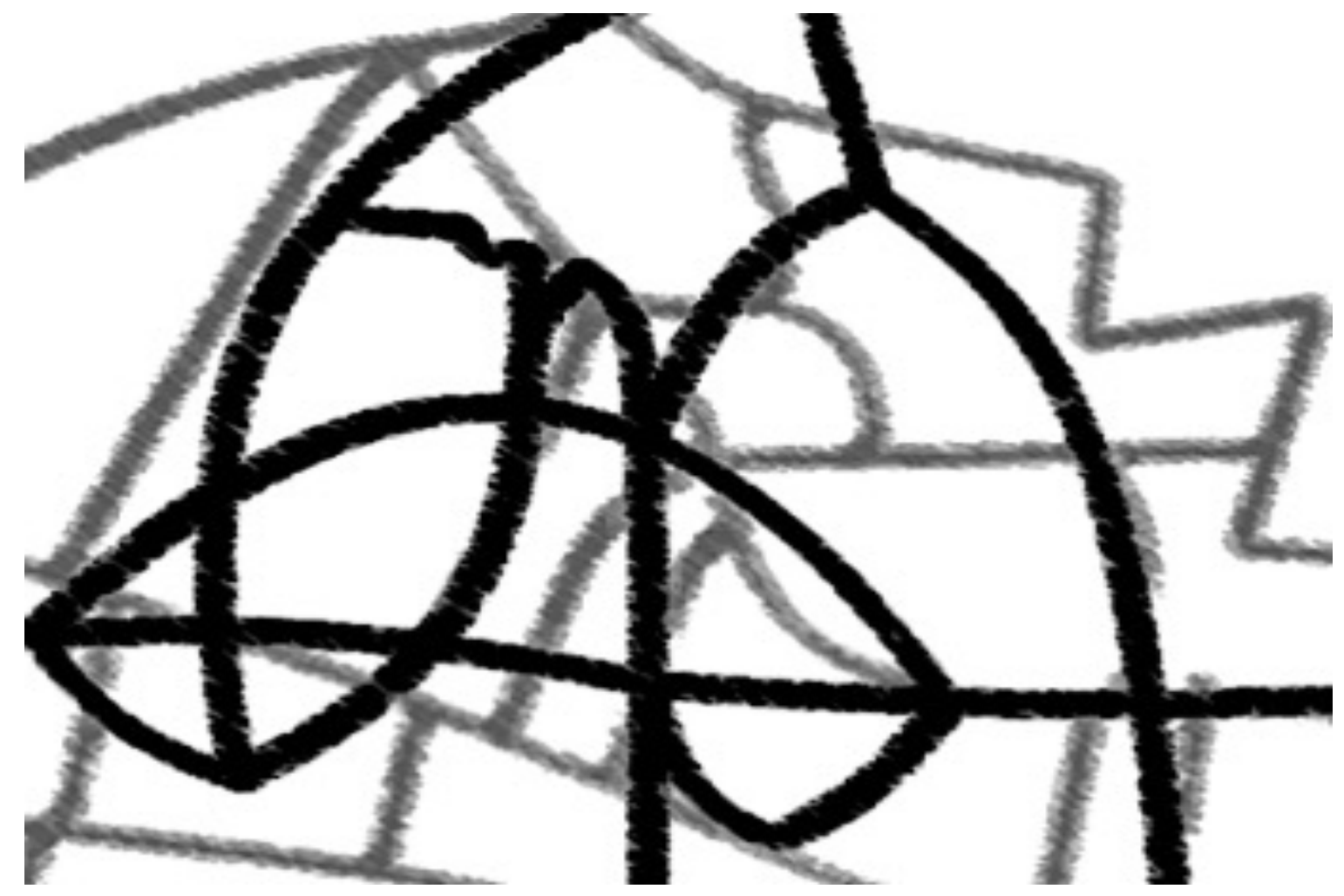

Fig. 18 Art and Urban Planning. A sketch by Adam M. Silvia that superimposes the lines in "Untitled," acrylic on canvas by Gérard Hippolyte (black), on a map of St. Martin (grey), a shantytown that Hippolyte helped renovate.

As both an artist and a technician, he gave little thought to the engineer's aesthetic (Fig. 18).

\section{Garden Cities}

In 1974, the technician, Tarik Carim, departed Port-au-Prince to survey the provinces. In search of a secondary city that could accommodate the country's migrants, he journeyed north, to Cap-Haïtien. Inhabited by 46,200 people, "Okap," as the locals call it, was the nation's second largest city. The 
third largest, Gonaïves, had only 29,261 people. Carim was surprised to learn that six towns and one city, Jacmel, were growing at a slower rate than the nation as a whole. ${ }^{78}$

Carim shared his discovery with Anthony Radspieler, who concluded that migration, in combination with "the stagnation and decline of towns in the interior of the country," had "create[d] a powerful 'push' on the rate of growth of the population in Port-au-Prince. ${ }^{, 79}$ The situation was "dangerous," he warned. Carim agreed. "Given the current structure of Haiti's urban network," he postulated, “there is a legitimate reason to fear that [the population's] distribution has already created a dynamic that will be difficult to reverse. ${ }^{" 80}$ Carim thought Haiti should invest in Cap-Haïtien, which had "some potential," despite its limited size.

Carim's emphasis on decentralization was endorsed by Tjalke Tjalkens, a Dutch sociologist, employed by the UN. "Long distance migration, especially to Port-au-Prince, is not desirable," Tjalkens declared. "To prevent migration to Port-au-Prince," he thought Bouda should "divide Haiti" into regions, "each with a

78. Institut Haïti de Statistique, "Résultats préliminaires" (1973), tables 1-1-3, 11-4, 1-4-2.

79. Anthony Radspieler, "Problèmes d'Accroissement de la population de Portau-Prince" (1973), 19-20, UNAR, Registry No. TE 322/1, S-0175-0551-01:

"Technical Assistance Mission in Haiti: Physical, Regional, and Urban Planning, 240-1, Part 4."

80. Tarik Carim, "Mission en Haïti du Conseiler Technique," 9-10. 
city or town" that would grow into a "centre d'attraction." ${ }^{81}$ Inspired by Patrick Geddes, Tjalkens insisted that each centre have a unique "development plan" based on regional geography. ${ }^{82}$ Every centre, however, would promote "modern community organization" and provide "education, energy, sewers, [and] sanitary services" to its inhabitants. ${ }^{83}$

Tjalkens' proposal had a lot in common with the Garden City Movement, which began in Britain with Ebenezer Howard in the late nineteenth century. Howard believed that humanity had already achieved an ideal modernity in late Medieval times, when men and women lived in secluded villages that evolved in harmony with nature.$^{84}$ In his book, To-morrow (1898), he included a diagram, "The Three Magnets," that conveyed his vision. The image showed "the people"

81. Tjalke Tjalkens, "Rapport de la mission en sociologie urbaine" (1972), 5, 1517, UNAR, Registry No. TE 322/1, S-0175-0550-05: "Technical Assistance Mission in Haiti: Physical, Regional, and Urban Planning, 240-1, Part 3."

82. Patrick Geddes advocated regional planning in Cities in Evolution (New York: Howard Fertig, 1968), 84-108. Also see The City in History: Its Origins, Its Transformations, and Its Prospects (New York: Harcourt, Brace \& World, 1961), in which Geddes' disciple, Lewis Mumford, touted "organic planning" that moves "from need to need, from opportunity to opportunity, in a series of adaptations that themselves become increasingly coherent and purposeful, so that they generate a complex, final design, hardly less unified than a preformed geometric pattern."

83. Tjalkens, 15-17.

84. Robert Beevers describes Howard's vision in The Garden City Utopia: A Critical Biography of Ebenezer Howard (New York: St. Martin's Press, 1988). Also see Walter L. Creese, The Search for Environment: The Garden City Before and After (New Haven: Yale University Press, 1966); Standish Meacham, Regaining Paradise: Englishness and the Early Garden City Movement (New Haven: Yale University Press, 1999). 
flocking to a town in the countryside, attracted by "bright homes and gardens," "freedom," and "cooperation." 85

Given Howard's emphasis on "cooperation," one would expect Tjalkens to have embraced Haiti's cooperative practices, especially those of the lakou. United by common ancestry and shared spiritual practices, the lakou are communities in the countryside that practice mutual aid. They date back to the sixteenth century, when the quarters of enslaved Africans included a courtyard, which was known as the "lakou." 86 Tjalkens, who knew very little about the peasantry, condemned the lakou as "ancient." ${ }^{87}$ They "must be replaced by modern community organization," like that in Europe, he declared. Otherwise, the peasants would continue to "identify with their family, the lakou," and not the nearby "centre d'attraction." 88

Bouda asked the local sociologist, Hubert de Ronceray, to evaluate Tjalkens' proposal. Ronceray agreed but would not endorse it. "Unacquainted with the Haitian reality and limited by time, [Tjalkens'] research was inevitably incomplete," Ronceray told Bouda. "He was not able to explore more than

85. Ebenezer Howard, To-morrow: A Peaceful Path to Real Reform (London: Swan Sonnenschein, 1898).

86. Luc-Joseph Pierre, Haïti: Vodou, lakou, esclavage et identité (Port-auPrince: Henri Deschamps, 2001), 81-106.

87. Tjalkens cited Aspekte der sozialen und politischen Entwicklung Haitis (Hamburg: Institut für Iberoamerika-Kunde, 1971), 57-60, by Ulrich Fleischmann, a German Marxist, who described the lakou as inherently "dysfunktionalen."

88. Tjalkens, Annex B, 1-2. 
superficially the sociological variables in the territory." ${ }^{89}$ Bouda "much appreciated" Tjalkens' vision. "In general," however," [he] share[d] the [same] objections." 90

While the technicians discounted Tjalkens' advice to break up the lakou, they adopted many of his other ideas. Radspieler embraced the term, "centres d'attraction." He suggested that Bouda identify "a group of secondary cities" that could become "pôles de développement" and "d'attraction." Bouda convened with his colleagues. Haiti had 22 cities, they counted, but only 11 could realistically function as "pôles de développement."92 Jérémie, on Haiti's southern peninsula, and Port-de-Paix, on the northern peninsula, were ideally situated, but the technicians thought Cap-Haïtien, Gonaïves, and Les Cayes should "play the dominant role," since they had larger economies.

Devoted to the "création de pôles d'équilibre régionaux," Bouda invited Europe's preeminent expert on regional planning, Michel Phlipponneau, to Haiti. ${ }^{93}$ As the Professor of Applied Geography at the Université de Rennes in

89. Hubert de Ronceray to Paul-Walter Bouda and Louis Jadotte (8 February 1973), UNAR, Registry No. TE 322/1, S-0175-0550-05: "Technical Assistance Mission in Haiti: Physical, Regional, and Urban Planning, 240-1, Part 3."

90. Paul Walter Bouda to Carmen F. Korn (25 January 1973) and Evner Ergun (12 February 1973), same location as the previous citation.

91. Radspieler, "Problèmes d'accroissement," 20-22.

92. Memo (15 April 1974), UNAR, Registry No. TE 322/1, S-0175-0551-01: "Technical Assistance Mission in Haiti: Physical, Regional, and Urban Planning, 240-1, Part 4."

93. "Arrivée de M. Michel Phlipponneau," Le Nouveau Monde (13 November 1973): 1. Also see Vaidyanathan Kandaswamy to Jan Van Heerden (13 March 
France, Phlipponneau believed that "urbanization should accommodate the [region's] agrarian structure, the given habitat, and the environment's preexisting modes of land usage." "94 Upon arrival, he insisted that a "regional planning policy" was "indispensable" should Haiti "want to slow migration and limit [the] rapid expansion [of Port-au-Prince]. ${ }^{95}$

Bouda also turned to an organization that was knowledgeable about garden cities: $\mathrm{FCH}$. The founder of $\mathrm{FCH}$, Clarence Stein, was a member of the Regional Planning Association of America and had designed the quintessential garden city, Radburn, New Jersey, in $1928 .{ }^{96}$ His company, $\mathrm{FCH}$, rehabilitated Greenbelt, Maryland, a bankrupt "Tugwelltown," built in 1936 by the New Deal Resettlement Administration. ${ }^{97}$

1974), UNAR, Registry No. TE 322/1, S-0175-0551-01: "Technical Assistance Mission in Haiti: Physical, Regional, and Urban Planning, 240-1, Part 4."

94. Michel Phlipponneau, La vie rurale de la banlieue parisienne (Paris: Librarie Armand Colin, 1956), 20. Also see Géographie et action (Paris: Librarie Armand Colin, 1960).

95. Michel Phlipponneau, "Rapport d'activites semestriel," annex 2, "Rapport de recherche en planification physique" (July-December 1973), UNAR, Registry No. TE 322/1, S-0175-0550-05: "Technical Assistance Mission in Haiti: Physical, Regional, and Urban Planning, 240-1, Part 3."

96. Clarence Stein expressed his interest in the Garden City Movement in his correspondence with Roger Willcox (1953-1965), Clarence Stein Papers, boxes 3 , 4, and 8. Carl A. Kroch Library, Division of Rare Books and Manuscripts, Cornell University, Ithaca, New York.

97. Joseph L. Arnold, The New Deal in the Suburbs: A History of the Greenbelt Town Program (Columbus: Ohio State University Press, 1971). Also see David Myhra, "Rexford Guy Tugwell: Initiator of America's Greenbelt New Towns, 19356," in The American Planner: Biographies and Recollections, ed. Donald A. Krueckeberg (New York: Methuen, 1983). 
Bouda wanted FCHI to support community organization in Haiti. He noted how Stein admired Clarence Perry, the renowned sociologist who wanted to divide New York into massive blocks, each with a "community center" and spontaneous, "organic" pathways. In every nook and cranny, Perry theorized, people would bond, and that solidarity would elevate the community as a whole. ${ }^{98}$ Like Perry, FCHI promoted mutual aid..$^{99}$ "Residents [should] get to know one another and establish an identity with the community," explained Robert Dodge. "This, plus the fact that there is a mutual interest on the part of the members in the community as a whole, tends to generate a healthy social climate." 100

In 1976, Louis Jadotte and Frédérick Mangonès, the son of Albert Mangonès, participated in "Habitat I," a conference on human settlements, organized by the UN in Vancouver. ${ }^{101}$ Habitat I, they decided, was the best opportunity to announce Bouda's plan to promote community organization,

98. Clarence Perry, The Neighborhood Unit, in Neighborhood and Community Planning (New York: Committee on the Regional Plan of New York and Its Environs, 1929), 126.

99. Wallace J. Campbell, Here is Tomorrow: Consumer Cooperatives in America (New York: CLUSA, 1941), 32. 8.

100. J. Robert Dodge, Cooperative Housing (Washington, D.C.: HUD, 1971), 7-

101. Habitat I yielded the "The Vancouver Declaration on Human Settlements" (1976), UN Documents, General Assembly, Conference on Human Settlements, A/CONF.70/Misc.1/Rev.2 (microfiche), 70. It upheld "the improvement of the quality of life of human beings" as the "most important objective of every human settlement policy." 
"geographically balanced economic development," and "a rational redistribution of the [Haitian] population." 102 They unveiled a map that divided Haiti into regions. Cap-Haïtien, Gonaïves, and Les Cayes were labeled as "centres régionaux." Jérémie, Port-de-Paix, and Hinche were "centres sous-régionaux" and "centres secondaire."

Bouda and his colleagues did not know if Duvalier would support them. They searched for clues in the president's speeches, as they anxiously awaited his Plan quinquennal. ${ }^{103}$

Shockingly, Duvalier asked Bouda to help compose the Plan-an honor rarely bestowed upon non-Haitians. ${ }^{104}$ Bouda happily inserted a line that stated: "we must rationally redistribute the population across the country" by "develop[ing...] cities that will become pôles de croissance." ${ }^{105}$ He likely had a

102. Gérard Hippolyte, Louis Jadotte, Albert Mangonès et al., "Habitat" (1976), 22-25, UNAR, Registry No. TE 322/1, S-0175-0553-01: "Technical Assistance Mission in Haiti: Physical, Regional, and Urban Planning, 240-1," enclosed in an envelope. Also see "Logement: Habitat '76," Le Petit Samedi Soir 4, no. 147 (29 May-4 June 1976): 22.

103. Ottorino Jannone to Jan Van Heerden (6 December 1974), UNAR, Registry No. TE 322/1, S-0175-0551-02: "Technical Assistance Mission in Haiti: Physical, Regional, and Urban Planning, 240-1, Part 5." Also see the annotated news clippings that Bouda enclosed in his correspondence with Van Heerden (7 January 1974), same location, Registry No. TE 322/1, S-0175-0551-01:

"Technical Assistance Mission in Haiti: Physical, Regional, and Urban Planning, 240-1, Part 4."

104. Evner Ergun to Jan Van Heerden (2 December 1975), UNAR, Registry No. TE 322/1, S-0175-0552-01: "Technical Assistance Mission in Haiti: Physical, Regional, and Urban Planning, 240-1, Part 6."

105. CONADEP, Plan quinquennal, 1976-1981, vol. 1 (Port-au-Prince: Imp. de l'Etat, 1976), 2-5. 
hand in the conclusion, too. "The policy of [the Haitian] government," it proclaimed, "is based on decentralization."

\section{Urban Realities}

In retrospect, Duvalier might not have read what Bouda slipped into the Plan quinquennal, given that Pierre Petit immediately confronted the technicians, condemning the Plan as a pipe dream. Bouda had placed Petit in a "difficult position," because while the Plan quinquennal advocated decentralization, the "public sector," as a whole, and "more importantly, the private sector," demanded "immediate action" in the capital. ${ }^{106}$

Commissioned to help Port-au-Prince and not the provinces, PADCO sided with Petit. Jadotte and Mangonès protested that PADCO "does not [understand] the interdependence" of "national" and "metropolitan" development. ${ }^{107}$ Michel Phlipponneau agreed. "It is unacceptable" that PADCO "ignore the desire of the Haitian government!" he exclaimed. ${ }^{108}$

106. Memo (3 April 1975), in "Directives pour la stratégie développement de Port-au-Prince et de sa région métropolitaine" (1975), UNAR, Registry No. TE 322/1, S-0175-0551-02: "Technical Assistance Mission in Haiti: Physical, Regional, and Urban Planning, 240-1, Part 5."

107. Louis Jadotte and Albert Mangonès to Paul-Walter Bouda (no date), UNAR, Registry No. TE 322/1, S-0175-0551-02: "Technical Assistance Mission in Haiti: Physical, Regional, and Urban Planning, 240-1, Part 5."

108. Michel Phlipponneau to Jan Van Heerden (29 December 1974) and Evner Ergun (29 December 1974), same location as the previous citation. 
UN policymaker Evner Ergun quickly intervened. The Master Plan, she reminded everyone, "is not a national physical development strategy." Rather, "the project aims at the preparation of a development plan for the Port-au-Prince metropolitan area within the context of its region." ${ }^{109}$ She sympathized with the technicians but would not uphold the so-called "decentralization policy" in the Plan quinquennel. Haiti needed "an emergency program to gain some economic momentum in Port-au-Prince," she stated. If successful, "[it] can be the basis for the future growth in the regions."

Ergun's emphasis on Port-au-Prince became all the more pertinent on 27 February 1975, when a fire destroyed nearly 1,000 homes in St. Martin. Duvalier dispatched Macoutes to compensate the victims and promised them a "long term plan to build adequate new homes." ${ }^{110}$ PADCO and CONADEP quickly went to work. Meanwhile, Bouda asked FCHI to send two consultants, Lawrence Salmen and Hank Boldrick, to help with "institutional problems." "111

Salmen and Boldrick would advise the Office National du Logement (ONL). Founded in 1966, the ONL was built upon the Office d'Administration

109. Evner Ergun, "Report on the Mission to Haiti" (1974), 3-5, UNAR, Registry No. TE 322/1, S-0175-0551-02: "Technical Assistance Mission in Haiti: Physical, Regional, and Urban Planning, 240-1, Part 5."

110. "Décisions du Président à Vie de la République en faveur des familles sinistrées" and "L'événement incendie à St. Martin," Le Petit Samedi Soir, no. 87 (1-7 March 1975): 1-4.

111. PADCO, "Rapport d'avancement phase trois" (28 February 1977), UNAR, Registry No. TE 322/1, S-0175-0552-02: "Technical Assistance Mission in Haiti: Physical, Regional, and Urban Planning, 240-1, Part 7." 
des Cités Ouvrières (OACO), which had promoted low-income housing in Haiti since $1951 .{ }^{112}$ Led by Auguste Maingrette, it employed 39 technicians, whose yearly budget was only 300,000 US dollars. ${ }^{113}$ "Most [ONL personnel] were not experienced in more than the usual 'brick and mortar' activities," explained FCHI. "Thus, a great deal of emphasis had to be placed on building the institutional capability of the ONL to respond to... the bidonville population." ${ }^{114}$

Bouda insisted that PADCO, CONADEP, FCHI, and the ONL avoid unnecessary destruction in St. Martin. When the daily Le Matin printed the term "à élimer" by accident, he crossed it out with a red pen and wrote "à ameliorer." ${ }^{115}$ The technicians surveyed St. Martin to determine which homes were salvageable. They only demolished 288 structures, and in the space they

112. As explained by the ONL in Eléments pour une politique rationnelle de logement en Haïti (Port-au-Prince: Presses Nationales d'Haïti, 1979), 14, the Office implemented "a housing policy that [was] pragmatic" and "improve[d] the standard of living." Also see Colbert Bonhomme, Logement ouvrier populaire (Port-au-Prince: Les presses de la Cie. Litho. d'Haïti, 1958), 20-21; OACO, La voix des cités ouvrières d'Haïti (Port-au-Prince: Imp. de l'Etat, 1955).

113. Louis Berger International, Inc., "ONL," in Projets et planification en Haïti, vol. 4, Logement (Port-au-Prince: Imp. de l'Etat, 1977). Also see USAID, "Shelter Sector Assessment: Haiti" (1980).

114. FCHI, "From Survival to Development: A Self-Help Approach to Community Upgrading" (1983), 15. Also see Simon M. Fass, "The St. Martin Project: A Decade of Pain and Progress in the Evolution of an Urban Development Institution," in Politics, Projects, and People: Institutional Development in Haiti, eds. Derick W. Brinkerhoff and Jean-Claude Garcia-Zamor (New York: Praeger, 1986).

115. "La conférence de l'ingénieur Bouda," Le Matin (12 March 1974), UNAR, Registry No. TE 322/1, S-0175-0551-01: "Technical Assistance Mission in Haiti: Physical, Regional, and Urban Planning, 240-1, Part 4." 
cleared, the ONL built 14 public latrines. It also installed fire hydrants, street lamps, and storm drains. ${ }^{116}$

Asked to design 800 new homes, FCHI and CONADEP kept them very simple. Bidonvilles like St. Martin exist because "people can't afford a standard house," explained FCHI technician Jack Edmondson. "Housing policy must be based upon what the national economy and what those to be housed can afford." ${ }^{117}$ Since the average income in St. Martin was only 10 to 40 US dollars a month, CONADEP proposed a home with only two rooms and no private bathroom (Fig. 19). This was the "absolute minimum," it proudly stated. "At night, the first [room] serves as a bedroom for the children, and during the day, it becomes a living room." The second room, it explained, "is for the parents," and "behind the house is a semi-enclosed, charcoal stove and a courtyard for various household activities."118

While the Haitian government owned an empty lot next to St. Martin, it did not have enough money to build a "Nouveau St. Martin." Hence, the FCHI technician, Raimundo Guarda, proposed a housing cooperative, like the one in

116. CONADEP and the UNDP, "Avant projet pour la réhabilitation du quartier St. Martin," table 4.1 and map 7.

117. Jack Edmondson, "Cooperative Housing as One Solution to Meeting the Problems of the Urban Poor" (1977), in FCHI, "Development Program Grant Report" (1 November 1977-30 April 1978). Also see FCHI and USAID, Cooperative Housing and the Minimum Shelter Approach in Latin America (Washington, D.C.: FCHI, 1972).

118. CONADEP and the UNDP, "Avant projet pour la réhabilitation du quartier St. Martin," 40. 


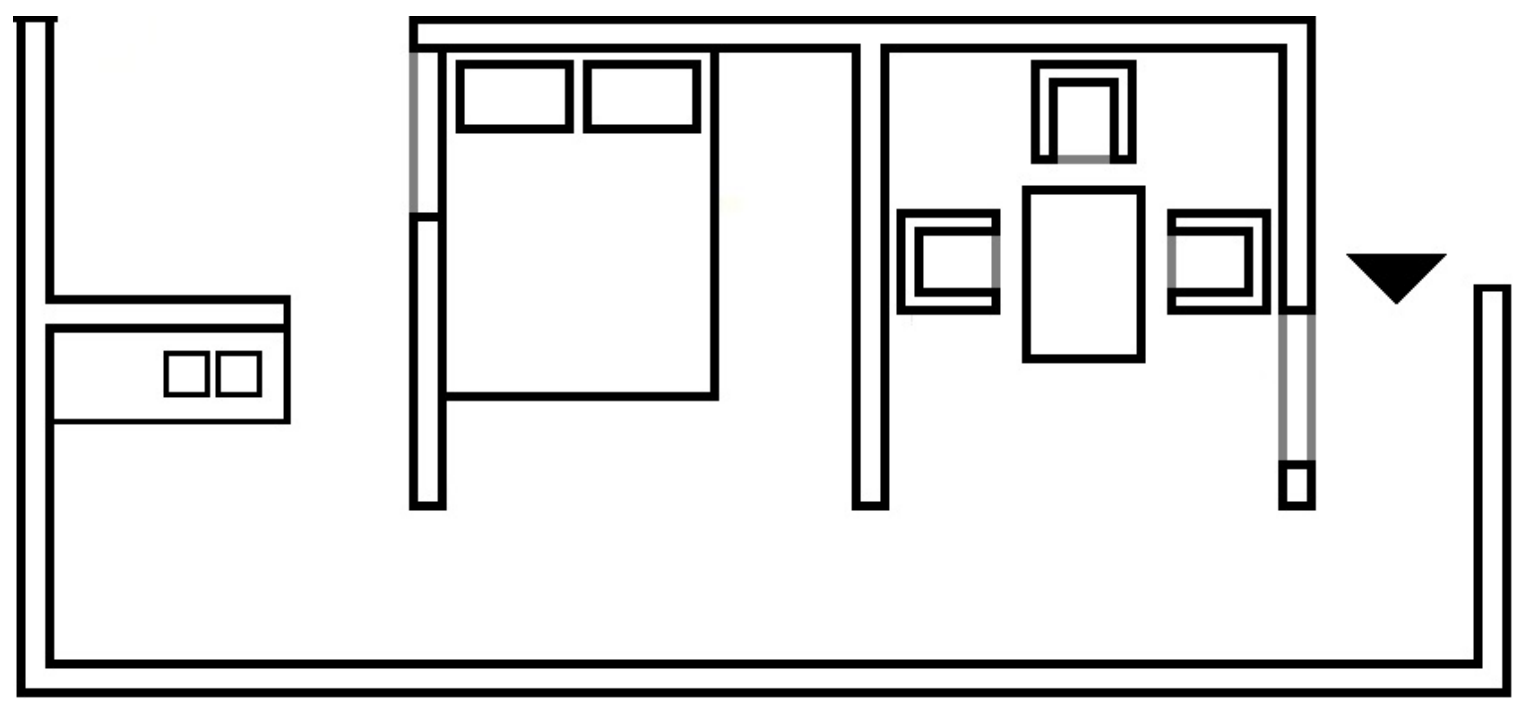

Fig. 19 Plan for Model Homes in St. Martin. A sketch by Adam M. Silvia based on multiple blueprints in "Avant projet pour la réhabilitation du quartier St. Martin" (1977), United Nations Archives, Registry No. TE 322/1, S-0175-0555-03:

"Technical Assistance Mission in Haiti: Institutional Strengthening in Physical and Urban Planning, 240-3, Part 1."

Greenbelt, Maryland. ${ }^{119}$ Maingrette embraced the idea. He would provide the community with tools, while his aide, Franz Jérémie, obtained cement and sheet metal. ${ }^{120}$ Nearly 700 households joined the cooperative. Each received a complementary title but had to pay for the construction materials. Aided by FCHI, Maingrette introduced a "rental purchase system," in which "[home] ownership was possible through a fixed-rate mortgage." ${ }^{121}$ Materials to build a $32 \mathrm{~m}^{2}$ unit cost 1,100 US dollars. The occupants would pay back 11 US dollars a month,

119. Mario Lopez, Untitled Report (20 May 1980), in ONL, Rénovation urbaine et construction de logements sociax (Port-au-Prince: Imp. De l'Etat, 1980).

120. Franz Jérémie and Lance Durban, Untitled Report (20 May 1980), same location as the previous citation.

121. FCHI, "From Survival to Development," 14. 
and owe 12 percent interest. ${ }^{122}$ The ONL vowed to invest this money back into St. Martin.

The ONL also created an "organisation service technique" to supervise the construction of Nouveau St. Martin. As explained by FCHI, the organisation "would make up a detailed plan" and introduce "by-laws" to "speed up the cooperative housing program." ${ }^{123}$ Founded in March 1978, the "conseil d'administration" included the Mayor of Port-au-Prince, Raymond Roy, and Pierre Petit's brother, Raymond Petit. It was "Jean-Claudisme en action!" they exclaimed. ${ }^{124}$

Not everyone supported the organisation service technique. One opponent was Jonas Georges, a loyal Duvalierist, who owned nearly 20 homes in St. Martin. When the ONL demolished 15 of his houses, Georges and his 95 tenants took to the streets in protest. ${ }^{125}$ Threatened by the local slumlord, the ONL had little choice but to ally with the Tonton Macoutes and appoint them to the conseil d'administration. Maingrette summoned two Chef Macoutes, Olaff Antoine and Servius Durand, to St. Martin. Antoine "identified himself as a

122. ONL, Rénovation urbaine et construction de logements sociaux, 8-10.

123. FCHI and USAID, "Ingredients for a Successful Self-Sustaining Cooperative Housing Program" (1966), 27. Also see "Legal Aspects of Cooperative Housing," CHF Concepts and Methods Series, no. 4 (1982): 1-2.

124. "Installation du Conseil d'Administration," in ONL, Eléments pour une politique rationnelle de logement en Haïti, 201-4.

125. CONADEP and the UNDP, "Avant projet pour la réhabilitation du quartier St. Martin," annex 1, "Enquête le terrain de St. Martin." 
representative of the Président à Vie, sent to quell subversive activity and thwart the bad intentions of those who opposed the project." ${ }^{126}$ Georges' supporters immediately dispersed. Georges, meanwhile, insisted "energetically" that "he was no longer opposed to the project's implementation." ${ }^{127}$

By contrast, $\mathrm{FCHI}$ wished to promote voluntary cooperation in St. Martin. Toward this end, FCHI technician Mario Lopez invited community leaders to Los Pocitos, a village in western Panama, where they observed the company's partnership with USAID and the Panamanian campesinos. ${ }^{128}$ The Haitians noted how the community worked cooperatively to improve upon its tiny bohios and obtain a "good standard [of living]."129

When they got back to St. Martin, FCHI helped them build a community center, like the ones envisioned by Clarence Perry. Located between Vieux St. Martin and Nouveau St. Martin, the center was both a recreational facility and a space for "educational and motivational meetings" about "construction, hygiene, civics, [and] family planning." ${ }^{130}$ According to Mario Lopez, it was "a very positive

126. ONL, Rénovation urbaine et construction de logements sociaux, 11-12.

127. Ibid.

128. Lopez, Untitled Report, 12-13.

129. FCHI, Housing the Campesino: A Case Study of Cooperative Housing in Rural Panama (1966), 1-2, 21. Also see "Self-Help Co-op House in Rural Panama," FCH News Briefs 2, no. 11 (Nov. 1965): 3.

130. ONL, "Centre communautaire," in Projet de développement urbain. Etude de factibilité: sites et services (Port-au-Prince: Imp. de l'Etat, 1980), A25. Also see Jason P. Mason, "Miracle on Ave. St. Martin: A Lesson in Self-Help Housing from Port-au-Prince" (Washington, D.C.: FCHI, 1981). 
element for the improvement of neighborhoods" and "signaled the will of [the community] to improve [the] living conditions in St. Martin." ${ }^{131}$

The center was also home to the "Coopérative d'Habitation de St. Martin," an autonomous organization that inherited the ONL's task to rehabilitate the bidonville. As noted by FCHI, the Coopérative had a rocky start, because money was misappropriated. ${ }^{132}$ It came through, however, when a fire destroyed nearly 1,500 homes in 1982. FCHI noticed a "strong sense of community."

Despite this accomplishment, the technicians disavowed the Master Plan. Everyone "emphasized the need for balanced regional growth," FCHI lamented. "Investments made in the capital" would only "further concentrate economic and population growth in the city." Migrants, the company explained, would continue to "optimize their life chances by coming to places such as St. Martin." ${ }^{133}$ Bouda eventually persuaded the CHBP to commission an "étude régionale" in the Central Plateau, but his advice to create new "centres régionaux" went unheeded. ${ }^{134}$

131. Lopez, Untitled Report, 48-49.

132. FCHI, "From Survival to Development," 26.

133. Ibid., 11.

134. Evner Ergun to Jan Van Heerden (19 April 1976), UNAR, Registry No. TE 322/1, S-0175-0552-01: "Technical Assistance Mission in Haiti: Physical, Regional, and Urban Planning, 240-1, Part 6." Also see Paul-Walter Bouda and Helmut Sauermilch, "Etude régionale du Plateau Central" (1976), UNAR, Registry No. TE 322/1, S-0175-0553-01: "Technical Assistance Mission in Haiti: Physical, Regional, and Urban Planning, 240-1," enclosed in an envelope. 
Nevertheless, the Master Plan was not a complete washout. It increased the standard of living in St. Martin, and the ONL went on to improve the nearby slums of La Saline, Boston, and Cité Simon.

The Master Plan had a concrete impact on people's lives, but it did not yield the just society desired by Bouda and his colleagues. Outside St. Martin, there was a visible disparity between ideas and reality—between what the technicians envisioned and what they actually accomplished. The Master Plan had many additional components, but they were mostly ignored. The UN shelved them in its archives, and 30 years later, employees at $\mathrm{FCHI}$ had no memory that they even existed. That said, nearly 1,000 "Model City" proposals also lay untouched in Washington.

The Master Plan, like the Great Society, was largely a disappointment. One can even apply to Haiti what Aaron Wildavsky said about the War on Poverty. "Promise a lot," but "deliver a little," Wildavsky quipped. ${ }^{135}$ "Avoid any attempted solution remotely comparable in size to the dimensions of the problem you are trying to solve." Next, "get some poor people involved in local decisionmaking, only to discover that there is not enough at stake to be worth bothering about.... Feel guilty about what has happened to black people; tell them you are surprised they have not revolted." When they do protest, apply "a little suppression." Finally, "mix well, apply a match, and run."

135. Aaron Wildavsky, "A Simple Recipe for Violence," in Maximum Feasible Misunderstanding: Community Action in the War on Poverty (New York: The Free Press, 1969) by Daniel Patrick Moynihan. 


\section{CENTRAL PLANNING AND THE NEW RIGHT}

"I see myself as a liberal-in the old fashioned sense," Leslie Delatour proclaimed. ${ }^{1}$ Delatour, a Haitian economist, was trying to explain his position on technocracy to Lawrence W. Reed, the Director of the Center for the Study of Market Alternatives in Idaho (Fig. 20). Educated by the University of Chicago, which specialized in neoclassical economics, Delatour embraced "neoliberalism," a philosophy that advocates free-market capitalism. ${ }^{2}$ "One thing I learned [at the University of Chicago] from [Professor] George Stigler," he noted, "is that you don't pretend to know [more] about somebody else's business than the guy who's doing it." Like Stigler, Delatour loathed price controls and public services. ${ }^{3}$

1. Leslie Delatour with Lawrence Reed in Reason (Jul. 1987): 33-35.

2. As explained by Jamie Peck in Constructions of Neoliberal Reason (New York: Oxford University Press, 2013), 19-20, neoliberalism promotes "market-like rule... occupying the ideological space defined by a sympathetic critique of nineteenth-century laissez-faire [capitalism] and [subsumes] deep antipathies to collectivist, planned, and socialized modes of government, especially those associated with Keynesianism." Also see A Brief History of Neoliberalism (New York: Oxford University Press, 2007), 2, in which David Harvey describes neoliberalism as "a theory of political economic practices that proposes that human well-being can best be advanced by liberating individual entrepreneurial freedoms and skills within an institutional framework characterized by strong private property rights, free markets, and free trade."

3. George Stigler literally wrote the book on the price system. The Theory of Price (New York: Macmillan, 1966), 15, explains how "[it] gives innumerable messages on the state of supply and demand for each commodity or service at each place where it is bought or produced." Also see Masters of the Universe: Hayek, Friedman, and the Birth of Neoliberal Politics (Princeton: Princeton 


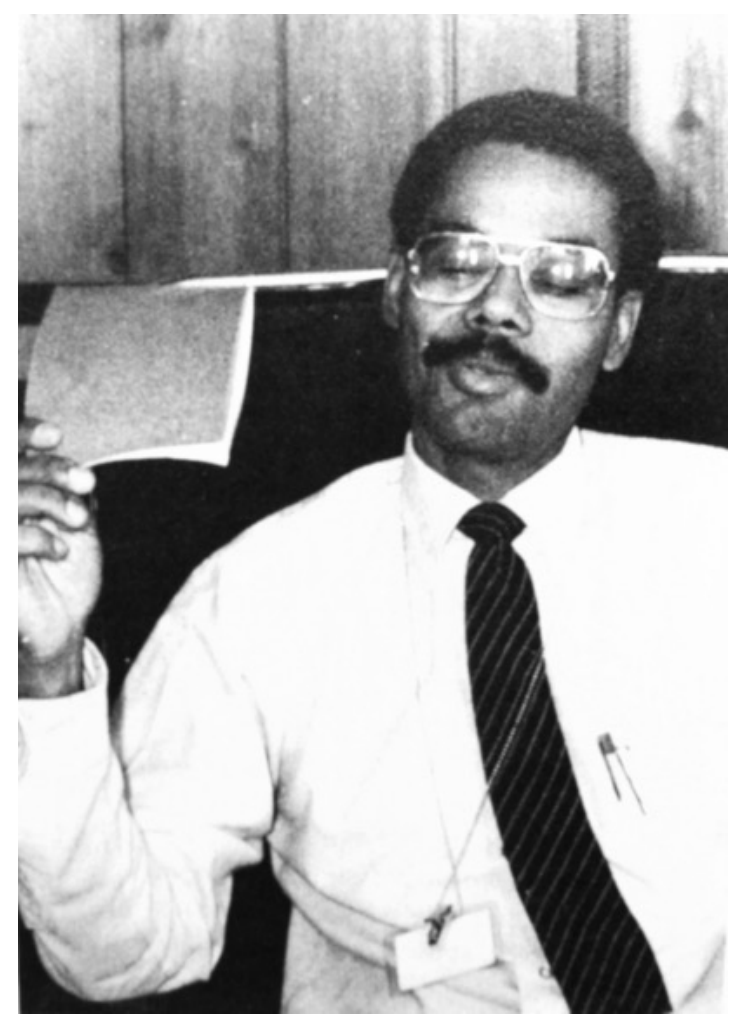

Fig. 20 Leslie Delatour, Ministre de Finance. From: Reason (Jul. 1987): 34. Reproduced with permission.

"It [is] not my job to take people by the hand and do things for them!" he exclaimed.

Delatour's philosophy resonated with local businessmen, who resented how the Duvaliers instituted monopolies and manipulated prices to reward loyal supporters. It also appealed to conservatives in the US, such as President Ronald Reagan. ${ }^{4}$ When a military coup toppled the Duvaliers in February 1986 ,

University Press, 2012) by Daniel Stedman Jones, who documents how the University of Chicago promoted neoliberalism.

4. In the book, Invisible Hands: The Making of the Conservative Movement from the New Deal to Reagan (New York: W.W. Norton \& Company, 2009), Kim Phillips-Fein analyzes how conservatives like Reagan challenged the Great Society. Also see Angus Burgin, The Great Persuasion: Reinventing Free 
Reagan and the business community encouraged the provisional junta, led by Lieutenant-General Henri Namphy, to appoint Delatour as Ministre des Finances.

Unlike previous technicians, Delatour lauded the capitalist world-economy. His vision, however, was nonetheless utopian. He imagined what Ruth Levitas describes as the "New Right Utopia:" a just society built upon neoclassical economics and conservative values. ${ }^{5}$ Led by Ronald Reagan and his British counterpart, Margaret Thatcher, the "New Right" evolved in response to Soviet ideology in the East and "creeping socialism" in the West. ${ }^{6}$ It bewailed how "the whole philosophy of [central] planning rests on the principle that owners do not have the right to do what they like with their own property." Reagan and Thatcher insisted that "this is not a just principle."7 Hence, Delatour wanted to promote "natural laws," such as supply and demand. Only then, he argued, would Haiti experience liberty and ascend to castles in the air. ${ }^{8}$

Markets since the Depression (Cambridge: Harvard University Press, 2012); Mark A. Smith, The Right Talk: How Conservatives Transformed the Great Society into the Economic Society (Princeton: Princeton University Press, 2007).

5. Ruth Levitas, "New Right Utopias," Radical Philosophy 15, no. 39 (Spring 1985): 2-9.

6. Steven F. Hayward analyzes the New Right in The Age of Reagan: The Conservative Counterrevolution, 1980-1989 (New York: Crown Forum, 2009). Also see Matthew D. Lassiter, The Silent Majority: Suburban Politics in the Sunbelt South (Princeton: Princeton University Press, 2007); Lisa McGirr, Suburban Warriors: The Origins of the New American Right (Princeton: Princeton University Press, 2001).

7. Ruth Levitas, "Competition and Compliance: The Utopias of the New Right," in The Ideology of the New Right (Cambridge: Polity Press, 1986), 90-91.

8. In his book, Castles in the Air (Irvington: FEE, 1975), 6, Leonard A. Read, a protégé of Ayn Rand, imagined "a freeing of the human spirit-tens of millions no 
Delatour perceived the vision of the New Right as the ideal alternative to Duvalierism, which he detested. In conversation with Lawrence Reed, he bemoaned how the Duvaliers were "engaged in a massive effort to create artificial profits for the benefit of [themselves] and [their] friends and families." The "guy who was married to the sister of [Jean-Claude's] wife [Michèle]," he complained, "had a monopoly on copper electric cables," and "the brother of the head of the palace guard had [one] on polyvinyl bags." There were "monopolies on milk, caps for soft drinks bottles, steel, flour sacks, and tin roofing." These businesses were inefficient, he explained, because they lacked competition. As a result, goods were expensive and poverty increased.

By contrast, Delatour associated the market economy with prosperity. The business community, he reasoned, was no less greedy than the Duvaliers. In a free market, however, that greed would sustain healthy competition. Like the novelist, Ayn Rand, he believed that "selfishness" was actually a "virtue," but only in the context of "pure, uncontrolled, unregulated, laissez-faire capitalism." ${ }^{10}$ It was thus his duty as a technician to destroy the Duvaliers' monopolies and incorporate Haiti back into the capitalist world-economy.

longer wards of government but growing, emerging, self-responsible citizens, each his own man." Toward this end, he created the Foundation for Economic Education (FEE) in 1946. The FEE is currently led by Lawrence Reed.

9. Delatour in Reason, 33-35.

10. Ayn Rand, The Virtue of Selfishness: A New Concept of Egoism (New York: Signet, 1989, originally published in 1964), 25. 
While the New Right outwardly condemned central planning, it promoted a whole new technocracy—led by the International Monetary Fund, the World Bank, and USAID—to manage the world-economy. ${ }^{11}$ Aided by USAID, Delatour manipulated the money supply to stimulate private investment. He also promoted new laws that enabled Haitian businesses to partner with multinational corporations. ${ }^{12}$ As stated by Nikolas Rose, "neoliberalism does not abandon the will to govern." To the contrary, "it maintains the view that [the] failure of government to achieve objectives is to be overcome by inventing new strategies of government that will succeed. ${ }^{13}$ Hypocrisy on a grand scale, neoliberalism constituted a "complete superimposition of market mechanisms" on society. ${ }^{14}$

As Ministre des Finances, Delatour invited local businessmen and multinational corporations to open assembly plants and exploit the country's

11. Gérard Duménil and Dominique Lévy make this point in Capital Resurgent: Roots of the Neoliberal Revolution (Cambridge: Harvard University Press, 2004).

12. In the book, Globalization and the American Century (New York: Cambridge University Press, 2003), Alfred E. Eckes, Jr. and Thomas W. Zeiler explain how the US promoted laws that helped multinationals move seamlessly across national borders. Also see G. John Ikenberry, Liberal Leviathan: The Origins, Crisis, and Transformation of the American World Order (Princeton: Princeton University Press, 2011); Geoffrey Jones, Multinationals and Global Capitalism from the Nineteenth Century to the Twenty-First Century (New York: Oxford University Press, 2005).

13. Nikolas Rose, "Governing 'Advanced' Liberal Democracies," in Foucault and Political Reason: Liberalism, Neo-Liberalism and Rationalities of Government, eds. Andrew Barry, Thomas Osborne, and Nikolas Rose (Chicago: University Press of Chicago, 1996), 53.

14. Michel Foucault, The Birth of Biopolitics: Lectures at the Collège de France, 1978-1979, ed. Arnold I. Davidson (Basingstoke: Palgrave Macmillan, 2008), $120-21$. 
"comparative advantage," i.e. the "excess" population in Port-au-Prince. He championed neoliberalism, but many Haitians opposed it. In his book, Néolibéralisme: crise économique et alternative de développement (1990), Fritz Deshommes describes how Delatour's philosophy worsened income inequality, since the average pay in assembly plants was abysmal. ${ }^{15}$ Neoliberalism exacerbated Haiti's dependency on the modern world-system and enabled multinationals to prey upon impoverished women, who desperately needed work. $^{16}$

Delatour, I argue, was sincerely interested in the Haitian people. He despised the Duvaliers and desired a just society. His vision for national liberty, however, was grossly inadequate. Protesters noted how the new assembly lines resembled plantation slavery. They implicated Delatour in a conspiracy to undermine Haitian sovereignty and demanded he step down.

15. Fritz Deshommes, Néo-libéralisme: crise économique et alternative de développement (Port-au-Prince: N.p., 1993), 23-32. Also see Echec du pouvoir olgarchique et alternative de changements en Haïti (New York: Hunter College, 1984), 13, in which Gérard Pierre-Charles and Suzy Castor explain how "technicians and corporations... wanted to make Haiti the Taiwan of the Caribbean."

16. Mireille Neptune Anglade exposes the ways in which assembly plants abused women in L'autre moitié du développement, 191-97. Also see Fred Doura, Mondialisation: exclusion sociale et marginalisation des pays sousdéveloppés (Montréal: CIDHICA, 1998). 


\section{The Road to Serfdom}

While many Haitians disliked Delatour, his vision resonated with business owners who desired an alternative to central planning. The business community loathed the Duvaliers, because they sanctioned monopolies that punished the economy as a whole. For example, take Caribbean Mills, Inc., a flour mill built in Port-au-Prince by the Texas oil mogul, Clint Murchison, Jr., in 1957. Murchison's associate, Edouard J. Khawly, had donated between 25,000 and 65,000 US dollars to François Duvalier's presidential campaign, so Duvalier licensed the company as a monopoly. ${ }^{17}$ The deal was that Murchison would sell his flour exclusively to the Bureau de Control des Articles de Première Necessité, which supplied bakeries throughout the country. The Bureau, however, employed a Chef Macoute named Elois Maître, who pocketed 4,000 to 5,000 US dollars a month in excess delivery fees. ${ }^{18}$ The Bureau also collected 2 percent commission and a 30 percent excise tax, which inflated the price of flour.

The business community also resented how Luckner Cambronne, the Ministre des Travaux Publics, preyed upon private enterprises. Cambronne pressured business owners to purchase "economic liberation" bonds. He also

17. R.C Porter, Memo (14 June 1963), ECGR, box 51: "551.3: Flour, 19621964," 1719625. Murchison also owned the Haitian-Meat and Provision Company, known as HAMPCO.

18. Norman E Warner, Memo (6 September 1963), same location as the previous citation. Also see R.C. Porter, Memo (10 July 1963), which includes statistical evidence given to the US Embassy by Caribbean Mills. 
demanded they "donate" 20 US dollars a month to his organization, the Mouvement National de Rénovation (MNR), which built the ill-advised DuvalierVille outside Port-au-Prince. When one entrepreneur, Fouad Mourra, chose not to pay, Macoutes told him "that they wished he would do something out of line so that they could come in and loot his shop." ${ }^{19}$ The MNR threatened others by saying, "you have too much-you should share it with the people," and "to get people like you, we'll pass a law."20

Clifford Brandt, the son of Haiti's wealthiest merchant, Oswald Brandt, spoke plainly that "the business community was fed up with Duvalier." ${ }^{21}$ When solicited by the MNR to support Duvalier-Ville, he exclaimed "that he would not under any circumstances contribute a cent to such an obviously worthless project!" Since he would not comply, the government withheld his export license. Brandt warned the US that "no Haitian with any capital would invest in Haiti under the present political conditions."

19. A. Hugh Douglas, Jr., Memo (1 December 1961), Bureau of Inter-American Affairs, Office of the Director for Caribbean Countries, Records Relating to Haiti, 1960-1974 (IAAR), box 3: "Haiti Memoranda, Sep. 1961," 4692245. General Records of the Department of State, 1763-2002, Record Group 59, Entry No. A13152, NACP.

20. David R. Thomas, Memo (4 December 1961), same location as the previous citation. Also see Philip P. Williams, Memo (27 November 1961) and David R. Thomson, Memo (22 and 24 November 1961), IAAR, box 3: "DuvalierVille Committee, 1961," 4692231.

21. Charles Thomas, Memo (31 December 1961), IAAR, box 3: "Haiti Memoranda, Sep. 1961," 4692245. 
The business community was also annoyed when Macoutes told workers to go on strike unless it gave in to arbitrary demands. The Duvaliers co-opted both the Fédération Ouvrière Paysanne and the Syndicat des Chauffeurs, which they used to harass private enterprises. ${ }^{22}$ The Haytian-American Sugar Company (HASCO) reported that "the company was expected to contribute 50,000 [US dollars to an unannounced 'worker education program'] and failure to contribute would result in labor union difficulties which probably would prevent the company from commencing scheduled grinding operations." ${ }^{23}$ Meanwhile, a "two-gun Tonton Macoute" warned the Haitian Agricultural Corporation (HACOR) that he would invade the company's sisal plantation with "2,000 militiamen" unless it met his personal demands. ${ }^{24}$

Disillusioned with the Duvaliers, one businessman, André Apaid, let his employees plot to overthrow the government. While managing the TV station, Télé-Haïti, Apaid learned that his assistant planned to smuggle guns aboard Pan

22. Charles Thomas, Memo about Macoutes in the Syndicat des Chauffeurs (4 June 1962), ECGR, box 51: "560: Labor Affairs," 1719625. Also see Michel Hector, Syndicalisme et socialisme en Haïti, 1932-1970 (Port-au-Prince: Henri Deschamps, 1987), 129-30; Mats Lundahl, "The Rise and Fall of the Haitian Labor Movement," in Politics or Markets, 343-69.

23. Forrest Abbuhl, Memo (27 November 1961), IAAR, box 3: "Haiti Memoranda, Sep. 1961," 4692245. Also see Charles Thomas, Memo (22 December 1961), same location, which explains how the local manager of the Curaçao Trading Company "pa[id the 'Duvalierist labor leader,' Jacques] St. Lôt 50 [US dollars] a month [so that St. Lôt would] le[ave] his union [at the company] alone."

24. Charles Thomas, Memo (20 June 1962), ECGR, box 51: “560: Labor Affairs," 1719625. 
American Airways, but he chose not to report it. ${ }^{25}$ One day, however, Macoutes showed up and took his assistant away. Saddened by the man's disappearance, Apaid would help others escape the country. He was eventually caught and had to spend nearly a week in jail. ${ }^{26}$

In a bid to win back the business community, Jean-Claude Duvalier replaced Luckner Cambronne with responsible specialists. He also dispatched a CONADEP technican, Jean-Robert Estimé, to organize a new industrial park in Delmas, next to Port-au-Prince. The government built "2.4 kilometers of internal roads," Estimé explained. ${ }^{27}$ It installed "electricity, water, telephone, telex, etc." It also gave tax exemptions to businesses in the park. ${ }^{28}$

Most importantly, the government eliminated the tax on inputs imported by by assembly industries. This enabled local entrepreneurs to partner with multinational corporations and open manufacturing plants. Haiti was home to

25. Gerald de Santillana, Memo (7 January 1972), IAAR, box 18: "74-D-495: Pol. 2, General Reports and Statistics, 1972," 4692659.

26. Leslie J.R. Péan, Haïti: économie politique de la corruption, vol. 4, L'ensauvagement macoute et ses conséquences (Paris: G.P. Maisonneuve et Larose, 2007), 265-67. Péan also claims that Apaid was involved in a conspiracy to overthrow François Duvalier.

27. Jean-Robert Estimé, "International Sub-Contracting: The Case of Haiti" (Paris: Organisation de Coopération et de Développement Economiques, 1978), 21. Also see "The Economy: An Overview," Haïti Business (April-June 1981): 510; Jean-Robert Estimé with Robert Alexander (3 June 1971), Robert Jackson Alexander Papers (RJAP), box 8: "Haiti: Observations and Interviews, 1971," 14. Archibald Stevens Alexander Library, Rutgers University, New Brunswick, New Jersey.

28. Law (18 July 1974), in Le Moniteur (26 September 1974): 1. 
only 50 assembly plants in 1970 . By 1980 , however, it would have 200 . "Usually these plants are set up by a Haitian who is already in some other line of business," explained Raymond Reyes, a Belizean who worked at the Banque Royale du Canada in Port-au-Prince ${ }^{29}$ Corporate executives would spontaneously show up at the Banque, and Reyes would introduce them to Haitians who were interested in a partnership. While about 30 percent of the assembly plants in Haiti were wholly owned by multinationals, most were at least partially owned by Haitians. ${ }^{30}$ For example, André Apaid partially owned International Industries S.A, a company that stitched undergarments. He was also a partial owner of Industries National Réunies S.A., which assembled clothing and various plastic products (Fig. 21). ${ }^{31}$

The government might have appeased the business community had a crisis in the world economy not interrupted its overtures. In 1973, nine Arab nations imposed an oil embargo on the US and its closest allies. As a result, oil

29. Raymond Reyes with Robert Alexander (4 June 1972), RJAP, box 8: "Haiti: Observations and Interviews, 1971," 14.

30. Joseph Grunwald, Leslie Delatour, and Carl Voltaire, "Foreign Assembly in Haiti," in The Global Factory: Foreign Assembly in International Trade (Washington, D.C.: Brookings Institution, 1984), 187. Also see Monique P. Garrity, "The Assembly Industries in Haiti: Causes and Effects," Journal of Caribbean Studies 2, no. 1 (Spring 1981): 25-37; Gino Lofredo, "Transnational Sub-Contracting: An Assessment of the Impact of Export-Oriented Assembly Industries on Social and Economic Development in Haiti" (1980), BDCO, box 26: 4049010.

31. Curtis Hough, Memo on André Apaid (13 September 1963), ECGR, box 51: "560: Labor Affairs," 1719625. 


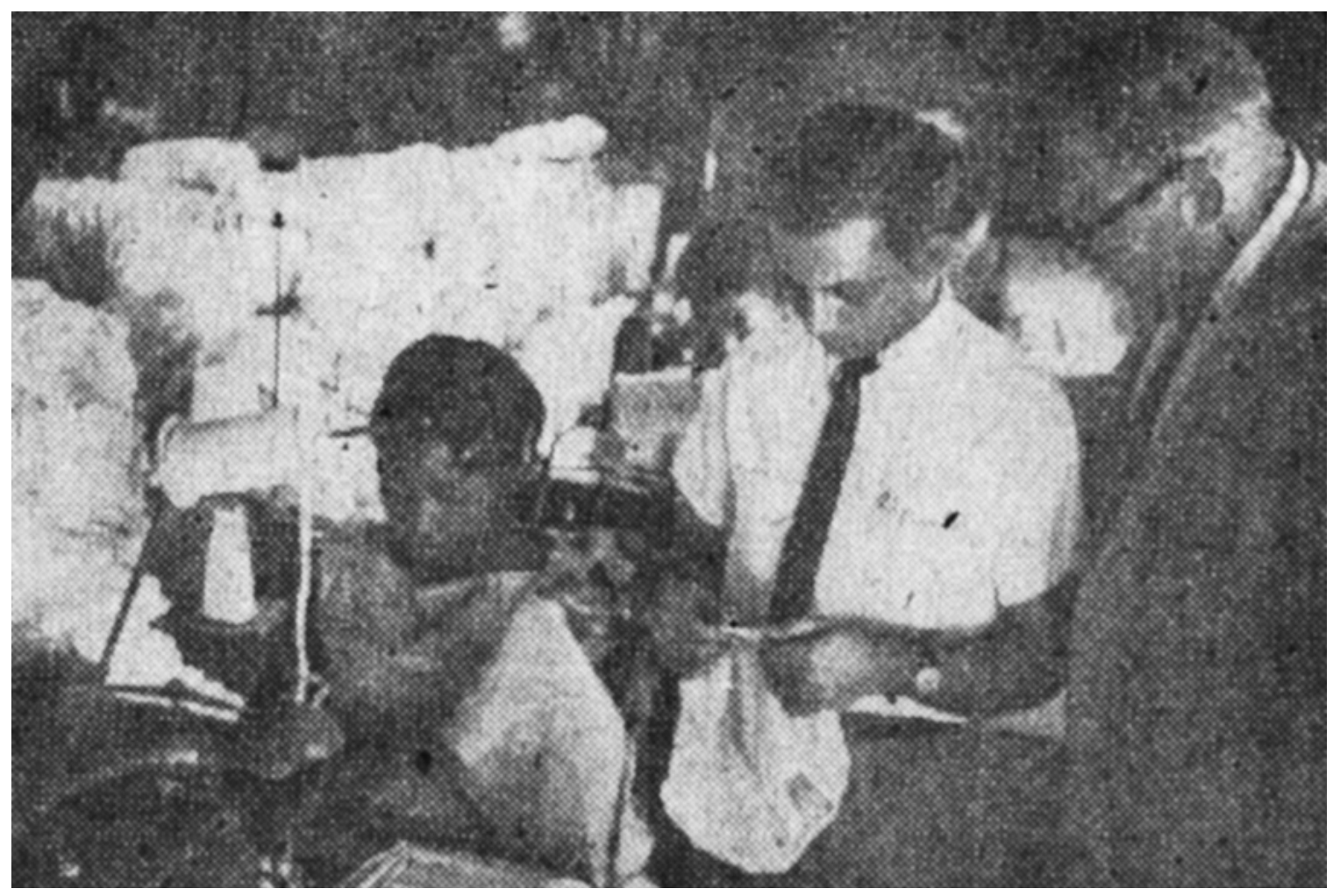

Fig. 21 André Apaid (center), Haitian Businessman. Photo by Bernard Diederich. From: Haiti Sun (21 January 1962): 1. Reproduced with permission.

became scarce; energy prices nearly quadrupled; and because every industry consumes energy, commodity prices skyrocketed. ${ }^{32}$ Duvalier's best technician, Serge Fourcand, tried to contain inflation with price controls. When the business community protested, Fourcand threatened to say it was anti-government. "I would not have done this sort of coercion last year," he explained. Given the

32. As calculated by the International Monetary Fund (IMF) in its International Financial Statistics Yearbook, vol. 33 (1980), 208-209, commodity prices in Haiti increased by 39.3 percent between 1972 and 1975, even with price controls in place. Meanwhile, the government's annual energy bill increased by six to seven million US dollars. 
circumstances, however, business owners "will have to tighten their belts, like it or not."33

In addition to price controls, the business community had to deal with a minimum daily wage, which the government increased to 6.50 Gourdes to address a 15 percent spike in the cost of living. ${ }^{34}$ Fourcand hinted that "some in the government proposed raising the minimum wage immediately to $1.40 \mathrm{US}$ dollars." While this would have helped the Haitian people, Fourcand believed that "a 40 percent increase [in] one swoop would be unfair to the foreign investors and other businessmen who have made plans... based on the 1 US dollar rate." ${ }^{35}$

Squeezed by the minimum wage and Fourcand's price controls, businesses cut back on production, which led to a whole new crisis, as shortages provoked widespread resentment. Fourcand noted how vegetable oil was especially scarce. The industry was an oligopoly, led by the Brandts and the Madsens, who had pressured the Duvaliers to withhold new concessions. ${ }^{36}$

33. Serge Fourcand and Gerald de Santillana, Memo (4 February 1974), IAAR, box 24: "75-D-474: Memorandum of Conversation, 1974," 4692770.

34. Jean-Claude Duvalier, Address (22 January 1974), in Discours et messages, vol. 2 (Port-au-Prince: Henri Deschamps, 1979), 111-14. Also see "Coût de la vie," Bulletin trimestriel de statistique de l'Institut Haïtien de Statistique, no. 93 (1974).

35. Paraphrased in Santillana, Memo (11 January 1974).

36. John Burke, Memo (10 January 1974), IAAR, box 24: "75-D-474: Fn. 9, Foreign Investment, 1974," 4692763. According to Burke, the Brandts and the Madsens pressed the Haitian government to revoke a concession that it had given to the Minnesota company, I.S. Joseph, to open a soybean-oil plant in 
Without competition, it had become inefficient and could barely keep up with demand. Convinced that businesses had hidden the oil to increase the price, Macoutes raided storehouses throughout the country. When the spectacle ended, Fourcand "point[ed] out to the president that no significant stocks of 'hoarded' cooking oil had been found." ${ }^{37}$ Nevertheless, top Duvalierists, like General Breton Claude, seized the opportunity to orchestrate a black market that specialized in commodities like vegetable oil. ${ }^{38}$

The crisis only worsened between 1975 and 1980. In an ill-conceived attempt to prevent shortages, the government printed money to invest in new state enterprises, such as the Entreprise Nationale des Oléagineux (ENAOL), a cooking oil plant. As the government printed more currency, however, each note became less valuable. Concerned that entrepreneurs might pay them back with worthless Gourdes, banks increased the interest rate on business loans and let money pile up in their vaults. ${ }^{39}$

Haiti. Also see by Robert W. Beckham and Henri Bayard, Memo (6 March 1974), same location.

37. Santillana, Memo (4 February 1974).

38. Gerald de Santillana, Memos (25 March and 3 May 1974), IAAR, box 24 : "75-D-474: Memorandum of Conversation, 1974," 4692770. Also see Fritz Deshommes, Vie chère et politique économique en Haïti (Port-au-Prince: Imp. II, 1992), 157-90.

39. André Lubin, "Déficits budgetaires, inflation et activité économique en Haïti, 1975/6 à 1989/90," Bulletin Semestriel de la Banque de la République d'Haïti, no. 22 (April-September 1991): 69. Also see Marie-Flore Bordes Jocelyn, "Evolution du credit dans l'économie haïtienne," BRH magazine, no. 16 (September 1991): 76. 
In 1980, André Apaid summoned the business community to take collective action. They created the Association des Industries d'Haïti (ADIH). In response to the liquidity crisis, ADIH organized an industrial development bank, the Société Financière Haïtienne de Développement (SFHD). The Société was led by Apaid and Robert Duval, two businessmen whom the Duvaliers had previously imprisoned. The board also included Raymond Roy, whose steel business, Haïti Métal, was ravaged by contraband, and Marcel Léger, a banker who worked closely with the Brandts. ${ }^{40}$ The Reagan Administration applauded ADIH and subsidized SFHD with 5 million US dollars. The Société was a "remarkable... private sector operation!" exclaimed Ambassador Ernest Preeg. ${ }^{41}$

The business community, now well organized, supported a bloodless revolution by local technicians. In 1981, the IMF persuaded Duvalier to entrust the Ministère des Finances and the Banque Nationale to Marc Bazin, a Haitian specialist, previously employed by the World Bank. Bazin recruited Guy Malary of ADIH and Marcel Léger of SFHD. He also appointed economists Leslie Delatour and Hervé Denis as his personal assistants. On 8 August 1981, Duvalier reluctantly announced the group's economic recovery plan. It included "the rigorous management of public finances, fiscal and budgetary discipline... the

40. “SFHD vers l'envol," L'Information (21 April 1983): 9.

41. Ernest $\mathrm{H}$. Preeg, Haiti and the CBI: A Time of Change and Opportunity (Miami: University of Miami, Institute of Interamerican Studies, 1985), 30. 
promotion of exports, and the defense of national industry" against the black market. ${ }^{42}$

Bazin worked zealously to clean up the economy. His team policed contraband and audited the Banque Nationale. ${ }^{43}$ "Beginning at least as early as 1975," Delatour explained, "Duvalier [had] put in place a system by virtue of which non-budgeted accounts were created and augmented by funds from the public treasury and revenues from public institutions." ${ }^{44}$ These institutions included state enterprises, such as Caribbean Mills, which the government had purchased and renamed Minoterie d'Haïti. Delatour discovered how "Duvalier maintained a private checkbook with which he personally drew checks on nonbudgeted accounts." According to Delatour, the president had embezzled at least 70 million US dollars.

One month into his appointment, Bazin exposed the government's best kept secret. The Duvaliers had given a Lebanese consortium, the Zubeidi Trading Company, 3.9 billion US dollars in government promissory notes to sell

42. Jean-Claude Duvalier, Address (8 August 1981), Princeton University Library, Rare Book Collection, Princeton, New Jersey. According to Preeg, Duvalier's speech was written by Bazin and company.

43. "Mr. Clean Scours a Corrupt Elite," Newsweek (10 May 1982): 13.

44. Leslie Delatour, Affidavit (16 January 1987), submitted to the New York Supreme Court as evidence in Republic of Haiti v. Jean-Claude Duvalier et al. (February 1987), BDCO, box 46: 5109038. Also see Onill Millet and François St. Fluer, Report (Port-au-Prince: Banque Nationale, 1987), Amy Wilentz Haiti Material (AWHM), box 1: "Economic Crimes." New York Public Library, Schomburg Center for Research in Black Culture, Manuscripts, Archives, and Rare Books Division. 
overseas. When Bazin canceled the notes, the media anointed him "Mr. Clean." Preeg noticed how business owners spoke openly about "how nice it would be to see Bazin in the palace" in place of Duvalier. ${ }^{46}$

Bazin appropriated the conservative discourse of the New Right, which associated personal initiative with masculinity. ${ }^{47}$ Haitian journalist Aubelin Jolicoeur observed how Bazin "dominates his passions." ${ }^{\text {48 }}$ When Jolicoeur asked why one man would take on such a heavy burden, Bazin quoted Reagan. "If not us, who?" Bazin replied. "If not now, when?" He insisted that Haitians work hard to build a robust economy. He made an exception, however, when the Reagan Administration gave him 350 million US dollars in assistance. "We, like Reagan, believe in the magic [of the market]!" he exclaimed. ${ }^{49}$

Threatened by Bazin's bravado, Duvalier responded violently, which only validated the position of the New Right—-that government is tyranny and an

45. "Des grands maux du pays courageusement révélés et dénonés par le Ministre des Finances M. Bazin," Le Matin (4 March 1982): 1.

46. Preeg, 35.

47. Jan Hanska analyzes this discourse in Reagan's Mythical America: Storytelling as Political Leadership (New York: Palgrave Macmillan, 2012). Also see Toby Glenn Bates, The Reagan Rhetoric: History and Memory in 1980s America (DeKalb: Northern Illinois University Press, 2011); Michael Weiler and W. Barnett Pearce, eds., Reagan and Public Discourse in America (Tuscaloosa: University of Alabama Press, 1992).

48. Marc Bazin with Aubelin Jolicoeur, Le Petit Samedi Soir (13-19 March 1982), in Dossier de presse: Marc L. Bazin (Port-au-Prince: Mouvement pour Instaurer la Démocratie en Haïti, 1987), 12.

49. "Le Ministre Bazin fail le point sur la situation économique du pays," Le Nouveau Monde (4 March 1982), in Dossier de presse: Marc L. Bazin, 15. 
obstacle to growth. In July 1982, he sacked Bazin, who retreated to the World Bank. In a misguided attempt to bully the business community back into submission, the Macoutes arrested his assistants, who had supposedly denounced the government in a memo to the IMF. A top Duvalierist, Roger Lafontant, shaved Delatour's head and beat Denis nearly to death. ${ }^{50}$

Duvalier's crackdown resembled a scene in The Road to Serfdom by Friedrich Hayek, who taught philosophy at the University of Chicago. Like the Nazis and the Soviets, whom Hayek detested, the Duvaliers tried to plan the economy with concessions, price controls, and state enterprises. "When economic power is centralized as an instrument of political power," Hayek warned, the individual becomes a "slave" and "opposition means death." Delatour and Denis experienced what Hayek described as the "government whip."

The Reagan Administration intervened to show Haiti a path to prosperity without the Duvaliers. On 24 February 1982, it unveiled the "Caribbean Basin Initiative" (CBI). Modeled largely on "Operation Bootstrap" in Puerto Rico, the $\mathrm{CBI}$ would combine 350 million US dollars in assistance to the Caribbean and Central America with tax exemptions on certain exports to the US. ${ }^{52}$ It was an obvious

50. Gabriel Verret to Bernard Diederich (22 January 2006), BDCO, box 14: 2064015. Also see Diederich, L'héritier: Jean-Claude Duvalier, 1971-1986 (Portau-Prince: Henri Deschamps, 2011), 255-57; Daniel-Gérard Rouzier, Le pouvoir des idées (Port-au-Prince: Communication Plus, 2002), 155-57.

51. Hayek, The Road to Serfdom, 41-42.

52. As explained by Richard Weisskoff in Factories and Food Stamps: The Puerto Rico Model of Development (Baltimore: Johns Hopkins University Press, 
ploy to isolate the Marxist regimes in Nicaragua, Cuba, and Grenada. ${ }^{53}$

Nevertheless, Reagan promised that it would help nations like Haiti "make use of the magic of the marketplace...to earn their own way toward self-sustaining growth. ${ }^{54}$ Backed by multinationals and the Miami-based corporate lobbying group, Caribbean-Central American Action (C-CAA), the Reagan Administration encouraged the Caribbean to specialize in manufacturing and import America's agricultural surplus. ${ }^{55}$

The CBI elicited a mixed response. Led by Serge Fourcand, many Duvalierists opposed it. They warned that it would create an unequal, exploitative relationship between the US and Haiti. ${ }^{56}$ The idea that ordinary Haitians would pull themselves up by the bootstraps, however, had immense appeal in a country

1985), Operation Bootstrap was a plan introduced by the US government in 1948 to industrialize Puerto Rico.

53. Devanand J. Ramnarine, "The Political Logic of the CBI," in Imperial Power and Regional Trade: The Caribbean Basin Initiative, eds. Abigail B. Bakan, David Cox, and Colin Leys (Waterloo: Wilfred Laurier University Press, 1993), 11-44.

54. Ronald Reagan, "Remarks on the CBI to the Permanent Council of the OAS" (24 February 1982), in The Public Papers of the Presidents of the United States, vol. 2 (Washington, D.C.: Government Printing Office, 1983), 210-15.

55. Ronald Cox analyzes the C-CAA position on Haiti in "Private Interests and US Foreign Policy in Haiti and the Caribbean Basin," in Contested Social Orders and International Politics, ed. David Skidmore (Nashville: Vanderbilt University Press, 1997), 187-207. Also see "Haiti-The New Frontier," Haiti Times 1, no. 2 (1984): 1-2, BDCO, box 26: 4049017.

56. Serge Fourcand, "La CBI et le système économique mondial" and "Le système et politique nationale du dévéloppement," L'Information (27 April-2 May 1984): 14-20. 
where business owners associated central planning with tyranny. ${ }^{57}$ According to the University of Chicago economist, George Shultz, whom Reagan appointed as Secretary of State, the only alternative was "the Cuba solution." 58

The Governor of Florida, Bob Graham, energetically supported the CBl's application to Haiti. Between 1971 and 1981, as many as 45,000 Haitians refugees had fled to Florida aboard tiny boats. ${ }^{59}$ Mistakenly convinced that Haitian "boat people" had introduced AIDS, Floridians implored Graham to contain them. In response, Graham asked the Florida business community to invest in Haiti. ${ }^{60}$ With Florida's help, he theorized, local businesses could employ more people, who would opt to stay in Haiti.

Supported by Reagan and Graham, the business community deemed the Duvaliers unnecessary and abandoned them in their time of need. By 1985, shortages had led to famine, and protests had broken out in Gonaïves. Galvanized by the Catholic Church, students were organizing a movement for democracy. Pressed to pick a side, ADIH secretly convened and chose

57. "Businessmen Must Take Advantage of CBI," ADIHGRAM 1, no. 12 (15 May 1985): 17-18, BDCO, box 26: 4049018. Also see André Apaid, "Remarque du Président de l'ADIH," L'Information (27 April-2 May 1984): 12.

58. George Shultz, Address (13 April 1983), in Current Policy, no. 477 (April 1983): 2.

59. Josh DeWind and David Kinley III, Aiding Migration: The Impact of International Development Assistance on Haiti (Boulder: Westview Press, 1988), 9.

60. "Report of the Florida Mission to Haiti," Haïti Business (January-March 1982): 14-25. 
democracy. In a public statement, ADIH explained how "government intervention" had created a "climate of fear and tension" that was "effecting investment in Haiti." ${ }^{61}$ It bemoaned how "some foreign firms have already made the decision to either avoid or withdraw operations." On 2 February 1986, Apaid suspended work in his assembly plants to participate in a general strike. The "rotten regime" needed "one last push," Apaid sneered. It was time to "take initiative."62

Shocked by ADIH's announcement, the Duvaliers tried in vain to win back the business community. "The fact that members of ADIH... joined the movement of popular claims was certainly significant," the Ministre des Affaires Etrangères, Georges Salomon, solemnly acknowledged. ${ }^{63}$ Salomon suspected that "the press note of ADIH was written by certain people who are closely linked to the American embassy, and imposed on the other members" by Apaid. In response, the Duvaliers composed a "lettre de solidarité" and beseeched the business community to endorse it. The lettre asked the government to "take every reasonable measure to suppress the subversive menace," but no one wanted to sign it. ${ }^{64}$

61. ADIH "Press Note," Haiti Times (15 January 1986): 8, BDCO, box 38: 5049008.

62. André Apaid with Bernard Diederich (February 1986), BDCO, box 38 : 5043001.

63. Georges Salomon, Unpublished Testimony (no date), 12, AWHM, box 1: "Salomon."

64. "Lettre de solidarité des membres de la Chambre de Commerce d'Haïti au Président Jean-Claude Duvalier," BDCO, box 26: 4049002. According to Bernard 
Once ADIH had broken ties with the Duvaliers, the Reagan Administration was quick to do the same and the dynasty instantaneously crumbled. On 3 February, Shultz appearanced on the TV show, "Good Morning America," and advocated "democratic process" in Haiti. ${ }^{65}$ In response, many Haitians adopted the US flag. Shultz "gave us some hope," one businessman explained. ${ }^{66}$ Overwhelmed by protesters, Salomon asked Shultz to dispatch a plane to take the Duvaliers into exile. "I checked directly with President Reagan," Shultz recalled. ${ }^{67}$ "He agreed." At 3:47 am on 7 February, the Duvaliers boarded a US C-141 to France and a new Conseil National de Gouvernement (CNG), hand picked by Jean-Claude, replaced the 30 -year dynasty. ${ }^{68}$

\section{Dr. Harberger Goes to Haiti}

When the business community endorsed the revolution that ousted the Duvaliers, it saved its credibility and secured a privileged role in the new

Diederich, the petition was composed by Jean-Claude's father-in-law, Ernest Bennett, not HAMCHAM, as the title states.

65. George P. Shultz, Turmoil and Triumph: My Years as Secretary of State (New York: Charles Scribner's Sons, 1993), 620-23.

66. Bernard Diederich, Report (6 February 1986), BDCO, box 37: 5011001.

67. Shultz, Turmoil and Triumph, 622.

68. It is unknown why Duvalier chose Namphy. Salomon claimed that JeanClaude "told me to note on a piece of paper the composition of the new government to succeed him," and "he immediately appointed [Lieutenant] General Henri Namphy." Elizabeth Abbott supports Salomon's story but says Namphy had secretly coordinated the military's insubordination. 
government. Led by Lieutenant-General Henri Namphy, the CNG also included Colonel Williams Régala, Colonel Prosper Avril, and two civilians, Gérard Gourgue and Alix Cinéas. It appointed Marcel Léger as Ministre des Finances and asked Apaid to lead a new committee that would support private enterprises. ${ }^{69}$

As provisional president, Namphy accommodated the New Right to obtain Reagan's support. In a televised speech on 25 February 1986, he announced his intention to promote democracy and markets. In French, the language of the Haitian elite, he vowed to "eliminat[e...] monopolies in the manufacturing sector" and "stimulat[e...] competition within a system of free enterprise." ${ }^{70} \mathrm{He}$ also promised to institute new democratic institutions "by decree." In the meantime, however, "all measures needed to support and encourage private sector initiatives." Otherwise, the Haitian "economy will continue to stagnate," and "sharp social and political tensions" would undermine any step toward democracy. ${ }^{71}$

69. Decree (4 June 1986), in Lois et actes du Conseil National de Gouvernement du 7 février 1986 au 7 février 1988, vol. 3 (Port-au-Prince: Imp. de l'Etat, 1988), 132-34. Also see Apaid with Diederich (February 1986).

70. Henri Namphy, Address in French (25 February 1986), in Discours et messages: 7 février 1987 à 7 février 1987 (Port-au-Prince: Henri Deschamps, 1987), 15-16.

71. Henri Namphy, "Haïti: Président Henri Namphy," Journal of Caribbean Studies 6, no. 1 (1987): 75-82. 
Namphy's proclamation was highly praised by Marc Bazin. "We are lucky [the CNG] is led by [Lieutenant] General Henri Namphy," Bazin declared. ${ }^{72}$ "Namphy is a man of great merit!" Bazin organized his own political party, the Mouvement pour Instaurer la Démocratie en Haïti (MIDH), and pledged to uphold Namphy's plan. ${ }^{73} \mathrm{MIDH}$ advocated "the promotion of a market economy as a prerequisite to an open political system, in which a dynamic private sector can serve as an effective counterweight to the power of the state. ${ }^{74}$ The business community welcomed Bazin back to Haiti. Nearly 3,000 supporters greeted him upon arrival. They printed t-shirts that read, "Bazin cé nèg prop, cé li nou vlé!"75 Newspapers hailed, "Bienvenue Mr. Clean," the "citoyen ayant la crédibilité nationale et internationale!"76

While the business community embraced Bazin and Namphy, not everyone understood what they hoped to accomplish. Namphy presented his vision a second time, in Kreyòl, but strategically omitted the section on neoliberalism. "We must give the people this explanation today because the

72. Marc Bazin with Michel Faure, Libération (13 February 1986), in Dossier de presse: Marc L. Bazin, 44.

73. "Interview: Marc Bazin," Le Point (5 May 1986), in Dossier de presse: Marc L. Bazin, 65.

74. "Définit le 'MIDH' qu'il a fondé et qui s'affirmera en Haïti," Le Matin (26 March 1986): 1, 6. Also see Marc Bazin with Frantz Duval and Jobnel Pierre, D’où viennent les idées de Marc L. Bazin? (Port-au-Prince: Imp. II, 2008), 61.

75. "St-Marc a accueilli Marc Bazin en triomphateur," Le Nouvelliste (7 April 1986), in Dossier de presse: Marc L. Bazin, 54.

76. "Bienvenue Mr. Clean," Le Matin (1 April 1986): 5. 
people deserve an explanation, too!" he proclaimed. ${ }^{77}$ Rather than present his economic policy, however, Namphy scolded vigilantes, who wished to punish the Macoutes. The business community expressed concern that Namphy intentionally misled the Haitian people. In a private report, ADIH and the HaitianAmerican Chamber of Commerce and Industry (HAMCHAM) lamented how his "message differ[ed] from one language to the other."

Nevertheless, local technicians pressed Namphy to implement neoliberalism. Léger insisted that Namphy "come up with a rigorous new [plan]. ${ }^{79}$ Hence, Namphy turned to Arnold Harberger, an economist at the University of Chicago who had previously advised General Augusto Pinochet in Chile. ${ }^{80}$ Presumably, Harberger endorsed Haiti's own "Chicago Boy," Leslie Delatour, because on 21 April 1986, Namphy appointed Delatour as Ministre des Finances.

77. Henri Namphy, Address in Kreyòl (25 February 1986), in Discourse et messages, 18-22.

78. Alliance du Secteur Privé, "Press Review Report" (6 October 1986), BDCO, box 38: 5049007.

79. "Le Ministre des Finances presents sa semission," Le Matin (19-21 April 1986): 1 .

80. Bernard Diederich, Report (23 April 1986), BDCO, box 38: 5011003. In the book, The Internationalization of Palace Wars: Lawyers, Economists, and the Contest to Transform Latin American States (Chicago: University of Chicago Press, 2002), Yves Dezalay and Bryant Garth describe Friedman and Harberger as "super salespeople" who "vulgarized" and "disseminated" neoliberalism "as a miracle remedy for the ills of the economy." Also see Juan Gabriel Valdés, Pinochet's Economists: The Chicago School in Chile (New York: Cambridge University Press, 1995). 
Delatour's mantra, that "socialism doesn't work," was in line with the "Chicago School," led by economist Milton Friedman. The Chicago School opposed government intervention in the economy, as advocated by John Maynard Keynes. It believed that any attempt to manipulate the economy would upset the delicate equilibrium between supply and demand. ${ }^{81}$ "If the key to economic development was government taking everything over and spending money," Delatour joked, "then everybody should have been developed by now!"82

Nine days into his appointment, Delatour secretly met with USAID to come up with a plan to build a new economy based on assembly industries and corporate partnerships. Delatour told his US counterparts, Linda Morse and James Walker, that he wanted to keep wages as low as possible. The cost of living, however, was too high. Like Milton Friedman, Delatour believed that "shock treatment" was the only way to contain inflation. ${ }^{83} \mathrm{He}$ would thus implement a "balanced budget, with expenditures reduced to 75 million Gourdes per month and no central bank financing.. ${ }^{84}$ Excess liquidity in private banks "will

81. Johan Van Overtveldt, The Chicago School (Chicago: Agate, 2007), 6-12.

82. Delatour in Reason, 33-35.

83. Naomi Klein explains how Milton Friedman envisioned liberalization as electro-shock therapy in The Shock Doctrine: The Rise of Disaster Capitalism (New York: Macmillan, 2007).

84. Linda Morse and James Walker, Memo (7 May 1986), in Fritz Deshommes, Haïti: le nation écartelée entre "plan américain" et projet national (Port-au-Prince: Editions Cahiers Universitaires, 2006). Also see Georges Henry Fils, "Excédent de liquidité et gesion du passif-dépôts des banques" and Nagib Handal, Jr., "Marché monétaire et politique monétaires en Haïti," Bulletin trimestriel de conjoncture de la Ministère de l'Economie et des Finances, no. 2 (1987). 
be mopped up with increased reserve requirements," Delatour explained. The government would then slash protective tariffs, revoke monopolistic concessions, and privatize state enterprises. This "will be very painful in the short run," Morse and Walker warned.

Delatour's colleagues were indeed shocked when they learned about his plan. Outside the Ministère des Finances and the Banque Nationale, employees held up placards that exclaimed, "return from where you came!"85 When Delatour tried to replace the Directeur de la Banque Nationale, Onill Millet, with a loyal technician named Carl Voltaire, Millet barricaded himself inside the building. His supporters circulated a petition, protesting Voltaire's appointment. ${ }^{86}$ When Millet denounced Delatour on television, however, the military surrounded the Banque and demanded that Millet step down.

Delatour's opponents were livid when they heard about the secret meeting with Morse and Walker. Emboldened by Gérard Gourgue, who quit the CNG to protest Namphy's unwillingness to prosecute Macoutes, they took to the streets and blocked the nation's highways with debris. When the military tried to remove the obstacles, protesters shot and killed a sergeant. ${ }^{87}$

85. Bernard Diederich, Report (24 April 1986), BDCO, box 38: 5011003.

86. "Lettre des employés de la BRH" and "En marge de l'affaire DelatourVoltaire-BRH," Le Courrier (25 April-2 May 1986): 5-7. Also see "Le gouverneur du grand argentier contesté par les cadres de la BRH," Le Petit Samedi Soir (26 April-2 May 1986); "René Théodore, le communiste opine autour du confil Delatour-Voltaire-Millet," Libération (17-24 May 1986): 1.

87. Bernard Diederich, Reports (11 and 12 June 1986), BDCO, box 38 : 5011004. 
The business community tried to keep everyone calm. ADIH warned that "savage strikes and disorder in the streets have already cost the country more than 12,000 jobs," and "should the atmosphere of insecurity persist, it can only lead to a dramatic increase in unemployment." ${ }^{88}$ Apaid promised that "once peace has returned to the streets," Haiti would "not only recover the jobs lost but also create new ones."

The US government also intervened. As Voltaire increased reserve rates to 38 percent, USAID replaced the Haitian Gourdes with 88 million US dollars, preventing a recession. ${ }^{89}$ Meanwhile, Shultz invited the corporate lobbying group, C-CAA, and 60 corporate executives, including David Miller of Eden Toys and Frederic Brooks of MacGregor Sporting Goods, to the White House, where he encouraged them to invest in Haiti. ${ }^{90}$ Shultz lionized Delatour as a "pragmatic, dry cut" technician, "well educated" by "the University of Chicago." ${ }^{91} \mathrm{He}$ presented the audience with investment opportunities and vowed to contain Haitian syndicalism. "With USG backing," he explained, the American Federation of Labor and Congress of Industrial Organizations (AFL-CIO) had "expanded its

88. ADIH, Press Statement (10 June 1986), BDCO, box 38: 5049008.

89. USAID, "Mission to Haiti: Fact Sheet" (March 1986), BDCO, box 46: 5109030.

90. "Briefing for US Businessmen in Haiti: Invited Guests" (1986), Donald Danner Files, 1985-1988 (DDFS), Serial No. OA 14887: "Haiti, Caribbean Basin Initiative," 1. Ronald Reagan Library, Simi Valley, California.

91. "White House Briefing on Haiti to US CEOs" (13 June 1986), same location as the previous citation. 
support for the moderate Federation of Union Workers" in Haiti. The AFL-CIO would "channel" and neutralize the "spontaneous development of trade unions."92

On 15 August 1986, Shultz went to Haiti to endorse the CNG and support the local business community. Welcomed by Namphy, who promised to implement any policy needed to improve the economy, Shultz reiterated that "sustained economic growth... cannot succeed without a productive private sector." ${ }^{93}$ Shultz gave Apaid 7.7 million US dollars to create the Center for the Promotion of Investment and Exports (PROMINEX) and advertise Haiti as the hemisphere's best kept secret. ${ }^{94}$ "Under the CBI," he stated, the US government would "guarantee access levels for certain apparel products which offer a good prospect for export expansion and concomitant job creation." Lastly, Shultz met with Delatour, who signed an agreement to increase US aid by 10 million US dollars. ${ }^{95}$

Shultz's visit, however, upset many Haitians. A broadcast entitled, "Good Morning Mr. Shultz," criticized how the Secretary of State treated Haiti like a "prostitute." It also condemned his promise to provide "security assistance" to

92. Ibid. Also see Michel Soukar's commentary on the AFL-CIO in Seize ans de lutte pour un pays normal (Port-au-Prince: Editions SCOLHA, 1987), 50-51.

93. George Shultz, Statement in USIS, Communiqué de presse, no. 86/62 (15 August 1986), BDCO, box 45: 5109011.

94. USIS, Communiqué de presse, no. 86/60. Also see "Schedule of Events," BDCO, box 45: 5109011.

95. "Les deux accords de dons du 15 août," Le Matin (22-25 August 1986): 1.

96. "Good Morning Mr. Shultz," quoted in "Radiographie d'une visite," Le Matin (27 August 1986): 1, 5. 
the military. Only seven months since they had waved US flags in opposition to the Duvaliers, Haitians marched on Port-au-Prince to denounce the Reagan Administration. "We want work!" they shouted. "Not guns!" They condemned racial discrimination in the US and expressed solidarity with the Sandinistas in Nicaragua. ${ }^{97}$

The protests quickly spread when ENAOL went bankrupt the very next month. Previously owned by the government, the cooking oil factory was a "dead duck," said Delatour. He would have shuttered the company immediately had the employees not begged him to let them turn it into a cooperative. ADIH did not think they would stand a chance against cheap imports and contraband. ${ }^{98}$ Nevertheless, Delatour declared, "I'm not giving them one bit of subsidy.... It is up to them to adjust from the old fiction to the new reality!"99 $T$ The cooperative soon collapsed, and ENAOL closed. ${ }^{100}$ Furious that Delatour did not help the workers, the media claimed that "[he wanted] to dance on [their] corpse[s]!"101

97. Bernard Diederich, Report (17 August 1986), BDCO, box 43: 5101006. Also see "George Shultz provoque tollé dans le rangs de l'opposition," Le Petit Samedi Soir (23-29 August 1986): 1.

98. Alliance du Secteur Privé, "Press Review Report" (11 August 1986), BDCO, box 38: 5049007.

99. Delatour in Reason, 34-35.

100. "Le Ministre Delatour a fermé Darbonne et ENAOL parce que nonrentables," Le Matin (30 September 1986): 1.

101. "Coup de tonnerre au Ministère des Finances" and "Faut-il accepter Delatour?" Miroir (July and August 1986). Also see "Il faut freiner M. Delatour" and "Les incohérences externs du discours Delatour," Le Courrier (30 May 1986, 31 May-6 June 1986). 
Hounded by the media, Namphy began to have second thoughts about democracy. He built new institutions to promote the political transition, but they were pathetically weak. The new provisional legislature, the Conseil Consulatif, could only make "suggestions and recommendations to the CNG." 102 Its only substantial responsibility was to organize an election in which the county would select an "Assemblée Constituante" to compose a new constitution. Skeptical that Namphy would accept a progressive constitution, however, only 5 percent of the population voted. ${ }^{103}$ Meanwhile, Namphy instituted a "Commissariat" to "support local solutions to regional problems." ${ }^{104} \mathrm{He}$ also summoned new provincial representatives to Port-au-Prince, but they could only make "recommendations" to the CNG. ${ }^{105}$

Less interested in democracy than markets, Namphy accompanied Delatour and Apaid to Miami, where they networked with multinationals. Escorted past Haitian-American protesters by the Miami-Dade County Police, Namphy attended the 10th Annual Conference on Trade, Investment, and Development in

102. Decree (27 June 1986), in Lois et actes du Conseil National de Gouvernement, vol. 1, 169-71.

103. Paul Dejean, Prélude à la liberté: panorama de la situation politique haïtienne après le 7 février 1986, du 15 août 1986 au 14 mars 1987 (Port-auPrince: Imp. Rodriguez, 1987), 38-39.

104. Henri Namphy, Address (11 August 1986), in Discours et messages, 111.

105. Namphy created the Conseils d'Administration des Sections Rurales (CASER) by Decree (26 June 1986), in Lois et actes du Conseil National de Gouvernement, vol. 1, 163-66. 


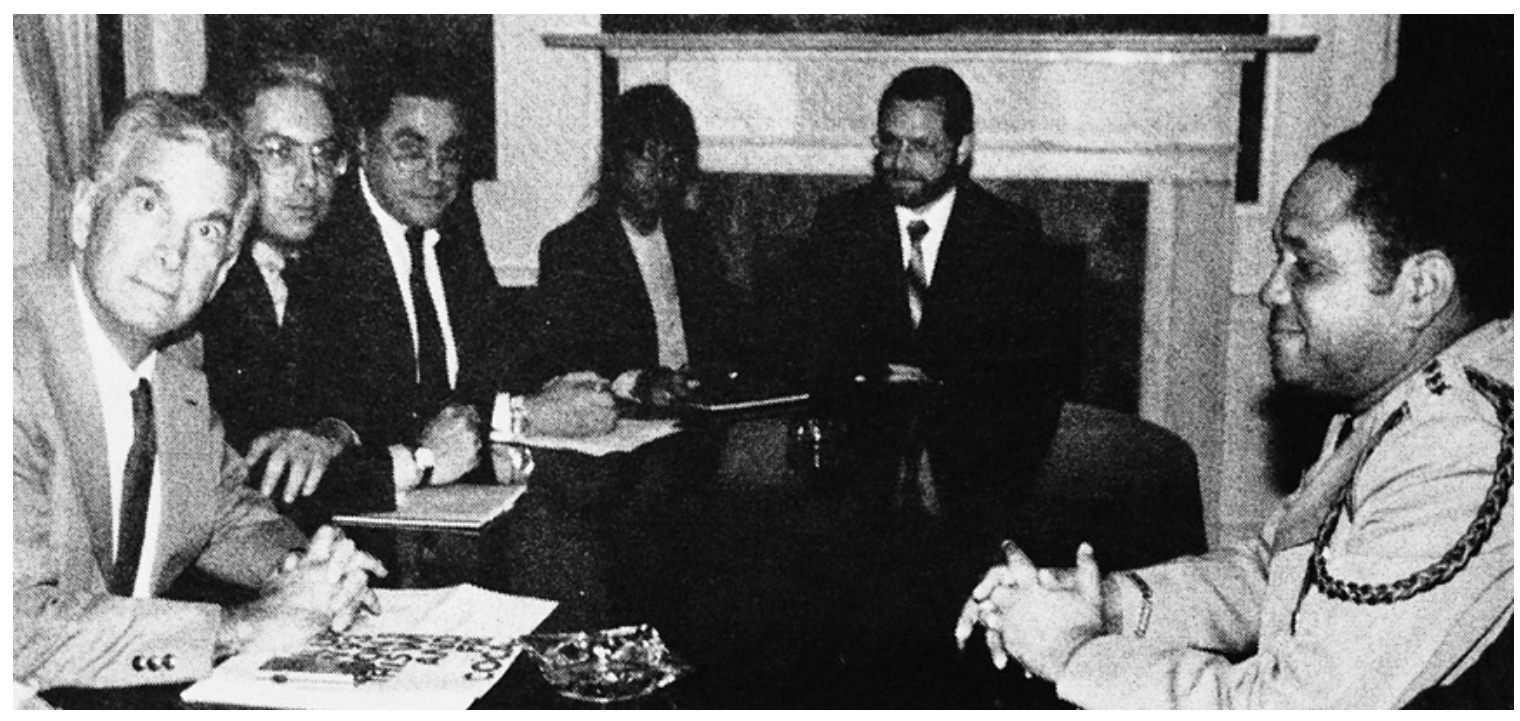

Fig. 22 Frederic Brooks, CEO of MacGregor Sporting Goods (far left) with Henri Namphy (far right), David Miller of Eden Toys (third from the left), Indira Jhappan of Caribbean-Central America Action (to Miller's left), and Joel Thebaux of PROMINEX (to Namphy's right). From: Caribbean Action, no. 2 (1987): 3. Reproduced with permission.

the Caribbean Basin, hosted by the C-CAA. ${ }^{106}$ The Governor of Florida, Bob Graham, the CEO of Eden Toys, David Miller, and the CEO of MacGregor Sporting Goods, Frederic Brooks, welcomed Namphy to Miami, and the General thanked them in a special address (Fig. 22). "[Haiti's] economic development policy seeks to take all appropriate measures to foster and sustain the initiative of the private sector," Namphy explained. ${ }^{107}$ Haiti would abandon "import substitution" and "protectionism." It would embrace its "comparative advantage"

106. Dan Sewell, Report (19 November 1986), BDCO, box 43: 5101008. Also see C-CAA, Program for the Miami Conference on the Caribbean (1986), same collection, box 38: 5049004

107. Henri Namphy, Address (19 November 1986), BDCO, box 45: 5109012. 


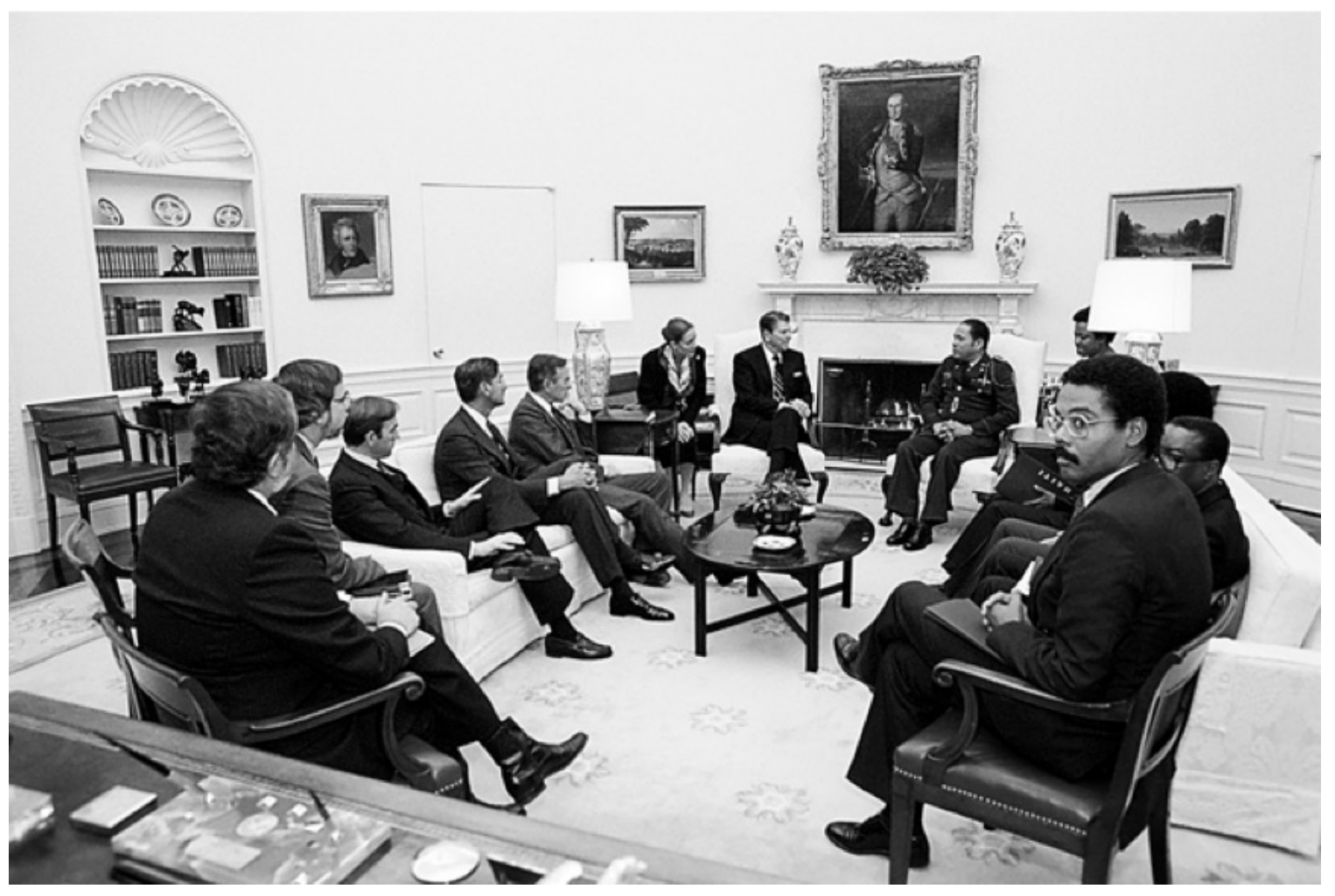

Fig. 23 Ronald Reagan (far back), President of the United States with Henri Namphy in the White House on 21 November 1986. Leslie Delatour (foreground, right) looks back toward the camera. From: White House Photographic Office Collection, Sheet No. 38083(02), Photo No. 1. Ronald W. Reagan Library, Simi Valley, California. Reproduced with permission.

to "break the bonds of poverty" and "transition from a reactionary dictatorship to a free society."

When the conference ended, Ronald Reagan invited Namphy and Delatour to Washington, D.C., where they met in the White House and discussed how the US government could lend a hand (Fig. 23). Reagan emphasized "the need to develop the Haitian private sector through foreign investment." ${ }^{\text {"108 }}$ In the

108. Ronald Reagan, Statement (21 November 1986), in The Public Papers of President Ronald W. Reagan, 1981-1989 (Washington, D.C.: National Archives and Records Administration, Office of the Federal Register, 2003). 
meantime, however, he would give Haiti an additional 25 million US dollars. He also vowed to invest in a new program to train Haitian entrepreneurs. Lastly, he praised Namphy's intention to organize a presidential election in 1987.

Delatour believed Haiti was on the right path. "[A] lot of people [were] suffering from higher prices," he explained, but now "inflation [is] down to zero." ${ }^{109}$ Capital flight "has stopped." The government's money "reserves [are] building up slowly," and "we... no longer have a system which is based on corruption." Delatour begged his fellow Haitians to be patient. Namphy promised them democracy, so "why do people say there is not going to be an election?" he asked.

The Day the Banks Stood Still

While Delatour trusted Namphy to promote democracy, the Haitian people were less naïve. Men and women, workers and peasants, united to oppose neoliberalism and demand elections. The movement began in 1986, when 30,000 women marched on Port-au-Prince, protesting gender inequality. ${ }^{110}$ Previously silenced by the Macoutes, women's organizations, such as Fanm Dayiti and the Comité de Liberation des Femmes Haïtiennes, were now active

109. Leslie Delatour with Bernard Diederich (February 1987), BDCO, box 38 : 5043002 .

110. N. Ricot, "Une marche de femmes sans precedent," Le Matin (5-7 April 1986): 1 . 
participants in civil society and criticized the new Ministre de Finance. ${ }^{111}$ Feminist economist Mireille Neptune Anglade lamented how multinational corporations "minimize[d assembly] costs by using mostly non-unionized women's labor.."112 This "savage exploitation," she bewailed, enriched a business class that was predominantly male.

The peasantry was next to join the protest movement. It complained about the merchants in Gonaïves, who were smuggling cheap, American rice into the country. Delatour praised the "drop in food prices as a social gain." He once stated that "rice is the only area where [Haiti] may hope to become self-sufficient" but now deemed it "stupid to ask the Haitian farmer to compete with the [subsidies] of the US government." ${ }^{113}$ Riled by Delatour's comments, the peasants blocked highways throughout the Artibonite Valley and attacked military patrols. ${ }^{114}$ Armed with machetes, they marched on Gonaïves until Namphy promised to suppress contraband.

111. Carolle Charles, "Gender and Politics in Contemporary Haiti: The Duvalierist State, Transnationalism and the Emergence of a New Feminism, 1980-1990," Feminist Studies 21, no. 1 (Spring 1995): 135-64.

112. Anglade, L'autre moitié du développement, 190-98.

113. Delatour with Diederich (February 1987). Also see Leslie Delatour and Paul Duret, "Rice in Haiti" (February 1984), 13.

114. "Découverte de trios cadavers dans la vallée rizicole de l'Artibonite," Le Matin (24-26 January 1987): 1. Also see Sandrine Fréguin and Sophie Devienn, "Libéralisation économique et marginalisation de la paysannerie en Haïti: le cas de l'arcahaie," Revue tiers monde 47, no. 187 (Jul.-Sep. 2006): 621-42. 
By April 1987, however, the black market had expanded exponentially. Overwhelmed by contraband, the Haytian-American Sugar Company (HASCO) abruptly closed. ${ }^{115}$ Mill workers, like Kénol Joseph, were distraught. In a misguided attempt to save the company, Joseph went to the US Consulate, seized an American woman, and threatened to kill her with a knife unless Delatour resigned. According to witnesses, he was shot and killed by police when he accidently stabbed the woman in the back. ${ }^{116}$

Joseph's death provoked widespread criticism. Led by Victor Benoit and Michel Soukar, Delatour's opponents spun an elaborate conspiracy theory, in which the Reagan Administration had brainwashed the Ministre des Finances to implement an "American Plan" that would undermine Haitian sovereignty. ${ }^{117}$ The media chimed in. "[Delatour] will destroy the national economy" and "subjugate the country to servitude!" it exclaimed. ${ }^{118}$ The US government insisted that "there

115. "Alors que les autorités concernées interdisent à la HASCO d'en produire" and "Grave crise dans l'industrie sucrière haïtienne," Le Matin (9 and 21 April 1987): 1.

116. Bernard Diederich, Report (13 May 1987), BDCO, box 38: 5011008.

117. "Le plan américain pour Haïti," Le Nouvelliste (26 November 1986): 1.

118. "Delatour, le paradoxe d'une mission" and "Lesly Delatour, la bête de gévaudan," Miroir (24 January 1987). Also see "L'effet néfaste du 'délatourisme,"' Le Petit Samedi Soir (16-22 May 1987); "Les recettes libérales FMI et Banque Mondiale: 'Chicago Boys' dans la marmite haïtienne et l'ingrédient dictature militaire," Impact (21 May 1986): 9. 
is no 'American Plan' for your country." 119 To the contrary, Delatour explained, the "Americans [had] adopted the 'Delatour Plan."”120

Animosity toward Delatour peaked when he demanded that Minoterie d'Haïti terminate a consultant named Yves Volel, who had supposedly denounced neoliberalism. Volel threatened to sue Delatour unless he apologize and pay 20 US cents as compensation. Delatour's lawyers barked that Minoterie "has no need for a political personality" like Volel, "whose behavior and actions are susceptible to grave prejudices!"121 When Volel used the spectacle to launch his campaign for the presidency, the military shot him in the head.

Disturbed by such violence, the Haitian people turned to the Catholic Church, which became increasingly hostile toward Namphy. Bishop Willy Romélus told Namphy to pick up and leave: "rache manyòk li yo!"122 He also supported a literacy campaign, "Misyon Alfa," that boldly stated: "we don't want the mòd ekonomi Delatou!"123

119. Brunson McKinley, Statement (8 December 1986), AWHM, box 1: "Embassy." Also see the commentary by USAID representative Gérald Zarr in Le Matin (9 September 1986): 1.

120. Delatour with Diederich (February 1987).

121. Jean Frantz Télasco, "Autopsie du process Yves Volel et Leslie Delatour" and "Leslie Delatour: césar en puissance," Le Petit Samedi Soir (14-20 February and 28 February-6 March 1987). 1.

122. "KNG, rache manyòk ou bay tè a blanch," Ayiti Ekran (September 1987):

123. Alfa Liberasyon: bilten Misyon Alfa (March 1987): 4, AWHM, box 1: "Alfa Mission." Also see Bernard Diederich, Report (17 March 1986), BDCO, box 38: 5011002. 
Meanwhile, in Jean-Rabel, a town in northwest Haiti, a priest named JeanMarie Vincent had organized a cooperative that denounced wealthy landowners. The cooperative, "Tét Ansanm," noted how "the peasantry has been exploited by the bourgeoisie [ever] since [the US invaded in] 1915." It taunted the elite. "Gwo boujwa! Ti boujwa!" it chanted. "If you're mad then come get us!"124

Led by Benoit and Soukar, 309 peasant, church, and women's organizations convened with a radical syndicate, the Centrale Autonome des Travailleurs Haïtiens (CATH), in January $1987 .{ }^{125}$ In a joint press statement, they condemned Delatour's vision as inadequate. The economy, they argued, should "serve the people," not multinational corporations. ${ }^{126}$ They appointed 58 representatives to a new "Komité Nasyonal Kongrés Mouvman Demokratik" (KONAKOM) and picked Gerrard Gourgue, the man who quit the CNG, as the organization's presidential candidate. ${ }^{127}$

124. Chante peyizan Jan-Rabel (N.P: N.p., 1987), 21, 32, BDCO, box 46: 5109056.

125. As explained by the US government in its "Labor Trends Report" (no date), AWHM, box 1: "Embassy," CATH included "six to eight unions registered with the government" and "about 20 unregistered unions."

126. Premye Kongrè Nasyonal Mouvman Demokratik, Statement (29 January 1987), BDCO, box 46: 5109040. Also see "Rezolisyon Premye Kongrè Nasyonal Mouvman Demokratik yo" (1 February 1987), in Haïti: la nation écartelée, 25564.

127. KONAKOM, Statement (1 February 1987), Haiti Dechoukaj Collection (HDCO), box 1: "Political Parties." New York Public Library, Schomburg Center for Research in Black Culture, Manuscripts, Archives, and Rare Books Division. 
Pressed by KONAKOM to promote democracy, the Assemblée Constituante composed a new constitution that decentralized presidential authority. Unveiled in March 1987, the constitution separated the military and the police; restored the Sénat and Chambres des Députés; and established new Conseils d'Administration de la Section Communale to govern the provinces. ${ }^{128}$ Most importantly, it put in place a Conseil Electoral Provisoire to "organize and control" elections with "total autonomy." 129

In June 1987, Namphy suspended the Conseil Electoral Provisoire and outlawed CATH, provoking a violent backlash. KONAKOM and CATH proclaimed that the "CNG exists to uphold Duvalierism.." ${ }^{130}$ They announced a general strike and called upon ordinary citizens to serve on brigades de defense de la constitution. ${ }^{131}$ "Flaming barricades have risen throughout the country," Soukar

128. Constitution de la République d'Haïti (1987), Articles 61-87 and 263, in Deux siècles des constitutions haïtiennes: textes complets de 28 constitutions dont 12 amendements, vol. 2 (Port-au-Prince: Editions Fardin, 1998), 170-88. Also see Décentralisation et collectivités territoriales en Haïti: un état des lieux (Port-au-Prince: Editions Cahiers Universitaires, 2004), in which Claude Moïse and Fritz Deshommes analyze how the Assemblée Constituante tried to break up centralized power.

129. Constitution de la République d'Haïti (1987), Article 191.

130. Comité de Coordination des 57 , Declaration (8 July 1987), BDCO, box 46 : 5109040. Also see the statement by CATH in Libération (July 1987): 23.

131. Comité Ad-Hoc des Brigades de Defense de la Constitution, Declaration (1 July 1987), BDCO, box 46: 5109045. 
observed. ${ }^{132}$ "The anger of the people is growing." They burned US flags and plastered the phrase, "down with Reagan!" across government buildings. ${ }^{133}$

Although the business community had encouraged the CNG to implement a plan that polarized the country, it censured Namphy's "political naïveté." The "new electoral law" and "the strong-armed tactics of closing down the CATH labor union," in actuality, "made matters worse," HAMCHAM complained. ${ }^{134}$ "Each strike day means reduced national productivity." Banks suspended operations, and employees had to be bused to the industrial park because the strike paralyzed public transportation.

On 23 July 1987, the growing tension resulted in tragedy, as wealthy landowners and Tonton Macoutes led an assault on Tét Ansanm in Jean-Rabel. One victim described how the "attackers rolled boulders down on us." They shouted, "cut them down with your machetes!" ${ }^{135}$ Nearly 100 people were killed. When asked how many people died, however, one assailant proudly replied,

132. Soukar, 14.

133. " 4.000 étudiants manifestent contre le gouvernement à Port-au-Prince," Le Matin (23 July 1987): 1, 4.

134. "Political Turmoil Rocks Haiti" and "Impact of Recent Strikes on the Economy," HAMCHAM Newsletter (August 1987), BDCO, box 57: 13.

135. Dieulan Corgelas with Bernard Diederich (28 July 1987), BDCO, box 44: 5103004. Also see Diederich, Report (29 July 1987), same collection, box 43: 5101020 . 
"1,042 on the communist side, 10 on the American side." ${ }^{136}$ He portrayed the peasants as Soviet agents and implored the US to support the Macoutes.

The Reagan Administration condemned the attack but insisted that everyone trust the CNG. Reassured by Namphy's decision to reinstate the Conseil Electoral Provisoire, Ambassador Brunson McKinley maintained that "the CNG remains the framework most likely to deliver Haiti's warring social classes and political forces to elections." ${ }^{137}$ The business community agreed. Convinced that Bazin could still win the presidency, André Apaid demanded that Namphy arrest the Macoutes, who threatened to get in the way. Namphy promised him that "it would take [only] 15 deaths on election day to settle things." ${ }^{138}$ Apaid wrongly assumed that Namphy meant 15 Macoutes.

On election day, 29 November 1987, the military and the Macoutes converged on the Ecole Argentine de Bellegarde in Port-au-Prince, where Haitians had lined up to vote, and they gunned down over a dozen innocent people. Apaid had to console his foreman, whose wife was shot outside the Ecole Argentine. "When one of the killers lifted his machete to finish the job," Apaid sobbed," she pleaded with him to allow her to say goodbye to her husband

136. Anonymous Tonton Macoute, Statement (no date), BDCO, box 44: 5103004.

137. Memo (20 July 1987), AWHM, box 1: "Embassy." Also see Richard Holwill, Testimony (23 July 1987), BDCO, box 46: 5109032 .

138. Bernard Diederich, Report (7 December 1987), BDCO, box 43: 5101011. 
dying by her side," except "the man next to her was already dead and was not her husband!"139

The business community circulated a petition, demanding that Namphy submit to the constitution. "The private sector still anxiously and urgently insists on an electoral process," the petition stated, but it lacked a key endorsement. ${ }^{140}$ Disturbed by what transpired on election day, Apaid abandoned his assembly plants and his workers. He rushed to the airport, boarded a plane, and left the country.

Meanwhile, the US was bombarded with complaints, "denounc[ing its] involvement in the... botched election." ${ }^{141}$ A young Haitian theologian, JeanBertrand Aristide, eviscerated the Reagan Administration. "We have called the American government an accomplice!" he exclaimed. "Like a big overlord, [Reagan] said, 'okay, we have to have elections, so we'll help the CNG do it!"'142 Embarrassed by what happened on election day, George Shultz canceled 65 million US dollars in assistance. ${ }^{143}$

Forsaken by Reagan and Apaid, Delatour could only watch as his utopian vision slipped away. Unnerved by the Haiti's instability, multinational corporations

139. Ibid.

140. "Note de Presse du Sector Privé," BDCO, box 38: 5049008.

141. Petition (11 January 1988), BDCO, box 45: 5109003.

142. Jean-Bertrand Aristide, Statement (6 December 1987), HDCO, box 1 : "Interviews."

143. "Conclusion alarmante du Ministre Noel concernant suppression par Reagan de aide américaine," Le Matin (20 December 1987): 1. 
abandoned the assembly plants, and the country's total exports plummeted by 30 percent. ${ }^{144}$ Without US assistance, the Banque Nationale had to print 50 million Gourdes, which led to a new spike in commodity prices. ${ }^{145}$

Tragically, the Ministère des Finances had "no true desire to return to fiscal and monetary discipline." To the contrary, it reported that "the end of foreign aid due to the events of 29 November 1987 was an economic shock that undermined the [reform] program and marked its abandonment.."146 Delatour resigned in February 1988.

144. As calculated by André Lubin in "L'Importance d'une competitivité des exportations haïtiennes dans le contexte actuel de crise de devises," $B R H$ magazine (June 1991): 61-95, electronics exports declined in total value by 18 percent by 1987, and the textile industry, which increased in total value by 21 percent between 1986 and 1987, would grow by less than 9 percent in the next three years.

145. In the International Financial Statistics Yearbook, vol. 43 (1990), 442-43, the IMF documented a 11.5 percent decrease in commodity prices between 1986 and 1987 that quickly gave way to a 10.2 percent increase by 1989 . Also see Ministère des Finances, "Ajustement économique: le lien entre les politiques et le rétablissement des équilibres," in Haïti et l'après-Duvalier, eds. Cary Hector and Hérard Jadotte, vol. 1 (Port-au-Prince: Henri Deschamps, 1991), 269

146. Ministère des Finances, "Politique économique: la mise en œuvre d'une politique d'ajustement revue et élargie est préconisé," in Haïti et l'après-Duvalier, vol. 1, 280. 


\section{THE END OF UTOPIA}

Thou hast faith, and I have works: shew me thy faith without thy works, and I will shew thee my faith by my works.

\section{- James 2:18}

"Mistrust. Skepticism. Cynicism." The economist, Marc Bazin, shook his head. "It is necessary... to destroy... this wall of fatalism!" he exclaimed. ${ }^{1}$ Nearly three years had passed since the Election Day Massacre of 1987. Overthrown by his own lieutenant, Henri Namphy was now in exile, and a new presidential election was well underway. Bazin was back on the campaign trail, promoting his latest vision. "By the year 2000," he promised, "everyone—men, women, children, peasants, and city dwellers-will know how to read and write. They will have access to healthcare and will have enough to eat. They will have both the opportunity to work and an income so they can buy a respectable home." ${ }^{2}$ Haiti has "a new [national] destiny!"

Bazin imagined Haiti as a heavenly utopia, built upon technical knowledge, the "common good," and "human dignity." ${ }^{3}$ Like the ODVA

1. Marc Bazin, Miser sur l'homme: une vision globale pour une nouvelle société (Port-au-Prince: MIDH, 1990), 20.

2. Ibid., 14, 31.

3. Marc Bazin, "Pour une nouvelle morale politique," in Discours et messages, vol. 1, Le défi démocratique (Port-au-Prince: Henri Deschamps, 1989), 195. Also 
technician, Marc Holly, he wished to irrigate the Artibonite Valley. ${ }^{4}$ He also planned to promote Western medicine and contraception, like the physician, Ary Bordes. "Haiti," he lamented, "was among the most densely populated countries in the world." ${ }^{5}$

Bazin was not unique. As shown throughout my dissertation, many technicians were also utopians. The paradise they envisioned, however, was not always the "high mass-consumption" dreamworld promoted by policymakers. Guided by the utopian impulse, many specialists transcended high-modernist ideology, protested US hegemony, or opposed the Duvaliers. Contrary to how they have been portrayed in the historiography, they were not uncritical, unscrupulous zealots. To the contrary, they commonly embraced humanist principles, like liberty and equality, and they desired, above all else, a just society. While they did not always see eye to eye with the Haitian people, they nonetheless deserve a history that is "culturally sensitive, multivocal, and interactive."

Although they tried, Bazin's predecessors were unable to build the utopias they envisioned. They came up with complex plans to improve the country, but

see "Democratic Transition in Haiti," an essay by Bazin in The Yale Journal of International Law 13, no. 2 (Summer 1988): 303-12.

4. Marc Bazin, "Un plaidoyer et un plan de sauvetage pour la province haïtienne," in Discours et messages, vol. 2, Construire ensemble (Port-au-Prince: Henri Deschamps, 1990), 147-68.

5. Marc Bazin, "Population et développement," in Le défi démocratique, 152.

6. Joseph, "Close Encounters," 15. 
they were unable to appease both policymakers and the Haitian people. Bazin was nonetheless unyielding. Now that Jean-Claude Duvalier was gone, he argued, anything was possible. "The moment has come to aim higher and think bigger!" he declared. "What do we want this nation to look like and how are we going to make [that vision a reality]?"7

Blessed with technical knowledge, Bazin insisted that he was the best candidate to implement a new national vision. He praised the peasantry and its practices yet blanketed the countryside with his own curriculum vitae.

"Education," it stated, "Université de Paris, Solvay Institute, American University." ${ }^{8}$ From Port-au-Prince to the Artibonite Valley, he boasted about his experience as the World Bank's special envoy to the UN. He also spoke about his involvement with the World Health Organization in Benin, Burkina Faso, and the Ivory Coast.

By the time Bazin unveiled his 132-page plan, however, the Haitian people had given up on technocracy. So many specialists with grand visions had come and gone without solving the country's problems that most Haitians were ready to move on without them. The local theologian, Jean-Bertrand Aristide, said what everyone was thinking. "The jargon of the economist... infuriate[s] me!" he snapped. "[We must] proceed slowly, at our own pace, with insight from those who are in touch with the people" and avoid the "models provided by

7. Marc Bazin, "Message à la nation," in Construire ensemble, 97.

8. Marc Bazin, Curriculum Vitae (no date), BDCO, box 46: 5109034. 
specialists." ${ }^{9}$ According to Aristide, Haiti "does not [need] a wizard," like Bazin. To the contrary, "the political sphere and the economy" need only basic human principles: "dignity, simplicity, [and] participation.."10

The Kingdom of God

Since the technicians seemed incapable, many Haitians turned to Aristide, who envisioned a nation built solely upon human dignity. ${ }^{11}$ "Utopia?" he asked. "It is possible [if] we work together." ${ }^{12}$ On 18 October 1990, Aristide announced his candidacy for president and proposed a new democracy, a "lavalas" or flood, that would be "participatory, uncomplicated, and in perpetual motion." Unlike Bazin, who advocated both technocracy and democracy, Aristide insisted they were mutually exclusive and proclaimed his devotion to the Haitian people. Should "I have any talent as a visionary," he explained, "I owe it to [the people] who march at my side. My vision in politics [and] my faith in Christ are sustained by [my] community." ${ }^{13}$

9. Jean-Bertrand Aristide with Christophe Wargny, Tout homme est un homme (Paris: Editions du Seuil, 1992), 128.

10. Ibid., 149.

11. Sergio Ferrai examines Aristide's utopian impulse in Sembrando utopia: reportajes y conversaciones con Jean-Bertrand Aristide (Managua: Editiones Nicarao, 1992).

12. Aristide with Wargny, 121-26.

13. Ibid., 151. 
Aristide practiced liberation theology, which swept across Latin America and the Caribbean in the late twentieth century. The "theology of liberation" dates back to the Second Latin American Bishop's Conference in Medellín in 1968, when the Catholic hierarchy expressed solidarity with those in poverty. ${ }^{14} \mathrm{It}$ quickly spread through "base ecclesial communities," what Haitians call the "ti legliz," i.e. the "little church." ${ }^{\text {15 }}$ As explained by the Peruvian theologian, Gustavo Gutiérrez, base communities, such as Aristide's parish in Port-au-Prince, "protest [those who] trample human dignity" and participate "in the struggle against the plunder of the vast majority of human kind." ${ }^{\text {16 }}$ They try to "build... a new, just, and [brotherly] society," modeled not on the US or the USSR but on the "Kingdom of God."

Liberation theology seized upon the utopian impulse in Christianity. Historically, the impulse was inactive, says Ernst Bloch, because utopia was

14. Christopher Rowland, "The Theology of Liberation," in The Cambridge Companion to Liberation Theology (New York: Cambridge University Press, 2007), 3-4. Also see Michael Löwy, "The Historical Meaning of Christianity of Liberation in Latin America," in Coloniality at Large: Latin America and the Postcolonial Debate, eds. Mabel Moraña, Enrique Dussel, and Carlos A. Jáuregui (Durham: Duke University Press, 2008), 350-60.

15. Daniel H. Levine analyzes the "base ecclesial communities" in Popular Voices in Latin American Catholicism (Princeton: Princeton University Press, 1992), 45. Also see Laënnec Hurbon, Religions et lien social: l'église et l'état moderne en Haïti (Paris: Cerf, 2004); Louis Auguste Joint, Education populaire en Haïti: ti kominote legliz (Paris: L'Harmattan, 1996); Micial M. Nérestant, Religions et politique en Haïti, 1804-1990 (Paris: Karthala, 1994).

16. Gustavo Gutiérrez, A Theology of Liberation: History, Politics, and Salvation (originally published in 1971), trans. Caridad Inda and John Eagleson (Maryknoll: Orbis, 1988), 12. 
blasphemy. The Holy See insisted that the Kingdom of God was "not of this world." Nevertheless, utopian imagery was ubiquitous in both the Old Testament and the New. ${ }^{17}$ Jürgen Moltmann, whose Theology of Hope (1965) inspired many liberation theologians, explicates how "the hope of the Gospel has a polemic and liberating relation not only to the religions and ideologies of men, but still more to the factual, practical life of men and to the relationships in which this life is lived." Those who truly believe in the Gospel, he argues, cannot stay neutral toward "industrial society." To the contrary, "social and public life" must "transform... the face of the world." ${ }^{18}$

Liberation theology was overtly political. "Why not talk about politics?" Aristide asked rhetorically. ${ }^{19} \mathrm{He}$ blamed poverty and oppression on Christianity's political neutrality. In his book, Névrose vétéro-testamentaire (1994), he explained how neutrality caused a psychological neurosis, much like bovarism. ${ }^{20}$

17. Ernst Bloch, Atheism in Christianity: The Religion of the Exodus and the Kingdom (originally published in 1968), trans. J.T. Swann (New York: Herder \& Herder, 1972), 26.

18. Jürgen Moltmann, Theology of Hope (originally published in 1965), trans. Margaret Kohl (San Francisco: Harper \& Row, 1991), 305, 330. Also see "Critique and Justification of Utopia," Utopias and Utopian Thought, ed. Frank E. Manuel (Cambridge: Riverside Press, 1966), 308, in which Paul Tillich states that "a Kingdom of God that is not involved in historical events, in utopian actualization in time, is not the Kingdom of God at all."

19. Jean-Bertrand Aristide, Théologie et politique (Montréal: CIDIHCA, 1992), 15.

20. Jean-Bertrand Aristide, Névrose vétéro-testamentaire (Montréal: CIDIHCA, 1994), 9. 
Christians, "to this very day, experience les troubles névrotiques," Aristide claimed, "because they disavowed [God's] true message."11

Aristide had a lot in common with Karl Marx. Although Marx condemned religion as "the opium of the masses," his vision for a classless society "[was] unquestionably rooted in the original Christian ground plan for the Kingdom of Freedom," as explained by Ernst Bloch. ${ }^{22}$ Likewise, the utopian impulse behind liberation theology anticipated a communist-style revolution. ${ }^{23}$ "You cannot avoid class struggle in Port-au-Prince," Aristide attested. ${ }^{24}$ "Communism," however, was a "condemnatory epithet," so he would instead quote the utopian socialist,

21. Aristide, Théologie et politique, 24.

22. Bloch, Atheism in Christianity, 268-69. In his essay, "Marxism and Religion," in Marxism and Christianity (New York: Humanities Press, 1968), 31-32, Herbert Aptheker explains how "Marxism emphasizes the revolutionary quality of early Christianity" and "the religiosity of the masses," who "see in their religious beliefs goads" for "battle on earth." Also see On Marxism and Christianity (originally published in 1968), trans. Kevin Traynor (New York: Macmillan, 1968), 263, by Giulio Girardi, who notes how "the differences between the two [philosophies], radical as they are, do not exclude the possibility of broad and deep convergence at the level of ideals," most notably "humanism." This "convergence," he states, "could lay the foundation for a program of common action."

23. In his book, A Theology of Liberation, 135-37, Gustavo Gutiérrez insists that "utopia necessarily means a denunciation of the existing order." Also see Enrique Dussel, "Liberation Theology and Marxism," Rethinking Marxism 5, no. 3 (Fall 1992): 50-74; Vincent Geoghegan, Utopianism and Marxism (New York: Methuen, 1987), 93-94; Denys Turner, "Marxism, Liberation Theology and the Way of Negation," in The Cambridge Companion to Liberation Theology, 229-47.

24. Aristide with Wargny, 58, 106. 
Richard Lahautière, whose Petit catéchisme (1839) visualized a world without inequality. "[l] would like the same utopia [as Lahautière]," he proclaimed. ${ }^{25}$

Presented with two bold visionaries, the technician, Bazin, and the theologian, Aristide, the Haitian people, on 16 December 1990, chose the latter. Bazin won only 233,277 votes, while Aristide received $1,107,125 .{ }^{26}$ Bazin shook his head. "The people made Aristide president," he explained, "because they [are] frustrated" with technocracy and "the system." ${ }^{27}$ Aristide had no experience in government, Bazin complained. "[His] ability to govern the country," however, "was beside the point." Haiti's unresolved "social struggle" had provoked "passion" and "resentment." Gone were "reason" and "common sense."28

Few Haitians shared Bazin's opinion. On 7 February 1991, a massive crowd assembled beside the Palais National in Port-au-Prince to celebrate Aristide's inauguration. "From now on," Aristide promised, "lavalas," the people, "will rejuvenate the nation!"29 He avoided "mystifying terms," like "[economic] growth," and instead spoke about equality. "Should the poor share in the

25. Ibid., 145-46.

26. "Président Aristide," Le Nouvelliste (24 December 1990): 1.

27. Marc Bazin, Haïti 92: démocratie sous pression (Port-au-Prince: Henri Deschamps, 1995), 256-57.

28. Ibid.

29. Jean-Bertrand Aristide, Address (7 February 1991), BDCO, box 62: 6109028. 
country's wealth?" he asked. "Yes!" the people replied. Aristide smiled. Finally, "the stones in the water will learn the pain of those in the sun!"

\section{A Faustian Bargain}

Spurned by the Haitian people, technicians would nonetheless impose themselves on the nation. The opportunity came on 31 October 1991, when conservatives in the Haitian military led by Lieutenant-General Raoul Cédras pushed Aristide into exile and invited Marc Bazin to lead a new civilian government. Bazin believed it was his duty to solve the crisis. "The battle between Aristide and Cédras" turned "the [Haitian] people against the military" and "the poor against the rich," he explained. ${ }^{30}$ It "threatened to break Haitian society [in two]." Forced to make a choice between technocracy and democracy, Bazin abandoned the humanist principles he once vowed to uphold. In doing so, he threw away what little credibility technicians had in the eyes of the Haitian people.

Bazin was appointed Premier Ministre. His installment, however, was a joyless event compared to Aristide's inauguration. At 9:45 am on 19 June 1992, Bazin was met by the Service du Protocole and a military escort, which took him to the Palais National. "On the road to Port-au-Prince," Bazin recalled, "there

30. Bazin, Haïti 92, 17-19. 
were few crowds and no applause."31 Fortunately, "there was no hostility, either." He looked out the window and tried to guess what people were thinking. "[They] had the look of acceptance." The investiture began at 10:10 am. "The ceremony [included] hymns, speeches, a military inspection, and celebratory canon fire," but it ended early. At 2:00 pm, Bazin went home. "I [wanted to] think about my new responsibility."

Bazin lacked a democratic mandate but implemented his ideas anyway. On 25 August, he summoned the country's top specialists: the industrialist, Jacques Baker, the economist, Wiener Fort, the engineer, Jean Carmelo Pierre Louis, and the agronomist, Jean André Victor. "We must... create an inventory of development projects," he told them. It should include "urban and rural development... primary and secondary education [and] healthcare for women and children." ${ }^{32}$ It was necessary "to present these initiatives [to the US] as 'humanitarian,"' he explained, because the international community had imposed an embargo on Haiti to punish the military. Bazin also worked with André Apaid and the C-CAA to help multinational corporations navigate the crisis. ${ }^{33}$

Many Haitians condemned the new technocracy. "President Aristide says the military appointed [me] to buy time," Bazin grumbled. "[His] lavalas [thinks]

31. Ibid., 24-25.

32. Marc Bazin to Wiener Fort et al. (25 August 1992), BDCO, box 62: 6109014.

33. Peter B. Johnson to Marc Bazin and André Apaid (25 June 1992), BDCO, box 50: 6049007 . 
my intervention will merely legitimize the [military] coup," but "this accusation is unjust." ${ }^{34}$ Antipathy toward Bazin increased exponentially in 1993, when Cédras condoned a new paramilitary organization, the Front pour l'Avancement et le Progrès Haïtien (FRAPH), that killed an estimated 4,000 people. ${ }^{35} 50,000$ to 150,000 people tried to escape the country in tiny boats. "Everyone criticizes me!" Bazin bewailed. ${ }^{36}$ "Some [think] I am being held hostage by the military!" Others "[say] I am misguided" and "a martyr for a lost cause."

Bazin would have stayed the course had the US not pressured Cédras to back down. According to Bazin, President Bill Clinton believed "Aristide's return would bring back democracy" and "stop the [so-called] 'boat people,"' who "haunted [America's] conscience."38 Finally, on 8 June 1993, Cédras asked Bazin

34. Bazin, Haïti 92, 16, 25.

35. As stated by Jeb Sprague in Paramilitarism and the Assault on Democracy in Haiti (New York: Monthly Review Press, 2012), 16-17, "FRAPH was founded in part at the behest of the US Defense Intelligence Agency" in 1993. It "worked closely with Haiti's military and was used across the country to carry out brutal killings and attacks" on Aristide's "popular movement."

36. Bazin, Haïti 92, 15-16.

37. History has not been kind to Bazin. In his book, Haïti: misère de la démocratie (Paris: L'Harmattan, 1999), 186-91, Sauveur Pierre Etienne says "the Prime Minister was treated like a petit caporal by the military. [He] promised to create 100,000 jobs... restore diplomacy... and address the economic sanctions, but this was only a dream." In reality, his presence merely "exacerbated [the] repression, corruption, and nepotism" perpetrated by the military. Also see Damming the Flood: Haiti and the Politics of Containment (London: Verso, 2007), 39-73, in which Peter Hallward implicates Bazin in an international conspiracy to suppress liberation theology.

38. Bazin, Haïti 92, 189. 
to resign so the military could negotiate with Aristide. ${ }^{39}$ "Everyone knows what happened next," Bazin groaned. Diplomacy sputtered, and "it took the invasion of 20,000 [US] Marines [to push] Cédras [into] exile. [Cédras] lost. Aristide returned. He won." 40

Aristide reclaimed the presidency on 15 October 1994. The second coming, however, was less a victory than a compromise. The US government insisted that he work with Leslie Delatour, a former associate of Bazin, to privatize the country's state-owned enterprises. ${ }^{41}$ It also demanded that he approve an "Emergency Economic Recovery Program." Rolled out by the InterAmerican Development Bank in 1994, the Recovery Program lowered taxes on international commerce to stimulate private investment. It also limited government expenditures, which inhibited Aristide's ability to redistribute wealth. ${ }^{42}$

39. Raoul Cédras to Marc Bazin (8 June 1993), BDCO, box 62: 6109037.

40. Bazin, Haïti 92, 254. Also see Philippe Girard, Clinton in Haiti: The 1994 US Invasion of Haiti (New York: Palgrave Macmillan, 2004); Ralph Pezzullo, Plunging into Haiti: Clinton, Aristide, and the Defeat of Diplomacy (Jackson: University of Mississippi Press, 2006).

41. In his book, Haïti: ajustement structurel et problèmes politiques (Paris: L'Harmattan, 1998), 46-7, Fritzner Gaspard explains how Delatour presented his "stratégie de reconstruction sociale et économique" at peace negotiations in Paris and insisted that "democracy in Haiti [was] incompatible with the existence of public enterprises." Pierre Mouterde and Christophe Wargny, meanwhile, expose how the Clinton Administration used the Marine invasion as leverage over Aristide in Apre bal tanbou lou: cinq ans de duplicité américaine en Haïti, 1991-1996 (Paris: Editions Austral, 1996), 191-94.

42. As stated by Yasmine Shamsie in "The Economic Dimension of Peacebuilding," Haiti: Hope for a Fragile State (Waterloo: Wilfrid Laurier 
In 2001, the US pushed Aristide to appoint Marc Bazin as Ministre du Plan et de la Coopération Externe. ${ }^{43}$ The two men had mutually exclusive perspectives on technocracy yet came to an agreement. "We produced a carte de la pauvreté" and "[improved] how the economy was managed," Bazin explained. ${ }^{44}$ "[We even] challenged the World Bank to [think about] the needs [of the Haitian people]." In 2002, Aristide promoted Bazin to Ministre de la Négociation. Bazin laughed. "As always, [l] served... nobly and objectively."

\section{The Postmodern Condition}

Most Haitians perceived the compromise between Aristide and Bazin as blatant hypocrisy. By the time Aristide's presidency ended in 2004, they mistrusted liberation theology, technocracy, and utopianism in general. Haiti also lost hope in the US (Fig. 24). As noted by Gérard Pierre-Charles in Haití: pese a todo la utopía (1999), the country became locked in a "systemic crisis of authority

University Press, 2006), 43, "the [Emergency Economic Recovery Program] was followed in 1996 by a long-term 1.2 billion US dollar development and reconstruction plan;" then, "in 2004, donors," led by the World Bank, "advanced a new short-term plan, the Interim Cooperation Framework" that "place[d] a strong emphasis on the reactivation of export-manufacturing."

43. Alex Dupuy analyzes the "low-intensity war" on Aristide in The Prophet and Power: Jean-Bertrand Aristide, the International Community, and Haiti (Lanham: Rowman \& Littlefield, 2007), 135-70.

44. Bazin with Duval and Pierre, 75. 


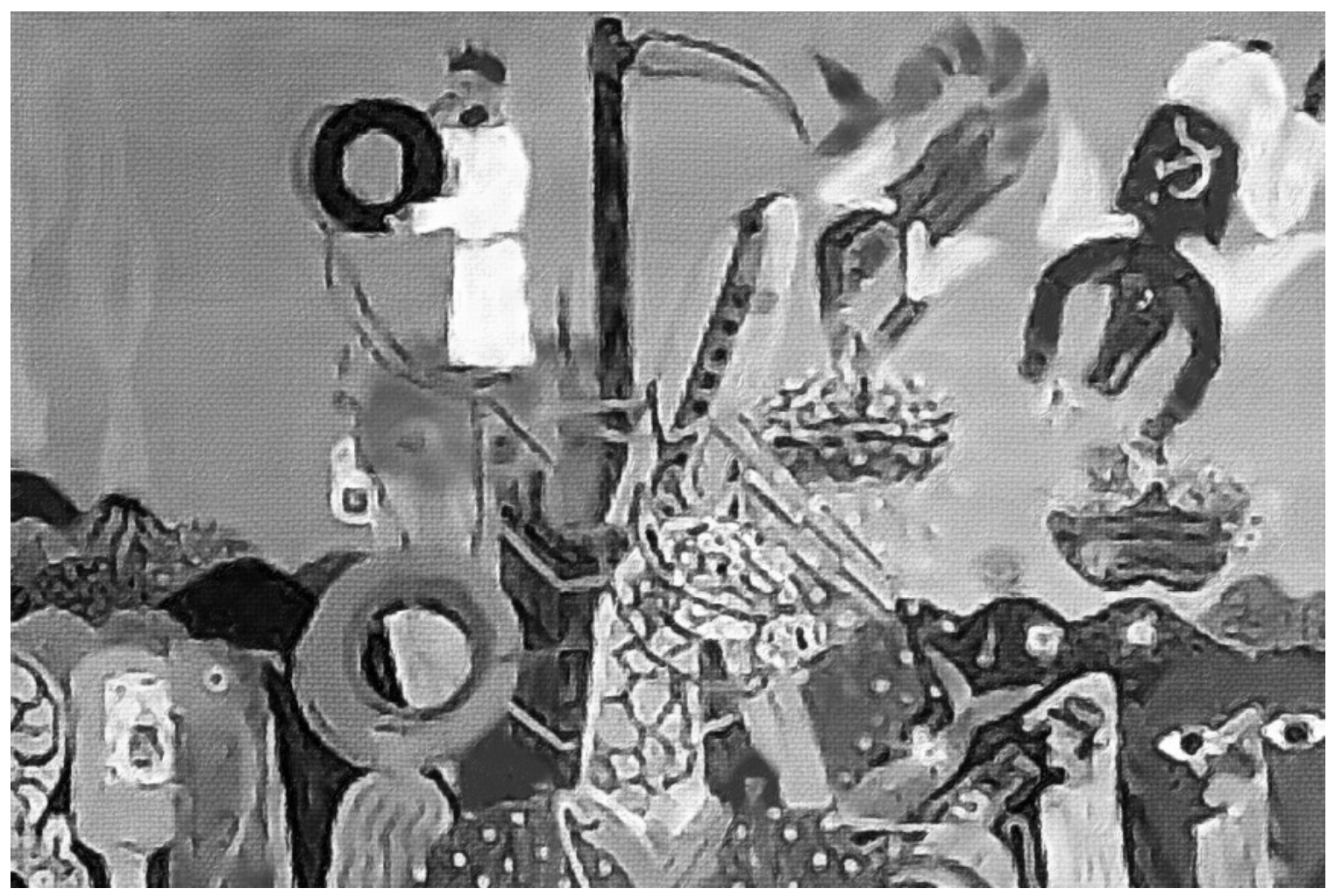

Fig. 24 "Bourik Chaje" by Franz Zephirin. Zephirin portrays US Ambassador Alvin Adams as an overloaded donkey, who abandoned Haiti with modernity in tow, while the US and its rivals (marked by the Soviet insignia) continued to lavish the country with flowery promises like heavenly angels. From: Bill Bollendorf, Private Collection. Reproduced with permission.

and legitimacy. ${ }^{45}$ Fatalism wrought a desolate postmodernity in which ambitious plans like the Organisation de Développement de la Vallée de l'Artibonite and the Plan de développement de Port-au-Prince et de sa region métropolitaine became increasingly unthinkable. ${ }^{46}$

45. Gérard Pierre-Charles, Haití: pese a todo la utopía (Ciudad Universitaria: Universidad Nacional Autónoma de México, 1999), 111-14.

46. In the book, Le défi haïtien: économie, dynamique sociopolitique et migration (Paris: L'Harmattan, 2011), 15, Carlo A. Célius bewails how Haiti is overwhelmed by "economic [crises], population growth, violence, social exploitation, endemic poverty, AIDS, religious tension, corruption, illegal 
Cynicism in Haiti paralleled that in the international community in the late twentieth century. When the Soviet Union dissolved in 1991, many people gave up on alternatives to the modern world-system. ${ }^{47}$ "We are now in a remarkable situation," says Francis Fukuyama. "Critics of liberal societies" and the capitalist world-economy "are singularly lacking in radical solutions to overcoming the more intractable forms of inequality. ${ }^{38}$

As a result, the collective journey to utopia gave way to an "individualized, privatized" modernity, where everyone worked within the world-economy to

trafficking, shantytowns, environmental degradation," etc., "then take into account... the earthquake on 12 January 2010, the cholera epidemic, and political unrest." Philippe Girard is equally pessimistic in Paradise Lost: Haiti's Tumultuous Journey from Pearl of the Caribbean to Third World Hotspot (New York: Palgrave Macmillan, 2005). Also see Alex Dupuy, Haiti: From Revolutionary Slaves to Powerless Citizens (New York: Routledge, 2015); Robert Fatton, Jr., Haiti: Trapped in the Outer Periphery (Boulder: Lynne Rienner, 2013).

47. As observed by Richard Crossman in The God that Failed (New York Columbia University Press, 2001, originally published in 1950), this skepticism began very early and increased exponentially "as the intellectual [learned] more about the conditions" behind the Iron Curtain, the "brutality" and "loathsome tyranny." Examples include Daniel Bell, The End of Ideology: On the Political Exhaustion of Political Ideas in the Fifties (New York: The Free Press, 1960); Judith N. Shklar, After Utopia: The Decline of Political Faith (Princeton: Princeton University Press, 1957). Also see Jorge G. Castaneda, Utopia Unarmed: The Latin American Left After the Cold War (New York: Vintage, 1994); Eric Hobsbawm, "Goodbye to All That," in After the Fall: The Failure of Communism and the Future of Socialism, ed. Robin Blackburn (London: Verso, 1991); Alexei Yurchak, Everything Was Forever, Until it Was No More: The Last Soviet Generation (Princeton: Princeton University Press, 2005).

48. Francis Fukuyama, The End of History and the Last Man (New York: The Free Press, 1992), 293. 
obtain what they personally desired. ${ }^{49}$ As shown by Daniel T. Rodgers in The Age of Fracture (2012), "single, dominant ideas" broke into "intellectually compartmentalized... piecemeal, context-driven" perspectives on what the world should look like. ${ }^{50}$ Even humanist principles, "once so tightly tied to [the nation and its] destiny, [became] disembodied, unmoored, [and re]imagined."

Grand visions had no place in this modernity. To the contrary, the word, "utopian," became synonymous with "impossible," and many people thought situationally transcendent ideas were dangerously naïve. ${ }^{51}$ "Little seem[ed] more quixotic... than defending the utopian impulse," laments Russell Jacoby. ${ }^{52}$ "Utopianism seem[ed...] impractical and pointless," since "this society [looked

49. In his book, Liquid Modernity (New York: Polity Press, 2000), 7-8, Zygmunt Bauman examines how personal "life-politics" became "unstructured" and "fluid," while "systemic structure[s]" became "remote" and "unreachable." Also see "Utopia with No Topos," an essay by Bauman in History of the Human Sciences 16, no. 1 (2003): 11-25; Martín Hopenhayn, "Postmodernism and Neoliberalism in Latin America," in The Postmodernism Debate in Latin America, eds. John Beverly, José Oviedo, and Michael Aronna (Durham: Duke University Press, 1995), 93-109.

50. Daniel T. Rodgers, The Age of Fracture (Cambridge: Belknap Press, 2012), 10-11, 17.

51. As illustrated by Frederic Jameson in Postmodernism, Or, the Cultural Logic of Late Capitalism (Durham: Duke University Press, 1991), 335, "antiutopian" thought, "now conventional," maintains that a revolutionary idea "is in reality dangerous and leads... to Stalin's camps, to Pol Pot, and to... massacres." The book, Utopia and Revolution (Chicago: University of Chicago Press, 1976) by Melvin J. Lasky, condemns utopianism as "apocalyptic ecstasy."

52. Russell Jacoby, The End of Utopia: Politics and Culture in an Age of Apathy (New York: Basic Books, 1999), 179-80. 
like] the only possible one." Sadly, "imagination and hope... withered," and "no one even pretend[ed] to believe in a different future."

In his book, No Apocalypse, No Integration: Modernism and

Postmodernism in Latin America (2001), Martín Hopenhayn explains how "the political and cultural defeat of the left, plus the political and technical defeat of development policy and its national variants, dismantled the Latin American social sciences' greatest source of legitimacy, which was [their] claim to... knowledge... and the radical transformation of social structures. ${ }^{" 53}$

It was in this context that technocracy shattered into tiny, nongovernmental organizations (NGOs). By 2010, Haiti was home to nearly 10,000 NGOs, each with its own petite vision. Sponsored by USAID to circumvent Aristide's presidency, NGOs employed both Haitian and non-Haitian technicians, who provided everyday services to individual communities. ${ }^{54}$ As observed by one witness, "NGOs in Haiti created a 'brain drain' in public sector employment."

53. Martín Hopenhayn, No Apocalypse, No Integration: Modernism and Postmodernism in Latin America, trans. Cynthia Margarita Tompkins and Elizabeth Rosa Horan (Durham: Duke University Press, 2001), xvii.

54. Sauveur Pierre Etienne, Haïti: l'invasion des ONG (Montréal: CIDIHCA, 1997), 18. Also see Pierre Salignon, "Haïti, république des ONG: l'empire humanitaire en question," in Haïti aujourd'hui, Haïti demain: regards croisés, eds. Andrea Martinez, Peirre Beaudet, and Stephen Baranyi (Ottawa: Presses de I'Université d'Ottawa, 2011), 185-97; Beguens Théus, ONG et pauvreté en Haïti (Port-au-Prince: Editions Mémoire, 2011). 
They "eroded the legitimacy of the government" and its capacity to implement a plan national. ${ }^{55}$

Sadly, it took the worst tragedy in Haitian history to awaken the utopian impulse. On 12 January 2010, a 7.0 M earthquake leveled Port-au-Prince and the nearby settlements, killing an estimated 100,000 to 230,000 people ${ }^{56}$ In response, President René Préval introduced a 10-year plan to rebuild the nation. ${ }^{57}$ Much like the Plan de développement de Port-au-Prince, the new Plan d'action pour la reconstruction et développement national stipulated that technicians should "evenly distribute the population throughout the country." 58 Haiti must "improve the [areas] that will become centres de développement," it stated, "so they can provide economic opportunity, employment, and [an improved] standard of living to inhabitants."

55. Terry F. Buss with Adam Gardner, Haiti in the Balance: Why Foreign Aid Has Failed and What We Can Do About It (Washington, D.C.: Brookings Institution, 2008), 118-19.

56. In the essay, "Maudite press," in Haïti, réinventer l'avenir, eds. Suzy Castor, Fritz Deshommes, and Laënnec Hurbon (Port-au-Prince: Editions de l'Université d'Etat d'Haïti, 2012), 115, Arnaud Robert explains that no one knows exactly how many people were killed by the earthquake. "The [original] statistic, 100,000, was announced by the Ministère de l'Intérieur [on 13 January 2010], but it has since been increased... to $230,000 . "$

57. "Les grands chantiers de la reconstruction," Le Nouvelliste (4 June 2010): 1.

58. Government of Haiti, Chef de l'Etat, Plan d'action pour la reconstruction et développement national: les grands chantiers pour l'avenir (Port-au-Prince: Imp. de l'Etat, 2010), 17. 
The Haitian government and the UN instituted a new Commission Intérimaire, led by Bill Clinton and Premier Ministre Max Bellerive, to implement the Plan d'action. "For Haiti," Clinton averred, "the moment has come" to "build a better future," a "nation that finally reflects" everyone's "desires" and "dreams." Understandably, many Haitians were skeptical, as the Commission did not even try to address the political and economic structures that keep Haiti in poverty. It merely distributed money to NGOs and private contractors. ${ }^{60}$

Marc Bazin was nonetheless buoyant. Until his death on 16 June 2010, he backed the Plan d'action. "I have a vision!" he exclaimed. "It inspires me and

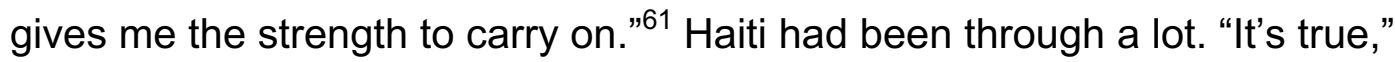
Bazin conceded. "We have fallen very hard." Nevertheless, "we must [pick ourselves] back up." Between Haiti and the heavens, he proclaimed, "there are always new paths to explore!"62

59. Bill Clinton, "Our Commitment to Haiti," Innovations 5, no. 4 (Fall 2010): 5.

60. As noted by Suzy Castor in "Refonder la nation haïtien," in Haïti aujourd'hui, Haïti demain: regards choisés, eds. Andrea Martinez, Pierre Beaudet, and Stephen Baranyi (Ottawa: Presses de l'Univeristé d'Ottawa, 2011), 109, the Commission "pioneered new voies de tutelle." Also see Haiti: After the Earthquake (New York: Public Affairs, 2012), 97, in which Paul Farmer concludes that "it wasn't a good idea to funnel foreign assistance exclusively through NGOs and private contracts," because "without real and sustained commitments to strengthening the public sector" and "its capacity to monitor and coordinate services offered by NGOs," there was no one to "make sure development funds were being used efficiently."

61. Bazin with Duval and Pierre, 54.

62. Fatally ill, Bazin was nonetheless determined to produce a multivolume plan to help the Haitian people. He published volume one, Des idées pour l'action (Port-au-Prince: Imp. II), in 2008 but was unable to complete the series. 


\section{BIBLIOGRAPHY}

Archival Research

AMSF

AWHM

BDCO

DCCO

DCOA

DDFS

DRCR

ECGR

FCHR
Agency for International Development, Mission to Haiti, Subject Files, 1957-1963. Records of the Agency for International Development, 1948-2003, Record Group 286, Entry No. P-357, National Archives at College Park, Maryland (NACP).

Amy Wilentz Haiti Material. New York Public Library, Schomburg Center for Research in Black Culture, Manuscripts, Archives, and Rare Books Division, New York, New York.

The Bernard Diederich Collection. Steven and Dorothea Green Library, Florida International University, Miami, Florida.

Duvalier Correspondence Collection. New York Public Library, Schomburg Center for Research in Black Culture, Manuscripts, Archives, and Rare Books Division, New York, New York.

Development Communications Archive. Dolph Briscoe Center for American History, University of Texas, Austin, Texas.

Donald Danner Files, 1985-1988. Ronald Reagan Library, Simi Valley, California.

Development \& Resources Corporation Records. Mudd Manuscript Library, Princeton University, Princeton, New Jersey.

United States Embassy in Port-au-Prince, Classified General Records, 1920-1964. Records of the Foreign Service Posts of the Department of State, 1788-1991, Record Group 84, Entry No. UD2669, NACP.

Foundation for Cooperative Housing Records. Global Communities, Silver Spring, Maryland. 
GSFR

HBCR

HDCO

IAAR

IEPR

JMFP

LALP

OMCF

OMUF

RJAP
General Service Foundation Records. Minnesota Historical Society, Saint Paul, Minnesota.

Boston Women's Health Book Collective Records. Arthur and Elizabeth Schlesinger Library on the History of Women in America, Radcliffe Institute, Harvard University, Cambridge, Massachusetts.

Haiti Dechoukaj Collection. New York Public Library, Schomburg Center for Research in Black Culture, Manuscripts, Archives, and Rare Books Division, New York, New York.

Bureau of Inter-American Affairs, Office of the Director for Caribbean Countries, Records Relating to Haiti, 1960-1974. General Records of the Department of State, 1763-2002, Record Group 59, Entry No. A1-3152, NACP.

Office of the Commissioner to the International Exposition for Founding of Port-au-Prince, Program Records, 1959-1951. Records of International Conferences, Commissions, and Expositions, 1825-1970, Record Group 43, Entry No. p170, NACP.

James Marston Fitch Papers. Avery Architectural and Fine Arts Library, Drawings and Archives, Columbia University, New York, New York.

Leonard A. Lovell Papers. American Heritage Center, University of Wyoming, Laramie, Wyoming.

United States Operations Mission to Haiti, Classified Subject Files, 1952-1962. Records of the Foreign Assistance Agencies, 1948-1961, Record Group 469, Entry No. 260, NACP.

United States Operations Mission to Haiti, Unclassified Central Subject Files, 1952-1962. Records of the United States Foreign Assistance Agencies, 1942-1963, Record Group 469, Entry No. 262, NACP.

Robert Jackson Alexander Papers. Archibald Stevens Alexander Library, Rutgers University, New Brunswick, New Jersey. 
UNAR

USCR

United Nations, Archives and Records Management Section, New York, New York.

Unitarian Universalist Service Committee Records. AndoverHarvard Theological Library, Harvard University, Cambridge, Massachusetts.

Government Documents

Government of Haiti. Bureau de Recensement. Recensement général de la République d'Haïti: population, habitation, agriculture en 1950. Port-auPrince: Imp. de l'Etat, 1950.

- Chef de l'Etat. Plan d'action pour la reconstruction et développement national: les grands chantiers pour l'avenir. Port-au-Prince. Imp. de l'Etat, 2010.

_. Commission d'enquête sur les dépossessions des paysans de la Vallée de l'Artibonite. "Rapport de la commission d'enquête." Port-au-Prince: Imp. de l'Etat, 1958.

- Conseil National de Développement et de Planification. Avancement des Travaux. Port-au-Prince: Imp. de l'Etat, 1969.

_ Conseil National de Développement et de Planification. "Plan de développement de Port-au-Prince et de sa region métropolitaine, projet d'action immédiates: renovation du centre de la capital." Port-au-Prince: Imp. de l'Etat, no date.

- Conseil National de Développement et de Planification. Plan quinquennal, 1976-1981. Port-au-Prince: Imp. de l'Etat, 1976.

_. Conseil National de Développement et de Planification and the United Nations Development Programme. "Avant projet pour la rehabilitation du quartier St. Martin.” Port-au-Prince: Imp. de l'Etat, 1977.

_ Conseil National de Gouvernement. Discours et messages: 7 février 1987 à 7 février 1987. Port-au-Prince: Henri Deschamps, 1987.

- Conseil National de Gouvernement. Lois et actes du Conseil National de Gouvernement du 7 février 1986 au 7 février 1988. 3 vols. Port-au-Prince: Imp. de l'Etat, 1988. 
—. Département de la Coordinationet de l'Information. 90 jours de gouvernement: de la prestation de serment à l'apotheose de Péligre. Portau-Prince: Presses Nationales d'Haïti, 1971.

—. Départment de la Justice. Le bulletin des lois et actes: 1er Janvier à 31 décembre 1949. Port-au-Prince: Imp. de l'Etat, 1949.

_. Institut Haïtien de Statistique, "Résultats préliminaires du recensement général la population, du logement et de l'agriculture." Port-au-Prince: IHS, 1973.

Institut Haïtien de Statistique. Bulletin trimestriel de statistique. Port-auPrince: IHS, 1974.

_. Institut Haïtien de Statistique. "Les logements et les manages." Port-auPrince: IHS, 1981.

- Ministère de l'Economie et des Finances. Bulletin trimestriel de conjoncture, no. 2. Port-au-Prince: Imp. de l'Etat, 1987.

—. Office d'Administration des Cités Ouvrières. La voix des cités ouvrières d'Haïti. Port-au-Prince: Imp. de l'Etat, 1955.

- Office National du Logement. Eléments pour une politique rationnelle de logement en Haïti. Port-au-Prince: Presses Nationales d'Haïti, 1979.

—. Office National du Logement. Projet de développement urbain. Etude de factibilité: sites et services. Port-au-Prince: Presses Nationales d'Haïti, 1980.

_- Office National du Logement. Rénovation urbaine et construction de logements sociax. Port-au-Prince: Presses Nationales d'Haïti, 1980.

_. Service Technique de l'Agriculture et de l'Enseignement Professionnel. "Rapport sur le relevé du sol de la plaine de l'Artibonite." Bulletin du Service Technique, no. 5. Port-au-Prince: Service Technique, 1926.

_. Service Technique de l'Agriculture et de l'Enseignement Professionnel. Eléments d'art paysager. Port-au-Prince: Service Technique, 1931.

Government of the United States. Agency for International Development. "Implementation of the Humphrey Amendment." Washington, D.C.: Government Printing Office, 1962.

Agency for International Development. "Shelter Sector Assessment: Haiti." Washington, D.C.: USAID, 1980. 
—. Agency for International Development. "Haiti: Country Development Strategy Statement.” Washington, D.C.: USAID, 1983.

- Agency for International Development and the Foundation for Cooperative Housing. Cooperative Housing and the Minimum Shelter Approach in Latin America, 2 vols. Washington, D.C.: USAID, 1972.

—. Department of Labor, Assistant Secretary Daniel Patrick Moynihan. "The Negro Family: The Case for National Action." Washington, D.C.: Office of Policy Planning and Research, 1965.

- Department of State. The Department of State Bulletin. Washington, D.C.: Office of Public Communication,1961.

_ Department of State, Bureau of Public Affairs. Current Policy. Washington, D.C.: Office of Public Communication, 1983.

- Department of State. Foreign Relations of the United States, vol. 12. Washington, D.C.: Government Printing Office, 2001.

_. Export-Import Bank. "Plan and Program for the Development of the Artibonite Valley." Washington, D.C.: Export-Import Bank, 1952.

- Institute of Inter-American Affairs. "The IIAA at Work." Washington, D.C.: Government Printing Office, 1954.

_. Institute of Inter-American Affairs, Food Supply Division. "A Summary Report: 1942-1947.” Washington, D.C.: Government Printing Office, 1947.

—. United States Information Service. Communiqué de presse. Washington, D.C. USIS, 1986.

_. United States Senate, Committee on Foreign Relations. After the Earthquake: Empowering Haiti to Rebuild Better. Hearing on 19 May 2010. 111th Congress.

International Monetary Fund. International Financial Statistics Yearbook. Washington, D.C.: IMF, 1980.

Tennessee Valley Authority. "The Norris Project: A Comprehensive Report." Washington, D.C.: TVA, 1940.

World Bank. "Haiti: Country Program Paper. Washington, D.C.: World Bank Group, 1983. 


\section{Unpublished Reports}

Augur, Tracy B. "The Planning of the Town of Norris." Presented to the Tennessee Valley Authority, Knoxville, Tennessee, 1936.

Delatour, Leslie. "The Essential Oil Export Sector of Haiti: Trends, Problems, and Policy Options." Presented to USAID, Washington, D.C., 1983.

Delatour, Leslie and Paul Duret. "Rice in Haiti." Presented to USAID, Washington, D.C., 1984.

Estimé, Jean-Robert. "International Sub-Contracting: The Case of Haiti."

Presented to the Organization for Economic Cooperation and Development, Paris, France, 1978.

Louis Berger International, Inc. Projets et planification en Haïti, vol. 4, Logement. Presented to the Conseil National de Développement et de Planification, Port-au-Prince, Haiti, 1977.

Mason, John P. "Miracle on Ave. St. Martin: A Lesson in Self-Help Housing from Port-au-Prince." Presented to the Foundation for Cooperative Housing, Washington, D.C., 1981.

Ronceray, Hubert de. "Le processus d'urbanisation à Port-au-Prince." Presented to the Ford Foundation in New York, New York, 1974.

Saint Surin, Jacques. "Indices démographiques et perspectives de la population d'Haïti de 1950 à 1980." Presented to the Haitian government, 1962.

St. Fleur, François. "Rapports sur les finances de Jean-Claude Duvalier et Cie." Presented to the Institute of Haitian Studies, University of Kansas, Lawrence, Kansas, 2000.

\section{Published Papers}

Duvalier, Jean-Claude. Discours et messages, vol. 1. Port-au-Prince: Henri Deschamps, 1978.

—. Discours et messages, vol. 2. Port-au-Prince: Henri Deschamps, 1979. 
Johnson, Lyndon B. The Public Papers of the President of the United States, 10 vols. Washington, D.C.: Government Printing Office, 1966-1970.

Lilienthal, David E. The Journals of David E. Lilienthal, 5 vols. New York: Harper \& Row, 1971.

Reagan, Ronald. The Public Papers of the Presidents of the United States, 15 vols. Washington, D.C.: Government Printing Office, 1983-1991.

Roosevelt, Franklin D. The Public Papers and Addresses of Franklin D. Roosevelt, ed. Samuel I. Rosenman, 13 vols. New York: Random House, 1938.

Truman, Harry. The Public Papers of the Presidents of the United States, 8 vols. Washington, D.C.: Government Printing Office, 1961.

Washington, Booker T. The Booker T. Washington Papers, ed. Louis R. Harlan, 14 vols. Urbana: University of Illinois Press, 1974

Newspapers

ADIHGRAM

L'Assaut

Ayiti Ekran

Caribbean Action

Le Continental

Le Courrier

Haïti Business

Haiti Sun
Haiti Times

Impact

L'Information

Libération

Le Matin

The Miami Herald

Miroir

Le Moniteur
Newsweek

Le Nouveau Monde

Le Nouvelliste

Le Petit Samedi Soir

La Phalange

The New York Times 
Books and Articles

Abbott, Elizabeth. Haiti: The Duvaliers and Their Legacy. New York: McGraw Hill, 1988.

—. Haiti: A Shattered Nation. New York: Overlook, 2011.

Abrams, Charles. Housing in the Modern World. London: Faber \& Faber, 1964.

—. Man's Struggle for Shelter in an Urbanizing World. Cambridge: MIT Press, 1964.

The City is the Frontier. New York: Harper \& Row, 1965.

Adas, Michael. Machines as the Measure of Men: Science, Technology, and Ideologies of Western Dominance. Ithaca: Cornell University Press, 1989.

_. Dominance by Design: Technological Imperatives and America's Civilizing Mission. Cambridge: Belknap Press, 2006.

Akin, William E. Technocracy and the American Dream: The Technocrat Movement, 1900-1941. Berkeley: University of California Press, 1977.

Alexis, Gérald. Hippolyte: Module 30. Port-au-Prince: Imp. II, 1993.

Alexis, Jacques Stephan. General Sun, My Brother, translated by Carrol F. Coates. Charlottesville: University Press of Virginia, 1999. Originally published in 1955.

Ammon, Francesca Russello. Bulldozer: Demolition and Clearance of Postwar Landscape. New Haven: Yale University Press, 2016.

Anderson, Carol. Eyes Off the Prize: The United Nations and the African American Struggle for Human Rights, 1944-1955. New York: Cambridge University Press, 2003.

Anderson, James D. The Education of Blacks in the South, 1860-1935. Chapel Hill: University of North Carolina Press, 1988.

Andrew III, John A. Lyndon Johnson and the Great Society. Chicago: Ivan R. Dee, 1999.

Anglade, Mireille Neptune. "Haïti: le travail des femmes ou comment s'enrichissent les hommes." Thèse de doctorat: Sorbonne Nouvelle, 1986. 
L L'autre moitié du développement: a propos du travail des femmes en Haïti. Pétionville: Editions des Alizés, 1986.

Antoine, Charles. Quelques considerations sur le milieu rural: à deseaux, une experience de développement communautaire dans la Vallée de l'Artibonite. Port-au-Prince: Imp. N.A. Théodore, 1959.

Appy, Christian G., ed. Cold War Constructions: The Political Culture of United States Imperialism, 1945-1966. Amherst: University of Massachusetts Press, 2000.

Aptheker, Herbert, ed. Marxism and Christianity. New York: Humanities Press, 1968.

Aristide, Achille. Culture, civilisation et développement. Port-au-Prince: Henri Deschamps, 1978.

Aristide, Jean-Bertrand. Sembrando utopia: reportajes y conversaciones con Jean-Bertrand Aristide, edited by Sergio Ferrai. Managua: Editiones Nicarao, 1992.

—. Théologie et politique. Montréal: CIDIHCA, 1992.

—. Névrose vétéro-testamentaire. Montréal: CIDIHCA, 1994.

Aristide, Jean-Bertrand with Christophe Wargny. Tout homme est un homme. Paris: Editions du Seuil, 1992.

Armytage, W.H.G. Heavens Below: Utopian Experiments in England, 1560-1960. New York: Routledge, 2006. Originally published in 1961.

- The Rise of the Technocrats: A Social History. New York: Routledge, 2006.

Arndt, H.W. The Rise and Fall of Economic Growth: A Study in Contemporary Thought. Melbourne: Longman Cheshire, 1978.

Arnold, Joseph L. The New Deal in the Suburbs: A History of the Greenbelt Town Program. Columbus: Ohio State University Press, 1971.

Arthus, Wien Weibrert. "L'aide internationale peut ne pas marcher: évaluation des relations américano-haïtiennes au regard de l'Alliance pour le Progrès, 1961-1963." Journal of Haitian Studies 17, no. 1 (Spring 2011): $155-77$. 
_. "The Alliance for Progress: A Case Study of Failure of International Commitments to Haiti." In The Idea of Haiti: Rethinking Crisis and Development, edited by Millery Polyné. Minneapolis: University of Minnesota Press, 2013.

—. Duvalier à l'ombre de la guerre froide: les dessous de la politique étrangère d'Haïti, 1957-1963. Port-au-Prince: Imp. S.A., 2014.

Auguste, Marcel B. La république d'Haïti et la deuxième guerre mondiale. Québec: AGMV Marquis, 1988.

Ball, Terence. "The Politics of Social Science in Postwar America." In Recasting America: Culture and Politics in the Age of Cold War, edited by Larry May, 61-75. Chicago: University of Chicago Press, 1989.

Barnhisel, Greg. Cold War Modernism: Art, Literature, and American Cultural Diplomacy. New York: Columbia University Press, 2015.

Barthélemy, Gérard. L'univers rural haïtien: le pays en dehors. Paris: L'Harmattan, 1990.

Bates, Toby Glenn. The Reagan Rhetoric: History and Memory in 1980s America. DeKalb: Northern Illinois University Press, 2011.

Bauman, Zygmunt. Socialism: The Active Utopia. New York: Holmes and Meier, 1976.

—. Liquid Modernity. New York: Polity Press, 2000.

_ "Utopia with No Topos." History of the Human Sciences 16, no. 1 (2003): 11-25.

Bazin, Marc L. Dossier de presse. Port-au-Prince: MIDH, 1987.

_ "Democratic Transition in Haiti." The Yale Journal of International Law 13, no. 2 (Summer 1988): 303-12.

—. Discours et messages, vol. 1, Le défi démocratique. Port-au-Prince: Henri Deschamps, 1989.

—. Discours et messages, vol. 2, Construire ensemble. Port-au-Prince: Henri Deschamps, 1990.

_. Miser sur l'homme: une vision globale pour une nouvelle société. Port-auPrince: MIDH, 1990.

—. Haïti 92: démocratie sous pression. Port-au-Prince: Henri Deschamps, 1995. 
- Sortir de l'impasse: démocratie, réformes et développement. Port-auPrince: MIDH, 2006.

—. Des idées pour l'action. Port-au-Prince: Imp. II, 2008.

Bazin, Marc L. with Frantz Duval and Jobnel Pierre. D'où viennent les idées de Marc L. Bazin? Port-au-Prince: Imp. II, 2008.

Beauchesne, Kim and Alessandra Santos, eds. The Utopian Impulse in Latin America. New York: Palgrave Macmillan, 2011.

Beevers, Robert. The Garden City Utopia: A Critical Biography of Ebenezer Howard. New York: St. Martin's Press, 1988.

Beitz, Charles R. The Idea of Human Rights. New York: Oxford University Press, 2009.

Bell, Daniel. The End of Ideology: On the Political Exhaustion of Political Ideas in the Fifties. New York: The Free Press, 1960.

Bellamy, Edward. Looking Backward, 2000-1887. New York: Oxford University Press, 2009. Originally published in 1888.

_ Equality. Rockville: Wildside Press, 2010. Originally published in 1897.

Bellegarde-Smith, Patrick. "Class Struggle in Contemporary Haitian Politics: An Interpretive Study of the Campaign of 1957." Journal of Caribbean Studies 2, no. 1 (Spring 1981): 109-27.

- "Haitian Social Thought in the Nineteenth Century: Class Formation and Westernization." Phylon 42, no. 3 (Fall 1981): 233-44.

Belmonte, Laura A. Selling the American Way: US Propaganda and the Cold War. Philadelphia: University of Pennsylvania Press, 2010.

Benjamin, Dumas. Les conditions du développement économique d'Haïti. Portau-Prince: Presses Nationales d'Haïti, 1977.

Benoît, Pierre. Cent cinquante ans de commerce extérieur d'Haïti, 1804-1954. Port-au-Prince: Henri Deschamps, 1954.

Bernardin, Ernst A. L'espace rural haïtien: bilan de 40 ans d'exécution des programmes nationaux et internationaux de développement, 1950-1990. Paris: L'Harmattan, 1993.

Bernstein, Michael A. and Allen Hunter. "The Cold War and Expert Knowledge." Radical History Review 21, no. 63 (Fall 1995): 1-6. 
Bess, Michael. Realism, Utopia, and the Mushroom Cloud. Chicago: University of Chicago Press, 1993.

Besse, Susan K. Restructuring Patriarchy: The Modernization of Gender Inequality in Brazil, 1914-1940. Chapel Hill: University of North Carolina Press, 1996.

Bethell Leslie and lan Roxborough. "The Impact of the Cold War on Latin America." In Origins of the Cold War: An International History, edited by Melvyn P. Leffler and David Painter, 293-316. New York: Routledge, 1994.

Biles, Roger. The Fate of Cities: Urban America and the Federal Government, 1945-2000. Lawrence: University Press of Kansas, 2011.

Blancpain, François. Haïti et les Etats-Unis: histoire d'une occupation. Paris: L'Harmattan, 1999.

_. Un siècle de relations financères entre Haïti et la France, 1825-1922. Paris: L'Harmattan, 2003.

Bloch, Ernst. The Principle of Hope, 3 vols., translated by Neville Plaice, Stephen Plaice, and Paul Knight. Cambridge: MIT Press, 1986. Originally published in 1959.

- Atheism in Christianity: The Religion of the Exodus and the Kingdom, translated by J.T. Swann. New York: Herder \& Herder, 1972. Originally published in 1968.

- The Spirit of Utopia, translated by Anthony A. Nassar. Stanford: Stanford University Press, 2000. Originally published in 1964.

Bodmer, Beatriz Pastor. El jardín y el peregrino: el pensamiento utópico en América Latina, 1492-1695. Ciudad Universitaria: Universidad Nacional Autónoma de México, 1999.

Bonhomme, Colbert. Logement ouvrier populaire. Port-au-Prince: Les Presses de la Cie. Litho. d'Haïti, 1958.

Bordes, Ary. Evolution des sciences de la santé et de l'hygiène publique en Haïti. Port-au-Prince: Centre d'Hygiène Familiale, 1979.

_. Un médecin raconte: une vie, une carrière. Port-au-Prince: Henri Deschamps, 1989.

Haïti: médecine et santé publique sous l'occupation américaine, 19151934. Port-au-Prince: Henri Deschamps, 1992. 
Bordes, Ary and Andrea Couture. For the People, For a Change. Boston: Beacon Press, 1978.

Borgwardt, Elizabeth. A New Deal for the World: America's Vision for Human Rights. Cambridge: Belknap Press, 2005.

Borstelmann, Thomas. The Cold War and the Color Line: American Race Relations in the Global Arena. Cambridge: Harvard University Press, 2001.

Boyer, Paul. Urban Masses and Moral Order in America, 1820-1920. Cambridge: Harvard University Press, 1978.

Brands, Hal. Latin America's Cold War. Cambridge: Harvard University Press, 2010.

Brière, Jean-François. Haïti et la France, 1804-1848: le rêve brisé. Paris: Karthala, 2008.

Briggs, Laura. Reproducing Empire: Race, Sex, Science, and US Imperialism in Puerto Rico. Berkeley: University of California Press, 2002.

Brinkley, Alan. "The Illusion of Unity in Cold War Culture." In Rethinking Cold War Culture, co-edited by Peter Kuznick and James Gilbert, 61-73.

Washington, D.C.: Smithsonian, 2010.

Brisson, Gérald and Gérard Pierre-Charles. Les relations agraires dans l'Haïti contemporaine. Port-au-Prince: N.p., 1968.

Brodwin, Paul. Medicine and Morality in Haiti. New York: Cambridge University Press, 1996.

Brouard, Carl. "Paradis perdu." La Revue Indigène 1, no. 5 (Jan. 1928): 202.

_. "Les Griots." Les Griots 1, no. 1 (Jul.-Sep. 1938): 17.

Brown, Kate. Plutopia: Nuclear Families, Atomic Cities, and the Great Soviet and American Plutonium Disasters. New York: Oxford University Press, 2015.

Bruce, Susan, ed. Three Early Modern Utopias: Utopia, New Atlantis, and the Island of Pines. New York: Oxford University Press, 2009.

Brunschwig, Jacques and Geoffrey E.R. Lloyd. Greek Thought: A Guide to Classical Knowledge. Cambridge: Belknap Press, 2000.

Buck-Morss, Susan. Dreamworld and Catastrophe: The Passing of Mass Utopia in East and West. Cambridge: MIT Press, 2000. 
Bulmer-Thomas, Victor. The Economic History of the Caribbean since the Napoleonic Wars. New York: Cambridge University Press, 2014.

Burdick, Eugene and William Lederer. The Ugly American. New York: Norton, 1958.

Burgin, Angus. The Great Persuasion: Reinventing Free Markets since the Depression. Cambridge: Harvard University Press, 2012.

Burnard, Trevor and John D. Garrigus. The Plantation Machine: Atlantic Capitalism in French Saint-Domingue and British Jamaica. Philadelphia: University of Pennsylvania Press, 2016.

Bury, Robert Israël. "Organisation de Développement de la Vallée de l'Artibonite." In Développement rural en Haïti et dans la Caraïbe, edited by J.B. Roumain. Port-au-Prince: Imp. Rodriguez, 1980.

Buss, Terry F. and Adam Gardner. Haiti in the Balance: Why Foreign Aid Has Failed and What We Can Do About It. Washington, D.C.: Brookings Institution, 2008.

Buteau, Pierre and Lyonel Trouillot, eds. Le prix du Jean-Claudisme: arbitraire, parodie, désocializacion. Port-au-Prince: C3 Editions, 2013.

Bynum, W.F. The Western Medical Tradition: 1800-2000. New York: Cambridge University Press, 2006.

Callahan, North. TVA: Bridge Over Troubled Waters. New York: A.S. Barnes and Co., 1980.

Campbell, Wallace J. Here is Tomorrow: Consumer Cooperatives in America. New York: CLUSA, 1941.

Cardoso, Fernando Henrique and Enzo Faletto. Dependency and Development in Latin America, trans. Marjory Mattingly Urquidi. Berkeley: University of California Press, 1979.

Castaneda, Jorge G. Utopia Unarmed: The Latin American Left After the Cold War. New York: Vintage, 1994.

Castillo, Greg. Cold War on the Home Front: The Soft Power of Midcentury Design. Minneapolis: University of Minnesota Press, 2010.

Castor, Suzy. L'occupation américaine d'Haïti. Port-au-Prince: Henri Deschamps, 1987. 
_. "Refonder la nation haïtien." In Haïti aujourd'hui, Haïti demain: regards choisés, co-edited by Andrea Martinez, Pierre Beaudet, and Stephen Baranyi, 105-113. Ottawa: Presses de l'Univeristé d'Ottawa, 2011.

Castor, Suzy, Fritz Deshommes, and Laënnec Hurbon, eds. Haïti, réinventer l'avenir. Port-au-Prince: Editions de l'Université d'Etat d'Haïti, 2012.

Carlo A. Célius, ed. Le défi haïtien: économie, dynamique sociopolitique et migration. Paris: L'Harmattan, 2011.

Chandler, Jr., Alfred. The Visible Hand: The Managerial Revolution in American Business. Cambridge: Belknap Press, 1977.

Charles, Carolle. "Gender and Politics in Contemporary Haiti: The Duvalierist State, Transnationalism and the Emergence of a New Feminism, 19801990." Feminist Studies 21, no. 1 (Spring 1995): 135-64.

Chase, Stuart. Technocracy: An Interpretation. New York: John Day, 1933.

Chernus, Ira. Nuclear Madness: Religion and the Psychology of the Nuclear Age. Albany: State University of New York Press, 1991.

Chéry, Fréderic Gérald. Société, économie et politique en Haïti: la crise permanente. Port-au-Prince: Editions des Antilles, 2005.

Clapp, Gordon R. "The Tennessee Valley Authority." In Regionalism in America, edited by Merrill Jensen, 326-27. Madison: University of Wisconsin Press, 1951.

Clavin, Matthew J. Toussaint Louverture and the American Civil War: The Promise and Peril of a Second Haitian Revolution. Philadelphia: University of Pennsylvania Press, 2012.

Clinton, Bill. "Our Commitment to Haiti." Innovations 5, no. 4 (Fall 2010): 5.

Cohen, Lizabeth. A Consumer's Republic: The Politics of Mass Consumption in Postwar America. New York: Vintage, 2008.

Cohen-Cole, Jamie. The Open Mind: Cold War Politics and the Sciences of Human Nature. Chicago: University of Chicago Press, 2014.

Collier, David, ed. The New Authoritarianism in Latin America. Princeton: Princeton University Press, 1979.

Connelly, Matthew. "Seeing Beyond the State: The Population Control Movement and the Problem of Sovereignty." Past \& Present 195 (November 2006): 197-233. 
_ "To Inherit the Earth: Imagining World Population, From the Yellow Peril to the Population Bomb." Journal of Global History 1, no. 3 (November 2006): 299-319.

- Fatal Misconception: The Struggle to Control World Population. Cambridge: Belknap Press, 2008.

—. "The Cold War in the Longue Durée: Global Migration, Public Health, and Population Control." In The Cambridge History of the Cold War, co-edited by Melvyn P. Leffler and Odd Arne Westad, vol. 3, 466-88. New York: Cambridge University Press, 2010.

Corbusier. Towards a New Architecture. New York: Dover, 1986. Originally published in 1931.

Corvington, Georges. Port-au-Prince au cours des ans, 7 vols. Port-au-Prince: Henri Deschamps, 1972-1991.

Courlander, Harold. The Drum and the Hoe: Life and Lore of the Haitian People. Berkeley: University of California Press, 1960.

Cox, Ronald. "Private Interests and US Foreign Policy in Haiti and the Caribbean Basin." In Contested Social Orders and International Politics, edited by David Skidmore, 187-207. Nashville: Vanderbilt University Press 1997.

Crain, Edward E. Historic Architecture in the Caribbean Islands. Gainesville: University Press of Florida, 1994.

Crosby, Donald. God, Church, and Flag: Senator Joseph R. McCarthy and the Catholic Church, 1950-1957. Chapel Hill: University of North Carolina Press, 1978.

Cueto, Marcos. Cold War, Deadly Fevers: Malaria Eradication in Mexico, 19551975. Baltimore: Johns Hopkins University Press, 2007.

Cueto, Marcos. Medicine and Public Health in Latin America. New York: Cambridge University Press, 2014.

Cullather, Nick. The Hungry World: America's Cold War Battle Against Poverty in Asia. Cambridge: Harvard University Press, 2013.

Creese, Walter L. The Search for Environment: The Garden City Before and After. New Haven: Yale University Press, 1966.

- TVA's Public Planning: The Vision, the Reality. Knoxville: University of Tennessee Press, 1990. 
Culvahouse, Tim, ed. The Tennessee Valley Authority: Design and Persuasion. Princeton: Princeton Architectural Press, 2007.

Crossman, Richard, ed. The God that Failed. New York Columbia University Press, 2001. Originally published in 1950.

Dargent, Eduardo. Technocracy and Democracy in Latin America: The Experts Running Government. New York: Cambridge University Press, 2015.

Dash, J. Michael. Literature and Ideology in Haiti, 1915-1961. Totowa: Barnes and Noble Books, 1981.

—. Haiti and the United States: National Stereotypes and Literary Imagination. New York: St. Martin's Press, 1988.

Davies, Gareth. From Opportunity to Entitlement: The Transformation and Decline of Great Society Liberalism. Lawrence: University of Kansas Press, 1996.

De Grazia, Victoria. Irresistible Empire: America's Advance through 20th Century Europe. Cambridge: Belknap Press, 2006.

Dejean, Paul. Prélude à la liberté: panorama de la situation politique haïtienne après le 7 février 1986, du 15 août 1986 au 14 mars 1987. Port-au-Prince: Imp. Rodriguez, 1987.

Delbeau, Jean-Claude. Société, culture et médecine populaire traditionnelle. Port-au-Prince: Henri Deschamps, 1990.

Demeny, Paul. "Social Science and Population Policy." Population and Development Review 14, no. 3 (September 1988): 451-79.

Denis, Lorimer and François Duvalier. "Psychology ethnique et historique." Les Griots 1, no. 4 (April-June 1939): 473-502.

—. Problème des classes à travers l'histoire d'Haïti. Port-au-Prince: Imp. de l'Etat, 1958. Originally published in 1948.

Désinor, Carlo A. Il était un fois: Duvalier, Bosch et Kennedy, 1963. Port-auPrince: Imp. II, 1989.

Deshommes, Fritz. Vie chère et politique économique en Haïti. Port-au-Prince: Imp. II, 1992.

- Néo-libéralisme: crise économique et alternative de développement. Portau-Prince: N.p., 1993. 
- Décentralisation et collectivités territoriales en Haïti: un état des lieux. Port-au-Prince: Editions Cahiers Universitaires, 2004.

- Haïti: le nation écartelée entre "plan américain" et projet national. Port-auPrince: Editions Cahiers Universitaires, 2006.

Desrochers, Pierre and Christine Hoffbauer. "The Post War Intellectual Roots of the Population Bomb." Electronic Journal of Sustainable Development 1, no. 3 (Summer 2009): 37-61.

Detienne, Marcel and Jean-Pierre Vernaut. Cunning Intelligence in Greek Culture and Society, trans. Janet Lloyd. Atlantic Highlands: Humanities Press, 1978. Originally published in 1974.

DeWind, Josh and David Kinley III. Aiding Migration: The Impact of International Development Assistance on Haiti. Boulder: Westview Press, 1988.

Dezalay, Yves and Bryant Garth. The Internationalization of Palace Wars: Lawyers, Economists, and the Contest to Transform Latin American States. Chicago: University of Chicago Press, 2002.

Diederich, Bernard. Island of Fear: Hispaniola, 1960. Port-au-Prince: Henri Deschamps, 2010.

- Blood in the Sun: The Tyranny of Papa Doc Duvalier. Port-au-Prince: Henri Deschamps, 2010.

—. L'héritier: Jean-Claude Duvalier: 1971-1986. Port-au-Prince: Henri Deschamps, 2011.

— Fort Dimanche. Port-au-Prince: N.p., 2014.

-The Price of Blood: History of Repression and Rebellion in Haiti under François Duvalier, 1957-1961. Princeton: Markus Wiener, 2011.

- The Murderers Among Us: History of Repression and Rebellion in Haiti under Dr. François Duvalier, 1962-1971. Princeton: Markus Wiener, 2011.

Diederich, Bernard and Al Burt. Papa Doc: The Truth About Haiti Today. New York: McGraw-Hill, 1969.

Dillon, Elizabeth Maddock and Michael J. Drexler. The Haitian Revolution and the Early United States. Philadelphia: University of Pennsylvania Press, 2016.

Dodge, J. Robert. Cooperative Housing. Washington, D.C.: HUD, 1971. 
Donaldson, Peter J. Nature Against Us: The United States and the World Population Crisis, 1965-1980. Chapel Hill: University of North Carolina Press, 1990.

Donner, Wolf. Ayiti: potansyèl natirèl e dèvlopman. Fribourg: Komité EdiKréyòl, 1982.

Dore, Elizabeth and Maxine Molyneux, eds. Hidden Histories of Gender and the State in Latin America. Durham: Duke University Press, 2000.

Doret, Michel R. Le style gingerbread. Ornex-Maconnex: Editions Amon Râ, 1991.

Dorman, Robert. Revolt in the Provinces: The Regionalist Movement in America, 1920-1945. Chapel Hill: University of North Carolina Press, 1993.

Doura, Fred. Mondialisation: exclusion sociale et marginalisation des pays sousdéveloppés. Montréal: CIDHICA, 1998.

- Economie d'Haïti: dépendence, crises et développement, 3 vols. Montréal: Editions DAMI, 2003.

Douyon, Emerson, ed. Culture et développement en Haïti. Ottawa: Editions Leméac, Inc., 1972.

Douyon, Franz and Daniel Holly. Haïti de l'indépendence à la dependence. Paris: L'Harmattan, 2004.

Dowbiggin, Ian R. The Sterilization Movement and Global Fertility in the Twentieth Century. New York: Oxford University Press, 2008.

Dubois, Laurent. Avengers of the New World: The Story of the Haitian Revolution. Cambridge: Belknap Press, 2005.

Dubos, René Jules. The Dreams of Reason: Science and Utopias. New York: Columbia University Press, 1961.

Dudziak, Mary L. Cold War Civil Rights: Race and the Image of American Democracy. Princeton: Princeton University Press, 2000.

Duménil, Gérard and Dominique Lévy. Capital Resurgent: Roots of the Neoliberal Revolution. Cambridge: Harvard University Press, 2004.

Dun, James Alexander. Dangerous Neighbors: Making the Haitian Revolution in Early America. Philadelphia: University of Pennsylvania Press, 2016.

Dupuy, Alex. "Conceptualizing the Duvalier Dictatorship." Latin American Perspectives 15, no. 4 (Fall 1988): 105-114. 
- Haiti in the World Economy: Class, Race, and Underdevelopment since 1700. Boulder: Westview Press, 1989.

- The Prophet and Power: Jean-Bertrand Aristide, the International Community, and Haiti. Lanham: Rowman \& Littlefield, 2007.

- Haiti: From Revolutionary Slaves to Powerless Citizens. New York: Routledge, 2015.

Durand, Rony. Regards sur la croissance économique d'Haïti. Port-au-Prince: Imp. des Antilles, 1965.

—. Penser le développement. Port-au-Prince: Editions Fardin, 1979.

Duvalier, François. "Pour un humanisme totalitaire." Les Griots: la revue scientifique et littéraire d'Haïti 4, no. 1 (April-September 1939).

Dussel, Enrique. "Liberation Theology and Marxism." Rethinking Marxism 5, no. 3 (Fall 1992): 50-74.

Easterly, William. The Tyranny of Experts: Economists, Dictators, and the Forgotten Rights of the Poor. New York: Basic Books, 2013.

Eckes, Jr., Alfred E. and Thomas W. Zeiler, Globalization and the American Century. New York: Cambridge University Press, 2003.

Ehrlich, Paul and Anne Ehrlich. The Population Bomb. New York: Ballantine Books, 1968.

Ekbladh, David. The Great American Mission: Modernization and the Construction of an American World Order. Princeton: Princeton University Press, 2011.

Engelman, Peter C. A History of the Birth Control Movement in America. Santa Barbara: Praeger, 2011.

Engels, Frederic. Outline of a Critique of Political Economy. In The Collected Works of Karl Marx and Frederic Engels, vol. 3. London: Lawrence and Wishart, 1997. Originally published in 1844.

- The Condition of the Working Class in England in 1844. In The Collected Works of Karl Marx and Frederic Engels, vol. 4. London: Lawrence and Wishart, 1997. Originally published in 1845.

- Socialism: Utopian and Scientific. In The Collected Works of Karl Marx and Frederic Engels, vol. 24. London: Lawrence and Wishart, 1997. Originally published in 1883. 
Engerman, David C. Modernization from the Other Shore: American Intellectuals and the Romance of Russian Development. Cambridge: Harvard University Press, 2004.

Engerman, David C., Nils Gilman, Mark H. Haefele, and Michael E. Latham, eds. Staging Growth: Modernization, Development, and the Global Cold War. Amherst: University of Massachusetts Press, 2003.

Erdim, Burak. "Middle East Technical University and Revolution: Development Planning and Architectural Education During the Cold War, 1950-1962." Ph.D. Dissertation: University of Virginia, 2012.

Escobar, Arturo. Encountering Development: The Making and Unmaking of the Third World. Princeton: Princeton University Press, 1995.

Estimé, Lucienne H., ed. Dumarsais Estimé: dialogue avec mes souvenirs. Portau-Prince: Editions Mémoire, 2001.

Etienne, Sauveur Pierre. Haïti: l'invasion des ONG. Montréal: CIDIHCA, 1997.

—. Haïti: misère de la démocratie. Paris: L'Harmattan, 1999.

—. L'énigme haïtienne: échec de l'état moderne en Haïti. Montréal: Presse de l'Université de Montréal, 2007.

Eurich, Nell. Science in Utopia: A Mighty Design. Cambridge: Harvard University Press, 1967.

Farmer, Paul. "Sending Sickness: Sorcery, Politics, and Changing Concepts of AIDS in Rural Haiti." Medical Anthropology Quarterly 4, no. 1 (March 1990): 6-27.

- AIDS and Accusation: Haiti and the Geography of Blame. Berkeley: University of California Press, 1992.

—. Haiti: After the Earthquake. New York: Public Affairs, 2012.

Fass, Simon M. "The St. Martin Project: A Decade of Pain and Progress in the Evolution of an Urban Development Institution." In Politics, Projects, and People: Institutional Development in Haiti, co-edited by Derick W. Brinkerhoff and Jean-Claude Garcia-Zamor. New York: Praeger, 1986.

—. Political Economy in Haiti: The Drama of Survival. New Brunswick: Transaction Publishers, 1988.

Fatton, Jr., Robert. Haiti's Predatory Republic: The Unending Transition to Democracy. Boulder: Lynne Rienner, 2002. 
—. The Roots of Haitian Despotism. Boulder: Lynne Rienner, 2007.

_ "The Rise, Fall, and Second Coming of Jean-Bertrand Aristide." In Haitian History: New Perspectives, edited by Alyssa Goldstein Sepinwall, 294311. New York: Routledge, 2012.

—. Haiti: Trapped in the Outer Periphery. Boulder: Lynne Rienner, 2013.

Ferguson, James. Papa Doc, Baby Doc: Haiti and the Duvaliers. New York: B. Blackwell,1988.

Fick, Carolyn. The Making of Haiti: The Saint Domingue Revolution from Below. Knoxville: University of Tennessee Press, 1990.

Findlay, Eileen J. Suárez. Imposing Decency: The Politics of Sexuality and Race in Puerto Rico, 1870-1920. Durham: Duke University Press, 1999.

Firmin, Anténor La république d'Haïti et ses relations économiques avec la France. Paris: F. Pichon, 1892.

Fischer, Sibylle. Modernity Disavowed: Haiti and the Cultures of Slavery in the Age of Revolution. Durham: Duke University Press, 2004.

Fishman, Robert. Urban Utopias in the Twentieth Century: Ebenezer Howard, Frank Lloyd Wright, and Le Corbusier. New York: Basic Books, 1977.

Fishman, Robert, ed. The American Planning Tradition: Culture and Policy. Baltimore: Johns Hopkins University Press, 2000.

Fleischmann, Ulrich. Aspekte der sozialen und politischen Entwicklung Haitis. Hamburg: Institut für lberoamerika-Kunde, 1971.

Foucault, Michel. Power/Knowledge. New York: Pantheon, 1980.

- The Birth of the Clinic: An Archaeology of Medical Perception, translated by A.M. Sheridan Smith. New York: Vintage, 1994. Originally published in 1963.

- The History of Sexuality, translated by Robert Hurley, 3 vols. New York: Vintage, 2012. Originally published between 1976 and 1984.

- The Birth of Biopolitics: Lectures at the Collège de France, 1978-1979, edited by Arnold I. Davidson, translated by Graham Burchell. Basingstoke: Palgrave Macmillan, 2008.

Fouchard, Jean. "Quand Haïti exportait la liberté." Revue de la Société Haïtienne d'Histoire et de Géographie, no. 143 (1984): 42-45. 
Francisque, Edouard. Perspectives du développement économique en Haïti. Port-au-Prince: Henri Deschamps, 1968.

Frank, André Gunder. Capitalism and Underdevelopment in Latin America: Historical Studies of Chile and Brazil. New York: Monthly Review Press, 1969.

Frank, Robert H. The Darwin Economy: Liberty, Competition, and the Common Good. Princeton: Princeton University Press, 2011.

Fréguin, Sandrine and Sophie Devienne. "Libéralisation économique et marginalisation de la paysannerie en Haïti: le cas de l'arcahaie." Revue tiers monde 47, no. 187 (July-September 2006): 621-42.

Freud, Sigmund. The Interpretation of Dreams. New York: Basic Books, 2010. Originally published in 1900.

Friedman, Max Paul. "Retiring the Puppets, Bringing Latin America Back In," Diplomatic History 27, no. 5 (November 2003): 621-36.

Friedman, Milton. Capitalism and Freedom. Chicago: University of Chicago Press, 1962.

Fowler, Carolyn. A Knot in the Thread: The Life and Work of Jacques Roumain. Washington, D.C.: Howard University Press, 1980.

Fukuyama, Francis. The End of History and the Last Man. New York: The Free Press, 1992.

Gaillard, Gusti-Klara. L'expérience haïtienne de la dette extérieure ou une production caféière pillée, 1875-1915. Port-au-Prince: Henri Deschamps, 1990.

Gaillard, Roger. Le blanques débarquent. 7 vols. Port-au-Prince: Imp. Natal, 1973-1981.

- La république exterminatrice, vol. 7, Antoine Simon ou la modification, 1908-1911. Port-au-Prince: Imp. Natal, 1998.

Ganjavie, Amir. "The Role of Utopian Projects in Urban Design." Utopian Studies 25, no. 1 (2014): 125-49.

Gardner, Lloyd C. Imperial America: American Foreign Policy since 1898. New York: Harcourt Brace, 1976.

Garrigus, John D. Before Haiti: Race and Citizenship in French Saint-Domingue. New York: Palgrave Macmillan, 2006. 
Garrity, Monique P. "The Assembly Industries in Haiti: Causes and Effects." Journal of Caribbean Studies 2, no. 1 (Spring 1981): 25-37.

Gaspard, Fritzner. Haïti: ajustement structurel et problèmes politiques. Paris: L'Harmattan, 1998.

Geddes, Patrick and Victor Branford. The Coming Polity. London: Williams \& Norgate, 1919.

_. Cities in Evolution. New York: Howard Fertig, 1968.

Geggus, David Patrick. Haitian Revolutionary Studies. Bloomington: Indiana University Press, 2002.

Geoghegan, Vincent. Utopianism and Marxism. New York: Methuen, 1987.

Georges-Pierre, Anthony. Dumarsais Estimé: l'homme, l'œuvre et les idées. Port-au-Prince: Imp. S.A., 2012.

Gershenhorn, Jerry. Melville J. Herskovits and the Racial Politics of Knowledge. Lincoln: University of Nebraska Press, 2004.

Gilbert, Jess. Planning Democracy: Agrarian Intellectuals and the Intended New Deal. New Haven: Yale University Press, 2015.

Gilman, Nils. Mandarins of the Future: Modernization Theory in Cold War America. Baltimore: Johns Hopkins University Press, 2003.

Girard, Philippe. Clinton in Haiti: The 1994 US Invasion of Haiti. New York: Palgrave Macmillan, 2004.

- Paradise Lost: Haiti's Tumultuous Journey from Pearl of the Caribbean to Third World Hotspot. New York: Palgrave Macmillan, 2005.

Girardi, Giulio. On Marxism and Christianity, translated by Kevin Traynor. New York: Macmillan, 1968. Originally published in 1968.

Girault, Christian. Le commerce du café en Haïti. Paris: Centre National de la Recherche Scientifique, 1981.

Goetz, Edward G. New Deal Ruins: Race, Economic Justice, and Public Housing Policy. Ithaca: Cornell University Press, 2013.

Goldstein, Alyosha. Poverty in Common: The Politics of Community Action During the American Century. Durham: Duke University Press, 2012.

Gravette, Andrew. Architectural Heritage of the Caribbean. Princeton: Markus Wiener Publishers, Inc., 2000. 
Greene, Graham. The Comedians. London: Bodley Head, 1966.

Grandin, Greg. The Last Colonial Massacre: Latin America in the Cold War. Chicago: University of Chicago Press, 2004.

Greene, Ronald Walter. Malthusian Worlds: US Leadership and the Governing of the Population Crisis. Boulder: Westview Press, 1999.

Greenbaum, Susan D. Blaming the Poor: The Long Shadow of the Moynihan Report. New Brunswick: Rutgers University Press, 2015.

Greenhalgh, Susan. "The Social Construction of Population Science: An Intellectual, Institutional and Political History of Twentieth-Century Demography." Comparative Studies in Society and History 38, no. 1 (January 1966): 22-66.

Grunwald, Joseph, Leslie Delatour, and Carl Voltaire. "Foreign Assembly in Haiti." In The Global Factory: Foreign Assembly in International Trade. Washington, D.C.: Brookings Institution, 1984.

Gunn, T. Jeremy. Spiritual Weapons: The Cold War and the Forging of an American National Religion. Westport: Praeger, 2009.

Gutiérrez, Gustavo. A Theology of Liberation: History, Politics, and Salvation, translated by Caridad Inda and John Eagleson. Maryknoll: Orbis, 1988. Originally published in 1971.

Hall, Peter. Cities of Tomorrow: An Intellectual History of Urban Planning and Design in the Twentieth Century. Oxford: Blackwell, 2002. Originally published in 1988.

Hallward, Peter. Damming the Flood: Haiti and the Politics of Containment. London: Verso, 2007.

Hansen, Randall and Desmond King. Sterilized by the State: Eugenics, Race, and the Population Scare in Twentieth-Century North America. New York: Cambridge University Press, 2013.

Hanska, Jan. Reagan's Mythical America: Storytelling as Political Leadership. New York: Palgrave Macmillan, 2012.

Harrington, Michael. The Other America: Poverty in the United States. New York: Touchstone, 1997. Originally published in 1962.

Harrison, Harry. Make Room! Make Room! New York: Orb, 2008. Originally published in 1966. 
Harvey, David. A Brief History of Neoliberalism. New York: Oxford University Press, 2007.

Hayek, Friedrich A. The Road to Serfdom. Chicago: University of Chicago Press, 2007. Originally published in 1944.

Hayward, Steven F. The Age of Reagan: The Conservative Counterrevolution, 1980-1989. New York: Crown Forum, 2009.

Hector, Cary and Hérard Jadotte, eds. Haïti et l'après-Duvalier, 2 vols. Port-auPrince: Henri Deschamps, 1991.

Hector, Michel. Syndicalisme et socialisme en Haïti, 1932-1970. Port-au-Prince: Henri Deschamps, 1987.

Heinl, Robert Debs and Nancy Gordon Heinl. Written in Blood: The Story of the Haitian People, 1492-1971. Lanham: University Press of America, 2005. Originally published in 1978.

Henderson, A. Scott. Housing and the Democratic Ideal: The Life and Thought of Charles Abrams. New York: Columbia University Press, 2000.

Herbert, John D. and Alfred P. Van Huyck, eds. Urban Planning in the Developing Countries. New York: Praeger, 1968.

Herskovits, Melville. Life in a Haitian Valley. New York: Knopf, 1937.

Herzog, Jonathan P. The Spiritual-Industrial Complex: America's Religious Battle Against Communism in the Early Cold War. New York: Oxford University Press, 2011.

Hilaire, Sebastien. Le prix d'une agriculture minière. Port-au-Prince: Imp. Natal, 1995.

Hixon, Walter L. Parting the Curtain: Propaganda, Culture, and the Cold War, 1945-1961. New York: St. Martin's Press, 1997.

Hobsbawm, Eric. "Goodbye to All That." In After the Fall: The Failure of Communism and the Future of Socialism, edited by Robin Blackburn, 11526. London: Verso, 1991.

Hoffman, Elizabeth Cobbs. All You Need Is Love: The Peace Corps and the Spirit of the 1960s. Cambridge: Harvard University Press, 2000.

Holloway, Mark. Heavens on Earth: Utopian Communities in America, 16901880. New York: Dover Publications, 1966.

Holly, Marc. Agriculture in Haiti. New York: Vantage, 1955. 
Hölscher, Lucian. “Utopie.” Utopian Studies 7, no. 2 (1996): 1-2.

Honorat, Jean Jacques. Enquête sur le développement. Port-au-Prince: Imp. Centrale, 1974.

—. Le manifete du dernier monde. Port-au-Prince: Henri Deschamps, 1980.

_ . "Le paysan haïtien, hier et aujourd'hui." In Développement rural en Haïti et dans la Caraïbe, edited by the Université d'Etat d'Haïti, Faculté d'Ethnologie. Port-au-Prince: Imp. M. Rodriguez, 1980.

Hopenhayn, Martín. "Postmodernism and Neoliberalism in Latin America." In The Postmodernism Debate in Latin America, co-edited by John Beverly, José Oviedo, and Michael Aronna, 93-109. Durham: Duke University Press, 1995.

- No Apocalypse, No Integration: Modernism and Postmodernism in Latin America, translated by Cynthia Margarita Tompkins and Elizabeth Rosa Horan. Durham: Duke University Press, 2001.

Horkheimer, Max and Theodore W. Adorno. Dialectic of Enlightenment, translated by Edmund Jephcott. Stanford: Stanford University Press, 2002. Originally published in 1944.

Horowitz, Irving Louis. Ideology and Utopia in the United States, 1956-1976. New York: Oxford University Press, 1977.

Horton, Jr., Forest. The Technocrats. New York: Leisure Books, 1980.

Howard, Ebenezer. To-morrow: A Peaceful Path to Real Reform. London: Swan Sonnenschein, 1898.

Hubbard, Preston. Origins of the TVA: The Muscle Shoals Controversy, 19201932. New York: W.W. Norton \& Company, 1961.

Hunt, Lynn. Inventing Human Rights: A History. New York: W.W. Norton \& Company, 2007.

Hunt, Michael. Ideology and US Foreign Policy. New Haven: Yale University Press, 1987.

Hurbon, Laënnec. Culture et dictature en Haïti: l'imaginaire sous contrôle. Portau-Prince: Henri Deschamps, 1987.

_. Ernst Bloch: utopie et espérance. Paris: Editions du Cerf, 1974.

—. La barbare imaginaire. Port-au-Prince: Henri Deschamps, 1987. 
—. Religions et lien social: l'église et l'état moderne en Haïti. Paris: Cerf, 2004.

Ikenberry, G. John. Liberal Leviathan: The Origins, Crisis, and Transformation of the American World Order. Princeton: Princeton University Press, 2011.

Immerwahr, Daniel. Thinking Small: The United States and the Lure of Community Development. Cambridge: Harvard University Press, 2015.

Inboden, William. Religion and American Foreign Policy, 1945-1960: The Soul of Containment. New York: Cambridge University Press, 2010.

Jacoby, Russell. The End of Utopia: Politics and Culture in an Age of Apathy. New York: Basic Books, 1999.

James, C.L.R. The Black Jacobins: Toussaint L'Ouverture and the San Domingo Revolution. New York: Random House, 1963.

Jameson, Frederic. Postmodernism, Or, the Cultural Logic of Late Capitalism. Durham: Duke University Press, 1991.

- Archaeologies of the Future: The Desire Called Utopia and Other Science Fictions. New York: Verso, 2007.

Joaquim, Benoît. "Le néo-colonialisme à l'essai: la France et l'indépendance d'Haïti." La Pensée, no. 156 (1971): 35-51.

_Les racines de sous développement en Haïti. Port-au-Prince: Henri Deschamps, 1979.

Johnson, David K. The Lavender Scare: The Cold War Persecution of Gays and Lesbians in the Federal Government. Chicago: University of Chicago Press, 2006.

Joint, Louis Auguste, Education populaire en Haïti: ti kominote legliz. Paris: L'Harmattan, 1996.

Jones, Daniel Stedman. Masters of the Universe: Hayek, Friedman, and the Birth of Neoliberal Politics. Princeton: Princeton University Press, 2012.

Jones, Geoffrey. Multinationals and Global Capitalism from the Nineteenth Century to the Twenty-First Century. New York: Oxford University Press, 2005.

Jordon, John M. Machine-Age Ideology: Social Engineering and American Liberalism, 1891-1939. Chapel Hill: University of North Carolina Press, 1994. 
Jordy, William. "Symbolic Essence" and Other Writings on Modern Architecture and American Culture. New Haven: Yale University Press, 2005.

Joseph, Gilbert M. "Close Encounters: Toward a New Cultural History of USLatin America Relations." In Close Encounters of Empire: Writing the Cultural History of US-Latin America Relations, co-edited by Joseph, Catherine C. Legrand, and Ricardo D. Salvatore, 3-46. Durham: Duke University Press, 1998.

Joseph, Gilbert M. and Daniela Spencer, eds. In From the Cold: Latin America's New Encounter with the Cold War. Durham: Duke University Press, 2008.

Karabell, Zachary. Architects of Intervention: The United States, the Third World, and the Cold War, 1945-1962. Baton Rouge: Louisiana State University Press, 1999.

Kirby, Dianne. Religion and the Cold War. New York: Palgrave Macmillan, 2013.

Klein, Naomi. The Shock Doctrine: The Rise of Disaster Capitalism. New York: Macmillan, 2007.

Klemek, Christopher. The Transatlantic Collapse of Urban Renewal: Postwar Urbanism from New York to Berlin. Chicago: University of Chicago Press, 2011.

Klingensmith, Daniel. "One Valley and a Thousand:" Dams, Nationalism, and Development. New York: Oxford University Press, 2007.

Kolko, Gabriel. Confronting the Third World: United States Foreign Policy, 19451980. New York: Pantheon, 1988.

Krehm, William. Democracies and Tyrannies of the Caribbean in the 1940s. Toronto: Lugus Libros, 1999.

Krenn, Michael L. Fall-Out Shelters for the Human Spirit: American Art and the Cold War. Chapel Hill: University of North Carolina Press, 2005.

Kropotkin, Peter. Mutual Aid: A Factor of Evolution. London: William Heinemann, 1902.

Krueckeberg, Donald A., ed. The American Planner: Biographies and Recollections. New York: Methuen, 1983.

Kumar, Krishan. Utopianism. Minneapolis: University of Minnesota Press, 1991.

LaFeber, Walter. Inevitable Revolutions: The United States in Central America. New York: W.W. Norton \& Company, 1983. 
Lamothe, Camille. Le mouvement coopératif et la question sociale. Port-auPrince: Imp. de l'Etat, 1954.

- Cinq rapports sur le mouvement coopératif français et suisse. Port-auPrince: Imp. de l'Etat, 1954.

- Contribution à la vulgarisation de la pensée cooperative. Port-au-Prince: Imp. de l'Etat, 1958.

Largey, Michael. Vodou Nation: Haitian Art Music and Cultural Nationalism. Chicago: University Press of Chicago, 2006.

Lasky, Melvin J. Utopia and Revolution. Chicago: University of Chicago Press, 1976.

Lassiter, Matthew D. The Silent Majority: Suburban Politics in the Sunbelt South. Princeton: Princeton University Press, 2007.

Latham, Michael E. Modernization as Ideology: American Social Science and "Nation-Building" in the Kennedy Era. Chapel Hill: University of North Carolina Press, 2000.

- The Right Kind of Revolution: Modernization, Development, and US Foreign Policy from the Cold War to the Present. Ithaca: Cornell University Press, 2010.

—. "The Cold War in the Third World, 1963-1975." In The Cambridge History of the Cold War, co-edited by Melvyn P. Leffler and Odd Arne Westad, vol. 2, 258-80. New York: Cambridge University Press, 2010.

Lauren, Paul Gordon. The Evolution of International Human Rights: Visions Seen. Philadelphia: University of Pennsylvania Press, 1998.

Leconte, Frantz-Antoine, ed. En grandissant sous Duvalier: l'agonie d'un étatnation. Paris: L'Harmattan, 1999.

Lemoine, Patrick. Fort-Dimanche, Fort la Mort. Montréal: CIDIHCA, 1996.

Léon, Rulx. Pratique médicale à St.-Domingue. Paris: Presses Modernes, 1928.

Levine, Daniel H. Popular Voices in Latin American Catholicism. Princeton: Princeton University Press, 1992.

Levitas, Ruth. "New Right Utopias." Radical Philosophy 15, no. 39 (Spring 1985): 2-9. 
_. "Competition and Compliance: The Utopias of the New Right." In The Ideology of the New Right, edited by Levitas, 80-106. Cambridge: Polity Press, 1986.

The Concept of Utopia. New York: Peter Lang, 2010. Originally published in 1990.

_. "Educated Hope: Ernst Bloch on Abstract and Concrete Utopia," in Not Yet: Reconsidering Ernst Bloch, co-edited by Jamie Owen Daniel and Tom Moylan, 65-79. New York: Verso, 1997.

Lewis, Carolyn Herbst. Prescription for Heterosexuality: Sexual Citizenship in the Cold War Era. Chapel Hill: University of North Carolina Press, 2013.

Lewis, Oscar. Five Families: Mexican Case Studies in the Culture of Poverty. New York: Basic Books, 1975 Originally published in 1959.

- La Vida: A Puerto Rican Family in the Culture of Poverty-San Juan and New York. New York: Random House, 1966.

Lewis, Pericles. The Cambridge Introduction to Modernism. Cambridge: Cambridge University Press, 2007.

Leyburn, James G. The Haitian People. New Haven: Yale University Press, 1941.

Ligonde, François-Wolff. L'enfant, la famille, la société haïtienne. Port-au-Prince: Imp. de La Phalange, 1980.

Lilienthal, David E. TVA: Democracy on the March. New York: Harper \& Row, 1953. Originally published in 1944.

Locher, Uli. "Urban Bias in in Haiti." Journal of Haitian Studies 2, no. 1 (Spring 1996): 87-108.

Logan, George. The Meaning of More's Utopia. Princeton: Princeton University Press, 1983.

Lowenthal, Ira P. "Marriage is 20, Children are 21: The Cultural Construction of Conjugality and the Family in Rural Haiti." Ph.D. Dissertation: Johns Hopkins University, 1987.

Löwy, Michael. "The Historical Meaning of Christianity of Liberation in Latin America." In Coloniality at Large: Latin America and the Postcolonial Debate, co-edited by Mabel Moraña, Enrique Dussel, and Carlos A. Jáuregui, 335-49. Durham: Duke University Press, 2008. 
Lubin, André. "L'Importance d'une competitivité des exportations haïtiennes dans le contexte actuel de crise de devises." BRH magazine (June 1991): 6195.

Lubove, Roy. The Progressives and the Slums. Pittsburgh: University of Pittsburgh Press, 1962.

- The Professional Altruist: The Emergence of Social Work as a Career, 1880-1910. Cambridge: Harvard University Press, 1965.

Luccarelli, Mark. Lewis Mumford and the Ecological Region: The Politics of Planning. New York: Guilford Press, 1995.

Lucien, Georges Eddy. Modernisation et centralisation. Port-au-Prince. Editions de l'Université d'Etat d'Haïti, 2013.

_. Une modernisation manquée: Port-au-Prince, 1915-1956. 2 vols. Port-auPrince: Editions de l'Université d'Etat d'Haïti, 2013.

Lundahl, Mats. Peasants and Poverty: A Study of Haiti. New York: St. Martin's Press, 1979.

_. Politics or Markets? Essays on Haitian Underdevelopment. New York: Routledge, 1992.

_. The Political Economy of Disaster: Destitution, Plunder and Earthquake in Haiti. New York: Routledge, 2013.

MacKaye, Benton. The New Exploration: A Philosophy of Regional Planning. Urbana: University of Illinois Press, 1962. Originally published in 1928.

_. "Tennessee—Seed of a National Plan." Survey Graphic 22, no. 5 (May 1933): 251-54.

Malloy, James, ed. Authoritarianism and Corporatism in Latin America. Pittsburgh: University of Pittsburgh Press, 1976.

Malthus, Thomas. An Essay on the Principle of Population. New York: Oxford University Press, 2008. Originally published in 1798.

Manigat, Charles, Claude Moïse, and Emile Olivier. Haiti: quel développement? Montréal: Collectif Paroles, 1975.

Manigat, Leslie. "La substitution de la prépondérance américaine à la prépondérance française en Haïti au début du XXe siècle." Revue d'histoire moderne et contemporaine 14, no. 4 (October-December 1967): 321-55. 
_. D'un Duvalier à l'autre: l'itinéraire d'un fascism de sous-développement. Paris: Technique du Livre, 1971.

Mangonès, Albert. "Dans la chair et dans le sang." Reflets d'Haïti 1, no. 5 (29 October 1955).

__. "La ville que l'on mérite," Reflets d'Haïti 1, no. 4 (22 October 1955).

__ "Dans la cité vacarme." Reflets d'Haïti 1, no. 11 (10 December 1955).

Mannheim, Karl. Ideology and Utopia. In The Collected Works of Karl Mannheim, co-edited by Louis Wirth and Bryan S. Turner, vol. 1. New York:

Routledge, 2003. Originally published in 1936.

Manuel, Frank Edward and Fritzie P. Utopian Thought in the Western World. Cambridge: Belknap Press, 1979.

Marx, Karl. Capital: A Critique of Political Economy, translated by Ben Fowkes. New York: Penguin, 2004. Originally published in 1867.

Marx, Leo. The Machine in the Garden: Technology and the Pastoral Ideal in America. New York: Oxford University Press, 2000. Originally published in 1964.

Masey, Jack and Conway Lloyd Morgan. Cold War Confrontations: US Exhibitions and Their Role in the Cultural Cold War. Baden: Lars Müller Publishers, 2008.

Maternowska, M. Catherine. Reproducing Inequalities: Poverty and the Politics of Population in Haiti. New Brunswick: Rutgers University Press, 2006.

May, Elaine Tyler. Homeward Bound: American Families in the Cold War Era. New York: Basic Books, 1988.

Mazower, Mark. No Enchanted Palace: The End of Empire and the Ideological Origins of the United Nations. Princeton: Princeton University Press, 2009.

McBride, David. Missions for Science: US Technology and Medicine in America's African World. New Brunswick: Rutgers University Press, 2002.

McGirr, Lisa. Suburban Warriors: The Origins of the New American Right. Princeton: Princeton University Press, 2001.

McMahon, Robert J., ed. The Cold War in the Third World. New York: Oxford University Press, 2013.

Meacham, Standish. Regaining Paradise: Englishness and the Early Garden City Movement. New Haven: Yale University Press, 1999. 
Meehan, Richard L. Getting Sued and Other Tales of the Engineering Life. Cambridge: MIT Press, 1981.

Meller, Helen. Patrick Geddes: Social Evolutionist and City Planner. New York: Routledge, 1990.

Méndez, Eugenio Fernández. Le primitivisme haïtien. Port-au-Prince: Galerie G.S. Nader, 1972.

Metayer, Guy. "The Influence of Corporate Interests on USAID's Development Agenda: The Case of Haiti." Ph.D. Dissertation: Florida International University, 2012.

Métellus, Champagne. La doctrine cooperative. Port-au-Prince: N.p., 1948.

Métellus, Jean. Haïti, une nation pathétique. Paris: Editions Denoël, 1987.

Métraux, Alfred. "Médecine et Vaudou en Haïti." Acta Tropica 10, no. 1 (1953): 28-68.

_. "Cooperative Labor Groups in Haiti." In Peoples and Cultures of the Caribbean, edited by Michael M. Horowitz. Garden City: Natural History Press, 1971.

Miles, Malcolm. Urban Utopias: The Built and Social Architectures of Alternative Settlements. New York: Routledge, 2008.

Milkis, Sidney M., ed. The Great Society and the High Tide of Liberalism. Amherst: University of Massachusetts Press, 2005.

Mintz, Sidney. "The Employment of Capital by Market Women in Haiti." In Capital Saving and Credit in Peasant Societies, co-edited by Raymond Firth and Basil S. Yamey. Chicago: Aldine Publishing, 1964.

Moltmann, Jürgen. Theology of Hope, translated by Margaret Kohl. San Francisco: Harper \& Row, 1991. Originally published in 1965.

Montas, Yves (pseudonym Jean Luc). Structures économiques et lutte nationale populaire en Haïti. Montréal: Nouvelle Optique, 1974.

Mooney, Jadwiga E. Pieper and Fabio Lanza, eds. De-Centering Cold War History: Local and Global Change. New York: Routledge, 2012.

Moral, Paul. L'économie haïtienne. Port-au-Prince: Imp. de l'Etat, 1959.

—. Le paysan haïtien: étude sur la vie rurale en Haïti. Paris: G.P. Maisonneuve et Larose, 1961. 
More, Thomas. Utopia, translated by Clarence H. Miller. New Haven: Yale University Press, 2001. Originally published in 1516.

Morgan, Arthur E. The Small Community: Foundations of Community Life. New York: Harper \& Bros., 1942.

_. Edward Bellamy. New York: Columbia University Press, 1944.

_. Nowhere was Somewhere: How History Makes Utopias and How Utopias Make History. Chapel Hill: University of North Carolina Press, 1946.

_. Dams and Other Disasters. Boston: P. Sargent, 1971.

—. The Making of the TVA. Buffalo: Prometheus, 1974.

Morris, William. The Earthly Paradise. New York: Routledge, 2002. Originally published in 1870.

Mouterde, Pierre and Christophe Wargny. Apre bal tanbou lou: cinq ans de duplicité américaine en Haïti, 1991-1996. Paris: Editions Austral, 1996.

Moyn, Samuel. The Last Utopia: Human Rights in History. Cambridge: Belknap Press, 2010.

Moynihan, Daniel Patrick. Maximum Feasible Misunderstanding: Community Action in the War on Poverty. New York: The Free Press, 1969.

Muehlenbeck, Philip, ed. Religion and the Cold War: A Global Perspective. Nashville: Vanderbilt University Press, 2012.

Mumford, Lewis. The Story of Utopias. New York: Boni \& Liveright, 1922.

—. Art and Technics. New York: Columbia University Press, 1952.

- The City in History: Its Origins, Its Transformations, and Its Prospects. New York: Harcourt, Brace \& World, 1961.

Murray, Gerald F. "Women in Perdition: Ritual Fertility Control in Haiti." In Culture, Natality, and Family Planning, co-edited by John F. Marshall and Steven Polgar. Chapel Hill: Carolina Population Center, 1976.

Namphy, Henri. "Haïti: Président Henri Namphy." Journal of Caribbean Studies 6, no. 1 (1987): 75-82.

Nelson, Robert H. Economics as Religion: From Samuelson to Chicago and Beyond. University Park: Pennsylvania State University Press, 2001. 
Nérestant, Micial M. Religions et politique en Haïti, 1804-1990. Paris: Karthala, 1994.

Nesbitt, Nick. Universal Emancipation: The Haitian Revolution and the Radical Enlightenment. Charlottesville: University of Virginia Press, 2008.

Nichols, David. "Biology and Politics in Haiti." Race 13, no. 2 (1971): 203-14.

From Dessalines to Duvalier: Race, Colour and National Independence in Haiti. New Brunswick: Rutgers University Press, 1996. Originally published in 1979.

—. "Haiti: The Rise and Fall of Duvalierism." Third World Quarterly 8, no. 4 (October 1986): 1239-52.

Ninkovich, Frank A. The Diplomacy of Ideas: US Foreign Policy and Cultural Relations, 1938-1950. New York: Cambridge University Press, 1981.

Nozick, Robert. Anarchy, State, and Utopia. New York: Basic Books, 1974.

O'Donnell, Guillermo A. Modernization and Bureaucratic-Authoritarianism: Studies in South American Politics. Berkeley: University of California, Institute of International Studies, 1973.

Oldenziel, Ruth and Karin Zachmann, eds. Cold War Kitchen: Americanization, Technology, and European Users. Cambridge: MIT Press, 2009.

Oriol, Jacques, Léonce Viaud, and Michel Aubourg. Le mouvement folklorique en Haïti. Port-au-Prince: Imp. de l'Etat, 1952.

Overtveldt, Johan Van. The Chicago School. Chicago: Agate, 2007.

Packenham, Robert A. Liberal America and the Third World: Political Development Ideas in Foreign Aid and Social Science. Princeton: Princeton University Press, 1973.

Pamphile, Léon D. L'éducation en Haïti sous l'occupation américaine, 19151934. Port-au-Prince: Imp. des Antilles, 1988.

Parmar, Inderjeet. Foundations of the American Century: The Ford, Carnegie, and Rockefeller Foundations and the Rise of American Power. New York: Columbia University Press, 2012.

Parsons, Robert P. History of Haitian Medicine. New York: Paul B. Hoeber, 1930.

Parsons, Talcott. Theories of Society: Foundations of Modern Sociological Theory. New York: The Free Press, 1961. 
Patrick, Stewart. The Best Laid Plans: The Origins of American Multilateralism and the Dawn of the Cold War. Lanham: Rowman \& Littlefield, 2009.

Patterson, James T. America's Struggle against Poverty in the Twentieth Century. Cambridge: Harvard University Press, 2005. Originally published in 1994.

Paul, Edmond. Les causes de nos malheurs. Port-au-Prince: Editions Fardin, 1976. Originally published in 1882.

_. CEuvres posthumes. 2 vols. Paris: Chez Dunod \& P. Vicq, 1896.

—. Questions politico-économiques. 2 vols. Paris: Chez Meyrueis, 1863.

Péan, Leslie J.R. Haïti: économie politique de la corruption, vol. 3, Le saccage, 1915-1956. Paris: G.P. Maisonneuve et Larose, 2006.

- Haïti: économie politique de la corruption, vol. 4, L'ensauvagement macoute et ses consequences. Paris: G.P. Maisonneuve et Larose, 2007.

Peck, Jamie. Constructions of Neoliberal Reason. New York: Oxford University Press, 2013.

Perkins, John H. Geopolitics and the Green Revolution: Wheat, Genes, and the Cold War. New York: Oxford University Press, 1997.

Perry, Clarence. The Neighborhood Unit. In Neighborhood and Community Planning. New York: Committee on the Regional Plan of New York and Its Environs, 1929.

Pezzullo, Ralph. Plunging into Haiti: Clinton, Aristide, and the Defeat of Diplomacy. Jackson: University of Mississippi Press, 2006.

Philipsen, Dirk. The Little Big Number: How GDP Came to Rule the World and What to Do About It. Princeton: Princeton University Press, 2015.

Phillips, Sarah. This Land, This Nation: Conservation, Rural America, and the New Deal. New York: Cambridge University Press, 2007.

Phillips-Fein, Kim. Invisible Hands: The Making of the Conservative Movement from the New Deal to Reagan. New York: W.W. Norton \& Company, 2009.

Phillips-Fein, Kim and Julian E. Zelizer, eds. What's Good for Business: Business and American Politics since World War II. New York: Oxford University Press, 2012.

Phlipponneau, Michel. La vie rurale de la banlieue parisienne. Paris: Librarie Armand Colin, 1956. 
_ Géographie et action. Paris: Librarie Armand Colin, 1960.

Pierre, Gérard. The Last Captured. New York: Vantage, 2000.

Pierre, Luc-Joseph. Haïti: Vodou, lakou, esclavage et identité. Port-au-Prince: Henri Deschamps, 2001.

Pierre-Charles, Gérard. L'économie haïtienne et sa voie de développement. Paris: G.P. Maisonneuve et Larose, 1967.

—. Radiographie d'une dictature: Haïti et Duvalier. Montréal: Nouvelle Optique, 1973.

—. Haití: pese a todo la utopía. Ciudad Universitaria: Universidad Nacional Autónoma de México, 1999.

Pierre-Charles, Gérard and Suzy Castor. Echec du pouvoir olgarchique et alternative de changements en Haïti. New York: Hunter College, 1984.

Pierre-Jacques, Charles. D'Haïti à l'Afrique: itinéraire de Maurice Dartigue, un éducatteur visionnaire. Montréal: Editions Images, 2002.

Piotrow, Phyllis Tilson. World Population Crisis: The United States Response. New York: Praeger, 1973.

Piquion, Max. Pérennité. Port-au-Prince: N.p., 1971.

Plummer, Brenda Gayle. Haiti and the Great Powers, 1902-1915. Baton Rouge: Louisiana State University Press, 1988.

Postel, Charles. The Populist Vision. New York: Oxford University Press, 2007.

Preeg, Ernest H. Haiti and the CBI: A Time of Change and Opportunity. Miami: University of Miami, Institute of Interamerican Studies, 1985.

Pressoir, Catts. Le médecine en Haïti. Port-au-Prince: Imp. Modèle, 1927.

_. "Aspects psychologiques de l'application du Point Quatre." Révue de la Société Haïtienne d'Histoire, de Géographie et de Géologie 22, no. 82 (July 1951): 44-67.

Price-Mars, Jean. La vocation de l'élite. Port-au-Prince: Presses Nationales d'Haïti, 2001. Originally published in 1919.

- So Spoke the Uncle, translated by Magdaline W. Shannon. Washington, D.C.: Three Continents Press,1983. Originally published in 1928. 
—. "Géographie humaine et education technique: discours aux étudiants de Damien." Révue de la Société Haïtienne d'Histoire, de Géographie et de Géologie 9, no. 30 (July 1938): 1-10.

Rabe, Stephen G. The Killing Zone: The United States Wages Cold War in Latin America. New York: Cambridge University Press, 2011.

Ramnarine, Devanand J. "The Political Logic of the CBI." In Imperial Power and Regional Trade: The Caribbean Basin Initiative, co-edited by Abigail B. Bakan, David Cox, and Colin Leys, 11-44. Waterloo: Wilfred Laurier University Press, 1993.

Rand, Ayn. The Virtue of Selfishness: A New Concept of Egoism. New York: Signet, 1989. Originally published in 1964.

Read, Leonard A. Castles in the Air. Irvington: Foundation for Economic Education, 1975.

Reed, James. "Public Policy on Human Reproduction and the Historian." Journal of Social History 18, no. 3 (Spring 1985): 383-98.

Reed, Lawrence W. and Leslie Delatour. Reason (July 1987): 33-35.

Rém, Marlène Thélusma. Contribution de la femme haïtienne à la construction et à la survie de son pays. Paris: L'Harmattan, 2008.

Renda, Mary A. Taking Haiti: Military Occupation and the Culture of US Imperialism, 1915-1940. Chapel Hill: University of North Carolina Press, 2001.

Rigaud, Odette M. "Les effets pratiques de la magie vaudou comme médecine rituelle." In La tradition voudoo et le voudoo haïtien: son temple, ses mystères, sa magie, edited by Milo Rigaud. Paris: Niclaus, 1953.

Rist, Gilbert. The History of Development: From Western Origins to Global Faith. London: Zed Books, 1997.

Rodgers, Daniel T. Atlantic Crossings: Social Politics in a Progressive Age. Cambridge: Belknap Press, 2000.

—. The Age of Fracture. Cambridge: Belknap Press, 2012.

Rohde, Joy. Armed with Expertise: The Militarization of American Social Research during the Cold War. Ithaca: Cornell University Press, 2013.

Ronceray, Hubert de. "La création du CHISS." Les cahiers du CHISS: revue haitienne de sciences sociales 8, no. 11 (October 1974). 
_. "Enquête sur le processus d'urbanisation à Port-au-Prince." Les cahiers du CHISS: revue haitienne de sciences sociales 8, no. 11 (October 1974).

— Sociologie du fait haïtien. Québec: Presses de l'Université de Québec, 1979.

Rose, Nikolas. "Governing 'Advanced' Liberal Democracies." In Foucault and Political Reason: Liberalism, Neo-Liberalism and Rationalities of Government, co-edited by Andrew Barry, Thomas Osborne, and Rose, 3764. Chicago: University Press of Chicago, 1996.

Rosenberg, Emily S. Spreading the American Dream: American Economic and Cultural Expansion, 1890-1945. New York: Hill \& Wang, 1982.

Rostow, Walt W. The Stages of Economic Growth: A Non-Communist Manifesto. New York: Cambridge University Press, 1960.

Rotberg, Robert I. with Christopher K. Clague. Haiti: The Politics of Squalor. Boston: Houghton Mifflin, 1971.

Roumain, Jacques. Masters of the Dew, translated by Langston Hughes and Mercer Cook. Oxford: Heinemann, 1978. Originally published in 1944.

Roumain, J. B., ed. La stratégie du développement national et dimension culturelle. Port-au-Prince: Imp. M. Rodriguez, 1982.

Rouzier, Daniel-Gérard. Le pouvoir des idées. Port-au-Prince: Communication Plus, 2002.

Rouzier, Marilise. La médecine traditionnelle familiale en Haïti. Port-au-Prince: Editions de l'Université d'Etat d'Haïti, 2008.

Rouzier, Philippe. En deux ans comme en deux siècles. Montreal: CIDIHCA, 1989.

Rowland, Christopher. "The Theology of Liberation." In The Cambridge Companion to Liberation Theology, edited by Rowland, 1-16. New York: Cambridge University Press, 2007.

Rowney, Don K. Transition to Technocracy: The Structural Origins of the Soviet Administrative State. Ithaca: Cornell University Press, 1989.

Saint-Gérard, Yves Haïti: l'enfer au paradis. Mal développement et troubles de l'identité culturelle. Toulouse: Editions Eché, 1984. 
Salignon, Pierre. "Haïti, république des ONG: l'empire humanitaire en question." In Haïti aujourd'hui, Haïti demain: regards croisés, co-edited by Andrea Martinez, Peirre Beaudet, and Stephen Baranyi, 185-97. Ottawa: Presses de l'Université d'Ottawa, 2011.

San Miguel, Pedro L. The Imagined Island: History, Identity, and Utopia in Hispaniola. Chapel Hill: University of North Carolina Press, 2005.

Sanders, Grace Louise. “La Voix des Femmes: Haitian Women's Rights, National Politics and Black Activism in Port-au-Prince and Montreal, 1934-1986." Ph.D. Dissertation: University of Michigan, Ann Arbor, 2013.

Schaffer, Daniel. "Garden Cities: The Tennessee Transplant." In Town and Country Planning, no. 53 (1984): 316-18.

Schmidt, Hans The United States Occupation of Haiti, 1915-1934. New Brunswick: Rutgers University Press, 1995.

Schuller, Mark. Killing with Kindness: Haiti, International Aid, and NGOs. New Brunswick: Rutgers University Press, 2012.

Schwartz, Timothy T. "'Children are the Wealth of the Poor:' High Fertility and the Organization of Labor in the Rural Economy of Jean Rabel, Haiti." Ph.D. Dissertation: University of Florida, 2000.

—. Fewer Men, More Babies: Sex, Family, and Fertility in Haiti. Latham: Lexington Books, 2009.

Schwartz, William B. Life without Disease: The Pursuit of Medical Utopia. Berkeley: University of California Press, 1998.

Scott, James C. Seeing Like a State: How Certain Schemes to Improve the Human Condition Have Failed New Haven: Yale University Press, 1998.

—. "High Modernist Social Engineering: The Case of the TVA." In Experiencing the State, co-edited by Lloyd I. Rudolph and John Kurt Jacobson. Delhi: Oxford University Press, 2007.

Segal, Howard P. "Leo Marx's 'Middle Landscape:' A Critique, a Revision, and an Appreciation." Reviews in American History 5, no. 1 (March 1977): 137-50.

—. Technological Utopianism in American Culture. Chicago: University of Chicago Press, 1985.

Sénéchal, Jean-François. Le mythe révolutionnaire duvaliériste. Montréal: CIDIHCA, 2006. 
Shaanan, Joseph. Economic Freedom and the American Dream. New York: Palgrave Macmillan, 2010.

Shamsie, Yasmine. "The Economic Dimension of Peacebuilding." In Haiti: Hope for a Fragile State, co-edited by Shamsie and Andrew S. Thompson, 3750. Waterloo: Wilfrid Laurier University Press, 2006.

Shannon, Magdaline W. Jean Price-Mars, the Haitian Elite and the American Occupation, 1915-1935. New York: St. Martin's Press, 1996.

Sharpless, John. "Population Science, Private Foundations, and Development Aid: The Transformation of Demographic Knowledge in the United States, 1945-1965." In International Development and the Social Sciences, coedited by Frederick Cooper and Randall Packard, 176-202. Berkeley: University of California Press, 1997.

Shklar, Judith N. After Utopia: The Decline of Political Faith. Princeton: Princeton University Press, 1957.

Shultz, George P. Turmoil and Triumph: My Years as Secretary of State. New York: Charles Scribner's Sons, 1993.

Sibley, Mulford Q. Technology and Utopia Thought. Minneapolis: Burgess, 1971.

Siebers, Tobin. Cold War Criticism and the Politics of Skepticism. New York: Oxford University Press, 1993.

Smith, Jennie M. When the Hands Are Many: Community Organization and Social Change in Rural Haiti. Chapel Hill: University of North Carolina Press, 2001.

Smith, Mark A. The Right Talk: How Conservatives Transformed the Great Society into the Economic Society. Princeton: Princeton University Press, 2007.

Smith, Matthew J. Red and Black in Haiti: Radicalism, Conflict, and Political Change, 1934-1957. Chapel Hill: University of North Carolina Press, 2009.

Smith, Tony. "New Bottles for New Wine: A Pericentric Framework for the Study of the Cold War." Diplomatic History 24, no. 1 (Fall 2000): 567-91.

Smyth, William Henry. Technocracy. Berkeley: N.p., 1921.

Solovey, Mark. Shaky Foundations: The Politics-Patronage-Social Science Nexus in Cold War America. New Brunswick: Rutgers University Press, 2013. 
Solovey, Mark and Hamilton Cravens, eds. Cold War Social Science: Knowledge Production, Liberal Democracy, and Human Nature. New York: Palgrave Macmillan, 2012.

Soukar, Michel. Seize ans de lutte pour un pays normal. Port-au-Prince: Editions SCOLHA, 1987.

Spann, Edward K. Designing Modern America: The Regional Planning Association of America and Its Members. Columbus: Ohio State University Press, 1996.

Sprague, Jeb. Paramilitarism and the Assault on Democracy in Haiti. New York: Monthly Review Press, 2012.

St. Méry, Moreau de. Description topographique, phusique, civile, politique et historique de la parte française de l'isle Saint-Dominque, 2 vols. Paris: Chez Dupont, 1798.

Statler, Kathryn C. and Andrew L. Johns, eds. The Eisenhower Administration, the Third World, and the Globalization of the Cold War. Lanham: Rowman \& Littlefield, 2006.

Stern, Steve. "The Decentered Center and the Expansionist Periphery: The Paradoxes of the Foreign-Local Encounter." In Close Encounters of Empire: Writing the Cultural History of US-Latin America Relations, coedited by Gilbert M. Joseph, Catherine C. Legrand, and Ricardo D. Salvatore, 47-68. Durham: Duke University Press, 1998.

Stigler, George J. The Theory of Price. New York: Macmillan, 1966.

Stoner, K. Lynn. From the House to the Streets: The Cuban Woman's Movement for Legal Reform, 1898-1940. Durham: Duke University Press, 1991.

Stycos, J. Mayone. "Experiments in Social Change: The Caribbean Fertility Studies." In Research in Family Planning, edited by Clyde V. Kiser. Princeton: Princeton University Press, 1962.

Suvin, Darko. Defined by a Hollow: Essays on Utopia, Science Fiction and Political Epistemology. New York: Peter Lang, 2010.

Szreter, Simon. "The Idea of Demographic Transition and the Study of Fertility: A Critical Intellectual History." Population and Development Review 19, no. 4 (December 1993): 659-701.

Tally, Jr., Robert T. Utopia in the Age of Globalization: Space, Representation, and the World-System. New York: Palgrave Macmillan, 2013. 
Théus, Beguens ONG et pauvreté en Haïti. Port-au-Prince: Editions Mémoire, 2011.

Tillich, Paul. "Critique and Justification of Utopia." In Utopias and Utopian Thought, edited by Frank E. Manuel. Cambridge: Riverside Press, 1966.

Toussaint, Hérold. L'utopie révolutionnaire en Haïti: autour de Jacques Roumain. Port-au-Prince: Presses Nationales d'Haïti, 2012.

Trahair, Richard C.S., ed. Utopias and Utopians: A Historical Dictionary. Westport: Greenwood Press, 1999.

Tremblay, Johanne. Mères, pouvoir et santé en Haïti. Paris: Karthala, 1995.

Trouillot, Michel-Rolph. Haiti: State Against Nation. The Origins and Legacy of Duvalierism. New York: Monthly Review Press, 1990.

Tugwell, Rexford G. The Brains Trust. New York: Viking, 1968.

Turner, Denys. "Marxism, Liberation Theology and the Way of Negation." In The Cambridge Companion to Liberation Theology, edited by Christopher Rowland, 229-47. New York: Cambridge University Press, 2007.

Turner, John. "Uncontrolled Urban Settlement: Problems and Policies." In The City in Newly Developing Countries, edited by Gerald Breese, 508-12. Englewood Cliffs: Prentice-Hall, 1969.

Turnier, Alain. Les États-Unis et le marché haïtien. Montréal: Imp. Saint-Joseph, 1955.

Valdés, Juan Gabriel. Pinochet's Economists: The Chicago School in Chile. New York: Cambridge University Press, 1995.

Vallès, Marie-Thérèse. Les ideologies coopérativistes et leur applicabilité en Haiti. Paris: G.P. Maisonneuve et Larose, 1967.

Vegso, Roland. The Naked Communist: Cold War Modernism and the Politics of Popular Culture. New York: Fordham University Press, 2012.

Von Eschen, Penny. Satchmo Blows Up the World: Jazz Ambassadors Play the Cold War. Cambridge: Harvard University Press, 2006.

Von Tunzelmann, Alex. Red Heat: Conspiracy, Murder, and the Cold War in the Caribbean. New York: Henry Holt, 2011.

Wagnleitner, Reinhold. Coca-Colonization and the Cold War: The Cultural Mission of the United States in Austria After the Second World War. Chapel Hill: University of North Carolina Press, 1994. 
Wallerstein, Immanuel. The Modern World-System, vol. 3, The Second Era of Great Expansion of the Capitalist World-Economy, 1730s-1840s.

Berkeley: University of California Press, 2011. Originally published in 1989.

- Utopistics: Historical Choices of the Twenty-First Century. New York: The Free Press, 1998.

Wargny, Christophe. Haïti n'existe pas: 1804-2004, deux cents ans de solitude. Paris: Editions Autrement, 2004.

Weaver, Karol K. Medical Revolutionaries: The Enslaved Healers of EighteenthCentury Saint Domingue. Urbana: University of Illinois Press, 2006.

Wegner, Phillip E. Imaginary Communities: Utopia, the Nation, and the Spatial Histories of Modernity. Berkeley: University of California Press, 2002.

Weiler, Michael and W. Barnett Pearce, eds. Reagan and Public Discourse in America. Tuscaloosa: University of Alabama Press, 1992.

Weiss, Thomas G. and Sam Daws, eds. The Oxford Handbook on the United Nations. New York: Oxford University Press, 2007.

Weisskoff, Richard. Factories and Food Stamps: The Puerto Rico Model of Development. Baltimore: Johns Hopkins University Press, 1985.

Westad, Odd Arne. The Global Cold War: Third World Interventions and the Making of Our Times. New York: Cambridge University Press, 2005.

Williams, Amrys O. "Cultivating Modern America: 4-H Clubs and Rural Development in the Twentieth Century." Ph.D. Dissertation: University of Wisconsin, Madison: 2012.

Williamson, Charles T. The US Naval Mission to Haiti, 1959-1963. Annapolis: Naval Institute Press, 1999.

Wilentz, Amy. The Rainy Season: Haiti since Duvalier. New York: Simon \& Schuster, 1989.

Williams, William Appleman. The Tragedy of American Diplomacy. New York: W.W. Norton \& Company, 1962. Originally published in 1959.

Wilson, John F., Anthony Webster, and Rachael Vorberg-Rugh. Building Cooperation: A Business History of the Co-Operative Group, 1863-2013. New York: Oxford University Press, 2013.

Wirkus, Faustin E. The White King of La Gonave. Garden City: Doubleday, 1931. 
Wood, Bryce. The Making of the Good Neighbor Policy. New York: Columbia University Press, 1961.

Yurchak, Alexei. Everything Was Forever, Until it Was No More: The Last Soviet Generation. Princeton: Princeton University Press, 2005.

Zarefsky, David. President Johnson's War on Poverty: Rhetoric and History. Tuscaloosa: University of Alabama Press, 1986.

Zipp, Samuel. Manhattan Projects: The Rise and Fall of Urban Renewal in Cold War New York. New York: Oxford University Press, 2010. 
ADAM M. SILIVA

2015-2016 Dissertation Writing Fellowship

Florida International University, University Graduate School Miami, Florida

2014-2015 Green Family Fellowship in Latin American Studies

Green Family Foundation

Miami, Florida

2012-2015 Dissertation Evidence Acquisition Fellowship

Florida International Univesity, University Graduate School

Miami, Florida

2010-2014 Student Assistant

Digital Library of the Caribbean

Miami, Florida

2009-2016 Doctoral Candidate, History

Florida International University

Miami, Florida

2009-2010 Foreign Language Areas Studies Fellow

Department of Education, Florida International University

Center for Latin American and Caribbean Studies

$2008 \quad$ Haitian Creole Summer Institute

Florida International University

Miami, Florida

2007-2012 Teaching Assistant

Florida International University

Miami, Florida

2007-2009 M.A., History

Florida International University

Miami, Florida

2003-2007 B.A., History (Major), French (Minor)

Framingham State University

Framingham, Massachusetts 


\section{PUBLICATIONS AND PRESENTATIONS}

Silvia, Adam M. Diederich and the Americas: The Story In-Between the Lines. Miami: Florida International University Libraries, 2016.

- The Bernard Diederich Collection Finding Aid. Miami: Florida International University Libraries, 2016.

_ "The History of Eugenics in Haiti." In "The Living Archives on Eugenics in Western Canada," http://www.eugenicsarchive.ca/discover/word. Alberta: Social Science and Humanities Research Council of Canada, 2015.

Accilien, Cécile, Kiran Jayaram, Régine Jean-Charles, and Adam M. Silvia. "Funding Haitian Studies." Presentation at the annual meeting of the Haitian Studies Association, Université de Montréal, Québec, Canada, October 22, 2015.

Silvia, Adam M. "New Homes to Raise a Nation: The United Nations and the 'Master Plan' to Renovate Haiti's Capital City." Paper presented at the annual Conference on Latin American History, New York, New York. January 2, 2015.

—. "Modern Mothers for Third World Nations: Population Control, Western Medical Imperialism, and Cold War Politics in Haiti." Social History of Medicine 27, no. 2 (May 2014): 260-80.

Silvia, Adam M., ed. "Haiti: An Island Luminous," http://islandluminous.fiu.edu. Miami: Digital Library of the Caribbean, 2014.

Silvia, Adam M. "The Bernard Diederich Collection: A Preview." Paper presented at the annual meeting of the Caribbean Studies Association, Mérida, Mexico. May 30, 2014.

_. "Electricity and Modernity in Haiti." Paper presented at the 8th Savannah Symposium, Savannah College of Art and Design, Savannah, Georgia. February 7, 2013.

- Review of Haiti and the Haitian Diaspora in the Wider Caribbean, ed. Philippe Zaïcar. The Americas 68 no. 1 (July 2011): 161-62.

- "The Day the Banks Stood Still: Haiti, the US, and Monetary Policy in the 1980s." Paper presented at the annual Contemporary French and Francophone Studies Conference, Florida State University, Tallahassee, Florida. February 26, 2010.

_ "Haiti's School for Bitter Rivals: Tension Over Education Reform, 19241946." Paper presented at the annual meeting of the Haitian Studies Association, Montrouis, Haiti. November 7, 2008. 